Eric Rugraff \& Michael W. Hansen (eds.)

\title{
Multinational Corporations
}

\section{and Local Firms in \\ Emerging Economies}

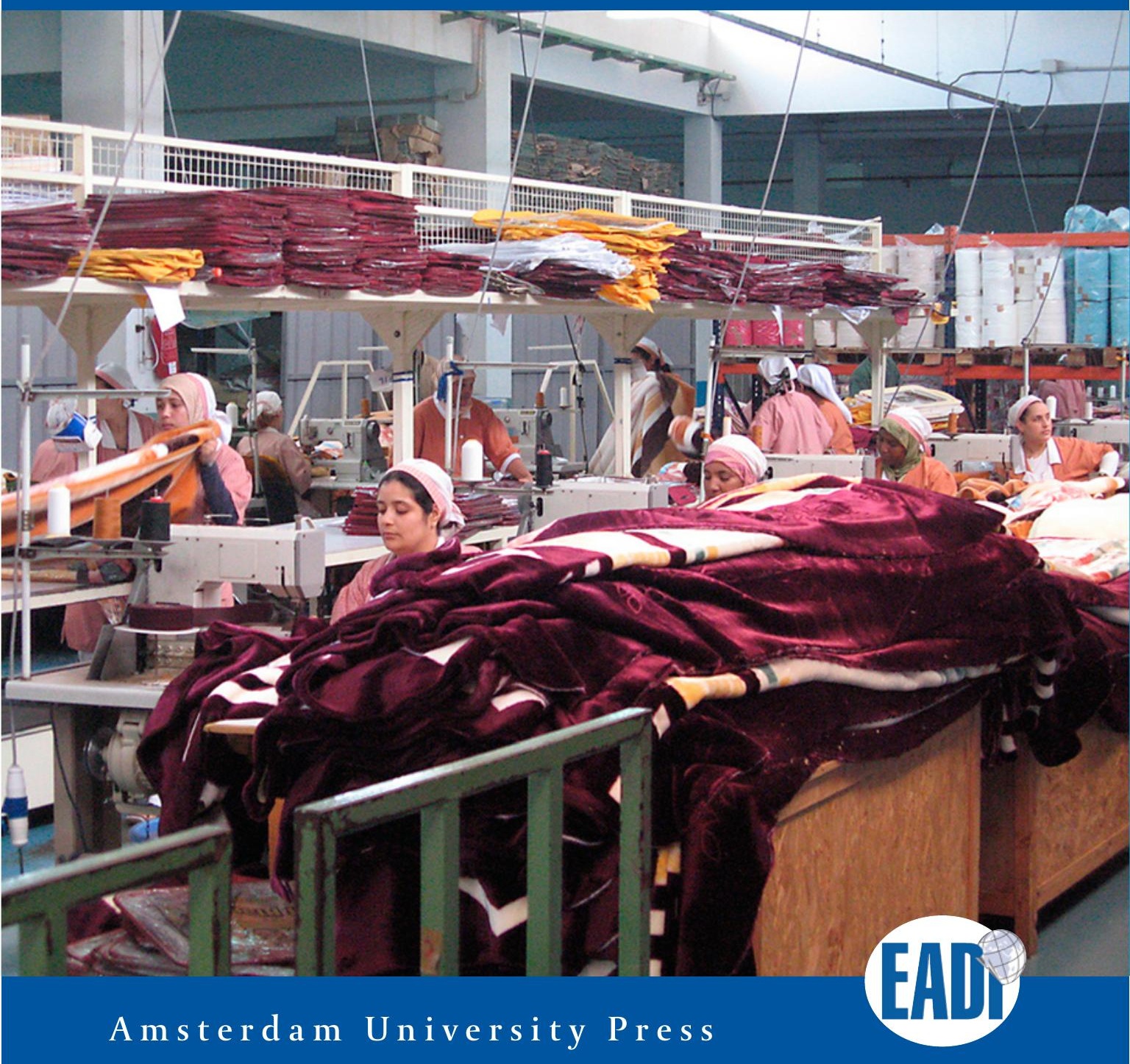


MULTINATIONAL CORPORATIONS AND LOCAL FIRMS IN EMERGING ECONOMIES 



\title{
Multinational Corporations and Local Firms in Emerging Economies
}

\author{
Edited by
}

Eric Rugraff and

Michael W. Hansen 
EADI - the European Association of Development Research and Training Institutes - is the leading professional network for development and regional studies in Europe (www.eadi.org).

Cover design: Mesika Design, Hilversum

Lay-out: V3-Services, Baarn

ISBN $\quad 9789089642943$

e-ISBN $97890485 \mathrm{I} 3864$

NUR $\quad 784 / 759$

(C) Eric Rugraff \& Michael Hansen / Amsterdam University Press, Amsterdam 20II

All rights reserved. Without limiting the rights under copyright reserved above, no part of this book may be reproduced, stored in or introduced into a retrieval system, or transmitted, in any form or by any means (electronic, mechanical, photocopying, recording or otherwise) without the written permission of both the copyright owner and the author of the book. 


\section{Table of contents}

Preface 9

\section{INTRODUCTION}

I MULTINATIONAL CORPORATIONS AND LOCAL FIRMS IN EMERGING eCONOMies: An introduction I3

Eric Rugraff and Michael W. Hansen

I.I Introduction I3

I.2 The new global context of multionational corporation-local firm relations 14

I.3 The main concepts of multinational corporation-local firm relations: Spillovers and linkages I6

I.4 The theory of multinational corporation-local firm relations 2I

I.5 Research on multinational corporation-local firm relations 24

I.6 Contributions to the book 3I

I.7 Conclusion 37

II STUdies OF SPILLOVERS AND LINKAGES BETWEEN MULTINATIONAL CORPORATIONS AND LOCAL FIRMS

2 The IMPACT OF FOREIGN DIRECT INVESTMENT IN BUSINESS SERVICES on the local economy: The case of Hungary $5 \mathrm{I}$ Magdolna Sass

2.I Introduction 5I

2.2 Review of the literature and analytical framework 54

2.3 Foreign direct investment in business services in Hungary and channels of its local impact 56

2.4 Conclusion 69 
3 Do multinational companies transfer technology to local Small and medium-Sized enterprises? The case of the Tegal METALWORKING INDUSTRY CLUSTER IN INDONESIA 75

Tulus Tambunan

3+1 Introduction 75

3.2 Multinational companies in Indonesia 76

3.3 The case of Tegal metalworking industry 79

3.4 Findings 82

3.5 Concluding remarks 93

African small and medium enterprises and the Challenges in global Value chains: The Case of Nigerian garment ENTERPRISES IOI

Osmund Osinachi Uzor

4.I Introduction IOI

4.2 The methodological limitations IO2

4.3 Overviews of literature and theoretical background IO3

4.4 Global value chains and the challenges in upgrading African small and medium enterprise garment producers 107

4.5 The capabilities of small and medium enterprises in garment producers in Aba IIo

4.6 Conclusions and recommendations II7

5 Mutual productivity spillovers and regional clusters in Eastern Europe: Some empirical evidence 123

Chiara Franco and Kornelia Kozovska

5+I Introduction 123

5.2 Foreign direct investment and spillovers: the direct effect $\quad$ I25

5.3 Foreign direct investment and spillovers: the reverse effect I28

5.4 Foreign direct investment and spillovers: the mediating factors 130

5.5 Empirical analysis $\mathbf{1 3 2}$

5.6 Results 137

5.7 Conclusion 138

Annex: Tables I45 


\section{Policies to Promote SPILlovers and linkages}

6 SCOPE AND EFFECTIVENESS OF FOREIGN DIRECT INVESTMENT POLICIES IN TRANSITION ECONOMIES I55

Črt Kostevc, Tjaša Redek and Matija Rojec

6.I Introduction I55

6.2 The scope of a foreign direct investment regime and policy in determining a country's attractiveness as investment location $\quad 156$

6.3 Economics of investment incentives 158

6.4 Issues and trends in investment incentives policies $\quad 159$

6.5 Effectiveness of investment incentives in transition countries in view of policy objectives, type and size of incentives and their delivery I6I

6.6 Overview of knowledge-transfer related investment incentives in selected transition countries $\quad 167$

6.7 Conclusions and policy suggestions $\quad$ I73

7 Policies for attracting foreign direct investment and ENHANCING ITS SPILLOVERS TO INDIGENOUS FIRMS: THE CASE OF HungARY I8I Katalin Antalóczy, Magdolna Sass and Miklós Szanyi

7.I Introduction I8I

7.2 Foreign direct investment in Hungary I8I

7.3 Foreign direct investment policies in Hungary 184

7.4 How efficient are foreign direct investment policies? Overview of the empirical literature 195

7.5 Two company case studies 196

7.6 The impact of the crisis 203

7.7 Conclusion 204

8 Policies AND institutions ON MUlTiNATIONAL CORPORATION-SMALl AND MEDIUM ENTERPRise LINKAges: The Brazilian CASE 2II

Delane Botelho and Mike Pfister

8.I Introduction 2II

8.2 Conceptual framework of business linkages 213

8.3 Supplier development programs 215

8.4 Public policies and the Brazilian effort to develop companies 217

8.5 Policy orientation for small and medium enterprises in Brazil 219

8.6 Analysis 220

8.7 Conclusion 224 
9 IS ATTRACTING FOREIGN DIRECT INVESTMENT THE ONLY ROUTE TO indUSTRIAL DEVELOPMENT IN AN ERA OF Globalization? The CASE OF the Clothing and textiles sector in South Africa 23I

Soeren Jeppesen and Justin Barnes

9.I Introduction 23I

9.2 Industrial development and policy: Theoretical positions 234

9.3 The South African case: The situation in the textiles and clothing industry 238

9.4 Government responses and policy developments 240

9.5 The mismatch between government policies and the realities in the industry: Why did the South African government follow export orientation and not pursue foreign direct investment? 247

9.6 Concluding remarks and implications for industrial policy 256 Appendixes 265

About the authors 267

INDEX 273 


\section{Preface}

It is increasingly recognized by policymakers as well as academics around the world that close direct and indirect interaction between multinational corporations (MNCs) and local firms is absolutely essential if foreign direct investment (FDI) is to have deep and lasting positive effects on host countries. Nevertheless, the issue of MNC-local firm interaction has been relatively underexplored in the academic literature until recently, where we have seen the emergence of a growing literature focusing on linkages and spillovers from FDI.

This book aims at contributing to the emerging literature on MNC-local firm interfaces by providing a number of country studies from emerging economies of the spillover and linkage effects of multinational corporations on local firms. Moreover, the book takes the issue to the policy level by sharing and evaluating policy experiences from a number of countries on efforts to promote closer interaction between MNCs and local firms. The country studies are placed within a framework for analyzing MNC-local firm interfaces that integrates insights from the spillover and linkage literature.

The book's primary market is postgraduate students and researchers in economics, business studies, international relations, political science, development studies and area studies. However, because the book has a policy orientation, development practitioners and policymakers may also find insights and analyses that may inspire efforts to enhance spillover effects of multinational corporations in emerging economies.

The book is part of the ongoing work of the Working Group on Transnational Corporations of the European Association of Development Research and Training Institutes (EADI). The idea for the book was launched at the 2008 General EADI Conference in Geneva and a call for papers was posted in the fall of 2008 . The book in hand represents a selection of the best papers responding to this call.

The book has been edited by the conveners of the EADI Working Group on Transnational Corporations Eric Rugraff and Michael W. Hansen. Eric Rugraff 
is Associate Professor in International Economics at the University of Strasbourg and researcher at the Bureau d'Economie Théorique et Appliquée (BETA) and Michael W. Hansen is Associate Professor in International Business at the Copenhagen Business School (CBS) and researcher at the Center for Business and Development Studies.

We are grateful for financial support from the EADI Secretariat.

Strasbourg and Copenhagen, September 2010

Eric Rugraff and Michael W. Hansen 


\section{Part I}

INTRODUCTION 



\title{
I Multinational corporations and local firms in emerging economies
}

\author{
An introduction
}

Eric Rugraff and Michael W. Hansen

\section{I+I Introduction}

One of the most heated issues within current development debates relates to the role played by multinational corporations (MNCs) in economic development. On the one hand, MNCs may help emerging economies ${ }^{1}$ in the modernization of their economies and industries by transferring technology, know-how and skills, by providing access to export markets, by intensifying competition, or by making available goods and services that are better and/or cheaper than those offered by local producers (De Mello, 1999; UNCTAD, 1999; JBIC Institute, 2002). On the other hand, beneficial effects are not given and MNCs may stifle economic development by locking in host economies in low value-added activities and by crowding out local investments and jobs. Furthermore, anti-competitive practices of MNCs may reduce consumer welfare and MNCs may help build consumption patterns that are unsuited for host countries (Caves, 1996; Buckley and Ghaury, 2002; Cypher and Diez, 2004).

As noted by numerous authors, at the end of the day it must be concluded that MNCs obviously are both 'boon' and 'bane' for emerging economies (Caves, 1996; Nunnenkamp, 2004; Dicken, 2004; Görg and Greenaway, 2004; Endewick, 2005) and therefore the key issue is when foreign direct investment (FDI) by MNCs is beneficial to economic development and when it is not. In this regard, the literature has pointed out numerous factors that condition FDI impacts, such as government policies (Dunning, 1997), MNC investment motives (Endewick, 2005), MNC entry strategies (Görg and Greenaway, 2004), absorptive capacity of local industry (Narula and Lall, 2004), or the extent to which MNCs link up to local firms and industries (Altenburg, 2000; Giroud and Scott-Kennel, 2006).

One of the key issues related to MNCs' role in economic development is the way in which MNCs interact with local firms and industries. This issue is increasingly pivotal as $\mathrm{MNCs}^{\prime}$ role in organizing global economic activity grows 
and as private sector development becomes a key development priority in more and more countries. In this situation, it is crucial to ask whether and how MNCs contribute to the development of the local private sector. Are MNCs inciting local industries to become more effective by exposing them to competition and demonstrating advanced production methods, or are they on the contrary using their market power to crowd out local firms? Are MNCs building broad local networks of related and supporting industries in host countries or are they rather creating enclave economies with few local linkages? And are MNCs investing in upgrading competencies of local firms and industries or are they on the contrary keeping local firms in low value adding routine functions and activities? In short, would indigenous industries and firms be better or worse off without the entry of MNCs?

The aim of this book is to provide insights into the nature and dynamics of MNC-local firm interaction in the new global context of private sector driven economic development and the growing importance of MNC activity in emerging economies. This will be done by offering evidence from a variety of emerging economies on MNC-local firm interaction and on how governments have dealt with this issue. It is hoped that this book will assist in developing a better understanding of the complexities and variations in MNC-local firm interaction, and thereby contribute to better informed policy intervention on MNCs.

In the following we will describe what we have called 'the new global context' of the MNC-local firm relationship. We will then move on to provide a conceptual and theoretical framework for the book, as well as a review of the extant literature on MNC-local firm interaction. Finally, we will position the contributions of the book within the existing literature and assess how we see these studies contributing to the literature.

\section{I.2 The new global context of multinational corporation-local firm relations}

\subsubsection{The changing map of foreign direct investment}

One of the most striking aspects of FDI in recent decades is the growing FDI in emerging economies, rising from a level of $20-30 \%$ of all FDI flows in the early I 990 s to $30-40 \%$ in the mid 2000 s. While the financial crisis has significantly reduced the absolute amount of FDI, in emerging economies it has continued to rise relative to total FDI, as growth in these countries is relatively high and as the need of Western MNCs to streamline their cost structures and access resources continue to drive FDI in these countries. Indeed, it is predicted that FDI flows to emerging economies will exceed those of developed countries by the early 2010 (UNCTAD, 
2009). The vast majority of FDI in emerging economies is concentrated in a small group of Asian countries (in particular China) and in rapidly growing Eastern European countries. However, while the least developed countries receive negligible flows of FDI, these flows can be just as significant if measured in relation to the size of their economies (Nunnenkamp, 2004; UNCTAD, 2009).

The composition of FDI in emerging economies has changed significantly in recent years. Where FDI in these countries traditionally was concentrated in extractive industries or was market-seeking in relation to intermediary and consumer goods, there has recently been a surge in services FDI. Moreover, we have witnessed growing efficiency and strategic asset-seeking investments, in particular in some of the more advanced Asian countries. Much of the FDI is in the form of acquisitions, an indication that emerging economies are building advanced local industries that are attractive investment targets for MNCs. Finally, the source of FDI has changed; the share of FDI originating from emerging economies themselves has risen from approximately I0\% of global FDI around 2000, to more than $20 \%$ by the end of the decade (UNCTAD, 2009).

The changing map of FDI is driven by a number of developments, first among them the more FDI-conducive environments in many parts of the world with reduced formal and informal barriers to investment (Rugraff, 2008); larger, rapidly growing, and increasingly sophisticated markets; improved infrastructures; improved skill bases and education levels; and the development of vibrant local supply industries capable of supporting foreign investors with goods and services (see for example Kapur et al., 200I; Jiang et al., 2005). Simultaneously, MNCs are making fundamental changes to their strategies: they are increasingly disintegrating their value chains and outsourcing more and more activities globally (Porter, 1986; Sturgeon and Lester, 2003). Moreover, MNCs are changing their competitive horizons from mainly national and regional arenas to increasingly global arenas. The changing strategies of MNCs match the improved conditions of emerging economies well and consequently, we see a widening and deepening of MNC activity in such countries. All this takes place against the backdrop of advances in communication technology and decreases in transportation costs, which reduce the importance of geographical proximity (Dicken, 2003).

\subsubsection{Implications for emerging economies}

The changing map of FDI has huge positive and negative implications for industrial and more broadly, economic development. Apart from offering an injection of scarce investment capital, FDI comes with a package of technology, skills, connections and market opportunities. Moreover, FDI may introduce better and cheaper products and sharpen competition, thereby improving consumer welfare. 
The growing sophistication of MNC activities enhances the potential impact of MNCs on host countries' skills and technology base. On the other hand, foreign investors' market power may suppress competition and subject whole sectors of the host countries to the strategies of MNCs (Gereffi, 1999). As MNCs are looking for increasingly advanced and reliable types of assets in the countries they are investing in, and as the number of locations offering favorable conditions is growing, competition for FDI increases and the danger of competitive bidding and deepened divisions grows between countries catching up and falling behind (Dunning and Narula, 2004).

FDI is not least a two-edged sword for local firms and industries in emerging economies; on the one hand, the arrival of foreign firms introduces discomforting and sometimes unfair competition, not only in product markets but also in labor and capital markets. Furthermore, MNCs may use their bargaining power to get privileges and exemptions from governments not extended to local firms. On the other hand, if local firms succeed in linking up to the foreign investors, FDI may offer vast opportunities for expanding activities as suppliers and subcontractors to the MNCs. Moreover, the local firms may learn from the collaboration, for example learn about more advanced standards and organizations, and thus upgrade to more advanced activities. With regard to firms unrelated to the MNCs, MNCs may demonstrate new production technologies, marketing practices and managerial approaches that may be adopted by the local firms, and former employees of MNCs may inject dynamism into local firms if hired there. Finally, MNCs may use their financial and organizational strength to push for further development of the commercial infrastructure and regulation in the host country, something that also may benefit local firms.

This book seeks to improve our understanding of the positive and negative aspects of MNC-local firm relations, the conditions under which they occur, and how governments, through various policy measures, can promote positive MNClocal firm interaction.

\section{I.3 The main concepts of multinational corporation-local firm relations: Spillovers and linkages}

The literature on MNC-local firm interaction essentially revolves around two concepts, spillovers and linkages. The term 'spillovers' denotes the impact or effect of an interaction between the MNC and the local firm and the term 'linkages' denotes the organizational modality of the interaction. We will clarify these concepts and their relation in the following sections. 


\subsubsection{Spillovers}

The initial theoretical and empirical literature on effects of FDI focused on the direct impacts of the multinationals such as additional capital brought into the country, the creation of jobs, the effect on the balance of payment, and so on (MacDougall, 1960). Another part of the FDI impact literature that took on a real importance at the beginning of the 1990s (UNCTAD, 1992), tried to evaluate the macroeconomic effect of FDI on the growth rate of developing countries, some studies detecting positive impacts (see for example Borensztein et al., 1998; De Mello, 1999; Chan, 2000) other studies failing to detect such effects (Hein, 1992; Singh, 1998). One of the most fecund avenues in the FDI study of impacts however, was opened by the seminal work of Caves (1974), who considered that spillover effects of MNCs on local firms were the crux of the matter. Since then, the research on FDI effects has increasingly acknowledged that technological, organizational and managerial spillovers on local firms probably represent the most influential role of MNCs in host country development.

Spillovers from FDI are essentially positive externalities from the presence of MNCs on the local economy (Blomström and Kokko, 1998). Spillovers derive from the fact that a firm that internationalizes possesses an intrinsic advantage over firms in the host country (Dunning, 1988). In foreign countries, a MNC is particularly incited to secure its knowledge, management and information assets due to the fact that its competitive advantage is directly linked to its capacity to limit diffusion to local competitors. But at the same time, a foreign investor is not able to, or necessarily interested in, totally hindering its advantages from leaking out to the local environment as spillovers. Hence, spillovers take place when multinationals are unable to, or uninterested in, extracting the full value of the resulting productivity increase of their activity in the host economy. Since a MNC often is profoundly different from a (non-internationalized) local firm in terms of technology, capital, organizational and managerial capabilities, and international market access, there is a potential for significant spillovers on the local economy and local firms.

The spillover can happen through indirect means (for example spillovers on local competitors) or it can happen through direct means (for example spillovers through subcontracting, outsourcing, licensing, franchising, and so on).

The literature typically identifies two main catalyst effects of a multinational on local firms: horizontal spillovers on local competitors and vertical spillovers on indigenous suppliers, distributors and customers linked to foreign-owned firms in the value chain.

Spillovers may take the form of knowledge spillovers or pecuniary spillovers. Knowledge externalities represent technology and know-how that may spill over 
from multinationals to local firms. Pecuniary spillovers take the form of a rent for the local industry: multinationals' activity improves the quality of the local production that is only partially incorporated in the prices of the products and services delivered by the multinational. The rent may also result from an additional demand addressed to the local intermediate goods industry that enables the local industry to produce with increasing return to scale and to deliver cheaper products and services to local buyers.

One may consider five main situations regarding the global effect of the multinationals on the local firms (Table I.I):

Table 1.1 Spillovers (+) and negative externalities (-) of multinationals on local firms

\begin{tabular}{llll}
\hline & Vertical effect & Horizontal effect & Total effect \\
\hline Case 1 & + & + & + \\
\hline Case 2 & + & 0 & + \\
\hline Case 3 & - & - & - \\
\hline Case 4 & 0 & 0 & 0 \\
\hline Case 5 & + & - & $?$ \\
\hline
\end{tabular}

Note: $0=$ insignificant effect; $?=$ undetermined effect

Case I is the best option for the local industry. MNCs source locally and have a catalyst effect on the local intermediate goods industry. The entry of multinationals also has a positive impact on the local rivals who have increased their performances by imitating the multinationals and by reacting to the competitive pressure of the newcomers. A positive horizontal effect may result from a moderate technological gap between multinationals and local firms, fostering imitation and competitive reaction (Kokko et al., 1996).

In case 2, the total impact remains positive, despite the absence of horizontal spillovers. Absence of horizontal spillovers may be due to differences in the sectoral specialization between foreign and local firms for example when multinationals invest in new sectors where there are no local firms yet. It may also be linked to the export-orientation of the multinationals, which do not reduce the local market share of the local firms (Blyde et al., 2004).

In case 3 , multinationals have a negative vertical effect and a negative horizontal effect. The latter may result from the difference in efficiency between the foreign and the indigenous actors that jeopardizes the development of the local industry and crowds out local rivals. Inward-looking multinationals that have invested in a country to serve the local market may reduce the number of local firms and/or oblige them to specialize in low value-added products and a production based on 
weak economies of scale. A multinational may also displace pre-existing connections between local firms and their suppliers and have negative vertical effects. Multinationals have negative effects when they crowd out local rivals which were used to purchasing more abundantly from local suppliers than multinationals do.

In case 4 , multinationals have only very few forward relationships with the local customers and very limited backward relationships with local suppliers: the multinational reveals 'enclave' behavior. This kind of behavior may emerge especially in backward countries in which the human skills and the technological level are low and the quality of institutions is weak. The absence of horizontal effects may be due to the dominant position that has been granted to a foreign firm (monopoly) or to a handful of foreign firms (oligopoly) in the privatization process of the local industry.

Case 5 is a classical case of the spillover literature in developing countries and transition economies. Although the multinationals crowd out local rivals in the final goods industry thanks to their ownership advantages, the net gain for the local suppliers and/or for the local customers is positive.

\subsubsection{Linkages}

Local firms may benefit from spillovers from MNCs despite limited direct interaction with the MNCs, for example through competition and demonstration. But many authors hold that direct interaction - typically labeled linkages - will facilitate spillovers. Thus, a long tradition dating back to Hirschman's seminal work on the role of linkages in economic development (1958) has argued that lack of linkages in the developing economy leads to lack of industrial development. While Hirschman's argument did not specifically relate to foreign firms, it has inspired much of the later research on MNCs and linkages. The general assumption of this research is that from a development perspective, linkages between MNCs and local firms are better than no linkages, and the more and the deeper linkages are, the better it is for the host economy (Altenburg, 2000; Scott-Kennel and Enderwick, 2005; Hansen et al., 2006).

While some authors prefer a broad definition of MNC linkages that encompass transactions between MNCs and local firms as well as non-business institutions and organizations (Altenburg, 2000), we will here focus on linkages between MNCs and local firms. Thus we define linkages as interfirm transactions that go beyond arm's length, one-off transactions and involve some level of collaboration between the transacting parties (Hansen et al., 2009). Linkages can be long term (for example a long-term strategic partnership on $\mathrm{R} \& \mathrm{D}$ ) or they can be short term (for instance an intermittent purchase on contract). They can be equity-based (a joint venture between the MNC and a local firm) or they 
can be non-equity based (for example subcontracting, licensing, franchising, or outsourcing). Sometimes linkages are 'backward' to suppliers and subcontractors ('upstream'), sometimes they are 'forward' to distributors, agents or franchise holders ('downstream'). To these two forms can be added 'horizontal' linkages between firms operating within similar activities - for example strategic alliances between competitors and/or technology partners (see Table I.2).

Table 1.2 A typology of interfirm transactions

\begin{tabular}{|c|c|c|c|}
\hline & Backward & Forward & Horizontal \\
\hline $\begin{array}{l}\text { Pure market } \\
\text { transaction }\end{array}$ & $\begin{array}{l}\text { Off-the-shelf purchase } \\
\text { Spot market transaction }\end{array}$ & Off-the-shelf sales & $\begin{array}{l}\text { Technology and } \\
\text { management service } \\
\text { sale on market } \\
\text { conditions }\end{array}$ \\
\hline $\begin{array}{l}\text { Short-term } \\
\text { linkage }\end{array}$ & $\begin{array}{l}\text { Once-and-for-all or } \\
\text { intermittent purchase on } \\
\text { contract }\end{array}$ & $\begin{array}{l}\text { Once-and-for-all or } \\
\text { intermittent sale on } \\
\text { contract }\end{array}$ & $\begin{array}{l}\text { Technology and } \\
\text { management service } \\
\text { sale as part of strategic } \\
\text { alliance }\end{array}$ \\
\hline $\begin{array}{l}\text { Long-term } \\
\text { linkage without } \\
\text { equity }\end{array}$ & $\begin{array}{l}\text { Contractual } \\
\text { arrangements for } \\
\text { procurement of inputs } \\
\text { Subcontracting of final or } \\
\text { intermediate products }\end{array}$ & $\begin{array}{l}\text { Contractual } \\
\text { relationship with } \\
\text { distributor or customer }\end{array}$ & $\begin{array}{l}\text { Joint projects with } \\
\text { competing firms, for } \\
\text { example R\&D alliances } \\
\text { or joint marketing and } \\
\text { distribution } \\
\text { Licensing and } \\
\text { franchising agreements }\end{array}$ \\
\hline $\begin{array}{l}\text { Long-term } \\
\text { linkages with } \\
\text { equity }\end{array}$ & $\begin{array}{l}\text { Joint venture with } \\
\text { supplier } \\
\text { Establishment of supplier } \\
\text { affiliate }\end{array}$ & $\begin{array}{l}\text { Joint venture with } \\
\text { distributor or customer } \\
\text { Establishment of } \\
\text { distributor affiliate }\end{array}$ & $\begin{array}{l}\text { Joint venture aimed at } \\
\text { market entry }\end{array}$ \\
\hline
\end{tabular}

Source: based on UNCTAD, 2001

The nature of the linkage between a foreign investor and a local firm obviously has implications for the scope and content of spillover effects on host country firms. ${ }^{2}$ One may easily accept that a short-term contractual agreement on a specific task may create less opportunities for learning and upgrading for the local firm than a long-term subcontracting collaboration involving a large resource exchange between the MNC and the local firm. It has been argued that with economic development, linkages between MNCs and local firms become deeper and more reciprocal because the absorptive capacity and skills of the local industrial base increases (Scott-Kennel and Enderwick, 2005). The literature also argues that it makes a difference where in the value chain the linkage partners are placed. Especially backward linkages to suppliers and subcontractors are considered to 
have large spillover potential whereas horizontal linkages are believed to produce less spillover on local firms (UNCTAD, 200I; Nunnenkamp, 2004). The spillover potential of forward linkages to agents, distributors and franchise holders is less researched, but it is argued that also forward linkages may have profound spillover potential (Hansen et al., 2006).

\section{I.4 The theory of multinational corporation-local firm relations}

The theory on MNC-local firm relations is mainly informed by three economic traditions, namely trade economics, industrial organization and international business:

\subsubsection{Trade economics}

In the original trade theory based on comparative advantages, production factors were assumed to be immobile while goods could move freely. Trade Economics later included capital movements in the equation by allowing for capital flows between capital-rich and capital-poor countries. A partial equilibrium comparativestatic approach was developed, aiming to evaluate the distribution of the gain for a capital-scarce country of additional investments coming from a capital-abundant country (MacDougall, 1960). Aliber (197I), in a similar way, argued that FDI was a consequence of a kind of arbitrage between countries with strong and weak currencies. From a welfare perspective, it was implied that the additional foreign capital could enhance welfare by increasing production and improving the allocation of scarce resources. The main disadvantage of these early models was that they viewed the multinationals as part of the theory of portfolio capital flows and considered the effects of FDI as being equal to those of other forms of capital.

Relaxing the assumptions of the original neoclassical trade economic framework, New Trade Economics allowed for the possibility of economies-of-scale and product differentiation (Helpman, 1984; Helpman and Krugman, 1985; Markusen, 1984), paving the way for an understanding of MNCs in equilibrium models. The New Trade Economic theory materialized into two main frameworks, the verticalmultinational and the horizontal-multinational framework. ${ }^{3}$ The vertical multinational separates the stages of production geographically and localizes labor-intensive activities in developing countries to take advantage of relatively abundant unskilled labor, whereas the horizontal multinationals duplicate the same product or service in different locations (Markusen, 1984). In terms of MNC effects, New Trade Economics predicted that MNCs produce both crowding-in effects and crowding-out effects (Markusen and Venables, 1999). As MNCs possess some 
special advantages over the indigenous host-country rivals, such as superior technology or lower costs due to economies of scale, they may initially produce crowding-out of local investment. On the other hand, they may in the longer run 'crowd in' due to high transportation costs that force the MNCs to source locally, thereby creating a catalyst impact on local firms in the intermediate goods industry. The catalyst effect results from MNCs' demand for a larger variety of intermediate goods and a rise in the quantities supplied which stimulates economies-of-scale. The equilibrium that will emerge depends on the impact of both opposed effects.

While New Trade Economic models abandoned the strict assumptions of the original neoclassical theory thus empirically producing more robust predictions, they still belong to the neoclassical body, which may be effective in tackling problems of resource allocation and equilibrium thanks to prize- and/or quantitybased adjustment mechanisms, but is inadequate in conceptualizing the variations and complexity in MNC strategy and effects.

\subsubsection{Industrial organization}

By the late I950s and early I960s, the Trade Economic partial equilibrium models were fundamentally challenged from an Industrial Organization perspective. The Industrial Organization literature on MNCs aimed to study the consequences of 'the entry into a national industry of a firm established in a foreign market' (Caves, 197I, p. I). Markets are full of imperfections of the structural type - proprietary technology, privileged access to inputs, economies of scale, control of distribution systems and product differentiation (Bain, 1956) - that can be used by firms to increase their monopoly power and to internationalize. The main idea of this school of thought is that the characteristics of the industry fundamentally affect the strategy and performance of firms, and indeed, the effects that MNCs may have on host countries. Thus, industry characteristics may impact whether or not MNCs crowd in or crowd out local firms; whether they transfer technology and knowledge from parents to affiliates; whether they foster linkages to local firms; and whether they suppress or foster competition in the host country (Nunnenkamp and Spatz, 2002).

\subsubsection{International business}

From the mid-I970s, microeconomic literature on MNCs emerged, literature that later would provide one of the main pillars of International Business. Inspired by Stephen Hymer's seminal PhD thesis in 1960, early International Business literature, in line with the Industrial Organization 'Structure-Conduct-Performance paradigm', argued that multinationals possess special assets in comparison to local firms that allow them to overcome the disadvantage of foreigness (Hymer, 
1960). The firm-specific know-how, its knowledge-capital and its technology assets appear to be key ownership advantages. Internationalization per se reinforces the multinational's advantages by providing opportunities to divide marketing risks, by slicing up the value chain on the base of the territories' comparative advantages, and by providing access to new resources and assets. The multinationals' ownership advantage is often reinforced by the ability they have to access finance, internationally and in the host economy, compared to local firms which are most of the time financially constrained.

Later, the International Business theory of MNCs directed more attention to advantages related to the ability to organize cross-border transactions in the face of market imperfections (Buckley and Casson, 1976), the ability to leverage resources across borders (Peteraf, 1993) or the advantages related to coordinating knowledge diffusion and development across borders (Kogut and Zander, 1993). Dunning (1988; 200I) sought to integrate many of these understandings of MNCs in his 'eclectic' OLI framework, which has become a dominant framework for understanding MNCs within the International Business literature.

International Business is essentially about understanding the existence, conduct and performance of firms involved in cross-border business transactions and therefore the efficiency or welfare effects of these transactions received little attention. Basically, welfare issues remained the domain of trade economists and industrial economists and to some extent political scientists analyzing the role played by MNCs in policy formulation at the national and international level (see for example Spar and Yoffie, 1999; Moran, 2002). Insofar as International Business analyzed spillovers, it was mainly in the context of finding effectively controlled strategies avoiding spillovers; indeed, to many International Business theorists, the very purpose of the MNC was to avoid knowledge and technology being spilled over to other firms. ${ }^{4}$

Nevertheless, as argued by Forsgren (2002), the received International Business theory embodies some fairly straightforward assumptions and predictions regarding MNC effects on host countries. The early market power current within International Business argued that MNCs were essentially extensions of market power in foreign locations (Hymer, 1960). As such, MNCs would by implication tend to crowd out local investment and reduce consumer welfare by suppressing competition. Moreover, host countries would have great problems matching the bargaining power of MNCs and would tend to strike unfavorable deals with the MNCs. By the mid-I97os, this critical view was challenged by a number of scholars who argued that MNCs existed mainly to bridge market imperfections in cross-border markets for intermediary goods, for example transaction costs. As such, MNCs were expressions of efficiency and therefore welfare enhancing (Rugman, 198I). Similarly, more recent resource-based perspectives (Peter- 
af, 1993) and knowledge-based perspectives (Kogut and Zander, 1993) look at MNCs as superior vehicles for cross-border knowledge and resource transfer and thereby as potentially benefiting host countries. International Business theory says little about the extent to which MNCs produce spillovers on local firms. But it can be inferred from the market-power view that if MNCs are about extending market power to foreign locations, local firms may be harmed. And if MNCs are about the effective transfer of superior knowledge and technology to subsidiaries, they may have a high potential for producing demonstration and competition effects. Moreover, as recognized by modern International Business theory, as MNC boundaries are becoming increasingly fuzzy (Cantwell and Narula, 20or) and as MNCs are increasingly locating the development and exploitation of their ownership-specific advantages in business networks and strategic alliances (Ghoshal and Bartlett, 1990), new opportunities for acquiring technology, knowledge and market access for local firms in emerging economies are provided.

\section{I.5 Research on multinational corporation-local firm relations}

A great deal of empirical literature on linkages and spillovers has evolved in recent years. This literature is theoretically informed by the above-mentioned Trade Economic, Industrial Organization and International Business literature. The empirical literature essentially studies the multinational-local firm nexus through three main methods: formal modeling (see for example Rodriguez-Clare, 1996; Markusen and Venable, 1999), statistical analysis (for overviews, see for example Caves, 1996; Blomström and Kokko, 1997; Nunnenkamp, 2004; Görg and Greenaway, 2004; Merlevede and Schoors, 2005), and case studies (Altenburg, 2000; Hansen and Schaumburg-Müller, 2006; Giroud, 2007). The three methods are based on different kinds of reasoning regarding fundamental issues such as case selection, operationalization of variables and the use of inductive and deductive logic. Each method has comparative strengths and limits.

Thematically, the empirical literature focuses on different aspects of the MNClocal firm nexus. One group of studies treats MNCs as more or less homogenous actors producing similar effects on host countries, and little differentiation between industries, MNC strategies and countries are made. Another group of studies takes its point of departure in the heterogeneity of MNCs and countries and differentiates MNC effects based on factors such as industry characteristics, MNC strategy, and host country characteristics. Finally, a group of studies looks at the effects of MNCs on local firms according to the specificities of the transaction relationship - the linkage - between the MNC and the local firm. The three groups of studies and their interrelationship are depicted in Figure I.I. 
Figure 1.1 An overview of research on spillover effects

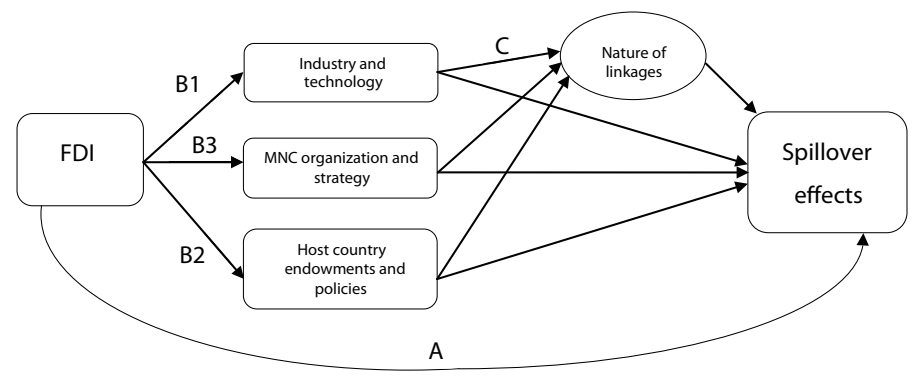

In the following section, we will organize our review of the literature according to this figure.

\subsubsection{General effects of foreign direct investment $(A)$}

The question of the magnitude of the MNC spillovers on a host-developing country has been tackled by several generations of economists since the seminal work of Caves in 1974. In general, these produce mixed results in regard to the overall state of spillover effects in developing countries and transition economies. Some find that MNCs have positive spillover effects on local firms in developing countries and transition economies in terms of productivity (Blomström and Pearson, 1983; Dobson and Chia, 1997), technology transfer to local industry (Rhee and Belot, I990; JBIC Institute, 2002), wages (Lipsey and Sjöholm, 2004) or integration by imitation of international trade (Aitken et al., 1997). As stated by Dunning (1992, p. 456 (quoted in Altenburg, 2000)), the findings of a large number of studies over the past 30 years are virtually unanimous that the presence of foreign owned firms has helped raise the standards and productivity of many domestic suppliers and that this has often had beneficial spillover effects on the rest of their operation.' Others find that these generalized interpretations of FDI spillovers rest on shaky empirical foundations. Rodrik (I999, p. 39) argues that 'todays policy literature is filled with extravagant claims about positive spillovers from FDI... [yet]... the hard evidence is sobering.' Thus, it is questioned whether FDI produce statistically significant effects on economic growth (Caves, 1996; Nunnenkamp, 2004), total factor-productivity growth (Haddad and Harisson, 1993; Kokko, 2002; Lispey and Sjöholm, 2005; Ayyagari and Kosova, 2006), wages (Lipsey and Sjöholm, 2004), competition (Kugler, 2000; Blalock and Gertler, 2007), or export (Kokko et al., 200I). Indeed, some studies find negative impacts of FDI on local firms in developing countries (Aitken and Harisson, 1999) and in transition economies (Djankov and Hoekman, 2000; Konings, 2000). 
Thus, the extensive empirical literature analyzing the multinational-local firms nexus neither provides conclusive results on the general impact - positive or negative - of multinationals on the productivity of the local firms, nor on the magnitude of impact. The lack of firm conclusions in regard to spillovers is of course related to the fact that MNCs may produce different amounts of spillovers under different conditions. Thus it has emphatically been argued that the spillover literature needs to discriminate better between different factors shaping spillovers (Nunnenkamp, 2004; Görg and Greenaway, 2004). In the following section, we will review the research on spillovers that qualifies under which conditions MNC spillovers may take place and when not.

\subsubsection{Industry factors $\left(B_{1}\right)$}

It is commonly argued that much of the variation in the interpretation of MNC spillovers depends on whether we are talking about vertical or horizontal spillovers (also called inter-industry and intra-industry spillovers). In his seminal study of spillovers, Caves (1974) used cross-sectoral data on the correlation between FDI and local industry productivity. Here significant positive productivity effects of FDI were detected. However, one main problem of Caves' approach was that MNCs may be entering high productivity sectors rather than being the cause of high productivity. Indeed, later results produced by panel data analysis were somewhat more ambiguous with regard to intra-industry spillover effects (Görg and Strobl, 200I); some studies showed direct negative effects of FDI (Aitken and Harrison, 1999), while others detected no effects (Haddad and Harrison, 1993; Kugler, 2000). Meyer (2004) concludes that 'overall evidence does not support the proposition of positive intra-industry productivity spillovers, with the possible exception of special circumstances such as the transition from central planning to a market economy'

In contrast, studies of vertical spillovers produce more robust results. Several studies find evidence of productivity spillovers on related industries in Lithuania (Javorcik, 2004), Indonesia (Blalock and Gertler, 2007), Columbia (Kugler, 2000), Hungary (Schoors and van der Tool, 2002; Halpern and Muraközy, 2005) and the Czech Republic, Poland and Slovenia (Damijan et al,, 2003). Most of these studies focus on effects upstream in the value chain, but there are also studies that find positive downstream effects, for example franchise holders (Altenburg, 2000) or distributors and agents (Hansen et al., 2006). The reason why we tend to find more evidence of vertical spillovers than horizontal spillovers is obviously that MNCs are less concerned with sharing technology and know-how with firms in other industries as these are less likely to become competitors. 
Much of the spillover literature focuses on the effects of manufacturing MNCs. However, as pointed out by UNCTAD (2004), services are increasingly being internationalized, both service industries proper and service-value-chain activities within manufacturing firms. The internationalization of information technology (IT) and other business services offers new opportunities for the integration of firms in emerging economies into the global economy as evidenced by the successful growth of Indian IT and business process outsourcing (BPO) firms. The empirical material focusing on spillovers in services is still very poor and inconclusive. Alfaro (2003) for example, finds that FDI has exerted an ambiguous effect on economic growth in the service sector of a sample of 47 countries (including developed and developing countries) over the 1985-1999 period. So too does the academic research differentiating the FDI impact on the basis of technology intensity of the foreign investor. Bosco (200I) for example, suggests that the Hungarian firms did not benefit from the presence of foreign firms in high-technology industries. On the one hand, foreign high-technology industries have a higher spillover potential than low-technology companies, but on the other hand, they particularly want to prevent their technology from leaking over to local firms (especially in countries with weak intellectual property rights), and local firms in less developed countries might fail to absorb advanced technologies and information.

\subsubsection{Country factors $\left(B_{2}\right)$}

It is increasingly acknowledged that many of the detected FDI spillover effects depend on the characteristics of the host economy (Nunnenkamp and Spatz, 2003). Some countries have a higher capacity to absorb effects of MNC activity than others. Thus, a recurring theme in the literature on spillovers is that the direction and magnitude of the impact are conditioned by a certain threshold of development. In particular, it appears that spillovers depend on GDP per capita so that the higher the GDP per capita, the larger the spillovers (Blomström et al., 1994).

The underlying dynamic here is, of course, that the sophistication of the local business environment influences spillovers to a large extent. In particular, the technology gap between local firms and MNCs has been seen as an important determinant of spillovers. While some have argued that a high-technology gap produces more spillovers (Kojima, I973), most observers argue that a low-technology gap is conducive of spillovers (De Mello, 1999) as is a high skills level in the local labor force (Borensztein et al., 1998). Görg and Greenaway (2004) conclude that economic backwardness functions as an impediment to spillovers and Nunnenkamp (2004) suggests that spillovers are higher when the technology gap 
between the foreign investor and the local economy is small. Spillovers depend on the extent to which local firms have invested in developing learning and innovation capabilities and Kokko et al. (1996) argue that when the difference of efficiency between multinationals and local firms is too large, local firms may be unable to absorb new technology and know-how, and multinationals may be dissuaded from interacting with local firms. Thus, we have a dilemma with regard to spillovers: spillovers increase in significance and importance when the differences in technology levels are high (Gerschenkron, 1962); however, the ability to absorb falls when the technology gap is wide.

The ability of local industry to absorb spillovers has been intensely explored in the growing research on absorptive capacity (see for example Cohen and Levinthal, 1990; Zahra and George, 2002; Narula and Lall, 2004), where absorptive capacity refers to the ability of local firms to identify, integrate and exploit knowledge from MNCs. In countries with low levels of industrial development, typically the least developed countries, there will be no or few firms that can absorb the knowledge and technology of MNCs and thereby few spillovers will occur. As an infant local industry emerges, we will see growing arms-length spillovers in the form of competition and demonstration effects. As local industry becomes more advanced - partly as a consequence of arms-length spillovers from MNCs - we will see the evolution of deeper and more reciprocal linkages between MNCs and local firms with higher spillover potential (Scott-Kennel and Enderwick, 2004).

\section{THE ROLE OF GOVERNMENTS}

It is broadly acknowledged that government policy plays a pivotal role in producing spillovers, although government intervention does not always produce the spillover effects intended. A general observation is that open trade regimes tend to produce types of spillovers different from those produced by restrictive, inward-oriented policies (Balasubramanyam et al., I996; UNCTAD, 1998; Altenburg, 2000; Nunnenkamp, 2004). Open trade regimes may on the one hand reduce spillover as they allow for the import of intermediate products and resources as an alternative to local sourcing. On the other hand, open trade regimes may encourage MNCs to transfer more advanced types of production to host countries and use them as export platforms thus increasing the likelihood of knowledge and technology spillovers. Likewise, intellectual property rights policies may make a huge difference; if there is lax intellectual property rights protection, MNCs may be reluctant to share any knowledge or technology with local firms, for example in licensing agreements.

Where host governments, a few decades ago, used highly crude discriminatory measures to tame and domesticate FDI (for example local ownership requirements 
or local content requirements), the investment measures in the post-Washington consensus era tended to opt for across the board FDI attraction. Today, a broad variety of measures are adopted which are constantly assessed against the constraint provided by international trade rules of non-discrimination. Thus, governments actively seek to promote spillovers directly through local content regulations, tariffs or subsidies, indirectly through infrastructure programs and education policies (Altenburg, 2000; Spar, 2008). Many emerging economies are further promoting FDI spillovers by developing the capabilities of local supply industries to link up to MNCs and thereby potentially absorb the technology and knowledge. A particular issue concerns subsidies and other incentives which are widely used to promote spillover generating FDI. The literature intensely debates whether such measures are effective in achieving spillovers on local industry (Blomström and Kokko, 2003; Tavares and Young, 2005). Finally, some countries promote the development of clusters as a way to enhance spillovers. The idea is that a cluster of related and supporting industries may enhance the likelihood of MNC location and increase the chances of local firms benefiting from the MNC presence due to industrial specialization, higher concentration of specialized labor skills and geographical proximity (Thompson, 2002; De Propis and Driffield, 2005).

\subsubsection{The strategies of multinationals $\left(B_{3}\right)$}

Spillovers will also depend on the strategies of MNCs, a fact that is often ignored by the more macro-oriented spillover literature. Thus, most spillover research employs relatively aggregated FDI data, typically at country or industry level and little distinction of spillover impacts based on the specificities of MNC strategies are made (Nunnenkamp, 2004). However, literature increasingly emphasizes the heterogeneity of MNCs when determining spillover effects, arguing that spillovers depend on MNC specific factors such as ownership configuration (Javorcik and Spatareanu, 2008), export orientation of the subsidiary (Sgard, 200I), subsidiary mandate (Tavares and Young, 2005) or corporate governance (Meyer, 2004). The investment motive of the MNC appears to be a particularly crucial determinant of spillovers (Reuber et al., 1973; Pearce and Papanastassiou, 1999; Altenburg, 2000; UNCTAD, 2000; Belderbos et al., 200I; Dicken, 2003). Generally, it is argued that efficiency-seeking investors foster deeper but less extensive spillovers on local firms than market-seeking investors (Nunnenkamp, 2004; Hansen et al., 2009). The organization of the MNC also appears to have implications for the amount and quality of spillover; for instance, Forsgren (2002) has argued that MNCs that are organized as network or matrix organizations have higher knowledge spillover potential than MNCs organized as multidomestic or global companies. 


\subsubsection{The nature of linkages (C)}

In recent years, emerging literature has directed attention toward the organizational modalities through which spillovers occur, that is, linkages. This literature is relatively novel; as argued by Meyer (2004) in his review of the spillover literature, 'future research ought to prioritize the study of vertical relationships by analyzing how spillovers arise in individual interactions of a multinational firm and a local agent or firm. What characteristics of relationships facilitate spillovers?'

The linkage literature essentially treats linkages as an intermediary variable, moderating and shaping FDI-spillover effects. So, with one-sided and hierarchical relations between foreign and local firms, we may get dependent linkages with few catalytic effects on the local business environment, with collaborative and interactive relations, we may get developmental linkages with huge catalytic effects in terms of technology and skills upgrading (Dicken, 2003; Scott-Kennel and Enderwick, 2005). The early linkage literature (see for example Singer, 1950) argued that MNCs often fail to integrate in local industries and sectors, providing little impetus for development. Thus, the presence of a multinational or several multinationals could take the form of 'enclaves' which do not communicate with the rest of the economy. Linkages were mostly found to be missing in sectors in which multinationals are internalizing their activity and/or importing the bulk of the needed intermediates (UNCTAD, 200I) for example in agriculture and in mining activities (Larsen et al,, 2009). On the other hand, multinationals in other industries appeared to foster broad linkages in the host economy by creating industries that supply the MNC and by inducing forward industries to use the multinational's output as inputs, the so-called crowding-in effect of FDI (Wilkins, 1998). It has even been argued that some MNCs may be 'developmental' in the sense that they have the creation of linkages as a key component in their strategy (Altenburg, 2000). Rodriguez-Clare (1996) argued that linkages will become more intense, the more complex the good produced by the multinationals, the higher the transport costs, and the more similar the intermediate products produced in the host and home country. Enclave behavior results from low communication costs and from the production of different varieties of intermediate products in the home and host countries of the multinationals. Lin and Saggi (2007) found that MNCs either choose an anonymous short-term market interaction with suppliers or prefer a long-term contractual relationship and engage in technology transfer to suppliers who in turn accept to serve the multinational exclusively. The multinational's entry under the exclusivity clause has a de-linking effect by which the multinational displaces pre-existing linkages between local firms and their suppliers. The exclusivity clause reduces the rivalry among local suppliers which tends to reduce the aggregate output level of the intermediate 
goods industry but increases the technology transferred to local suppliers. The net effect can either be positive or negative. When the multinational chooses an anonymous market interaction, the number of competing suppliers that serve the multinational is large, but the technology transferred is poor.

Giroud and Scott-Kennel (2009) consider that three key attributes determine the spillover impact of linkages: quality, quantity and scope. Quality is linked to the magnitude of transfer of resources, which occurs between subsidiaries of MNCs and local firms. Duration of the relation is central because the development of trust between firms positively influences interfirm exchange and learning. Quantity refers to the number of interfirm relationships formed in the host country, as well as the value added by local firms in value chains managed by MNCs. Scope refers to types of linkages: they may concern other firms in the value chain or take the form of collaboration with competitors or firms in other industries and collaboration with local institutions. The larger the types of linkages formed (supply-chain, collaborative) and the industries/institutions concerned the greater developmental impact is expected.

The nature of integration between MNCs and local firms in global value chains may also be of importance for spillovers. Thus, the global value-chain literature (see for example Gereffi, Sturgeon and Humphrey, 2005; Sturgeon, 2008, for overviews) examines how global value chains configure production patterns globally. Large dominant lead firms in the North organize these value chains, with developing country firms being integrated in more or less dependent positions. The literature essentially identifies five different linkage structures between MNCs and local firms: integrated, captive, modular, relational and market. These linkage structures provide different spillover opportunities for emerging economy firms in terms of upgrading and learning. A distinction between four types of upgrading spillovers is made; process upgrading, product upgrading, functional upgrading and value-chain upgrading. Whereas there may be opportunities for process upgrading and even product upgrading for developing country firms in linkage collaborations within global value chains, MNCs will rarely be willing to assist local firms in moving into higher value adding activities such as R\&D or marketing and sales. Thus, due to the linkage structure inherent in global value chains, the spillover potential on firms in emerging economies appears to be limited.

\section{I.6 Contributions to the book}

We have now provided an overview of the extant literature on spillovers in terms of theoretical orientation as well as the main issues debated. In the following section we will present the main findings of the spillover studies presented in this 
book and discuss how the studies are all contributing to our understanding of MNC-local firm interaction.

Part II of the book provides four spillovers case studies:

During the last twenty years, Hungary has attracted significant FDI in the manufacturing industry and especially in the automotive and electronics sectors. Empirical literature assessing the impacts of FDI in these industries is relatively abundant. On the other hand, the FDI phenomenon in business services - which is relatively new in economies in transition - has hardly been studied at all. The extant literature, with the notable exception of Alfaro's study (2003), is short of studies of spillovers of MNCs in the services sector. The chapter The impact of foreign direct investment in business services on the local economy: The case of Hungary written by Magdolna Sass aims precisely at filling this gap by assessing the impact on the local economy of offshore outsourcing and offshoring of services by MNCs. Hungary has become one of the leading locations in attracting FDI in business-services projects in the East-Central European area. Thanks to interviews taken from eight large companies which created approximately 5,500 jobs (out of roughly 20,000 jobs in the business service activity), Magdolna Sass suggests that spillovers are scarce because backward linkages, but also forward linkages, with indigenous firms remain limited. This can be explained by at least three main factors: I) FDI is recent in the business services and linkages only develop progressively with the growing embeddedness of MNCs in their new host environment. 2) Since almost the totality of the services are 'exported', forward spillovers are absent. Finally, 3) Magdolna Sass detects 'endogamy' behavior, that is, cooperative relationships between the foreign-owned firms while sourcing from local firms is confined to buying various 'basic' services, such as cleaning, security services, catering, and certain training services, and to the use of local infrastructures (telecommunications, electricity, financial services, other infrastructures). In the near future, potential spillovers may transit through the mobility of workers. Indeed, most of the jobs in the MNCs providing business services belong to the medium- and medium-high skilled categories, and some young trained employees (who represent the bulk of the workforce in the MNCs) may create their own company or go to locally-owned companies, although, currently, employees move more between foreign-owned companies than from MNCs to local firms.

The chapter Do Multinational companies transfer technology to local small and medium-sized enterprises? The case of the Tegal metalworking industry cluster in Indonesia by Tulus Tambunan consists of a case study of clustered metal workshops in the automotive and shipbuilding subsectors in the district of Tegal in Indonesia. Based on a sample consisting of 34 respondents including owners of inti (first tier supplier) and plasma (second tier supplier) who have subcontract- 
ing businesses, local workshop owners who supply only to retail markets, local government officials, and non-government organizations, the author assesses the MNCs' role in technology transfer to SMEs in Indonesia. Our review of the literature in Part I has demonstrated that the technological capacity of local firms is a decisive determinant of spillovers. Tulus Tambunan's case study confirms this relation. The author suggests that among the different channels through which technology is transferred internationally, subcontracting arrangements managed by MNCs is probably the most promising channel for the metal industry in Indonesia. The author highlights the prominent role played by the Japanese company Komatsu which has actively developed subcontracting production linkages with Tegal metal workshops and contributed to the development of the Tegal metalworking industry cluster. Yet Tulus Tambunan suggests that technology transfer concerns a limited number of local firms: only firms which have already succeeded in mastering a certain level of technology capability become long-term partners of MNCs. The Tegal case study also demonstrates that small enterprises lack the technological, financial and management capabilities required to gain benefit from the presence of MNCs. In order to avoid a dualistic development of the Tegal metalworking industry the government should focus on the capacity building of the less advanced SMEs and especially of the smallest firms.

In the chapter African small and medium enterprises and the challenges in global value chains: The case of Nigerian garment enterprises Osmund Osinachi Uzor adopts an International Business perspective and focuses on the nature of linkages linking multinationals to local enterprises. He argues that it has become of central importance for African garment producers to integrate the Global Value Chains (GVCs) driven by MNCs. Yet with the exemption of South Africa, SMEs in sub-Saharan Africa are marginalized in GVCs. This is also the case for the garment producers in Nigeria. To highlight the challenges small and medium Nigerian garment producers face in order to participate in the GVCs' activities, Osmund O. Uzor interviewed 60 entrepreneurs and their workers in $\mathrm{Aba}$ in the state of Abia in Nigeria, between 2003 and 2008. The empirical study suggests that the poor integration in GVCs results from insufficient production upgrading. Most of the firms in Aba are small firms which face a double constraint: a financial constraint preventing them from acquiring more modern equipment and a human resource constraint due to the low level of skilled workforce. This empirical work demonstrates that even in low-technology industries such as the garment industry, with the globalization of value chains, countries with insufficient capabilities fail to integrate the buyers' world networks and consequently do not have access to the information concerning the consumer tastes, market niches and so on, that would allow them to advance their production to world standards. Policies should focus de facto on how the capability gap in micro and 
small enterprises could be reduced so that linkages with large firms and global buyers might be developed.

In the chapter Mutual productivity spillovers and regional clusters in Eastern Europe: Some empirical evidence Chiara Franco and Kornelia Kozovska question whether spillovers between MNCs and local firms are more present in clusters than outside. Our theoretical framework (Part I) has suggested that industry factors matter and some empirical research has tended to demonstrate that clusters facilitate linkages and spillovers. Hence, one may expect spillovers - that is 'direct' spillovers from MNCs to local firms but also 'reverse' spillovers from local firms to MNCs - to be larger in clusters than outside since industrial specialization, higher concentration of specialized labor skills and geographical proximity should foster linkages between the two kinds of firms. In order to assess the presence of a positive 'cluster effect' the two authors use a econometric model in which they process firm-level data of 4,III firms from Poland and I,547 from Romania over the 2000-2006 period. Contrary to expectations, the two authors fail to find direct spillovers in clusters in Poland and Romania. Although some local firms are part of regional clusters, they are still not able to effectively create linkages and benefit from the various externalities which are present in clusters. 'Direct' spillovers are neither detected in low-technology sectors nor in high-technology sectors. Looking into the reverse effect, even though not statistically significant in many cases, the results suggest that foreign firms benefit from being located within clusters. These results question policies of many developing countries and transition economies, and especially the Central European countries, which have put the creation of clusters at a high position in their economic agenda as a catalyst for the upgrading of local firms. The presence of local firms in clusters may facilitate the creation of linkages, yet it does not guarantee that they will benefit from positive externalities resulting from the activity of MNCs.

Part III of the book moves into discussions of policies and programs to promote linkages and spillovers from FDI:

In Part I we have suggested that the literature intensely debates whether incentives policies are effective in achieving spillovers on local industry. In the chapter Scope and effectiveness of foreign direct investment policies in transition economies, Črt Kostevc, Tjaša Redek and Matija Rojec analyze the investment incentives policies of transition economies from the point of view of their effectiveness in attracting more and better FDI, and contribute de facto to adding new material to the incentives policy issue. Although investment incentives are a secondary determinant of FDI they are increasingly expected by foreign investors when looking for an investment location. The chapter provides an overview of measures adopted in various transition economies. Transition economies' investment incentives are predominantly of the behavioral type, targeted towards high-tech 
sectors, transfer of technology, $\mathrm{R} \& \mathrm{D}$ and training. In principle, incentives are equally available for foreign and domestic firms, but implicitly most of them seem to target foreign investors. Increasing attention is also paid to the delivery of incentives, namely to the assurance that the incentives granted will really bring the expected payoffs. The overview of the incentives schemes of selected transition economies broadly suggests that such incentives have limited effectiveness. The main message for FDI policies of transition economies may be that, conceptually, FDI-related policies should primarily be regarded in terms of potential spillover effects, meaning that an increase of local firms' absorption capacity is of paramount importance if FDI is really to be an agent of development.

In the chapter Policies for attracting foreign direct investment and enbancing its spillovers to indigenous firms: The case of Hungary, Katalin Antalóczy, Magdolna Sass, and Miklós Szanyi also evaluate the measures adopted by Hungary to attract FDI and focus on the measures aiming at enhancing backward linkages. Three phases of Hungarian FDI policy are identified: An early phase starting already before 1989 when Hungary as one of the first Central and Eastern European (CEE) countries opened up for FDI and continuing to around 1996. In this phase, FDI was aggressively promoted and FDI attraction became closely tied to privatization programs. A second phase (1996-2003) was a normalization phase, where FDI policy became more selective. Hungary offered extensive incentives to foreign investors, but was increasingly challenged by other CEE countries offering even more generous incentives, leading to an incentive escalation. The third phase is closely connected to EU enlargement where competition concerns moved to the forefront at the expense of selective incentive schemes. In this phase, Hungary had to move towards non-discriminatory measures to attract FDI, for example tax reductions, infrastructure developments or the establishment of industrial parks. One of the key points of the chapter is that Hungary realized at an early stage that simply attracting FDI was not enough to benefit from FDI. Thus, the country, as one of the first CEE countries, adopted accompanying supplier development programs. The chapter provides a detailed account of the evolution of these programs and raises the question of whether they have been effective. As there is little empirical research on the effectiveness of Hungarian linkage promotion policies, the chapter offers two short company case studies of large MNCs' investments receiving substantial support from the Hungarian government. One of the companies, Electrolux, facilitated the formation of many local linkages but of low technical sophistication, while the other company, Nokia, created few linkages as the production was technically advanced. The two cases offer a paradox for FDI policy, as from a development perspective highly desirable advanced technologies are often associated with MNCs that have closely integrated global value chains and therefore result in relatively few local linkages, whereas less ad- 
vanced technologies will be associated with MNCs that create larger linkages to the local economy.

In the chapter Policies and institutions on multinational corporation-small and medium enterprise linkages: The Brazilian case, Delane Botelho and Mike Pfister observe that Business Linkages (BL) between MNCs and local suppliers can create significant spillovers on local SMEs in the form of information and technical knowledge exchange, production efficiency, productivity growth, and market diversification. Investment Promotion Agencies (IPAs) can play a crucial role in promoting such linkages. The chapter evaluates current BL policies and programs in Brazil, the largest FDI recipient in Latin America. The chapter starts out by describing the complex FDI promotion architecture which exists in Brazil at the federal and regional level and which dates back to the late I980s, emphasizing programs that seek to promote BL between MNCs and SMEs. The chapter moves on to present the results of an empirical study of BL in Brazil, how they are structured, where they are leading to the development of local firms, and what role BL programs have played in promoting these BLs. One of the conclusions is that while Brazil has many policies promoting SMEs, it still lacks effective BL promotion policies and BLs are mainly driven by the business sector rather than the government. The chapter ends with a number of tangible policy recommendations, for example that BL programs should be further developed, that education and capacity-building activities should be intensified vis-à-vis SMEs, and that BL programs should be anchored outside governments (for example in business service providers). Overall, the chapter warns that linkage dynamics are highly context-dependent and that it is therefore essential for BL programs to be flexible and anchored at the local/regional rather than the federal level.

In the chapter Is attracting foreign firect investment the only route to industrial development in an era of globalization? The case of the clothing and textiles sector in South Africa Søren Jeppesen and Justin Barnes analyze the industrial development strategy adopted by South Africa for its textile industry and the role played by FDI in this strategy. In recent years this industry has seen a profound decline in terms of the employment generation, the contribution to GDP, turnover and performance. Simultaneously, foreign producers have thrived and imports especially from China have increased enormously. The chapter essentially examines whether the demise of the South African textile industry can be attributed to a failed industrialization strategy. Theoretically, four generic industrialization strategies can be envisioned: FDI attraction; integration into Global Value Chains; licensing and joint venture agreements; and the export of own-designed products. The South African government has clearly chosen to follow the latter strategy of export orientation without relying directly or indirectly on FDI. This in contrast to other African countries, such as Lesotho, Mauritius and Ken- 
ya, which all rely extensively on FDI. Thus, the chapter traces the failure of the South African strategy to its inability to use FDI to access technology, designs, and markets through licensing, subcontracting and joint ventures with MNCs. Only through closer linkages between foreign firms and local producers would South African producers have been able to close the 'gap' related to technology or marketing; indeed, the chosen export-oriented strategy with no FDI linkages is the only option South Africa should not have opted for.

\section{I.7 Conclusion}

Taken together, we believe that the chapters of this volume contribute to the received literature on MNC-local firm interaction in emerging economies in a number of ways. First, the studies provide new insights into spillover dynamics in the hitherto little analyzed empirical contexts of emerging economies of Eastern Europe, Asia, Africa and Latin America. We obtain some interesting glimpses of spillover dynamics in different regions of the world. The book sheds additional light on the spillover literature of economies in transition in a comparative perspective to developing countries. Spillovers and consequently the upgrading of indigenous firms in transition economies have been less present than was initially expected in the economics of transition literature. Despite the pre-existence of an industrial tradition and a relatively high level of human capital, but also active FDI policies, spillovers from MNCs onto local firms have been rather disappointing. Although transition economies differ from developing countries regarding the quality of institutions, geography, industrial structure and so on, they share many similarities with developing countries concerning the determinants and impacts of FDI on local firms.

Second, the book suggests that there are indeed huge spillover potentials from FDI. From Hungary to Brazil, from Indonesia to South Africa, we find evidence of technology transfer, learning and upgrading in the relationship between MNCs and local firms. Indeed, as some authors have argued, from a development perspective these spillover effects may be the single most important contribution that MNCs may have made to economic development. The studies have further documented how these spillovers may occur sometimes through arms-length relations, sometimes through more or less intense collaboration. However, a key message coming out of the studies is that spillovers do not occur automatically and under any circumstances. Indeed, the main message of the book is that spillovers are highly context dependent. Spillover dynamics thus vary enormously between countries, industries and MNCs. Moreover, different linkage practices may moderate the spillover effects of FDI. 
Third, the chapters have contributed to the literature on spillovers regarding specific aspects, for example the importance (or rather lack of importance) of clusters, the role of linkages, the constraints and limitations on spillovers provided by global value chain dynamics, the importance and limitations of policyinduced spillovers. In this way, the contributions of this book bring the literature forward and add to the accumulated knowledge in the field.

Fourth, the book suggests that the four main factors that we have indentified in section five interact and determine the magnitude of spillovers:

Industry factors: the rules of the game vary from industry to industry and contribute to determine the nature of linkages between MNCs and indigenous firms. Whereas in the metalworking industry in Indonesia MNCs have actively developed their local embeddedness, MNCs have only very limited linkages in the business services industry in Hungary. Global value chains' perspectives have introduced an interindustrial comparative approach and contributed to a better understanding of the mode of governance of different value chains (automobile, electronics, garments and so on). Yet the empirical material remains poor on services activities. Further research should focus on the spillovers of services activities in developing countries and transition economies, and assess the impact of MNCs in services compared to manufacturing activities. Do services open new upgrading opportunities in countries in which spillovers in manufacturing activities have been disappointing? The technological intensity of the industry also matters. The spillover potential should be particularly high in high-technology industries, especially in clusters. Yet in Poland and Romania, the presence of spillovers in high-technology industries has not been detected. There is clearly a dilemma between the easy-to-achieve but limited spillover potential of lowtechnology activities and the difficult-to-achieve but high spillover potential of high-technology activities. Further research needs to address this dilemma by entering into the 'black box' and focusing on the specific capacities that prevent local companies from benefiting from advanced technology.

Strategies of MNCs: International Business studies have largely demonstrated that the 'genetic code' and the strategy of the MNC also determine spillovers. This 'code' results from several factors such as the nationality of the firm, its competitive advantages, its history, and so on. In this book it has been suggested, for example, that the Japanese company Komatsu has actively developed its production linkages with the Tegal metal workshops. Since some companies have a developmental attitude whereas others tend to limit their interaction with local firms, further research might break up the strategies to assess the common features of the 'spillover-MNCs'.

Country factors: the limited absorption capacities by local firms of new management practices and technology, appears clearly in all the chapters of the book 
as the Achilles' heel for spillovers in developing countries, but also in transition economies. Local firms fail to adopt new technology or practices when they do not attain a certain threshold of development and/or when technology is too sophisticated. Several factors such as financial constraints, insufficient human capital and failing institutions interact and limit the learning potential of developing countries. Part III of the book also suggests that the quality of FDI policies matters. FDI open-doors policies and generous incentive packages do not support spillovers. Since spillovers are a catalyst for development, this book suggests that policies aiming at promoting MNCs-local firms relationships should be a priority in the upgrading agenda of developing countries and transition economies. Moreover, spillovers have idiosyncratic characteristics and de facto policymakers should adapt policies ex ante and ex post to the three dimensions: industry, strategy of the MNCs and host country endowments. As a consequence, and this is indeed a key message of the policy-oriented chapters of the book, any policy measures to promote spillovers should carefully scrutinize the specific context in which these measures are adopted.

Nature of linkages: Part II and III of the book confirm that the quality, quantity and scope of linkages shape spillovers. Long-term collaboration and repetitive interaction between MNCs and local firms foster spillovers in the host economy. Trust is a decisive factor for the diffusion of spillovers. The number of connections of MNCs with local companies as well as the value added by local firms are also decisive. Scarce backward and forward linkages are most of the time responsible for poor spillovers. Finally, dense collaboration with companies and institutions in host countries increases the developmental impact in the host country. Yet most of the time, even in emerging economies (by comparison to the other developing countries and transition economies), the technology gap prevents MNCs from developing their collaboration with local entities.

\section{Notes}

I 'Emerging economies' are defined as countries with rapid growth but low income using economic liberalization as a primary engine of growth. They encompass the developing countries of Asia, Latin America, the Middle East and Africa as well as the transition economies of mainly Central and Eastern Europe.

2 There is a conceptual ambiguity in much of the literature concerning the exact relation between linkages and spillovers (Giroud and Scott-Kennel, 2009). Thus, there is a tendency to view any effect of linkage collaborations between MNCs and local firms as spillovers. However, linkages are typically planned and contract-based and the value of the transaction is more or less fully appropriated by the transacting parties. Strictly speaking such effects are not 'spillovers', if spillovers are understood as positive externalities from a market transaction. The confusion of spillover effects and other effects deriving from linkage col- 
laborations is probably due to the fact that researchers typically are unable to untangle the spillover effect from the direct effect at the aggregate level (Giroud and Scott-Kennel, 2009).

3 Yet in reality, each vertical multinational has some horizontal features and horizontal firms do not replicate the totality of activities of the headquarter.

4 More recently, International Business has taken an interest in spillovers insofar as they have implications for the conduct and performance of MNCs. The prospects of large spillovers may ease approval of large investment projects and a MNC's reputation and brand may gain from strong spillover performance.

\section{List of references}

Aitken B., G.H. Hanson and A.E. Harrison (1997) 'Spillovers, Foreign Investment, and Export Behavior', Journal of International Economics 43(I-2), I03-132. Aitken B. and A.E. Harrison (1999) 'Do Domestic Firms Benefit from Direct Foreign Investment? Evidence from Venezuela', American Economic Review 89, 605-6i 8 .

Akbar Y.H. and J.B. McBride (2003) 'Multinational Enterprise Strategy, Foreign Direct Investment and Economic Development: The Case of the Hungarian Banking Industry', Journal of World Business 39(I), 89-105.

Alfaro L. (2003) 'Foreign Direct Investment and Growth: Does the Sector Matter?', Harvard Business School Working Paper April, Harvard Business School, Boston.

Aliber R.Z. (I97I) 'The Multinational Enterprise in a Multiple Currency World', in Dunning J.H. (ed.) The multinational enterprise, Allen \& Unwin, London.

Altenburg T. (2000) 'Linkages and Spillovers between Transnational Corporations and Small and Medium-Sized Enterprises in Developing Countries - Opportunities and Policies', in UNCTAD (ed.) MNC-SME Linkages for Development. Issues - experiences - best practices. Proceedings of the Special Round on MNCs, SMEs and Development, UNCTAD X, I5 February, 3-6I, Bangkok, United Nations, Geneva.

Ayyagari M. and R. Kosova (2006) 'Does FDI Facilitate Domestic Entrepreneurship? Evidence from the Czech Republic', Working Paper ot the George Washington University, Washington, DC.

Bain J. (1956) Barriers to New Competition, Harvard University Press, Cambridge. Balasubramanyam V.N., M.A. Salisu and D. Sapsford (1996) 'Foreign Direct Investment and Growth in EP and IS Countries', The Economic Journal Io6(434), 92-I05.

Blalock G. and P.J. Gertler (2007) 'Welfare Gains from Foreign Direct Investment through Technology Transfer to Local Suppliers', Journal of International Economics 74(2), 402-42I. 
Blomström M., A. Kokko and M. Zejan (1994) 'Host Country Competition and Technology Transfer by Multinationals', Weltwirtschaftliches Archiv 130, 521-533. Blomström M. and A. Kokko (1997) 'The Impact of Foreign Investment on Host Countries: A Review of the Empirical Evidence', World Bank Policy Research Working Paper 1745, World Bank, New York.

Blomström M. and A. Kokko (2000) 'Multinational Corporations and Spillovers', in Blomström M., A. Kokko and M. Zejan (eds.) Foreign Direct Investment: Firm and Host Country Strategies, Palgrave Macmillan, London.

Blomström M. and A. Kokko (2003) 'The Economics of Foreign Direct Investment Incentives', CEPR Discussion Paper 3775, London.

Blomström M. and H. Pearson (1983) 'Foreign Investment and Spillover Efficiency in Underdeveloped Economies: Evidence from Mexican Manufacturing Industry', World Development II(6), 493-50I.

Blyde J., M. Kugler and E. Stein (2004) 'Exporting vs. Outsourcing by MNC Subsidiaries: Which Determines FDI Spillovers?', Discussion Paper in Economics and Econometrics 4II, University of Southampton.

Borensztein E., J.D. Gregorio and J.-W. Lee (1998) 'How Does Foreign Direct Investment Affect Economic Growth?', Journal of International Economics 45(I), II5-I35.

Bosco M.G. (200I) 'Does FDI Contribute to Technological Spillovers and Growth? A Panel Data Analysis of Hungarian Firms', Transnational Corporations IO(I), 43-67.

Buckley P. and M. Casson (1976) The Future of the Multinational Enterprise, Macmillan, London.

Buckley P. and P. Ghauri (2002) 'Globalization, Economic Geography and the Strategy of MNEs', Journal of International Business Studies 35, 8I-98.

Cantwell J. and R. Narula (200I) 'The Eclectic Paradigm in the Global Economy', International Journal of the Economics of Business 8(2), 155-172.

Caves R.E. (197I) 'International Corporations: The Industrial Economics of Foreign Investment', Economica 38, I-27.

Caves R.E. (1974) 'Multinational Firms, Competition, and Productivity in HostCountry Markets', Economica 4I(I-2), I76-I93.

Caves R.E. (1996) Multinational Firms and Economic Analysis, Cambridge University Press, Cambridge.

Chan V.-L. (2000) 'FDI and Economic Growth in Taiwan's Manufacturing Industries', in Takatoshi I. and A.O. Krueger (eds.) The Role of Foreign Direct Investment in East Asian Economic Development, 349-366, Chicago University Press, Chicago.

Cohen W.M. and D.A. Levinthal (1990) 'Absorptive Capacity: A New Perspective on Learning and Innovation', Administrative Science Quarterly 35, I28-I52. 
Cypher J. and J. Dietz (2004) The Process of Economic Development, Routledge, London.

Damijan J., M. Knell, B. Majcen and M. Rojec (2003) 'Technology Transfer through FDI in Top-Io Transition Countries: How Important are Direct Effects, Horizontal and Vertical Spillovers?', William Davidson Institute Working Paper 549, University of Michigan, Ann Arbor.

De Mello L. (1999)'Foreign Direct Investment-Led Growth: Evidence from Time Series and Panel Data, Oxford Economic Papers 5I(I), I33-I5I.

De Propis L. and N. Driffield (2005) 'The Importance of Clusters for Spillovers from Direct Investment and Technology Sourcing', Cambridge Journal of Economics 30(2), 277-291.

Dicken P. (2003) Global Shift, Sage, London.

Djankov S. and B. Hoekman (2000) 'Foreign Investment and Productivity Growth in Czech Enterprises', World Bank Economic Review I4(I), 49-64.

Dobson W. and S.W. Chia (eds.) (1997) Multinationals and East Asian Integration, International Development Research Center, Ottawa, Canada.

Dunning J.H. (198I) International Production and the Multinational Enterprise, Allen \& Uwin, London.

Dunning J.H. (1988) 'The Eclectic Paradigm of International Production: A Restatement and Some Possible Extensions', Journal of International Business Studies I9(I), I-3I.

Dunning J.H. (1997) Alliance Capitalism and Global Business, Routledge, London.

Dunning J.H. (200I) 'The Eclectic (OLI) Paradigm of International Production: Past, Present and Future', Journal of Economics of Business 8(2), 173-190.

Dunning J.H. and R. Narula (2004) 'Industrial Development, Globalization and Multinational Enterprises: New Realities for Developing Countries', in Dunning J.H. and R. Narula (eds.) Multinationals and Industrial Competitiveness, Edward Elgar, Cheltenham.

Enderwick P. (2005) 'Attracting Desirable FDI: Theory and Evidence', Transnational Corporations I4(2), 93-I20.

Forsgren M. (2002) 'Are Multinational Firms Good or Bad?', in Havila V., M. Forsgren and $\mathrm{H}$. Hakansson (eds.) Critical Perspectives on Internationalization, Pergamon, London.

Gerschenkron A. (1962) Economic Backwardness in a Historical Perspective, Harvard University Press, Cambridge.

Gereffi G. (1999) 'International Trade and Industrial Upgrading in the Apparel Commody Chain', Journal of International Economics 48(I), 37-70.

Gereffi G. and M. Korzeniewicz (eds.) (1994) Commodity Chains and Global Capitalism, Praeger, Westport. 
Gereffi G., J. Humphrey and T. Sturgeon (2005) 'The Governance of Global Value Chains', Review of International Political Economy ${ }_{11}(\mathrm{I}), 13-33$.

Giroud A. and J. Scott-Kennel (2006) 'Foreign-Local Linkages in International Business: A Review and Extension of the Literature', Academy of International Business Conference, Beijing, 23-26 June.

Giroud A. (2007) 'MNEs Vertical Linkages: The Experience of Vietnam after Malaysia', International Business Review I6(2), 159-176.

Giroud A. and J. Scott-Kennel (2009) 'MNE Linkages in International Business: A Framework for Analysis', International Business Review 18, 555-566.

Görg H. and D. Grenaway (2004). 'Much Ado about Nothing? Do Domestic Firms Really Benefit from Foreign Direct Investment?', World Bank Research Observer 19, I7 I-197.

Görg H. and E. Stobl (200I) 'Multinational Companies and Productivity Spillovers: A Meta-Analysis', Economic Journal III(475), 723-739.

Ghoshal S. and C.A. Bartlett (1990) 'The Multinational Corporation as an Interorganizational Network', The Academy of Management Review 15(4), 603625.

Haddad M. and A. Harrison (1993) 'Are There Positive Spillovers from Direct Foreign Investment? Evidence from Panel Data for Morocco', Journal of Development Economics 42, 51-74.

Halpern L. and B. Muraközy (2005) 'Does Distance Matter in Spillover?', Discussion Paper of the Center for Economic Policy Research 4857, London.

Hansen M.W. and H. Schaumburg-Müller (eds.) (2006) Transnational Corporations and Local Firms in Developing Countries - Linkages and Upgrading, Copenhagen Business School Press, Copenhagen.

Hansen M.W., T. Pedersen and B. Petersen (2009) 'MNC Strategies and Linkage Effects in Developing Countries', Journal of World Business 44(2), I2I-I3I.

Hein S. (1992) 'Trade Strategy and Dependency Hypothesis: A Comparison of Policy, Foreign Investment, and Economic Growth in Latin America', Economic Development and Cultural Change 40(3), 495-521.

Helpman E. (1984) 'A Simple Theory of International Trade with Multinational Corporations', Journal of Political Economy 92, 451-472.

Helpman E. and P. Krugman (1985) Market Structure and International Trade, MIT Press, Cambridge.

Hirschman A.O. (1958) The Strategy of Economic Development, Yale University Press, New Haven.

Humphrey J. and O. Memedovic (2003) 'The Global Automotive Industry Value Chain: What Prospects for Upgrading by Developing Countries', Sectoral Studies Series, United Nations Industrial Development Organization, Geneva. 
Hymer S. (1976 [1960]) The International Operations of National Firms: A Study of Foreign Direct Investment, Ph.D. Dissertation, MIT Press, Cambridge.

Javorcik B. (2004) 'Does Foreign Direct Investment Increase the Productivity of Domestic Firms? In Search of Spillovers through Backward Linkages', American Economic Review 94, 605-627.

Javorcik B. and M. Spatareanu (2008) 'To Share or not to Share: Does Local Participation Matter for Spillovers from Foreign Direct Investment?', Journal of Development Economics 85(I-2), 194-217.

JBIC Institute (2002) 'Foreign Direct Investment and Development: Where Do we Stand?' JBIC Resarch Paper 15, Japan Bank for International Cooperation, Tokyo.

Jiang X., L. Lee, Q. Shen and S. Wang (2005) A Comparative Study of Regional Development Strategies in China's Electronics Sector, Mimeo, Berkeley University.

Kapur D., R. Ramamurti and D. Moitra (200I) 'India's Emerging Competitive Advantage in Services', Academy of Management Executive I5(2), 20-33.

Kogut B. and U. Zander (2003) 'Knowledge of the Firm and the Evolutionary Theory of the Multinational Corporation', Journal of International Business Studies 34(6), 516-530.

Kojima K. (1973) 'A Macroeconomic Approach to Foreign Direct Investment', Hitotsubashi Journal of Economics June, I-2I.

Kokko A., R. Tansini and M.C. Zejan (1996) 'Local Technological Capability and Productivity Spillovers from FDI in the Uruguayan Manufacturing Sector', Journal of Development Studies 32(4), 602-61I.

Kokko A., M. Zejan and R. Tansini (200I)'Trade Regimes and Spillovers Effects of FDI: Evidence from Uruguay', Review of World Economics 137(I), I24-I49.

Konings J. (2000) 'The Effect of Direct Foreign Investment on Domestic Firms: Evidence from Firm Level Panel Data in Emerging Economies', William Davidson Working Paper 344, University of Michigan, Ann Arbor.

Kugler M. (2000) 'The Diffusion of Externalities from Foreign Direct Investment: Theory Ahead of Measurement', Discussion Papers in Economics and Econometrics 23, University of Southampton.

Larsen M.N., P. Yankson and N. Fold (2009) 'Does FDI Create Linkages in Mining? The Case of Gold Mining in Ghana', in E. Rugraff, D. Sanchez-Ancochea and A. Sumner (eds.) Transnational Corporations and Development Policy: Critical Perspectives, 247-273, Palgrave MacMillan, London.

Lin P. and K. Saggi (2007) 'Multinational Firms, Exclusivity and Backward Linkages', Journal of International Economics 7I(I), 206-220.

Lipsey R.E. and F. Sjöholm (2004) 'FDI and Wage Spillovers in Indonesian Manufacturing', Review of World Economics I4O(2), 32I-332. 
Lipsey R.E. and S. Sjöholm (2005) 'The Impact of Inward FDI on Host Countries: Why Such Different Answers?', in T. Moran, E. Graham and M. Blomström (eds.) Does Foreign Investment Promote Development?, 23-43, Institute for International Economics, Washington, DC.

MacDougall G.D.A. (1960) 'The Benefits and Costs of Private Investments from Abroad: A Theoretical Aapproach', Economic Record 36, I5-35.

Markusen J.R. (1984) 'Multinationals, Multi-Plant Economies, and the Gains from Trade', Journal of International Economics 16, 205-226.

Markusen J.R and A.J. Venables (1999) 'Foreign Direct Investment as a Catalyst for Industrial Development', European Economic Review 43, 335-356.

Merlevede B. and K. Schoors (2005) 'FDI and the Consequences: Everything Policymakers Always Wanted to Know about Spillovers but Were Afraid to Ask', Working Paper of Ghent University 12, Belgium.

Meyer K.E. (2004) 'Perspectives on Multinational Enterprises in Emerging Economies', Journal of International Business Studies 35(4), 259-276.

Moran T. (2002) 'Beyond Sweatshops: Foreign Direct Investment and Globalization in Developing Countries', Brookings Institution, Washington, DC.

Moran T., E. Graham and M. Blomström (eds.) (2005) Does Foreign Investment Promote Development?, Institute for International Economics, Washington, DC. Narula R. and J.H. Dunning (2000) 'Industrial Development, Globalisation and Multinational Enterprises: New Realities for Developing Countries', Oxford Development Studies 28, I4I-167.

Narula R. and S. Lall (2004) 'Foreign Direct Investment and its Role in Economic Development: Do We Need a New Agenda?', The European Journal of Development Research 16(3), 447-464.

Nunnenkamp P. and J. Spatz (2003) 'Foreign Direct Investment and Economic Growth in Developing Countries: How Relevant Are Host-Country and Industry Characteristics?', Kiel Working Paper II76, Kiel University.

Nunnenkamp P. (2004) 'To What Extent Can Foreign Direct Investment Help Achieve International Development Goals?', The World Economy 27 (5), 657-677.

Pavlinek P. (2005) A Successful Transformation? Restructuring of the Czech Automobile Industry, Physica-Verlag, Heidelberg.

Pearce R. and M. Papanastassiou (1999) 'Overseas R\&D and the Strategic Evolution of MNEs: Evidence from Laboratories in the UK', Research Policy 28(I), 23-4I.

Peteraf M.A. (1993) 'The Cornerstones of Competitive Advantage: A ResourceBased View', Strategic Management Journal I4(I), I79-19I.

Porter M.E. (1986) 'Competition in Global Industries: A Conceptual Framework', in M.E. Porter (ed.) Competition in Global Industries, Harvard Business School, Cambridge. 
Prahalad C.K. and G. Hamel (1990) 'The Core Competencies of the Corporation', Harvard Business Review May-June, 79-9I.

Reuber G.I. (1973) Private Investment in Development, Clarendon Press, Oxford.

Rhee Y.W. and T. Belot (1990) 'Export Catalysts in Low-Income Countries', World Bank Discussion Paper 72, The World Bank, Washington.

Rodriguez-Clare A. (1996) 'Multinationals, Linkages and Economic Development', American Economic Review 86(4), 852-873.

Rodrik D. (1999) The New Global Economy and Developing Countries: Making Openness Work, Overseas Development Council, Washington, DC.

Rugman A.M. (198I) Inside the Multinationals: The Economics of Internal Markets, Croom Helm, London.

Rugraff E. (2008) 'Are the FDI policies of Central European countries efficient?', Post-Communist Economies 20(3), 303-316.

Rugraff E., D. Sanchez-Ancochea and A. Sumner (eds.) (2009) Transnational Corporations and Development Policy-Critical Perspectives, Palgrave MacMillan, London.

Schoors K. and B. van der Tol (2002) 'Foreign Direct Investment Spillovers Within and Between Sectors: Evidence from Hungarian Data', Working Paper 2/157, University of Gent.

Scott-Kennel J. and P. Enderwick (2005) 'FDI and Inter-Firm Linkages: Exploring the Black Box of the Investment Development Path', Transnational Corporations $\mathrm{I} 4(\mathrm{I}), \mathrm{I} 3-23$.

Sgard J. (200I) 'Direct Foreign Investments and Productivity Growth in Hungarian Firms, 1992-I999', CEPII Working Paper 19, Paris.

Singer H. (1950) 'The Distribution of Gains Between Investing and Borrowing Countries', American Economic Review 40, 473-485.

Singh R.D. (1988) 'The Multinational's Economic Penetration, Growth, Industrial Output, and Domestic Savings in Developing Countries: Another Look', Journal of Development Studies 25(I), 55-82.

Spar D. (2008) 'National Policies and Domestic Politics', in A.M. Rugman (ed.) The Oxford Handbook of International Business, 205-225, Oxford University Press, New York.

Spar D. and D. Yoffie (1999) 'Multinational Enterprises and the Prospect for Justice', Journal of International Affairs 52, 557-58I.

Sturgeon T.J. (2008) 'Mapping Integrative Trade: Conceptualising and Measuring Global Value Chains', International Journal of Technological Learning, Innovation and Development I(3), 237-257.

Sturgeon T.J. and R.K. Lester (2003) 'The New Global Supply-Base: New Challenges for Local Suppliers in East Asia', MIT Special Working Papers Series 03-006, MIT Industrial Performance Center, Cambridge. 
Tavares A.T. and S. Young (2005) 'FDI and Multinationals: Patterns, Impacts and Policies', International Journal of the Economics of Business I2(I), 3-16.

Thompson E.R. (2002) 'Clustering of Foreign Direct Investment and Enhanced Technology Transfer: Evidence from Hong Kong Garment Industry in China', World Development 30(5), 873-889.

UNCTAD (1992) World Investment Report: Transnational Corporations as Engine of Growth, United Nations, New York.

UNCTAD (1998) World Investment Report: Trends and Determinants, United Nations, New York.

UNCTAD (1999) World Investment Report: FDI and the Challenges of Development, United Nations, New York.

UNCTAD (2000) 'Enhancing the competitiveness of SMEs through linkages', Background Paper prepared by the UNCTAD Secretariat TD/B/COM.3/ EM.11/2, United Nations, New York.

UNCTAD (200I) World Investment Report: Promoting Linkages, United Nations, New York.

UNCTAD (2004) World Investment Report: Services, United Nations, New York.

UNCTAD (2005) World Investment Report: R\&D, United Nations, New York.

UNCTAD (2009) World Investment Report: Transnational Corporations, Agricultural Production and Development, United Nations, New York.

UNCTAD (2010) World Investment Report: Investing in a Low-Carbon Economy, United Nations, New York.

Wilkins M. (1998) 'Multinational Corporations: An Historical Account', in R. Kozul-Wright and R. Rowthorn (eds.) Transnational Corporations and the Global Economy, 95-125, Macmillan Press, London.

Zahra A. and G. George (2002) 'Absorptive Capacity: A Review, Reconceptualization, and Extension Shaker', The Academy of Management Review 27(2), 185-203. 



\section{Part II}

Studies of Spillovers and linkages BETWEEN MULTINATIONAL CORPORATIONS AND LOCAL FIRMS 



\title{
2 The impact of foreign direct investment in business services on the local economy
}

\author{
The case of Hungary
}

Magdolna Sass

\section{I Introduction}

East Central Europe and within it Hungary are locations where, especially starting from 2000, more and more independent business services firms ${ }^{1}$ set up their operations and many firms concentrated their regional, European or even global service center. For example, in Hungary independent firms such as EDS, SAP, GenPact, Diageo and IBM are present. As for the second group, Alcoa, Vodafone, Exxon Mobil, Avis, Cemex, GE, InBev, Morgan Stanley, Celanese, Lexmark, British Telecom, among others, relocated certain regional, European or global service functions to Hungary. Not only the number of projects grew significantly, but there were also some very big projects involved, employing thousands of new employees in their newly opened sites (see for example Gál, 2007; Sass, 2008a; $2008 \mathrm{~b}$ ). In many cases, these service functions are transferred from other, usually Western European locations, causing white collar job losses there. This is one reason why these movements figure highly in the (Western) media.

Offshore outsourcing and offshoring of service activities is not a new phenomenon (Metters and Verma, 2007). After and parallel to outsourcing/offshoring the low- and medium-skilled production processes in manufacturing, starting mainly from the I990s, the offshoring and offshore outsourcing of certain production processes of specific services from developed countries to other developed or developing countries has started to become more and more widespread (UNCTAD, 2004). The process has been induced by technological development - in many various ways. As a result of technology developments, the fragmentation, division, standardization, 'algorithmization' of services processes, evaluation of certain service process elements, digitalization, and the coding of information were made possible. This is similar to the fragmentation process in manufacturing, but on the basis of available evidence, the fragmentation can go deeper in services processes. After such fragmentation, certain service processes can be separated and they can 
be carried out in locations where it is cheaper, more efficient, or where it provides better quality. As a result, certain services became tradable, even internationally. Information and communication technologies made mainly services dealing with information tradable. It is now possible to produce certain services in far away locations and consume them in another far away location at the same time, or even at different times (UNCTAD, 2004). Information and Communication Technology (ICT) developments also allowed reducing the response time (Metters and Ver$\mathrm{ma}, 2007$ ). New goods appeared which acted as 'mediators' (for example compact discs, software) in services trade (Lindner et al,, 200I). The outsourcing of services has also been helped by the ongoing uni-, bi- and multilateral liberalization process of the services trade, although the level of liberalization does not reach that of manufacturing goods (UNCTAD, 2004). 'Unilateral' changes in relevant governmental regulations and incentives, with the aim of proactively attracting offshore business services, also played a role. This can be traced in investments in telecommunications infrastructure, and in more and more countries offering tax allowances for such types of activities (Metters and Verma, 2007). Increased presence of global networks also contributed to the process (Dicken, 2003; Netland and Alfnes, 2007). Other specific factors, such as for example the acceptance of English as lingua franca, general institutional compatibility and adaptability, simpler logistics in services compared to manufacturing, also played a role in the quick advancement of the process (Bardhan and Kroll, 2003, p.3).

The services functions affected include a heterogeneous group of activities such as various computer services, legal, finance, accounting, marketing services, a range of $R \& D$ processes, certain medical and cultural services and so on. Table 2.I shows the categories used in describing these processes. In this chapter we concentrate on captive offshoring and offshore outsourcing. Offshoring and offshore outsourcing refer to a company's decision to transfer certain activities, which were hitherto carried out inside the company, to another unit of the firm in a foreign location (captive offshoring) or to an independent firm (offshore outsourcing). Business process outsourcing describes a relationship between a vendor and a client, where the vendor performs an entire business service function for the client (this definition is based on Chakrabarty, 2006, p. 35).

Table 2.1 Categories used in the analysis

\begin{tabular}{lll}
\hline Location of production & Internalized & Externalized (outsourcing) \\
\hline Home country & $\begin{array}{l}\text { Production kept in-house at } \\
\text { home }\end{array}$ & Outsourcing (at home) \\
\hline Foreign country (offshoring) & Intrafirm (captive) offshoring & Offshore outsourcing \\
\hline
\end{tabular}

Source: based on UNCTAD, 2004, p. 148 
As far as the geographical dimension of the phenomenon is concerned, the process of services outsourcing started in the USA, then other Anglo-Saxon countries (first of all Great-Britain) followed. While certain activities started to be outsourced as early as in the 1950s, the process itself accelerated and became widespread only in the 1990s (Metters and Verma, 2007). Countries (or rather companies) of continental Europe followed these two countries later, and they are in the process of catching up with the first movers. This can be explained not only by a slower reaction, a different culture within continental European companies or higher obstacles to offshoring and outsourcing, but also by the language barriers existing for 'smaller' European languages. ${ }^{2}$ Moreover, in many cases they prefer 'nearshoring', that is to say, keeping the relocated functions close to the original site. ${ }^{3}$ On the receiving end, as 'mirroring' home countries and reflecting the dominance of the English language, Anglo-Saxon culture and other common elements (for example the common law structure, see Bardhan and Kroll, 2003, p. 3) - Ireland, India, Canada and Israel are the most important destinations (UNCTAD, 2004). In Europe, traditionally, Ireland is the most important host country, but other 'old' EU-member countries also have a relatively high market share (first of all Great-Britain, Portugal and Spain are important host countries) (UNCTAD, 2004).

All in all, the overwhelming majority of services offshore outsourcing and captive offshoring is still realized between developed countries, though certain developing countries, especially India, are becoming important players. The role of the new member states of the European Union is becoming increasingly important; however, their market shares are still very small. Because of methodological problems, it is not easy to prove this statement. Statistical data on services foreign trade, FDI or jobs can not be used to describe international developments and characteristics of the process (Sass, 2009). Estimations which are available are usually prepared by industry experts or consulting firms and are based on company surveys and interviews (Kirkegaard, 2005, p. 5). According to the data of UNCTAD (2004), one third of the services outsourcing projects of European multinational companies went to India. Western European countries (Ireland, Portugal, Spain and Great-Britain) had a $29 \%$ share, and $22 \%$ of the projects went to East-Central and Eastern Europe, mainly to Hungary, Poland and Romania. Because larger projects go to India, this country's share can be close to $50 \%$ in terms of market share. According to McKinsey \& Company, the share of the East-Central European region from global business services was as low as $\mathrm{I} \%$ in 2005. Thus, the region is left behind the leading Asian countries, but the later start of European companies indicates that the process is only about to take off for the East-Central European region. According to the survey conducted by IBM and Oxford Intelligence, East-Central Europe - besides Ireland - is already 
the location of pan-European service centers, that is, companies in Continental Europe are supplied from here. Altogether, the role of East-Central Europe is growing, though it is not as big as one could expect on the basis of the information presented by the (Western) media.

Hungary has been one of the leading locations in attracting business services projects in the East-Central European region. Services centers appeared already during the I990s, partly because Hungary opened up its economy to FDI the earliest and it has been a major destination of Western FDI in the region. Affiliates of multinational corporations operating in the country provided the demand for business services, which in itself attracted such projects. Moreover, as an attracting factor, relevantly skilled labor with competitive wages, the legal and physical (especially ICT) infrastructure and office space have been available in the required quality and quantity similarly to other countries in the region. The number of such centers can be around 50 at present and the number of jobs created around 20,000 , according to 2008 data. This represents more than $0.5 \%$ of total employment and almost $\mathrm{I} \%$ of services employment in Hungary. ${ }^{4}$

This chapter analyzes the impact of business services projects on the Hungarian economy. First, it presents the relatively scarce results in the literature concerning the evolution and impact of business services FDI generally and in the region. Second, based on eight company interviews taken in Hungary during 2008, it describes channels and importance of local impact of FDI in business services. Third, the policy environment surrounding these projects is shortly described. Fourth, the last part summarizes the most important findings.

\subsection{Review of the literature and analytical framework}

Offshoring and offshore outsourcing of business services offer various advantages and disadvantages for the host country as well. Because almost all related projects in East-Central Europe and in Hungary involve the presence of multinational corporations (MNCs), our analytical framework relies on Barba Navaretti and Venables (2004). Host country impacts of MNCs can be grouped in three categories: product market effects, factor market effects and spillover effects. The relative importance of these impacts depends on the nature of FDI, whether it is vertical or horizontal, and on the characteristics of the host country (Barba Navaretti and Venables, 2004). Moreover, it depends on the special characteristics of the sector, in this case on those of business services. 
Table 2.2 Effects of MNCs on host countries

\begin{tabular}{lll}
\hline Where do the effects arise? & \multicolumn{2}{c}{ Effects } \\
\hline Product markets & Host & Home \\
\hline Factor markets & Productivity differences & Productivity differences \\
& Competition and market supply & Output levels \\
\hline Spillovers & Skills & Employment and wages \\
& Volatility & Skills \\
& Transmission of technology & Technological sourcing \\
& Transmission of intangible & \\
& effects & \\
& Pecuniary externalities & \\
\hline
\end{tabular}

Source: Barba Navaretti and Venables, 2004

In this chapter we analyze in detail the impact of FDI in business services on the host economy, based on the experiences of Hungary. There are not many precedents in analyzing this topic. There is little written about the impact of services FDI: academic studies usually concentrate on offshoring and offshore outsourcing in the manufacturing sector (van Gorp et al., 2006, p. 3). Moreover, the literature concentrates mainly on (developed) home country impacts, especially in terms of job losses and welfare implications, as well as home country firm strategies for outsourcing (Hansen et al., 2007, p. 4). There is little written about the 'supply side' of international fragmentation in services (Grover, 2007). Even analyses concerning home country impacts are somehow one-sided. They concentrate on the negative impact on the home country factor market in terms of changes in employment and wages. While there are many studies concerning the job loss and wage impact in the Western part of Europe (or in the USA) due to globalization, and thus due to the changing nature of distribution of manufacturing and service activities (see among others Geishecker, 2002; 2005; Egger and Egger, 2003; 2005; Marin, 2004; Schöller, 2007; Geishecker et al., 2007; Gianelle and Tattara, 2007), there is basically no information or estimate about the number of jobs created in both parts of Europe due to that process (Jensen et al., 2006, p. 2). Analysis of the impact of services offshoring and offshore outsourcing on the host economies, especially in Central and Eastern Europe is basically missing.

There is also little written about business services in Hungary. The few existing papers describe the main processes, based mainly on the analysis of available statistical data or using information published by consulting firms. These papers agree on the increasing importance of this kind of services in the Hungarian economy and the role of FDI in it (see for example Hamar, 2005; Bajmócy, 2007; 
Gál, 2009; Sass, 2008a.). Hamar (2005) also calls attention to the problems of measurability and lack of data, which limits our knowledge about the sector.

It was already mentioned that there are many definition, data and methodological problems in analyzing the characteristics of offshoring and offshore outsourcing of business services (see for example Sass, 2009; or for services overall, Francois and Hoekman, 2009). Experts examining these data problems in detail suggest that the best approach in this field is to supplement existing quantitative analysis with more qualitative examinations and to combine quantitative and qualitative research (Sturgeon et al., 2006). This instruction is basically followed in this chapter as well: statistical data are used to provide some insights into the extent and role of these kinds of services in the host economy. Further analysis of the impact on the local economy and local firms is carried out using company case studies. Managers of eight companies were interviewed, of which four are independent service providers and four are captive centers. These eight companies represent about one fourth of total employment in the information technology (IT) and business services sector in Hungary, which rests upon the fact that the two biggest companies are involved. These eight company case studies do not provide a sufficient basis for making unchallengeable conclusions about the local impact of offshored and offshore-outsourced business services FDI in Hungary. However, in some respects, given the uniformity of the companies interviewed, certain common characteristics of these kinds of projects are reinforced.

\subsection{Foreign direct investment in business services in Hungary and channels of its local impact}

In Hungary, in terms of the relative share of output and value added, significant growth characterizes computer services, while other business activities show very little change (Table 2.3).

However, the share of these two subsectors in total services exports increased significantly, and the share of business services decreased in services imports. The trade balance of the two subsectors turned to positive from a slightly negative one (Table 2.4).5 Moreover, specialization indices turned positive for other business services, and converged to zero for computer and IT services (Sass, 2008b). Thus, in spite of all the methodological difficulties, a change in the relative importance of the two subsectors in the Hungarian economy and foreign trade is obvious. Similar developments are indicated for Romania (Ghibutiu and Dumitriu, 2008) showing an improving revealed comparative advantage (RCA) ${ }^{6}$ (approaching unity) in both subsectors vis-à-vis the EU-I5 and positive RCAs in 2006 vis-à-vis other new member countries of the EU. 
Table 2.3 Changes in the share of business services in total output and value added in Hungary

\begin{tabular}{lcc}
\hline \% in total & 1996 & 2006 \\
\hline Gross output & 10.1 & 11.2 \\
K Real estate, renting and business activities & 0.5 & 1.1 \\
72 Computer and related activities & 0.3 & 0.3 \\
73 Research and development & 5.1 & 4.9 \\
74 Other business activities & & \\
Gross value added & 13.4 & 15.4 \\
K Real estate, renting and business activities & 0.5 & 1.4 \\
72 Computer and related activities & 0.4 & 0.4 \\
73 Research and development & 6.0 & 6.1 \\
74 Other business activities &
\end{tabular}

Source: National Accounts of Hungary, Hungarian Central Statistical Office

Table 2.4 Changes in foreign trade of computer/IT services and other business services of Hungary

$19962006 \quad 2007$

$\%$ in total exports

\begin{tabular}{lrrr}
2.7 computer and IT services & 1.6 & 3.7 & 4.2 \\
2.9 other business services & 23.6 & 26.7 & 27.8 \\
\hline \% in total imports & & & \\
2.7 computer and IT services & 1.5 & 4.6 & 4.2 \\
2.9 other business services & 36.6 & 29.9 & 29.7 \\
\hline Balance (million euros) & & & \\
2.7 computer and IT services & 27 & -40 & 49 \\
2.9 other business services & -57 & 38 & 85
\end{tabular}

Source: Balance of payments, published by the National Bank of Hungary

Business services FDI (including computer and related activities) is mainly of a vertical nature, because parts of the service operation are transferred to a new location, while other parts remain on the original site. However, in business services horizontal FDI can also be present, as we shall see later. ${ }^{7}$ As far as product market effects are concerned, this type of FDI results mainly in the increase of the variety and quality of products, and through that impact, they may increase competition and displace domestic entrepreneurs and companies. However, this specific product is tradable and highly export oriented. Even previous to the ap- 
pearance of these companies, these types of business services (with the possible exception of computer services) were basically nonexistent in the country according to Western standards, and were mainly imported or were provided by partly or wholly foreign-owned service companies, which followed their clients to the new location. That is why this crowding-out effect is of smaller importance. We can identify two segments of the market: one with Hungarian-owned companies providing services to Hungarian-owned companies and the other one with foreign-owned companies providing services to foreign-owned clients. There is some overlap between the two, but they seem to operate in quite a separated way from each other. The impact of business services related FDI is much more important on factor markets, especially on the labor market. It increases the overall demand for labor, and it has a significant influence on the skill composition of that demand, since it increases demand for highly skilled employees. This may impact upon the development in relative factor prices - however, the analysis of this phenomenon is outside the scope of the present study. Spillover effects may take two distinct forms: those of technological and pecuniary externalities, because FDI goes together with costs and benefits which are not directly transmitted through the market (Barba Navaretti and Venables, 2004). Direct technology transfer is important in this case, as all companies use the highest level technologies and they also use high-quality management and production organization. Other types of effects, for example acquisition of labor skills concerning technology, managerial skills, know-how, knowledge about the markets and even 'business ethics' in a wide sense, and their transmission to local companies is an important channel through which these foreign-owned companies may have an impact upon the local economy. Pecuniary externalities may occur in this case through the use of local suppliers, including local services providers and through selling products to local companies (backward and forward linkages). This may result in an increase in the quantity and quality of local output, and in the increase in the productivity of local companies, through providing access to good quality services and opportunity to outsourcing certain services, and thus concentrating on core activities. Moreover, by its nature, this type of FDI has an impact on the balance of payments: a one-off impact on the capital balance, followed by further impacts if reinvestment of earnings is realized, and another impact on the current account by its export intensity. However, the analysis of this latter impact is seriously hindered by methodological problems and data limitations. Another instant gain and benefit for the host economy is from taxing the companies in question (Caves, 2007, p. 239). Here not only profit tax is important, but all other taxes, minus the extra costs (incentives, additional public services required to deal with foreign-owned companies). Here, due to lack of data, we do not deal with this latter type of impact. 
Using the categories presented in Table 2.2, on the basis of company interviews, the following main categories of impact on the host economy can be distinguished for export-oriented business services FDI.

\subsubsection{Raising demand for skilled labor}

First of all, it is important to determine what kind of activities are transferred to Hungary in export-oriented business services projects. It is obvious from the company interviews that the activities in question are very diverse, and the skill content of these activities varies from the least skill intensive to processes using the highest quality workforce. Even in the case of the same activity, the skill content may be different depending on the real content of the activity: for example a call center can provide basic information in one language, and more comprehensive information (for example IT support) in multiple languages.

Figure 2.1 Offshored services

\begin{tabular}{|c|c|c|c|c|}
\hline Back office & $\begin{array}{l}\text { Customer } \\
\text { contact }\end{array}$ & $\begin{array}{l}\text { Common } \\
\text { corporate } \\
\text { functions }\end{array}$ & $\begin{array}{l}\text { Knowledge } \\
\text { services and } \\
\text { decision analysis }\end{array}$ & $\begin{array}{l}\text { Research and } \\
\text { development }\end{array}$ \\
\hline \multicolumn{5}{|c|}{$\begin{array}{l}\longrightarrow \text { Increasingly complex transaction } \longrightarrow \\
\text { Sample functions }\end{array}$} \\
\hline $\begin{array}{l}\text { Basic data entry } \\
\text { - Applications } \\
\text { - Data } \\
\text { conversion } \\
\text { Transaction } \\
\text { processing } \\
\text { Document } \\
\text { management }\end{array}$ & \begin{tabular}{|l|} 
Customer relations \\
- Call centres \\
$\quad$ (in/outbound) \\
- On-line \\
service \\
Tele-marketing \\
Collections
\end{tabular} & \begin{tabular}{|l|} 
Shared corp. \\
services \\
- Finance/Acct. \\
- HR \\
- Procurement \\
- IT services \\
- ${ }^{*}$ Help-desk \\
$-{ }^{*}$ \\
Maintenance \\
- Applications
\end{tabular} & $\begin{array}{l}\text { Research services } \\
\text { Customer and } \\
\text { portfolio analysis } \\
\text { Process claims } \\
\text { Risk management } \\
\text { Credit } \\
\text { underwriting }\end{array}$ & \begin{tabular}{|l} 
Content \\
development, \\
engineering \& \\
design \\
New product \\
design \\
$\quad$ - Specs \\
$\quad$ - Prototypes \\
- Testing
\end{tabular} \\
\hline \multicolumn{5}{|c|}{$\longrightarrow \rightarrow$ Access to highly skilled labour pool } \\
\hline
\end{tabular}

Source: based on the scheme of McKinsey Global Institute

What kinds of jobs are offered and what kind of activities are carried out in these companies? This is the topic on which the interviewed companies are usually reluctant to give out any information. However, it is obvious, that two of the eight companies in the Hungarian sample carry out the most complex activities and belong to the fifth category in Figure 2.I. The other companies interviewed operate in a bunch of activities, comprising mainly functions described in the 
second, third and fourth boxes of Figure 2.I. In one of the interviewed companies, in one of its twenty plants, even activities belonging to the first box (transaction processing and document management) are also carried out, though this activity represents a very minor part of the activities of the company in question (around a dozen of close to 2,000 employees do that activity). Specific IT call centers are also operated by one of the companies, which can not be assessed as a 'simple' customer contact activity, because a higher level of IT-knowledge of the employee is a prerequisite. Except for the back-office activities, in all other jobs in Hungary, the knowledge of at least one foreign language is a prerequisite.

Figure 2.2 Activities carried out in the foreign-owned companies interviewed in Hungary

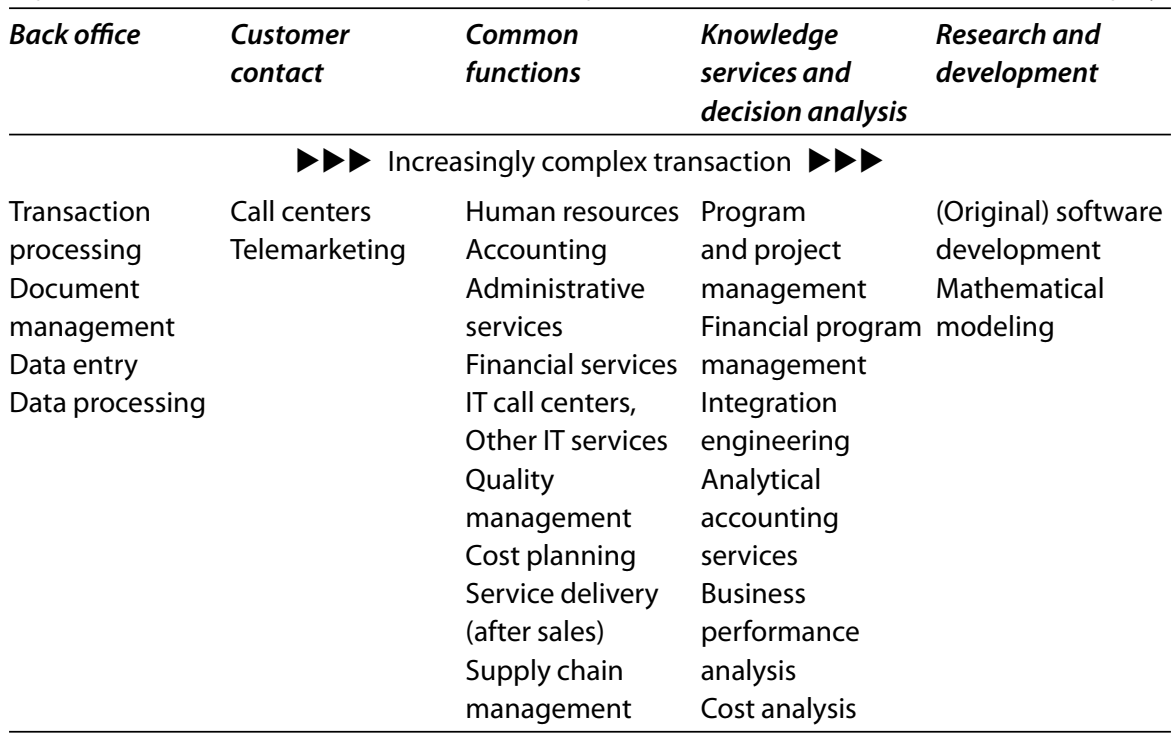

Source: Own compilation based on company interviews using the figure of McKinsey Global Institute

Altogether, on the basis of the company interviews, most of the activities carried out in Hungary belong to the medium- and medium-high skilled categories (Figure 2.2). To a certain extent, unskilled, intensive and high-skilled activities are also present, but medium-skilled ones dominate. Thus, service center and regional headquarter projects created a large number of mainly medium to highskilled jobs (according to Figure 2.I) in Hungary+ Just to give an estimation for the shares of various activities: the eight interviewed companies created approximately 5,500 jobs. Around a dozen of these belong to the lowest category and around 220 to the highest. All the remaining jobs can be considered as being of 
medium-high complexity. Altogether, according to various sources and estimations, in Hungary around 20,000 such jobs were created up till now. The overwhelming majority of these jobs is white collar (there was only one company case among those interviewed in Hungary, as was already mentioned, where a dozen of blue-collar jobs were involved among the total number of 2,000 jobs created). As for other characteristics of workers, the average age of employees in the interviewed companies is relatively low, below 30 years of age, and there are many for whom this is their first job after graduation, thus these projects contributed to the reduction of unemployment among fresh graduates. This seems to be a problem in other Central European countries as well with the possible exception of the Czech Republic. Between $80 \%$ and $90 \%$ of employees have a university diploma, the majority of them speak more than one foreign language. There is a gender aspect at the lower level of aggregation of services activities carried out in the interviewed companies: while engineers, software engineers and other computer-related services employees are predominantly men, human resources managers and accountants are mainly women. The picture is more mixed for call center workers; however, a slightly lower domination of women is also present there. Partly due to the strenuousness of certain job categories and to the high demand and relatively low supply of relevant workers, a relatively high attrition rate (fluctuation) characterizes those interviewed companies which were established earlier. By now, the sector faces shortage of properly trained employees. In one of the interviewed companies, there are 200 vacancies out of the 2,000 positions.

\subsubsection{Linkages}

Linkages and other local contacts between foreign investors and local firms can be one of those channels through which these projects may impact upon the local economy and local firms (see chapter I). In the literature, linkages between services projects and local economic actors are hardly analyzed. However, the literature on linkages in manufacturing can give some insights into those in services. There is a set of factors which influence the intensity of local linkages of a company with foreign participation (Sass and Szanyi, 2009). Chapter I of the book suggests that the following are particularly significant: the mode of FDI entry (greenfield or acquisition), the share of foreign ownership (I00\% foreign-owned and joint venture), sectoral differences, export-oriented versus domestic-market oriented investors (or vertical versus horizontal FDI), the gap between the performance of the 'foreign' and 'domestic' sectors (the larger the difference, the less the linkage), the age of the investment (for older investment there are more linkages), the quality and quantity of local suppliers, the size of the affiliate, the nationality 
of the investor, the global strategies of MNCs and the role of the affiliate in the production network of the company. The impact of these factors is especially relevant when the vertical, export-oriented nature of this type of project is taken into account and the role and independence of the affiliate in decision making is analyzed.

On the basis of our company interviews, in terms of backward linkages, they are quite limited for all companies functioning in the service sector. This finding is in line with that of Caves, who noted that for labor intensive processes there is less potential for backward linkages (Caves, 2007, p. 224). While the business service activities analyzed here are not unskilled but skilled-labor intensive, on the basis of the information gained from the interviews backward linkages are very limited in our sector as well. Local sourcing is confined to buying various 'basic' services from local companies, such as cleaning, security services, catering, and certain training services, and to using local infrastructure (telecommunications, electricity, financial services, other infrastructure), as revealed in the company interviews. There are only a few cases (two of the eight companies) in which part of the core activity of these companies is outsourced to local companies: one reason can be the temporary lack of capacities, another reason, which may result in a more lasting relationship with a local company, is when lower value-added activities are outsourced to local companies. The alternative to that latter is to relocate these activities to lower wage neighboring countries, which is what happened in one of the interviewed companies.

As far as forward linkages are concerned, they can benefit the host economy by raising the quality of business services provided for local companies. However, selling services to local companies is also at a relatively low level in our sample. Export intensity in terms of the percentage of export sales to local sales is close to $100 \%$ in most of the cases. In the captive cases, this is understandable: all services are exported except for when the local affiliate is served, though the share of this latter is minimal in the Hungarian captive cases. One Hungarybased company has a relatively low export/sales ratio of $60 \%$. Here one reason for the relatively high share of local sales can be found in the long history of the firm in the Hungarian market, where it has been present since 1991. This resulted in concluding longer-term contracts with big local companies during the I99os, including privatized Hungarian companies and local affiliates of GE, Coca Cola, Thyssen-Krupp, ABN-AMRO, and Sony. For another independent service provider, sales on the domestic market are significant, mainly because one plant of the local affiliate was acquired with the aim of serving the local market.

Thus the contribution of backward and forward linkages to raising the level of the competitiveness of local companies is rather limited in these cases. 


\subsubsection{Technology spillovers}

Direct technology transfer is important in the analyzed sector, as all companies use the highest level technologies, and they also use high quality management and production organization, as it is obvious from the interviews. However, as far as the 'leakage' of these technologies into the local economy is concerned, the analysis of it is outside the scope of this study. However, on the basis of company interviews, channels for this (including linkages and other contacts with the local economy) were limited.

\subsubsection{Mobility of trained employees}

One of the most important channels of local spillovers in this sector is through trained workers. All interviewed companies provide training to recruited employees. Some concentrate on knowledge and abilities directly connected to the actual work of the employee; however, there are others, which offer a set of courses, including language and self-development courses. In that respect, affiliates in the sector seem to deviate from other affiliates, because trainings organized by foreign-owned affiliates are usually narrowly focused on the actual needs of the activity that the employee carries out (Dunning, 1993, p. 372). In our sample almost all companies offered training which had a wider focus, the reason for which can be found in the knowledge intensive nature of the sector. Training has been continuous in all interviewed companies.

Some of these trained employees may either go to work at local companies, or set up their own companies (or go to work at another local affiliate in the sector, due to the arising shortage of relevantly trained employees). These kinds of 'spin-off' companies are the most present in computer and related services. Specific mention was made of these types of 'spin-offs' in the case of two companies interviewed. This phenomenon was especially important for one company dealing with software engineering, where training is relatively lengthy (between one and two years), and there are cases when former employees of the company set up their own small enterprise and carry out similar activities, successfully setting foot on the local market. The other company is an independent service provider and sells relatively large volumes on the domestic market, representing a confluence of vertical and horizontal FDI. Some smaller consulting firms were established as 'spin-offs' from this latter company. For other interviewed shared-services centers, where employees have no access to knowledge about the overall service process, this type of 'spin-off' is basically nonexistent. There was only one company in the interviewed sample where employees could get an oversight of the whole, not IT-related service process. However, maybe due to the young age of that company there were no such 'spin-offs' yet. 
It is important to note that in the case of employees not setting up their own small business, but going to work at a domestic company, it is not only the special knowledge on technology, management, and the accumulated skills that are transferred to local companies, but a kind of business culture and working ethics as well. This channel may contribute to raising the productivity of local companies and improving the business environment. ${ }^{8}$ However, from the company interviews it is obvious that employees tend to move more between foreign-owned companies in the subsector and that there are only a few workers who go to work at domestic companies. However, even moving between service centers may represent a kind of upgrading: when after some training and gaining experience from service centers with lower requirements, workers move to another service center with higher recruitment requirements. This was also mentioned by one company as a problem which caused high attrition rates and a quick increase in real wages in the sector.

However, one has to note that the knowledge transfer and organizational technology transfer to the local economy is very limited on the basis of the Hungarian experience. That is one reason why in this sector there are only a few Hungarian-owned companies that would be able to provide the required quantity and quality of services and could become an important domestic or regional player. Another reason for that can be that the appearance of business services offshoring and outsourcing companies has increased the competition for skilled labor, which first, may have a crowding-out effect on Hungarian firms in the sector, and second, may have an adverse effect on other industries in the economy. Shortage of skilled labor is especially apparent for example in IT and engineering in Hungary.

\subsubsection{Impact on local infrastructure and services}

Both companies with foreign and domestic participation use infrastructure and other services. One of the important elements of locational advantages for these types of investments is the availability of relevant infrastructure, especially an internet connection (broadband). Companies in the export-oriented part of the business services sector, through their intensive demand for some elements of local infrastructure and other services, contributed to the increase in the quantity and quality of services offered. First of all, telecommunications infrastructure and services are affected. According to UNCTAD (2004), improvements in ICT-related infrastructure is one of the most important spillovers from business services investments. Among other services, according to the interviews, the following are used the most intensively: training, catering, security, office space, financial services, and employment/job agencies. These are called 'usual services' in Table 2.5. One 
Table 2.5 Characteristics of the interviewed companies from the point of view of impact on the host economy

\begin{tabular}{|c|c|c|c|c|c|c|c|}
\hline 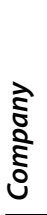 & 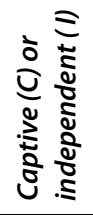 & 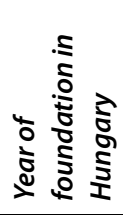 & 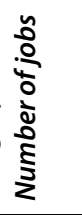 & 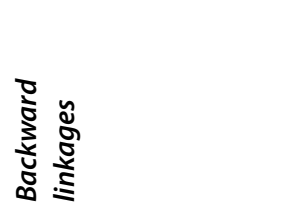 & 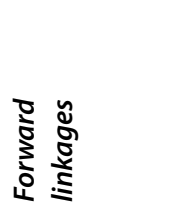 & 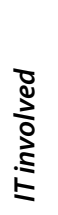 & 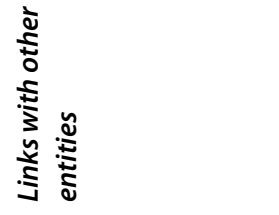 \\
\hline 1 & 1 & 1991 & 2000 & $\begin{array}{l}\text { Limited, but existent, } \\
\text { especially in software } \\
\text { development, with local } \\
\text { SME and cooperation } \\
\text { with SMEs set up by } \\
\text { former employees; } \\
\text { and the'usual' services } \\
\text { bought locally }\end{array}$ & $\begin{array}{l}\text { Significant, } \\
\text { about } 40 \% \\
\text { of sales to } \\
\text { the domestic } \\
\text { market }\end{array}$ & Yes & $\begin{array}{l}\text { Numerous: AMCHAM, } \\
\text { HOA, universities, } \\
\text { countryside local } \\
\text { governments and } \\
\text { labor centers }\end{array}$ \\
\hline 2 & $C$ & 2008 & 165 & $\begin{array}{l}\text { Negligible, the 'usual' } \\
\text { services bought locally } \\
\text { + furniture and office } \\
\text { supplies }\end{array}$ & $\begin{array}{l}\text { No }(100 \% \\
\text { export) }\end{array}$ & Yes & $\begin{array}{l}\text { AMCHAM, HOA, } \\
\text { universities }\end{array}$ \\
\hline 3 & $C$ & 2005 & 330 & $\begin{array}{l}\text { The 'usual' services } \\
\text { sourced locally }\end{array}$ & $\begin{array}{l}\text { Export/sales: } \\
\text { close to } 100 \% \\
\text { (one Hungarian } \\
\text { affiliate) }\end{array}$ & No & $\mathrm{HOA}$ \\
\hline 4 & $\begin{array}{l}\text { I (for- } \\
\text { merly } \\
\text { C) }\end{array}$ & $\begin{array}{l}2002(\mathrm{C}) \\
/ 2005(\mathrm{I})\end{array}$ & 600 & $\begin{array}{l}\text { The 'usual' services } \\
\text { sourced locally }\end{array}$ & $\begin{array}{l}\text { Export/sales: } \\
\text { close to } 100 \% \text {, } \\
\text { only one } \\
\text { Hungarian } \\
\text { client }\end{array}$ & No & $\begin{array}{l}\text { AMCHAM; through HR } \\
\text { for a: informal links, } \\
\text { business schools }\end{array}$ \\
\hline 5 & 1 & 2004 & 1300 & $\begin{array}{l}\text { Negligible, the 'usual' } \\
\text { services sourced locally }\end{array}$ & $\begin{array}{l}\text { Domestic sales } \\
\text { are significant }\end{array}$ & Yes & $\begin{array}{l}\text { AMCHAM, HOA, } \\
\text { universities }\end{array}$ \\
\hline 6 & $C$ & 2008 & 50 & $\begin{array}{l}\text { The'usual' services } \\
\text { bought locally }\end{array}$ & $\begin{array}{l}\text { Close to } 100 \% \\
\text { exports }\end{array}$ & No & $\begin{array}{l}\text { HOA, AMCHAM, } \\
\text { French Chamber of } \\
\text { Commerce }\end{array}$ \\
\hline 7 & 1 & 2005 & 750 & $\begin{array}{l}\text { The 'usual' services } \\
\text { bought locally }\end{array}$ & $\begin{array}{l}\text { Close to } 100 \% \\
\text { export/sales }\end{array}$ & Yes & $\begin{array}{l}\text { AMCHAM, HOA, } \\
\text { universities }\end{array}$ \\
\hline 8 & $C$ & 1996 & 250 & $\begin{array}{l}\text { The'usual' services } \\
\text { bought locally }\end{array}$ & $\begin{array}{l}100 \% \text { export/ } \\
\text { sales }\end{array}$ & Yes & $\begin{array}{l}\text { AMCHAM, HOA, } \\
\text { German Chamber } \\
\text { of Commerce, } \\
\text { Association of } \\
\text { Innovative Companies }\end{array}$ \\
\hline
\end{tabular}

Note: AMCHAM: American Chamber of Commerce; HOA: Hungarian Outsourcing Association. 'usual services': training, catering, security, office space, financial services, employment/job agencies.

Source: own compilation based on the company interviews 
manager explicitly noted that some local service providers were given technical and managerial help in finding relevant employees for the company. The increase in the quantity and quality of services, and the decrease in their prices due to the more intense competition may be beneficial for the domestic companies as well.

\subsubsection{Impact on the business environment}

All companies interviewed in the framework of the project were active participants in the local business life, with memberships and active participation in various local organizations (AMCHAM, Hungarian chamber of commerce, other chambers of commerce, and Hungarian Outsourcing Association). For the companies, these associations provide an informal forum for exchanging ideas, discussing experiences and so on. Moreover, through these associations, they can express their views about the business environment; exercise some pressure for changing certain detrimental elements of it. One company actively (and successfully) lobbied through AMCHAM for including certain jobs in the agreement with Romania and Bulgaria on the free flow of workers. Another reason is the unstable nature of the business environment due to frequent changes in taxes and in the regulatory environment, which makes the companies quite active in voicing their opinion. This type of association may bring benefits to domestic companies, because they provide a forum where domestic and foreign managers may meet and pass on information and knowledge to each other (see for example Dunning, 1993, p. 470). Trying to find traces of this was outside the scope of this study, but we can state that the membership of AMCHAM and the Hungarian Outsourcing Association consists predominantly of foreign-owned companies. Thus they can share information and knowledge only with a very few domestic-company members of these associations.

The interviews outlined that competition for relevant employees is one of the main factors determining local activities and links of the companies in the sector. This was to a great extent motivated by the fact that as more and more companies appeared in Hungary in this sector, the availability of relevant employees became more and more limited - and connected to that, wages started to move upwards relatively quickly. This problem motivates companies to build up local links with universities and other educational institutes. They approach students partly for temporary jobs, partly to offer them jobs after graduation. In Hungary, more substantial relationships in terms of research and development cooperation between the companies and universities were also established, and the companies also financed various university activities. The presence and problems of these companies called attention to the missing educational categories, and as a result of which secondary level training for future call center employees was introduced 
in seven secondary schools in Hungary. Moreover, the Hungarian Outsourcing Association, with the help of its members, recently organized a university level training course in service sciences, which will be taught in at least five universities in Hungary.

The analyzed companies use various measures to keep their employees. Besides relatively high wages, other types of benefits (for example free canteen, health care insurance) are given to employees, and social events and various trainings are organized for personal and skill improvements. Overall, the working environment in these companies can be evaluated as superior compared to an average company.

\subsubsection{Regional impact}

Agglomeration forces are at work when export-oriented services companies choose their locations (see for example locations in Table 2.6). Budapest hosts the overwhelming majority of these types of companies. However, the biggest one of the interviewed companies is now present in 20 cities in Hungary. There are only a few (smaller) centers or plants which move to the countryside. The main reason for leaving the city is the increasing shortage of suitable workers in Budapest, as was mentioned by the interviewed companies. In Hungary, especially three university towns (Miskolc, Szeged, Debrecen) close to the border gained some important projects. An additional advantage of being situated near the border is that people from Hungarian minorities in neighboring countries with 'small' languages can be employed. This factor played a part when for example one of the interviewed companies established a center in Miskolc. In the countryside, especially traditional university towns became hosts to these types of investments (besides the above mentioned cities, Győr and Pécs) and newly emerging local centers of tertiary education, such as Békéscsaba or Székesfehérvár. In the case of Székesfehérvár, a captive service center was established because a manufacturing affiliate of the same parent company was already present there. The low level of spreading out of these types of investments to the countryside is in line with the statement of UNCTAD (2004, p. 169), according to which the regional impact of that type of investment is very limited because of the relatively skilled intensive nature and the required high level of infrastructure.

\subsubsection{FDI policies concerning business services in Hungary}

The majority of the interviewed FDI projects is of the vertical type. For them incentives may play an important role when choosing among similar locations (usually among locations in the East-Central European region). According to 
the interviews, incentives are of secondary importance for companies, and their extent is quite limited compared to the invested amount or to the number of jobs created. However, in Hungary (and in other Visegrad countries, with the possible exception of Slovakia), attracting regional headquarters and shared service centers is one of the most important targets of investment agencies. Incentives offered for these types of projects are relatively generous in all three countries, though their generosity does not differ to a great extent from country to country. At present, most of the companies receive training-related grants or grants for job creation, financed from European Union funds. Moreover, projects deemed to have strategic importance can receive additional tailor-made support from the respective government. This exceptionally large support is offered to really big projects in the sector. However, EU-regulations limit the maximum amount/ share of offered incentives in all three countries, thus regional incentive competition is held back.

There is information on the overall financial support granted to these types of projects in Hungary up till the first half of 2008. The 16 companies (among them there are four which were interviewed) in Table 2.6 received HUF 9 billion (around EUR 35 million in 2008) financial support from the Hungarian state, which equals approximately HUF 700,000 (around EUR 2,750) support per job created (II,669 jobs). Other similar centers (their number can be between 25 and 35 and their average size smaller than of those in the table) did not receive any financial support, though many of them were helped by the Hungarian investment agency through providing information or mediating between the company and the local municipality of potential locations. Three of the eight companies interviewed received this type of other incentive of getting information and help from ITDH, the Hungarian investment agency.

In contrast to manufacturing, there is no special support for these companies to deepen their local contacts and to increase local supplies, which is understandable given the predominantly vertical and export-oriented (even export platform) nature of these projects. As another policy measure of special importance for the sector, after observing the growing scarcity of suitable workforce and lack of special knowledge, efforts were made in Hungary for introducing special secondary and tertiary level training courses for prospective employees. As was already mentioned, secondary level training for future call center employees was introduced in seven secondary schools, and a university level training course in service sciences, organized and managed by the Hungarian Outsourcing Association, will be taught in at least five universities. 
Table 2.6 Service centers that have received financial incentives in Hungary

\begin{tabular}{lllc}
\hline Company & Home country & Location in Hungary & $\begin{array}{l}\text { Number of jobs } \\
\text { (current or planned) }\end{array}$ \\
\hline ExxonMobil & USA & Budapest & 1200 \\
IBM ISSC & USA & Budapest & 1300 \\
Diageo & United Kingdom & Budapest & 600 \\
Getronics & Netherlands & Budapest & 510 \\
Jabil & USA & Szombathely & 719 \\
SAP & Germany & Budapest & 600 \\
Tata & India & Budapest & 450 \\
Convergys & USA & Budapest & 282 \\
EDS & USA & Budapest, Vasvár & 2000 \\
InBev & Belgium & Budapest & 380 \\
Budapest Bank & USA & Békéscsaba & 530 \\
Morgan Stanley & United Kingdom & Budapest & 450 \\
Citigroup & USA & Budapest & 302 \\
Vodafone & United Kingdom & Budapest & 746 \\
British Telecom & United Kingdom & Budapest, Debrecen & 700 \\
\hline T-Systems & Germany & Budapest, Debrecen & 1750 \\
\hline
\end{tabular}

Note: Getronics withdrew its application for the incentives.

Source: ITDH

\subsection{Conclusion}

Hungary, together with the Czech Republic, Poland and to a lesser extent with Romania, is increasingly involved in business and computer services outsourcing as a host country. More and more companies are present with their regional, European or even global centers there. Although Hungary's market share is still minimal it is growing inside the business and computer services of the European Union. The impact of these kinds of projects on the local economy hardly has been analyzed up till now. While this chapter could not look at all the aspects and channels of local impact and could not offer a quantitative analysis, it found that besides the medium- to high-skilled job creation impact, which is quite substantial, these companies have limited contacts with the local economy. Their forward and backward linkages are scarce, though forward linkages seem to grow with the age of the investment, if it can be characterized with a confluence of horizontal and vertical FDI. A more substantial form of local impact are spillovers through trained employees. While these employees prefer moving to other MNCs in the 
sector, there are some cases in which they move to domestically-owned companies or they set up their own small firms.

\section{Notes}

I Independent business services firms or outsourcing vendors are companies specialized in various business services (accounting, computer services, human resources, financial services and so on) selling their services to companies, which decide to outsource these activities.

2 Jensen et al. (2006) show the impeding role of the Danish language for offshoring certain service functions. Company interviews in Hungary also underlined the role of language barriers for offshoring and offshore outsourcing, especially for smaller European languages, though French and Spanish speakers are also not abundant in the East-Central European region.

3 Hollinshead (2008) also underlines the importance of nearshoring. Jensen et al. (2006) show that cost considerations are in many cases overwritten by the importance of nearshoring, thus for Danish companies Sweden, the United Kingdom and Germany are important offshoring partners. The preference for nearshoring explains partly the emergence of the East-Central European region in business process outsourcing.

4 Own approximation based on the data of the Central Statistical Office (employment) and the estimated number of jobs created.

5 A caveat is due because of the data and measurement problems, which is analyzed in more detail in Sass (2009). However, these data are presented here only as illustrations of developments in the sector.

$6 \mathrm{RCA}=$ revealed comparative advantage, showing relative specialization. It is calculated as the share of a good/service export in total goods/services export of a country compared to the share of the same good/services export in total export of another country or country group, in this case to EU-I5 and EU-Io countries.

7 Horizontal FDI is a demand-driven investment, where a company seeks to establish itself in new markets by supplying the same goods or services in a different country. Vertical FDI is a result of a firm's vertical disintegration, that is when the firm breaks the value added chain and carries out one part of its operation in another country/countries.

8 This is especially important in a country with a relatively big black and gray segment of the economy.

\section{List of references}

Barba Navaretti G. and A.J. Venables (2004) Multinational Firms in the World Economy, Princeton University Press, Princeton.

Bardhan A.D. and C.A. Kroll (2003) 'The New Wave of Outsourcing', Fisher Center Research Reports Paper IIo3, University of California, Berkeley.

Bajmócy Z. (2007) 'Tudás-intenzív üzleti szolgáltatások és a lisszaboni innovációs célkitüzés. (Knowledge intensive business services and the Lisbon 
innovation aims)', in B. Farkas (ed.) A lisszaboni folyamat és Magyarország, SZTE Gazdaságtudományi Kar Közleményei, I54-170, JATEPress, Szeged.

Blomström M. and A. Kokko (1997) 'How Foreign Investment Affects Host Countries', Policy Research Working Paper 1745, World Bank, Washington, DC.

Caves R.E. (2007) Multinational Enterprise and Economic Analysis, Third Edition, Cambridge University Press, Cambridge.

Chakrabarty S. (2006) 'Making Sense of the Sourcing and Shoring Maze: The Various Outsourcing \& Offshoring Alternatives', in H.S Kehal and V.P. Singh (eds.) Outsourcing and Offshoring in the 21st Century. A Socio Economic Perspective, 18-53, IGI Publishing, Herhsey.

Dicken P. (2003) Global Shift. Reshaping the Global Economic Map in the 2Ist Century, Fourth Edition, Sage Publications, London.

Dunning J.H. (1993) Multinational Enterprises and the Global Economy, Addison Wesley, Wokingham.

Dunning J.H. (1996) Foreign Direct Investment and Governments, Routledge, New York.

Egger H. and P. Egger (2003) 'Outsourcing and Skill-Specific Employment in a Small Economy: Austria and the Fall of the Iron Curtain', Oxford Economic Papers 55, 625-643.

Egger H. and P. Egger (2005) Labour Market Effects of Outsourcing under Industrial Interdependence, International Review of Economics and Finance I4(3), 349-363.

Francois J. and B. Hoekman (2009) 'Services Trade and Policy', Department of Economics Working Paper 0903, March 2009, Johannes Kepler University of Linz.

Gál Z. (2007)'Future Bangalores? Role of Offshoring in the Financial Centre Formation in the Major Central Eastern European Cities', in L. Weidong (ed.) Second Global Conference on Economic Geography, Beijing. Abstract Book, Chinese Academy of Science Department of Geography,Beijing. http://courses.nus. edu.sg/course/geoywc/conference/2007\%20EconGeog\%20Folder/2007\%20 SGCEG\%2oBook_small.pdf.

Gál Z. (2009) Future Bangalores? The increasing role of Central and Eastern Europe in services offshoring, Mimeo, Centre for Regional Studies of the Hungarian Academy, Pecs.

Geishecker I. (2002) 'Outsourcing and the Demand for Low skilled Labour in German Manufacturing.' New Evidence, German Institute for Economic Research Discussion Paper 313, November, Berlin.

Geishecker I. (2005) Does Outsourcing to Central and Eastern Europe really threaten manual workers' jobs in Germany?, Mimeo, Free University Berlin, Berlin.

Geishecker I., H. Görg and J.R. Munch (2007) ‘Do Labour Market Institutions Matter? Micro-level Wage Effects of International Outsourcing in three Euro- 
pean Countries', EPRU Working Paper Series March 2007, http://econpapers. repec.org/paper/kudepruwp/07-03.htm.

Ghibutiu A. and I. Dumitriu (2008) 'The Effects of Offshoring on Trade in Services. Evidence from Romania', ETSG Working Paper. http://www.etsg.org/ etsg_web/etsg_site/papers_detail.php?id=9I.

Gianelle C. and G. Tattara (2007) 'Producing abroad while making profits at home: Veneto footwear and clothing industry', Working Papers 35/WP/2007, Department of Economics, Ca' Foscari University of Venice, Venice. http:// www.dse.unive.it/fileadmin/templates/dse/wp/Note_di_lavoro_2007/ WP_DSE_giannelle_tattara_35_07.pdf.

Van Gorp D., P.K. Jagersma and M. Ike'e (2006) 'Offshoring in the service sector. A European perspective', NRG Working Paper Series June 2006, Nyenrode Business Universiteit, Nyenrode Research Group, Breukelen.

Grover A. (2007) 'International Outsourcing and the Supply Side Productivity Determinants', CESifo Working Paper 2088. http $: / / \mathrm{ssrn}$. com/abstract $=1015725$. Hamar J. (2005) 'Üzleti szolgáltatások Magyarországon' (Business services in Hungary), Közgazdasági Szemle, LII., November, 881-910.

Hansen M.W., H. Schaumburg-Müller and E. Potter (2007) 'Outsourcing for development', CBDS Working Paper Series 4, October, CBS, Copenhagen.

Hollinshead G. (2008) 'Offshoring in the financial sector', Presentation at the project meeting Foreign Direct Investment in Central and Eastern Europe: What Kind of Competitiveness for the Visegrad Four?, Hatfield, 8-io February.

Hunya G. and M. Sass (2005) 'Coming and Going: Gains and Losses from Relocations Effecting Hungary', WIIW Research Reports 323, WIIW, Vienna.

Jensen P.D.O., J.F. Kirkegaard and N.S. Laugesen (2006) 'Offshoring in Europe - Evidence of a Two-Way Street from Denmark', Institute for International Economics Working Paper Series 06-3, Washington, DC.

Kirkegaard J.F. (2005) 'Outsourcing and Offshoring: Pushing the European Model Over the Hill, Rather Than Off the Cliff!', Institute for International Studies Working Paper 05-I, Washington.

Lall S. (2000) 'FDI and Development: Policy and Research Issues in the Emerging Context', QEH Working Paper Series 43, 2-27.

Lindner A., B. Cave, L. Deloumeaux and J. Magdeleine (200I) 'Trade in Goods and Services: Statistical Trends and Measurement Challenges', OECD Statistics Brief $\mathrm{I}$.

Mankiw G.N. and Ph. Swagel (2005) 'The Politics and Economics of Offshore Outsourcing'. http://www.carnegie-rochester.rochester.edu/Nov05-pdfs/ Mankiwpaper.pdf.

Marin D. (2004)'A Nation of Poets and Thinkers - Less so with Eastern Enlargement? Austria and Germany', CEPR Discussion Papers 4358, CEPR, London. 
Metters R. and R. Verma (2007) 'History of offshoring knowledge services', Journal of Operations Management 26, 4I-I47.

Netland T.H. and E. Alfnes (2007) 'Internationalisation of professional services - A 1999-2005 literature review', College of Service Operations 2007 Conference, I2-I3 July.

Sass M. (2008a) 'Szolgáltatások relokációja - európai folyamatok’. (Relocation of services - European developments), Európai Tükör 7-8, 85-IOI.

Sass M. (2008b) 'Case Studies - Hungary'. Presentation at the project meeting 'Foreign Direct Investment in Central and Eastern Europe: What Kind of Competitiveness for the Visegrad Four?', Hatfield 8-io February.

Sass M. (2009) The New Role of East Central European Countries in the International Division of Labour in Services: Methodological Problems, Mimeo, Hungarian Academy of Science, Budapest.

Sass M., M. Szanyi, P. Csizmadia, M. Illésy, I. Iwasaki and Cs. Makó (2009) 'Clusters and the Development of Supplier Networks for Transnational Companies', Working Papers of the Institute for World Economics of the Hungarian Academy of Sciences i87, March, IWE HAS Budapest. http://www.vki.hu/ workingpapers/wp-I87.pdf.

Schöller D. (2007) 'Service Offshoring and the Demand for Less-Skilled Labour: Evidence from Germany', Hohenheimer Diskussionsbeitrage 287/2007, Universität Hohenheim, Hohenheim.

Sturgeon T.J., F. Levy, C. Brown, J.B. Jensen and D. Weil (2006) 'Why Can't We Measure the Economic Effects of Services Offshoring: The Data Gaps and How to Fill Them', Services Offshoring Working Group Final Report, Industrial Performance Center, Massachusetts Institute of Technology, Cambridge. www.mit.edu/ipc/publications/papers.html.

UNCTAD (2004) World Investment Report. The Shift Towards Services, UNCTAD, Geneva. 



\title{
3 Do multinational companies transfer technology \\ to local small and medium-sized enterprises?
}

\author{
The case of the Tegal metalworking industry cluster in \\ Indonesia
}

\section{Tulus Tambunan}

\section{3+1 Introduction}

It is often argued that the key to increasing the competitiveness and productivity of small and medium-sized enterprises (SMEs) in developing countries is to build the capacities of these enterprises through improved technology. This technology development can take place internally (inside the firm) or can be fostered through access to outside sources, including transfer of technology from multinational companies (MNCs). Technology here is defined broadly including the product, process, as well as management skills. ${ }^{1}$

There is a large body of literature on technology transfer, particularly from MNCs to firms in developing countries. ${ }^{2}$ However, very little work, especially empirical studies, has been done on technology transfer to SMEs in developing countries. ${ }^{3}$ Thus, with Indonesia as the case study, the main objective of this chapter is to fill this gap. It addresses the following two research questions. First, what role do MNCs play in technology transfer to SMEs in Indonesia? Second, under what conditions do MNCs play such a role?

Methodologically, this study is based on a review of key literature on technology transfer to Indonesia, and for its empirical part, a case study on the Tegal metalworking industry in Central Java was undertaken. For this case study, in-depth and semi-structured interviews and focus group discussions were conducted in Tegal district.

The structure of this study is as follows. Section II discusses the importance of MNCs as a source of technology transfer in Indonesia. Section III presents and discusses findings from the Tegal metalworking industry. Section IV gives concluding remarks. 


\subsection{Multinational companies in Indonesia}

There is a large body of literature on channels through which technology is transferred internationally. The channels include: MNCs' foreign direct investment (FDI); technical licensing agreements between foreign and local firms; imports of intermediate and capital goods; education and training in technologically advanced countries; turnkey plants and project contracts; technical consulting by foreign companies/consulting firms; and simply through participation in world trade (export) ${ }^{4}$

From the developing countries perspective, given that MNCs opt to produce in these economies, they are the preferred route and are therefore a prominent channel of technology transfer. For Indonesia too, MNCs are a more attractive means of developing technology in their industries than is obtaining technical licenses or other sources. The reason for this preference for MNCs over other sources of technology transfer is that with the latter, technology is provided, whereas with the former, it involves continuous interaction between the acquirer and the supplier of technology, and such continuous interaction is important for effective technology transfer since tacit knowledge is a component of virtually all technologies, and at the same time it is a long-term and difficult process. Therefore, for firms in developing countries, transfer of technologies through cooperation with MNCs is not only easier but also a better learning process than through, for example, imported capital goods. ${ }^{5}$

Probably, the importance of MNCs' FDI as a source of technology transfer in developing countries can be best shown by South Korea and Taiwan's success in developing their technology. In their early phase of development, they fully acquired technologies from abroad, though not only through MNCs (Evans, 1998). But now, with their successful ability to master and assimilate foreign technology, they are not only the most advanced economies among the developing world, but also major world suppliers of high-technology goods. ${ }^{6}$

During the Suharto era (1967-1998), the government tried to encourage the development of subcontracting linkages between SMEs and large enterprises (LEs), including domestic located MNCs by imposing a system of protection and local content rules in several industries including machinery, electronics and the automotive industry, as part of import substitution policies. The main aim of this local content policy was to encourage industrialization in the country and also to encourage a pattern of industrial development that followed the industrial pyramid model from Japan. In this model, small enterprises (SEs) were at the base to support medium enterprises (MEs), which then supported LEs at the top of the pyramid (TAF, 2000).

Industrial development supported by this local content policy in Indonesia, however, unexpectedly did not develop as strong production subcontracting link- 
ages between LEs-MEs-SEs as in Japan. On the contrary, the policy resulted in a vertically integrated production system within LEs. The Asia Foundation (TAF, 2000) argues that the lack of success of this policy in creating strong interdependence between SEs, MEs and LEs was largely due to the government's excessive interference, aimed at replacing the market mechanisms. ${ }^{7}$ Similarly, Thee (1990a; I99ob; 1997) argues that such production linkages did not develop smoothly during the New Order era because of market distortions and the lack of skills and low technological capabilities of local SMEs. SRI International (1992) found that such linkages between LEs and SMEs are weak and only a small number of clusters (all located in Java) established subcontracting relationships with LEs, including MNCs, mainly from Japan.

Although generally the policy was not very successful in developing viable domestic supplier firms, successful private-led subcontracting networks did arise in some industries, with the evidence showing that these arrangements did successfully facilitate technological capacity building. One example is the case of PT Astra International, part of the Astra international business group, Indonesia's largest integrated automotive company. Up until today, through a subcontracting system, PT Astra International has been able to develop many SMEs into efficient and viable suppliers. As a result of the rigorous training, which the company has provided to local suppliers with potential, over time, these suppliers are able to produce a wide range of parts and components for cars and motorcycles according to the strict quality standards set by Astra, and also to meet its strict delivery schedules (Tambunan, 2008).

The literature assessing the role of MNCs in technology transfer to local firms in Indonesia is still rather limited. Among the existing studies is Hayashi's (2002) study of subcontracting activities between SMEs and Japanese firms in four industries, namely, diesel engines, pump units for oil, bicycles and motorcycles in Indonesia. The study reveals that the subcontractors obtained technical support in various forms, ranging from quality control (QC) support, technical support during the production process, inspection via the dispatch of experts, the selection of proper production equipment, a study tour to foreign markets, assistance in designing, to various technical trainings.

Earlier, Thee and Pangestu (1994) tried to find evidence of technology transfer at the micro level in the Indonesian textile, garment and electronics industries. They found that in efforts to increase technological capability, Indonesian textile and garment manufacturers established strategic alliances with their Japanese counterparts, and that these alliances had become the most important channel of technology transfer. Similarly, they found that business linkages with foreign companies had been a very important channel for the transfer of technology within the electronics industry, especially for consumer electronics and electronic 
components. However, technology transfer in the textile industry was limited to improvements in production capability. Whilst important, more sophisticated activities that might help local firms upgrade their technological capabilities, including activities related to preinvestment, project implementation and technical changes in production or product were conducted by Japanese counterparts.

Others such as Sjöholm (1999a; 1999b) and Blomström and Sjöholm (1999) used cross-sectional data to assess technology transfer or spillovers from MNCs in Indonesia. They showed both the level and growth of labor productivity to be higher for locally-owned plants in subsectors with a high foreign share of output. This suggests that MNCs do play an important role in transfer of technology as the companies generate positive technology spillovers in Indonesian firms.

Overall, however, research is still inconclusive in relation to the importance of MNCs as a source of technology transfer to local firms in Indonesia, since there is little evidence of their significant contributions to technological capability accumulation through transfer of technology in domestic firms, especially SMEs. The possible reasons are the following. First, the mineral extractions in the country attracted more MNCs than in other sectors, but they are highly concentrated geographically and have high import content. Most of those operations are wholly owned by foreigners rather than joint ventures with local firms. They tend to operate as enclaves, such as the case of PT Free Port, an American gold mining company in Papua, or the case of Caltex in the oil sector in Riau, Sumatra, since they are weakly integrated into the country's domestic economy, as they have few forward and backward linkages with domestic firms. With this type of operation, important technology transfer channels from MNCs to domestic firms are largely absent. In contrast, MNCs in the manufacturing industry, potentially, will have greater technology transfer effects, since the industry is not geographically concentrated, and relatively more labor intensive, and it is easier for foreign firms to establish subcontracting links with domestic firms than in the mineral extraction. Second, although the Indonesian government has been very active in encouraging production links between MNCs and domestic firms, there are still many (although unintended) distortions generated by macro-, meso-, and microeconomic policies that put more disincentives than incentives for MNC subsidiaries to do subcontracting arrangements or other forms of linkages with domestic firms.

Third, many studies ${ }^{8}$ conclude that the presence of MNCs is likely to have a positive impact on local firms through transfer of technology only when the local firms have enough absorptive capacity, that is when they have human resources with adequate skills and basic technical knowledge. Whereas, in Indonesia, appropriate policies and institutional changes, especially with respect to $R \& D$ and human capital accumulation, in order to take full advantage in the form of tech- 
nology upgrading in domestic firms of the increased MNCs in the country are still lacking.

With respect to this third reason, findings from existing studies on subcontracting activities in Indonesia such as Harianto (1993), Kitabata (1988), Sato (1998; 2000), Supratikno (2001; 2002), JICA (2000), Iman and Nagata (2002) and Pantjadarma (2004) suggest that subcontracting arrangements between SMEs and MNCs in Indonesia is still weak, mainly because SMEs cannot meet the required standard of quality due to their lack of technology and skills. Also, from his analysis on how much technology has been transferred by Japanese companies through the development of Indonesia's car manufacturing industry, Tarmidi (200I) concludes that the main constraints to technology transfer in the automotive component industry were, among others, lack of basic technological know-how and an insufficient number of skilled workers. Nevertheless, all those studies have one common conclusion, namely that through subcontracting arrangements MNCs can play an important role for capacity building, including in technology, in local firms.

\subsection{The case of Tegal metalworking industry ${ }^{9}$}

\subsubsection{Brief history and profile}

The district of Tegal (Kabupaten Tegal), hereinafter Tegal, is part of the provincial government of Central Java located near the north coast on Central Java and close to the border of West Java on key trucking and rail routes. Major industries in the district include processed food (tea and tofu), textiles (batik and embroidery) and furniture (bamboo and wood). Based on data from the Tegal Regional Office of Industry and Trade in 2007 , the district generates $22.09 \%$ of its annual income from the industrial sector, compared to 24.24 and $24.62 \%$ from its trade and agriculture sectors respectively. Those three sectors are the largest contributors to the district economy. The other important sectors are services, construction, mining and transportation.

Tegal is among one of the few areas in Indonesia with a long history of development in the metalworking industry. It has been a metalworking center since the mid-I80os when it was the locus of several sugar processing factories and related enterprises including locomotive repair shops and metal-processing factories. The industry continued, thriving particularly under the New Order's massive infrastructure and development agenda. In the beginning of the 1980 s, the first subcontracting activity started in the district, sparking government activity to develop the metalworking industry. In the beginning of the I980s, as many MNCs, especially in the manufacturing industry, already entered the country, the first subcontracting 
activity started between local producers and a foreign affiliate company (Kubota), sparking government activity to develop the metalworking industry (Figure 3.I).

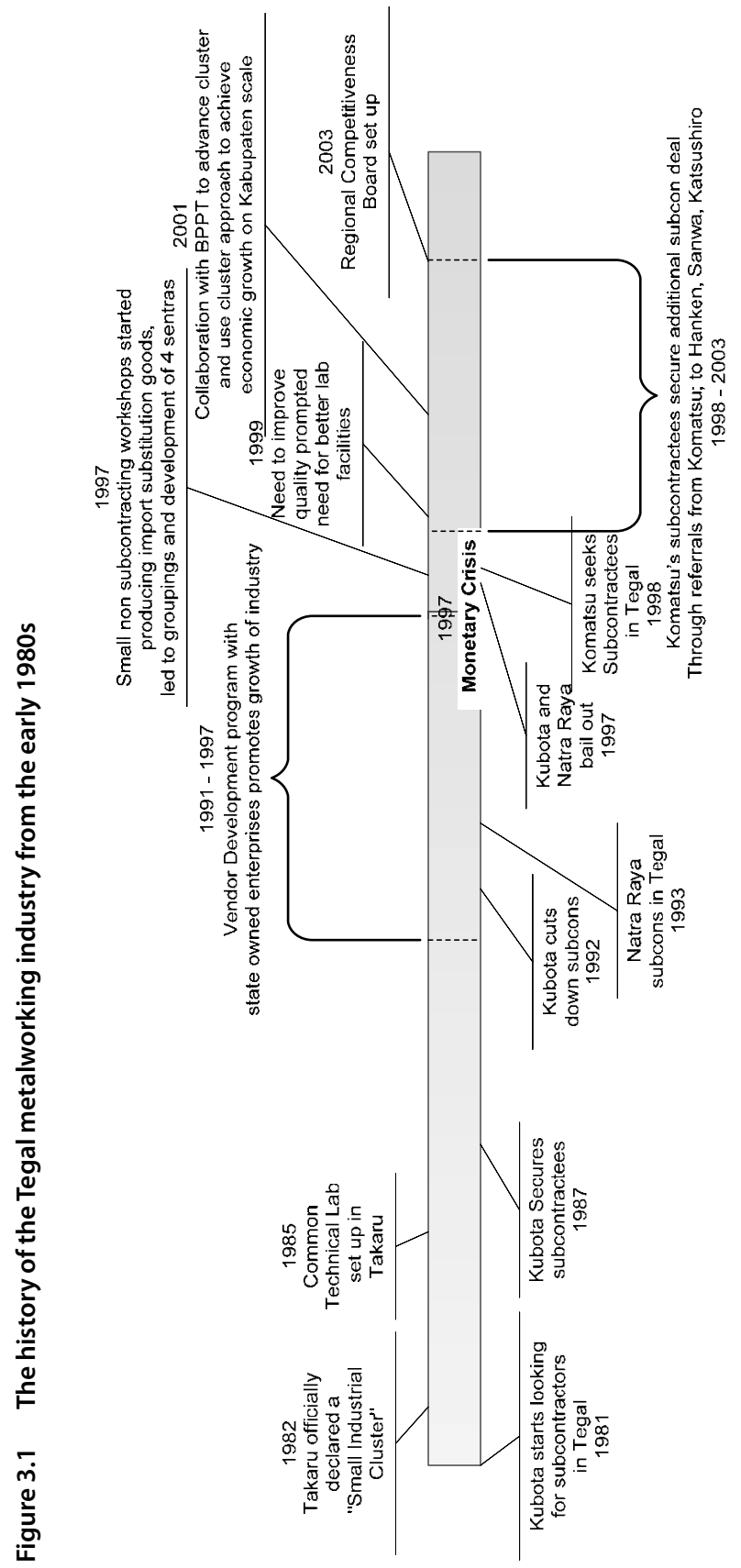


Most of Tegal's metal workshops rely on the same basic metalworking technologies, for example, casting, cutting, bending, drilling or stamping depending on the product, machining, welding, and finishing (painting or electronic plating depending on the product, and assembly). Most of the metal products are final consumer goods; metal craft, kitchenware, building fixtures, furniture, accessories and agricultural tools (sickle, shovel). Industrial goods range from various small items (nuts, bolts, washers, locks, hinges, door handles, some automotive components and ship parts) to hydrant pumps, hand tractor, coffee bean peeler and rice dryer. Their comparative advantage has been in filling small orders for simple metal products or components. The small size of workshops gives them greater flexibility and Tegal's abundant cheap labor can outweigh the productivity advantages of more capital-intensive production. There is often intense price competition between workshops.

During the execution of the survey in 2005 , the district had a population of I,423,346 people, and the Tegal metalworking industry employed about 30,029 workers out of 118,820 workers or approximately $25 \%$ of total workers employed in the district's industrial sector. There are around 2,81 metal workshops in the district, or about $10 \%$ of the total number of local enterprises in non-farm sectors. Among these are seven sentra or clusters, which are groups of geographic agglomerations of metal enterprises producing the same metal products, including LIK Takaru. Since the New Order era (1969-1998), clusters have become the focus of government development strategies for SMEs in all manufacturing subsectors, including the metalworking industry. The majority of metal workshops are small, employing less than 20 workers, mainly male.

Although metalworking involves a range of processes, the sector is dominated by the plate-forming business. Their comparative advantage has been in filling small orders for simple metal products or components, mostly for household appliances and handicrafts, but also for furniture, and, to a lesser extent, for parts and components for the general machinery and automotive industries. The small size of workshops gives them greater flexibility and Tegal's abundant cheap labor can outweigh the productivity advantages of more capital-intensive production. There is often intense price competition between workshops.

Pantjadarma (2004) made a general assessment of the level of sophistication of the production facility in the sentra which was based on a capability to utilize highprecision equipment such as computer numerical control (CNC) machines for production, degree of order and cleanliness of the plants. Although it is an imprecise technique, it provides some insights into the level of technological capabilities of the firms. It was observed that the majority of firms are not 'modern' enough. Also, that only a few had entered the export market. Nonetheless, Pantjadarma concludes that it has sufficient technological capabilities to serve the domestic market. 


\subsubsection{Main objective, methodology and sample}

The main objective of the survey was to answer these two questions: What role do MNCs play in technology transfer to SMEs in Indonesia, and, under what conditions may MNCs play such a role?

In relation to the objective, a multimethod approach was used for this case study, namely, interviews and focus group discussions. Since this study was exploratory, in which the author wanted to remain open to less tangible factors that could have an impact on technology transfer to and diffusions among SMEs, it was conducted according to the descriptive and hypothesis-generating approach (Yin, 1989) rather than the hypothesis-testing model. The respondents were not selected on the basis of pattern-matching, but on the basis of logistics and willingness of them to participate in the interviewing process. Since factors that may influence the three general features are possibly numerous, and the data that might help in hypothesizing regarding these factors are rare, not only semistructured but also in-depth interviews were adopted to as much evidence as possible in order not only to have a deeper understanding of the process of the three features and their determinant factors, but also to increase the validity of the study (Kirk and Miller, 1986).

The research focused on clustered metal workshops in the automotive and shipbuilding subsectors.$^{10}$ The sample consisted of 34 respondents including owners of inti (first tier supplier) and plasma (second tier supplier) who have subcontracting businesses, local workshop owners who supply only to retail markets, local government officials, and non-government organizations (NGOs). These respondents were selected from four subdistrics: Adiwerna, Talang, Desa Kebasen and Desa Dampyak. Some of them were interviewed semi-structurally, including relevant local government officials to discuss government-led technology diffusion initiatives and the history of subcontracting linkages in the district, while others were interviewed in-depth, including representatives of some subcontractors. The research focused on metal workshops in LIK Takaru. In addition, two focus group discussions (FGDs) were held in Desa Kebasen, including with ten local workshop owners to discuss the needs of their businesses and to rank and discuss governmental and private sector training that they received in the last five years.

\subsection{Findings}

\section{TYPES OF WORKSHOPS}

The structure of the Tegal metalwork value chain is illustrated in Figure 3.2. According to the size of production and level of production sophistication, there 
are two types of workshops in the Tegal metalworking industry: MEs and LEs as the modern type and SE as the traditional type of workshop. In addition, there are two types of subcontractors: workshops that receive orders for metal components directly from contractors, mainly LEs including MNCs outside the district, called inti, and workshops that make subcontracting arrangements not directly with LEs/MNCs but with the inti workshops, called plasma. The first type of subcontractors consists mainly of MEs and some LEs and plasma workshops are dominated by SEs.

Figure 3.2 Structure of the Tegal metalwork value chain

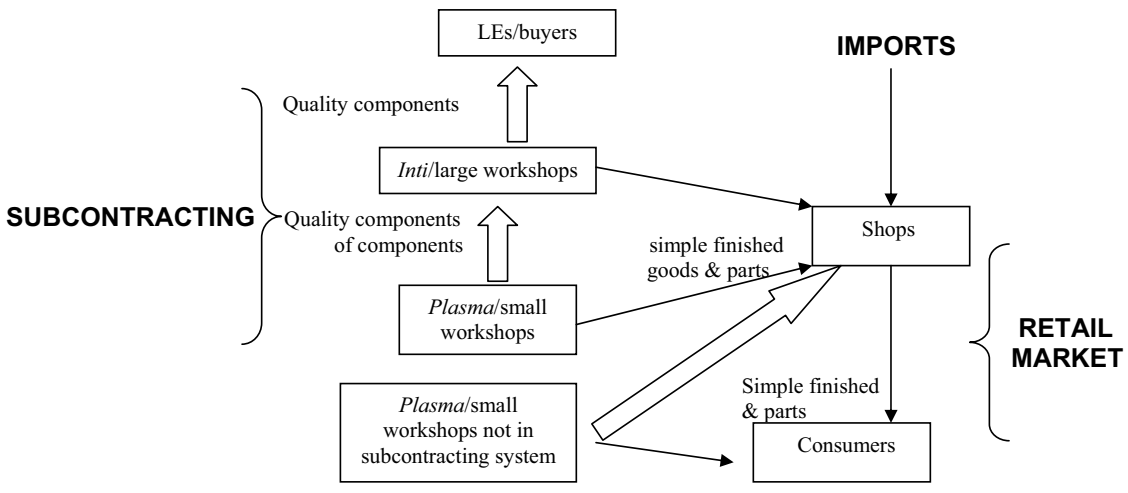

Especially large inti workshops with a total of employees up to Ioo men derive a majority of their income from subcontracting works. Inti workshops often subcontract part of their production to plasma workshops. Plasma workshops usually hire cheap, unskilled labor or use family members (mainly men) as unpaid workers (helpers) and the owner passes basic metalworking skills on to his employees, leaving the technical capacity of the workshop highly dependent on the technical capacity of the owner.

During the survey, there were several Japanese affiliated companies which subcontracted work to Tegal metal workshops, including PT Komatsu Indonesia Tbk, PT Daihatsu and some divisions of the Astra Group such as PT Sanwa, PT Kubota, and PT Katshusiro. These big companies often source metal components from several parts of the country, mostly in West Java. Among these companies, the most prominent one is PT Komatsu Indonesia Tbk (KI), which has established subcontracting production linkages with Tegal metal workshops since 1998." This company produces various equipments for construction and mining activities under the global trademark of Komatsu, such as hydraulic ex- 
cavators, bulldozers, motor graders, frames and related components, steel cast products as well as off-highway dump tracks. This case study focuses only on KI and its local subcontractors.

Local workshops that have no subcontracting businesses with other firms manufacture entirely for the wholesalers and retailers or sell their products directly to local consumers. Many wholesalers and retailers purchased goods from Tegal metal workshops for resale in city stores.

\section{EXAMPLES OF THE PROCESS TO BECOME A LOCAL SUBCONTRACTOR}

KI has periodically opened competition for new subcontractors (inti). However, not all local producers/workshops could become subcontractors. Many candidates tried but failed to meet the requirements. Especially for SEs, which in general are poor in necessary resources such as capital and skilled workers compared to MEs, establishing subcontracting relations with MNCs is not an easy task. To become subcontractors, local firms must have attained a certain level of technical and managerial capacity. They must prove that they have the capacity to produce high-quality components and meet the stringent delivery times. An audit determines if they have the required machinery, manpower (they must have enough manpower to have two shifts for higher productivity), facilities, legal standing ${ }^{12}$ and use of ISO standards (KI as many other LEs require the use of ISO standards even if the workshop is not officially certified). Subsequently, they are requested to produce a sample component from provided technical drawings. According to KI's inti workshop owners interviewed, before an agreement is signed, KI often ask for a trial run of the mass production process, subjecting the output to quality control tests. If they could produce a certain product item on a regular schedule and consistent quality, they would then be granted a license for manufacturing different product items, thereby expanding their product lines. In the past few years, many suppliers have been tested through a few initial batch orders, but, in the end, only some of them were able to meet KI's satisfaction; two of them, that is PT Prima Karya and PT Karya Padu Yasa, were included in the sample. ${ }^{13}$

The owners of these firms have learned a lot about many things from KI, such as quality control, standardization, and efficiency and all these have increased their innovation capability. The success of these two firms indeed can be seen as a direct reflection of the importance of MNC as a source of technology transfer to local firms. PT Prima Karya specializes in making parts and components for heavy equipment and it was formally incorporated in 1983, beginning operations with the manufacture of spray cans and agricultural machinery such as hand trac- 
tors. Currently, the company has 50 employees, of which more than $50 \%$ are high school graduates or under and two are university graduates. The company's first experience as a subcontractor started in 1985, as it won a contract with a large local conglomerate for manufacturing large quantities of 'coffee peeler' machines (although the contract was later terminated due to the economic crisis in 19971998). Currently, besides being one of the inti suppliers for KI, the company also succeeded in becoming one of the prime local suppliers for Natra Raya (NR), an affiliate of US Caterpillar, which came to Tegal in search of potential suppliers. It has managed to expand its product lines to more than Ioo items supplied to $\mathrm{KI}$ and to NR on a regular basis. Total turnover in 1999 was Rp 650 million per year and increased continuously though slightly in recent years. The company virtually was a manufacturer of heavy equipment parts, including engine tools, dashboards, and forklift parts. It expanded its operations to include the manufacture of pumps, agricultural equipment, parts for scales and door railings for sale to the general market. These jobs were merely incidental orders received along with the routine work the company did for KI and NR. Prospects for growth are extremely favorable. However, the company is chronically short of working capital because of the arrangement whereby payments are made only after the final products are manufactured and delivered.

The company has a great innovative capability. The fact that the company was able to advance from making relatively simple products to supplying metal components with higher grades of precision on a consistent basis demonstrates its ability to learn and increase its skills. This ability is largely attributable to the owner who has been vigilant in solving on-site technical problems. According to the owner, being accepted as a prime KI supplier was his company's first milestone, a role which requires in advance the ability to translate technical drawings and to work toward the final product. Another prerequisite fulfilled by the company as a prime KI supplier was a level of quality that ensured that no rejects were classified as fatal ones; the company was able to correct defects easily and ship the products back to $\mathrm{KI}$.

The company reached the second milestone when it was presented with the challenge of supplying a large complex piece associated with engine hoods. Making the first sample proved to be quite difficult using the inappropriate machinery available at the time. Even with several days help by an expert from KI, the company was still unable to produce a satisfactory sample according to specifications. After several trials driven forward by the persistence of the owner, PT Prima Karya finally sent the finished sample to KI at the end of the week. Approval was achieved not long afterwards.

All jigs and fixtures that allow assemblage and welding on a consistent basis are built by the company itself. Much of the machinery is developed in house, 
such as large bending and pressing machines, with up to $70 \%$ local contents. This level of accomplishment demonstrates the experience and skills the company acquired, largely in tacit or unspoken form, as it overcame each major challenge. One of the benefits obtained by working with $\mathrm{KI}$ is the opportunity to send employees to be trained at KI's facility in Jakarta.

PT Karya Padu Yasa has also a similar success story. The company has three plants, each with a specific production objective, namely for: I) casting, principally hydrants and fire monitors; 2) incidental job orders, usually in small lots; and 3) a stamping process especially for large parts and automotive components. It began by making textile equipment and parts in Jakarta in the 1950s. After the company moved to Tegal, it diversified into making agricultural tools and machinery. While rapidly diversifying its product base, it improved its productive capability. Among the important achievements of the company was the development of the casting capability to produce hydrants. Hydrant manufacturing was driven by a government contract. At the peak of production, the company made around 200 units per month.

One major milestone for the company was to be selected as one of the few local prime suppliers for heavy equipment not only for KI but also for NR. Furthermore, because of its ability to deliver the products in timely fashion with consistent acceptable quality, PT Karya Padu Yasa's base of product lines in the heavy equipment business expanded rapidly. However, the company manufactures fewer items compared to PT Prima Karya for both KI and NR.

Recently, a sign of positive growth emerged as hydrant orders began to increase to IO-20 per month, with a similar increase in orders from KI and NR. However, because of the arrangement under which payments are sent only after the final products are manufactured and delivered, the company suffers from shortages of working capital, especially after the substantial layoff of workers.

The company has ample facilities for metalworking operations, which range from casting to welding to finishing. What is more impressive, however, is the company's ability to make an increasingly complex range of products as it acquires experience over time. As noted previously, this ability was a key factor in being chosen as one of the regular suppliers of KI and NR. The company's most recent accomplishment was its expansion into the manufacture of automobile components for an automaker. This move was soon followed by the construction of a plant dedicated to the stamping process. The company equipped the plant with its own dyes and fixtures, and also set up a small crane to make a large heavy bottom piece for a tractor. It manufactures many of the machines and tools it uses in this plant. Its dedication to efficiency is also demonstrated by its efforts to minimize waste from paint spraying by constructing six large fans directed at a pool of water to capture paint droplets. The stamping plant's overall facilities are well organized and maintained. 
Finally, the company devotes considerable attention to skill development. It provides incentives to employees to participate in various training activities at other locations by covering their travel and accommodation expenses.

During the survey it was learned that larger and more modern workshops are more likely than their small counterparts to adopt new technologies in their bid to become subcontracting inti to KI. By building upon existing technical and managerial capacity, they are thus able to enter a virtuous circle where quality output leads to subcontracts which lead to private training provided by KI. Most of those who have been accepted as subcontractors for KI had worked before as employees for many years in KI or other MNCs in the same industry. It was found that only some SEs have indirect subcontracting with KI through a plasma relationship with its inti subcontractors.

For those who failed to become subcontractors, lack of capital, limited skill, and no access to information appeared to be the three most important constraints. They did not have enough money to purchase the required machinery and to hire sufficient workers (generally, SEs are self-employment units without helpers or hired workers). They often use second-hand or homemade equipment. If they hire workers, they are often low-skilled workers with little or no experience who rely on the shop owner's technical knowledge. ${ }^{14}$ Since many SE owners built their expertise through working in small shops (and never worked in LEs/MNCs) and rarely have formal academic training, they have difficulties reading technical drawings and instead rely on copying samples, which leads to less accurate output. So, they lack the technical experiences to produce complicated components with the precision required by LEs. Also, due to lack of information and skills, they did not know how to meet ISO standards. They said during the interviews that from the government they could not expect too much. The government did give some information, but they needed direct assistance too, which they had never received, or if they did it was often irregular, both from central and local government.

\section{MAJOR TECHNOLOGY PROVIDERS}

In general, the technical capability of the Tegal metal industry has derived from a long history of family experience in metalworking or similar industries. Accumulated technical knowledge of over 20 years, since the first subcontracting activity started in the district, has sparked government activity to develop the metal working industry. They are now capable of producing various kinds of agricultural and industrial machinery, as well as automotive and ship components. However, the quality of most of their products is low. Only in a few firms whose core businesses cater to as the likes of KI does the need for consistent product quality become a concern. In such firms, the ability to translate technical draw- 
ings and to manufacture products according to listed or drawn specifications is actively developed (Iman and Nagata, 2002).

Tegal metal industry's main external technology providers are LEs, mostly foreign affiliate companies such as KI to their subcontractors (inti workshops). ${ }^{15}$ After winning a contract with KI, an inti subcontractor has access to a significant level of technical training. According to one subcontractor of KI, trainings directly addressed the technical needs of the workshop in meeting the production requirements of KI. Indonesian experts from the Jakarta Komatsu office leading the training used a teaching style that clearly delivered the necessary knowledge and emphasized practical application, with $90 \%$ of training time spent on handson practicea. Trainers also help the workshop identify problems and troubleshoot.

However, according to the owners of the two KI's inti workshops, the training does not seek to develop their capability to rise beyond their capacity as low-cost production centers for selected components. Moreover, KI does help them gain the capacity to manufacture component parts, but there has been little interest in upgrading from specialized parts manufacture to manufacture and assemblage of finished products.

For workshops which were rejected by KI as inti subcontractors, because they did not have the capacity to produce high-quality components (they did not have the required machinery, manpower, facilities), the only source of technology or knowledge is from wholesalers/retailers by informing workshop owners about consumer preferences, demand, production methods, appropriate technology to be used and new innovations. The workshops generally sell the wholesalers/retailers a limited range of simple final products, such as pulleys and ship windows. One workshop owner stated in the interview that the retailers created new products and commissioned them from the local small workshops. While for KI quality is the first priority, retailers generally emphasize low cost over quality. Some other interviewed workshop owners who sell their products only to retail markets said that strong competition among retailers inhibits knowledge transfer and, instead, encourages the production of low-quality, inexpensive products.

If they are lucky the workshops can become plasma for KI's existing inti subcontractors and thus they can gain from the incentive to produce higher quality for a higher price with technical coaching from inti clients in their own virtuous circle. Inti respondents for auto components, for instance, turn to plasma workshops to produce some parts of their orders from KI, usually components of components or basic parts made more cheaply in small workshops while still passing the quality control requirements of KI. Learning or technology transfer to plasma, not directly from KI but from KI's inti subcontractors, takes place through quality control as inti subcontractors build a procedure for troubleshooting mistakes 
into their subcontracting relationships with their plasma workshops. Often soft loans are provided by inti to plasma to help them acquire new machines capable of higher quality output. In some cases, inti workshops support their former employees already familiar with these standards in starting up plasma. ${ }^{16}$

For workshops that have no subcontracting arrangements with KI or with KI's inti subcontractors, the only source of technology is from government training programs and some technical assistance. In fact, both inti and plasma subcontractors also often use government sponsored facilities such as the UPT (a technical service unit, including laboratory), especially to test the quality of materials. They are able to offset lab usage costs through the higher price paid by LEs for quality parts.

\section{KNOWLEDGE DIFFUSIONS AMONG WORKSHOPS}

In is often stated in the literature that the presence of MNCs is likely to have a positive impact on local firms in the host countries through transfer of technology only when the local firms have enough absorptive capacity, that is, they must have human resources with adequate skills and basic technical knowledge. Without these factors, MNCs can crowd out domestic firms with a technological gap that is too wide to bridge. ${ }^{17}$ However, in addition to this necessary condition, in order to materialize the spillover of technology transfer from MNCs in the receiving country, there should be undistorted knowledge diffusions among local firms, which can be in various forms, such as through production linkages or cooperation in $R \& D$ among local firms. Without this, only local firms having direct linkages with MNCs, which are often limited in number, will gain benefits. The transferred technology would not go further from the first recipient firms to other local firms.

There are many factors which affect the extent and the speed of domestic diffusion of technology among firms, and it is generally believed that the clustering of firms is one of the factors. A cluster can be defined as a geographical concentration of firms, not only from the same industries (for example, car, motorcycle and machinery industries) but also those operating in related industries (for instance, industries producing automotive components or spare parts) or sectors (for instance, banks, raw materials suppliers and trading companies). In the literature on industrial clusters it is stated that through close cooperations among firms in a cluster, clustering can be a powerful means for diffusion of technology among firms. ${ }^{18}$

Existing literature on SME clusters in Indonesia shows, however, little evidence of strong internal networks among firms inside the clusters. For instance, Sato (2000) found no interfirm specialization of work processes and no joint actions in technological development of in other aspects such as production, mar- 
keting and distribution among the firms inside the cluster studied. Supratikno (2001; 2002) also saw limited interfirm specialization and cooperation among producers inside the clusters. He concludes that the importance of a cluster for technology development as well as for production and marketing depends on whether there are leading/pioneering firms inside the cluster. These are usually larger and faster growing firms that are able to manage a large and differentiated set of relationships with firms and institutions both within and outside clusters. Such firms usually have utilized cutting-edge technologies in production.

In the Tegal case, it was found that interfirm linkages exist to a certain extent. Notably, producers in the cluster have a long tradition of collaboration in production as well as marketing and the procurement of raw materials. It is also indicated by the important role initiated by Takaru cooperative, a cooperative of producers in the cluster; though not all producers in the cluster are members of the cooperative. This cooperative was especially established to stimulate strategic alliance among them. This activity has a strong flavor of business and technology which is based on market requirements and it has produced a hand tractor with own design for the domestic market. As quoted from Pantjadarma (2004): the manufacturing of the customized hand tractor is considered as a bonding agent for this collaboration' ( $\mathrm{p}, 20)$. The production of this hand tractor involves I7 firms producing different parts. The Takaru cooperative organizes, assembles and performs quality control checks. The latter requires a certification process and this has to be conducted by other institutions including a government research laboratory (Pantjadarma, 2004). Many of these producers involved had done subcontracting activities with foreign firms before. No doubt, as they said themselves, that their knowledge obtained from working with these foreign firms made them able to produce this hand tractor.

However, from the interviews, it appears that in general knowledge transfer among workshops in this Tegal cluster is often contingent on personal networks and conditioned by competition. Especially among workshops producing for the retail market, competition sometimes becomes 'unhealthy', which has the opposite effect of inhibiting knowledge diffusion among them. For example, when a competing firm bought a shop owner's driver after a marketing trip and sold it on with lower bids to the same potential clients. Many workshop owners were worried about the tactics of firms to reduce production costs, often at the expense of quality. Some workshops found the right combination of cheap scrap metals to get their products to pass buyers' inspection standards, but these lower quality items wear out more quickly and do little to strengthen the reputation of the Tegal metalworking industry as a whole. This cost-cutting in turn creates price pressure forcing competing workshops to a race for the bottom in terms of quality. 
Some workshop owners stated that there was hesitancy among metalworkers to share new and possibly advantageous technical knowledge, especially from producers who are working as inti or plasma subcontractors to MNCs to other producers outside their group. The same hesitancy was seen in giving too much training to employees. Ex-employees were likely to start up competing businesses, as was the case with one interviewed workshop owner who lost $40 \%$ of his retail market share to ex-employees who began producing ship windows out of lower grade materials.

Marketing information is kept even more closely guarded. In addition to the tactics mentioned above, sometimes domestic market suppliers will come to the sentra and play the workshops off against each other, using their proximity and lack of specialization to engage them in competitive price cutting. The interviewed owner of PT Karya Padu Yasa, one of the district's most successful metal workshops in both subcontracting and retail production, explained that lack of trust and mutual suspicion between metalworkers was the main constraint to the development of metalworks and was the reason for the lack of growth in metalworkers' associations.

\section{THE ROLE OF THE GOVERNMENT}

Tegal district government has demonstrated a high level of awareness of the importance of enhanced knowledge and skills to improve the competitiveness of local metalworking shops. It has attempted to both facilitate direct training as well as build up supporting institutions that can assist firms, and lower information costs among firms. The district government has currently partnered with outside institutions, including strong partnerships with the Central Government's Indonesian Agency for the Assessment and Application of Technology (BPPT) and with an NGO, Yayasan Dana Bakti Astra (YDBA). Since 200I, the majority of training provided by the district government has focused on technical subjects or technical quality management processes. Especially for plasma without direct subcontracting links with LEs and retail market workshops, local governmentfacilitated technical training remains the only source of technical information outside the past experience of the workshop owners. But, many inti owners who receive only limited management training from LEs also participated in government training. Maybe it can be said that a concrete example of the role of local government is the case of the production of the hand tractor organized by the Takaru cooperative, as explained before, which enjoyed strong support from local government officials (Pantjadarma, 2004).

However, from the interviews and focus group discussions, it appears that training provided by KI has proven to be the most successful method of efficient- 
ly transferring knowledge to its inti workshops. While government-led initiatives attempt to cover a broader range of workshops, this did not result in the efficient transfer of high-quality, usable knowledge to inti workshops. According to respondents who participated in government training, these activities were poorly targeted, often exceeding their skills or not suitable for the available machinery or conversely focusing on skills they had already mastered. Those who did obtain training initiated by LEs state that private training materials are very suitable for improving their business. It is revealed from focus group discussions and interviews with local government representatives and some local NGO, that lack of sufficient funds, a small number of skilled staff dedicated to the effort, and weak feedback mechanisms between government and metalworking shops are other important factors that made these government trainings not very successful at systemically improving the skills of local firms.

In 1997, the district government opened a new laboratory and a polytechnic as part of the technical service unit (UPT) inside the cluster to enhance the ability of the subcontracting workshops to produce with precision. The first governmentfunded UPT lab opened in 1982. There the metalworking cluster was able to access the machines necessary to fill their orders. But, many respondents complain that the UPT was not able to keep up with technical advances. All the four KI's inti workshops rarely use the UPT facilities. They said that the facilities are aging and that there are many associated business management problems. They especially needed technical support for heat treatment and moulds, but the UPT could not provide that, so they do the work by themselves with the help from KI. In other words, KI provides better technical services to them than the UPT does.

This evidence of the relatively weak performance of UPT in the Tegal cluster is supported by evidence from many other studies. For instance, from his observations on the importance of UPT in many SME clusters in Indonesia, Dierman (2004) notes that: I) types of services are highly supply-oriented rather than demanddriven; 2) most of the machines and equipment are outdated. Originally, UPT in SME clusters were supplied with modern technological machines and equipment. However, over the years, especially after the economic crisis in 19971998, budget constraints have prevented the replacement of the existing equipment; 3) services have been delivered indiscriminately to clusters; 4) the staff of the UPT had not had the appropriate training to respond to entrepreneurs' needs; and 5) there was not great enough flexibility in the system to respond to the changing needs of SMEs, possibly due to the bureaucratic structure of the UPT.

By the end of the I990s, a number of initiatives were implemented in the cluster, including the launch of an initial campaign to introduce information and communication technology as an enabling tool to accelerate the technological upgrading process. The campaign was supported by the Information Unit for Small 
Businesses and Cooperatives (UIUKK) located within the Regional Office of Department of Trade and Industry vicinity led by a highly dedicated government official. This was led by the Takaru Cooperatives with assistance from a mechanical engineer with strong ICT capabilities. At the moment, there is one Internet Service Provider in Tegal (wasantara.net) offering a discounted subscription price for the Tegal SME community (Pantjadarma, 2004).

\subsection{Concluding remarks}

There is a huge amount of literature on technology transfer and the role of MNCs in it. However, the literature mainly focuses on LEs, or there is no explicit distinction between LEs and SMEs. In other words, knowledge on what role MNCs play in technology transfer to SMEs and under what conditions these MNCs play such a role, especially in developing countries, is rather limited. This Indonesian story, therefore, may contribute to close the gap in the literature.

This Indonesian story comes with microevidence from the Tegal case which shows that MNCs do play an important role as a source of technology transfer to SMEs in developing countries, through two main channels. First, via subcontracting arrangements: KI has functioned as the most important source of technology to, at least, its inti subcontractors and, indirectly, its plasma suppliers. No doubt this MNC has played an important role in improving technology and hence the production capabilities of PT Prima Karya and PT Karya Padu Yasa, as its main local suppliers. Second, via transfer of labor: local workshops accepted as subcontractors for KI had worked as employees in KI or other foreign affiliate companies before.

However, only a few workshops are able to become local subcontractors to KI, and small enterprises in particular are largely excluded from direct transfer of technology from KI, since this MNC (and other foreign companies in general) is more likely to subcontract parts of its production to local firms which already have a certain level of technology capability. This means that the presence of FDI in an industry in a developing country does not automatically lead to technology improvement in SMEs in that industry. It depends on the readiness of SMEs to absorb advanced technologies brought by FDI. In other words, the more technology absorptive capacity the local SME have, the more benefit they will gain from the presence of FDI-based companies.

Thus, the findings from the Tegal case may suggest that currently, within SMEs, MEs are abler to gain benefit from the presence of MNCs than their smaller counterparts, as MEs are abler to meet requirements to become subcontractors. If this evidence represents the current situation in developing 
countries that only a few SMEs are ready to become local suppliers for MNCs, then technology transfer from MNCs will be limited only to a small portion of SMEs in developing countries. Consequently, the presence of MNCs will result in an increased technology gap and hence development dualism within SMEs. Here then, the role of the government is crucial. Its SMEs development programs should focus on capacity-building in less technological advanced SMEs. Also, to have an optimal spillover effect, a strong cooperation between the few SMEs as the first technology recipients and the rest of SMEs should be in place and, here again, the role of the government is very important as the main facilitator.

\section{Notes}

I As generally realized, there is no universally accepted definition of technology. The most common approaches define technology as a collection of physical processes that transform inputs into outputs and the knowledge and skills that structure the activities involved in carrying out these transformations' (Kim, I997, p. 4), or as stated in Rosenberg and Frischtak (1985), that technology is a quantum of knowledge resulting from the accumulated experience in design, production and investment activities that is retained by individual teams of specialized personnel. This knowledge is mostly tacit and often (is) not made explicit in blueprints or manuals. So, technology and knowledge will be used interchangeably in this chapter.

2 See for example Islam (I992), Blomström and Sjöholm (1999), Nelson and Pack (I999), Saggi (2002), Morcos (2003), Thee Kian Wie (2005), UNCTAD (2007), Yusuf (2003, 2007), and Yusuf et al. (2003).

3 Most literature on technology transfer from MNCs to developing countries focus on large enterprises (LEs), or they do not make a distinction between SMEs and LEs. There are only very few studies on technology transfer to SMEs, which include Islam (I992) and Marcotte and Niosi (2005).

4 See for example, Kim (1997), Thee (2005), Yusuf (2003) and Saggi (2002) for a survey of literature.

5 See for example, Marcotte and Niosi (2005), Yusuf (2003) and Saggi (2002) for a survey of literature.

6 See for example, Kim (I995; I997), Nelson and Pack (I999), Yusuf (2003), and Hsueh (2006).

7 The economic rationale behind the local content policy was to create a captive market for domestic products in order to increase the economic scale of production and thereby to increase efficiency. However, government interference went too far. The government decided which products were to get priority in this policy and introduced fiscal incentives in line with the type of priority recipient products. The determination of priorities does not always appear to have been on economic considerations, such as SMEs' capacity for investment and absorption of technology.

8 See also among others, Saggi (2002), Rajan (2005), Palit (2006), and Palit and Nawani (2007). 
This case study was part of a research project on Rural Investment Climate Assessment (RICA) in Indonesia for the period 2005-2006, which was one output of World Bank's Indonesian Poverty Team (INDOPOV). The project was financed by the World BankNetherlands Trust Fund for Institutional Development and Capacity Building and the DFID Poverty Reduction Partnership Trust Fund. The Tegal survey was conducted by the author, as the main researcher, together with Stefan Nachuk, as the team leader, and Agni Paramita and Nunik Yunarti as two main surveyors. The findings of the survey were first published as a consultative draft by the World Bank in July 2006 (World Bank, 2006). These two subsectors were selected by the local government for intensive assistance based on existing competency in terms of access to 'key markets', quality management systems, and able and willing to cooperate with other workshops.

I I By the end of the I990s, KI occupied the first rank with a $40 \%$ share of sales and played an indispensable role in the localization of production. KI also fulfills a crucial role in Komatsu's international business strategy, as it serves as a construction machinery production base along with Komatsu's facilities in the USA, Brazil, Germany and the UK, and conducting global sourcing with other production bases (Iman and Nagata, 2002).

I 2 KI as many other LEs require their subcontractors to be a PT (Limited Liability Company) not a CV (a Limited Partnership not involving a legal person and personal assets are liable for obligations).

I3 The interviewed representatives of these two inti subcontractors said that their reputation and personal network was also a critical factor for their successful bid to become subcontractors. However, they have insisted that the opportunity to become KI subcontractors was open for every workshop in the cluster as long as they could prove themselves to be capable of meeting the quality requirements asked by KI. KI has periodically opened other competitions for new inti.

I Cheap labor and relatively small, shifting job orders reduces incentives for them to specialize or acquire expensive machinery to increase productivity. As one seasoned metalworker explained, the strength of the plasma workshop is the flexibility to do smaller orders. However, this flexibility becomes a liability to capacity development when workshops must fill many small orders and never develop specialization that leads to an expanded command of technology.

I5 Japanese companies are sometimes accused of being more centralized than firms from other countries and are therefore less inclined to share knowledge with local firms in the host countries. This was also the main reason, as officially stated, for the Indonesian government during the Suharto era to build the national car industry 'Timor' in cooperation with Kia Motor Company, South Korea. However, due to increasing production costs and competition pressures, Japanese MNCs have become more reliant on local suppliers, and, in order to have local components with their required quality standard, Japanese MNCs have become more open to knowledge-sharing with their local suppliers.

I6 The owner of PT Karya Padu Yasa explained that his company received useful technical coaching as part of a quality control process conducted upon delivery of his product to this PT. In a case of knowledge spillover, his firm applied some of these technical lessons not only to his subcontracting operations, but also to the production of retail market goods.

I 7 See for example, Rajan (2005), Palit (2006) and Palit and Nawani (2007).

I 8 See for example, Sandee (I996), Sandee and ter Wingel (2002) and Tambunan (2008). 


\section{List of references}

Blomström M. and F. Sjőholm (1999)'Technology Transfer and Spillovers: Does Local Participation with Multinationals Matter?', European Economic Review 43, 915-923.

Evans P. (1998) 'Transferable lessons? Re-examining the institutional prerequisites of East Asian economic policies', Development Studies 34(6), 66-86.

Harianto F. (1993) Study on Subcontracting in Indonesian Domestic Firms, Research report, PEP-LIPI, Jakarta.

Hayashi M. (2002) Development of SMEs in the Indonesian Economy, Mimeo, School of Economics, Faculty of Economics and Commerce, Australian $\mathrm{Na}$ tional University, Canberra.

Hsueh R.Y. (2006) 'Who Rules the International Economy? Taiwan's Daunting Attempts at Bilateralism', in Aggarwal V.K. and S. Urata (eds.) Bilateral Trade Agreements in the Asia-Pacific. Origins, Evolution, and Implications, I60-183, Contemporary Political Economy Series, Routledge, New York.

Iman M.S. and A. Nagata (2002) Institutional Coordination Problem. An Obstruction to Promotion of Industrial Backward Linkages, Mimeo, School of Knowledge Science Japan Advanced Institute of Science and Technology, Tatsunokuchi, Japan.

Islam R. (I992) (ed.) Transfer, Adoption and Diffusion of Technology for Small and Cottage Industries, ILO-ARTEP, Geneva.

JICA (2000) Study on Inter-firm Linkages and Financial Needs for the Development of Small and Medium Scale Manufacturing Industry in Indonesia, Study Report, Japan International Cooperation Agency in cooperation with PT Kami Karya Nusantara, Jakarta.

Kim L. (1995) Learning and Innovation in Economic Development, Edward Elgar, Cheltenham and Northampton.

Kim L. (1997) Imitation to Innovation: The Dynamics of Korea's Technological Learning, Harvard Business School Press, Boston.

Kirk J. and M. Miller (1986) Reliability and Validity in Qualitative Research. Sage, Beverly Hills.

Kitabata T. (1988) Report on the Subcontracting System in the Indonesian Machinery Industries, Japan International Cooperation Agency (JICA), Tokyo.

Marcotte C. and N. Jorge (2005) 'Small and Medium-sized Enterprises Involved in Technology Transfer to China. What Did Their Partners Learn?', International Small Business Journal 23(I), 27-47.

Morcos J-L. (2003) International Subcontracting versus Delocalisation? A Survey of the Literature and Case Studies from the SPX Network, Mimeo, UNIDO, Vienna. 
Nelson R.R. and H. Pack (1999) 'The Asian Growth Miracle and Modern Economic Growth', Economic Journal I09, 416-436.

Palit A. (2006) 'Role of Technological Capabilities in Enhancing FDI Flows in Developing Asia-Pacific Economies', ARTNeT Policy Brief 9, November, UNESCAP, Bangkok.

Palit A. and N. Shounkie (2007) 'Technological Capability as a Determinant of FDI Inflows: Evidence from Developing Asia \& India', Working Paper 193, April, Indian Council for Research on International Economic Relations, New Delhi.

Pantjadarma D. (2004) 'The Potential Role for an ICT Entrepreneur in Accelerating SME Development in Indonesia: The Case of the Metal Working Industries in Tegal', Journal of International Business and Entrepreneurship Development 2(2) (Special Issue), i7-24.

Rajan R.S. (2005) 'Foreign Direct Investment and the Internationalization of Production in the Asia-Pacific Region: Issues and Policy Conundrums', AsiaPacific Trade and Investment Review I(I), 3-26.

Rosenberg N. and F. Claudio (eds.) (1985), International Technology Transfer: Concept, Measures, and Comparisons, Praeger, New York.

Saggi K. (2002)'Trade, Foreign Direct Investment, and International Technology Transfer: A Survey', The World Bank Research Observer I7(2), 19I-235.

Sandee H. (1996) 'Small-Scale and Cottage Industry Clusters in Central Java: Characteristics, Research Issues, and Policy Options', Paper presented at the International Seminar on Small Scale and Micro Enterprises in Economic Development Anticipating Globalization and Free Trade, Satya Wacana Christian University, November 4-5, Salatiga.

Sandee H. and J. Wingel (2002) 'SME Cluster Development Strategies in Indonesia: What Can We Learn from Successful Clusters?', Paper presented for JICA Workshop on Strengthening Capacity of SME Clusters in Indonesia, March 5-6, Jakarta.

Sato Y. (1998) 'The Transfer of Japanese Management Technology to Indonesia', in H. Hal and W. Thee Kian (eds.) Indonesia's Technological Challenge, 326-34I, Research School of Pacific and Asian Studies, Australian National University and Institute of Southeast Asian Studies.

Sato Y. (2000) 'Linkage Formation by Small Firms: The Case of a Rural Cluster in Indonesia', Bulletin of Indonesian Economic Studies 36(I), I37-I66.

Sjöholm F. (1999a) 'Productivity Growth in Indonesia: The Role of Regional Characteristics and Direct Foreign Investment', Economic Development and Cultural Change 47(3), 559-584.

Sjöholm F. (1999b) 'Technology Gap, Competition, and Spillovers from Foreign Direct Investment: Evidence from Establishment Data', Journal of Development Studies 36, 53-73. 
SRI International (1992) Technology Development Plan for Indonesia's Engineering Industries, draft final report for the Ministry of Industry, Republic of Indonesia, Jakarta.

Supratikno H. (200I) 'Subcontracting Relationship in Indonesian Manufacturing Firms', Gadjab Mada International Journal of Business 3(2), I15-I27.

Supratikno H. (2002) The Strategies of Cluster Upgrading in Central Java, A Preliminary Report to the Ministry of Industry and Trade, March, Salatiga.

TAF (2000) Strategic Alliances and Development of Small and Medium-Scale Enterprises in Indonesia, Final Report, May, The Asia Foundation, Jakarta.

Tambunan T. (2008) Development of SMEs in ASEAN, Readworthy Publications, New Delhi.

Tarmidi L.T. (200I) Indonesian Industrial Policy for the Automobile Sector with Focus on Technology Transfer. Explanations for the Lack of Technology Transfer in Indonesia's Automobile Sector, Mimeo, Institute of International Business, Jakarta, Indonesia.

Thee Kian W. (I990a)'Indonesia: Technology Transfer in the Manufacturing Industry', in H. Soesastro and M. Pangestu (eds.) Technological Challenge in the Asia Pacific Economy, 200-232, Allen \& Unwin, Sydney.

Thee Kian W. (1990b) 'Prospects for Cooperation in Technology', in K.S. Jin and S.J. Won (eds.) Cooperation in Small and Medium-Scale Industries in ASEAN, 40-55, Asian and Pacific Development Centre, Kuala Lumpur.

Thee Kian W. (1997) 'The Development of the Motor Cycle Industry in Indonesia', in M.E. Pangestu and Y. Sato (eds.) Waves of Change in Indonesia's Manufacturing Industry, 93-III, Institute of Developing Economies (IDE), Tokyo.

Thee Kian W. (2005)'The Major Channels of International Technology Transfer to Indonesia: An Assessment', Journal of the Asia-Pacific Economy Io(2), 214236.

Thee Kian W. and M. Pangestu (1994) Technological Capabilities and Indonesia's Manufactured Exports, revised report for UNCTAD/SAREC Project on Technological Dynamism and the Export of Manufactures from Developing Countries, January.

UNCTAD (2007) The Least Developed Countries Report 2007. Knowledge, Technological Learning and Innovation for Development, United Nations, Geneva.

World Bank (2006) Revitalizing the Rural Economy: An assessment of the investment climate faced by non-farm enterprises at the District level, Consultative Draft, July, Washington, D.C.

Yin R.K. (1989) Case Study Research: Design and Methods, Sage, Beverly Hills.

Yusuf S. (2003) Innovative East Asia. The Future of Growth, World Bank and Oxford University Press, Oxford. 
Yusuf S. (2007) 'From Creativity to Innovation', Policy Research Working Paper 4262, Development Research Group, World Bank, Washington, DC.

Yusuf S.M., A. Altaf, B. Eichengreen, S. Gooptu, K. Nabeshima, Ch. Kenny, D.W. Perkins and M. Shotten (2003), Innovative East Asia: The Future of Growth, World Bank, Oxford University Press, New York. 



\title{
4 African small and medium enterprises and the challenges in global value chains
}

\author{
The case of Nigerian garment enterprises
}

\author{
Osmund Osinachi Uzor
}

\section{I Introduction}

The increased intensity of economic globalization supported by the fallen barriers to entry in production has pressured countries to improve their capabilities in industrial activities. The globalization process has accelerated the growth of world imports and exports as well as increased Foreign Direct Investment (FDI) across borders since the I980s. The concept of Global Value Chains (GVCs) refers to the interrelated production activities performed by firms at different geographic locations. The interrelated activities offer opportunities for local producers to learn from the global leaders of the chains. The internal governance of the value chain significantly affects the scope of local firms' upgrading (Giuliani et al., 2005). Multinational Corporations (MNCs) play an important role in the GVCs. The MNCs are involved in the global production and outsourcing networks that facilitate linkages. They engage in subcontracting or joint venture activities with local small and medium enterprises (SMEs) and have the ability to source products and services from a variety of vendors at various stages of their operations (UNCTAD, 2007, p. I). In some cases, the MNCs take active steps in upgrading the capabilities of their suppliers for efficient delivery of services (UNIDO, 2004, p. 5).

With exemption of South Africa, SMEs in sub-Saharan Africa are marginalized in GVCs because they lack the potential individually to improve performance. The aim of this chapter is not only to show why sub-Saharan SMEs are marginalized from the GVCs but also to analyze the challenges the SMEs in the region face in order to be integrated in the GVCs. The chapter also provides the analytical framework on how MNCs can impact transformation in African SMEs using the global value chains approach. The chapter is divided into six sections. The next section provides the methodology of the study while section three focuses on the literature review and the theoretical framework of the study. Section 
four provides the relationship between GVCs and upgrading while section five focuses on the capabilities of Aba garment producers, how MNCs can impact growth in garment industries in Nigeria as well as the challenges the garment producers face for possible integration in the GVCs. Section six concludes the chapter and provides GVCs-specific recommendations.

\subsection{The methodological limitations}

The analysis of this chapter is based on the assumptions that sub-Saharan countries can be integrated in the international production networks if they have the capability to upgrade and diversify their primary commodity products (Uzor, 2007, p. 273). It is also based on the assumption that competitiveness of small enterprises is a function of capital stock and level of technological application

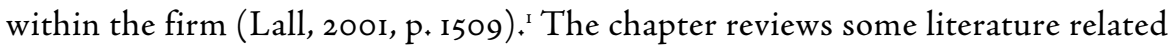
to GVCs, Global Commodity Chains (GCCs) and analyzes the capabilities of the Nigerian garment producers. In analyzing the capabilities of the SMEs garment producers in Nigeria, three indicators were used to assess the local competitiveness of garment producers. The indicators are the educational level of the enterprise's heads and workers, the level of skilled workforce and the nature of technology.

In examining the technological application in garment production, the equipment was classified into secondhand machines only, new machines only, and a mixture of new and old machines. This provides the basis for analyzing the relationship between the quality of the skills of the workforce, technology, product output and quality. The technology root in the firms sampled is assumed to be zero since all equipment is externally imported. There are no firms reported to be using locally produced machines. There is no evidence of direct linkage with the local textile industry or foreign buyers. This would suggest that garment production in Nigeria depends on import and may imply that change in trade policy may affect firm performance.

The empirical analysis of this chapter is partly based on the primary data collected from field study which contains a wide range of data. Due to the complexity of the subject, limited research data on GVCs in Nigeria and lack of effective channels of communication in Nigeria, data collection from 60 entrepreneurs and their workers in Aba, in Abia state of Nigeria, was done using face to face interviews and discussions. To validate information, discussions and interviews were conducted with private and public institutions that promote the garment industry and SMEs in the city of Aba. Due to sensitivity of some factors and reaction of the interviewees (for example profits and income), questions were con- 
stantly reframed and some were dropped in the process. One visit is not sufficient to generate reliable information, hence repeated visits were conducted in order to verify and validate information. The stratified sampling method was used because the populations are located in different parts of Aba city. It is appropriate to sample each subpopulation independently because stratification helped to group the enterprises in the population into relatively homogeneous subgroups before making a random sampling. In evaluating the pattern of the responses, the study did not apply econometrics techniques; instead the responses were presented in cross-tabulations showing the data analyses and the related outcomes.

\subsection{Overviews of literature and theoretical background}

\subsubsection{Background literature}

McCormick (1997) examined the economic activities of Kenya's garment market and its potential contribution in the country's industrialization effort. The study revealed that there are extensive weak internal and external linkages in the industrial subsector. Interfirm specialization and division of labor are totally lacking. In a few cases, the interfirm linkages are informal in nature. The producer-trader relation in the garment market is centered on access to market information. There is poor coordination and implementation of national policy on small enterprises due to poor institutional support and lack of infrastructure needed for market development. McCormick argued that productivity of the small enterprises in the garment production would have been strengthened if large and small firms in the garment industry in Kenya could explore the possibilities of mutual benefits in subcontracting relationships. The implication of her argument is that if the small producers of garments in Africa can undertake product and process upgrading, the possibility of engaging in subcontracting with global buyers can be feasible. Improving the quality of small firm output would become the subcontractor's concern because quality enhancement requires appropriate interventions.

Knorringa (1999) also used the international commodity chain approach to show the heterogeneity and trajectories of enterprises cluster in Agra, India. The analysis shows the differences between the market channel and the global commodity chain. The former according to the author illustrates the scenario where traders, producers and other relevant units are linked in the production and distribution of particular products to a specific market segment. Knorringa explains how international manufacturers and traders incorporate producers from developing countries in the supply chain. The study revealed that the market channels of a producer and producer's performance is significantly related. In 
other words, market channels that involve value chains tend to enhance producers' productivity.

In analyzing the trend in international trade and industrial upgrading in the apparel commodity chain, Gereffi (1999) used the concept of global commodity chains to explain the difference between buyer-driven and producer-driven global commodity chains. The buyer-driven commodity chains according to Gereffi refers to those industries in which large retailers, brand marketers, and brand manufacturers play the pivotal roles in setting up decentralized production networks in a variety of exporting countries typically located in developing countries. Producer-driven commodity chains are those in which large firms, especially the multinational manufacturers, play the central role in coordinating production networks. The producer-driven chains are capital- and technology-intensive industries normally found in industrialized countries. The manufacturers in producer-driven chains have the ability to exert control over backward and forward linkages existing in the chain structure. The buyer-driven commodity chains on the other hand are characterized with highly competitive, locally owned, globally dispersed production systems (Gereffi, I999, p. 43).

The UNIDO's (200I) report on integrating SMEs in global value chains recognized the role SMEs can play in promoting industrial and economic development in developing countries. The report prepared by Kaplinsky and Readmann emphasized the importance of capacity upgrading in terms of product, process, functional and chain upgrading. The argument here is that MNCs have integrated their production systems across the globe to ensure compatibility along the chains (Kapinsky and Readmann, 200I, p. 3I). The implication here is that for local SMEs in the region to be integrated in GVCs, the policymakers in the region have to restructure their industrial development strategies towards capability upgrading.

Bair and Gereffi (200I) analyzed the dynamics of industrial transformation in Torreon, Mexico after the creation of the North American Free Trade Association (NAFTA). The analytical framework is based on the concepts of Industrial District and GCC. The findings revealed that inserting the firms in Torreon in the GCC led to upgrading and improving performance. Consequently, firms in the district moved from a full-package production system that lacked the capacity for process upgrading to GCC that set conditions for quality upgrading. This subsequently led to an export and employment boom in the region.

Humphrey and Schmitz (2004) analyzed the governance in global value chains and showed how firms in the chains set and/or enforce the quality parameters under which others in the chain must follow and operate. The analysis suggests that even when developing countries liberalize their markets, entry to the global value chains or access to external markets is not automatic. The essence of gov- 
ernance in the GVCs therefore is to ensure that the necessary quality systems are in place. The main function of the governance structure is to transmit information about the quality parameters and enforce compliance.

UNIDO (2004) applied the GVC and Global Production Network (GPN) approaches in analyzing the opportunities for and challenges in industrial upgrading. The analysis is centered on the opportunities created for local firms in the GVCs and GPNs. The former refer to the ability to source products and services from different vendors across the globe. The latter concern production networks with interconnected functions and operations across borders through which goods and services are produced and distributed. Such networks support integration of firms into structures and the national economies to reap enormous economic advantages derived from GVCs. In general, participation in the GVCs and GPNs broadens the scope of access to international trade and attract investment in the local market.

Kudi, Akpoko and Abdulsalam (2007) used the local commodity chain approach to identify and analyze the constraints in production and marketing processes in the cotton production in Nigeria. The analysis shows the impact of commodity marketing processes that change from the peasant farmers, merchants, spinning industries to textile and export. Uzor (2007) also analyzed the local value chain in Palm Kernel Oil extraction in Nigeria. The analysis showed how the rural and urban economies are integrated in a production process in order to add values and create wealth.

The OECD (2008) report on the role of SMEs in GVCs shows why firms in developed and developing countries need to meet specifications in terms of international standards and systems. The report argues that strategic partners should meet future demand because the quality of the relationship between international contractors, partners and suppliers are crucial in global value chains. In other words, a sustainable linkage between SMEs and MNCs is one of the most effective ways to integrate domestic suppliers into GVCs. The challenge facing SMEs in Africa is how to meet international standards and be part of the GVC systems. OECD (2008) further argues that participation of SMEs in developing countries in GVCs will generate numerous advantages for the firms and economies in general. The advantages comprise entry to foreign markets, earnings of foreign currencies, diversification of exports to the upgrading of skills and knowledge of the local workers as well as improving technological applications production. Such advantages are necessary for productivity enhancement and economic growth. In this context, the challenge facing the policymakers in Africa is how garment producers in the region can improve capabilities and have access to the chains' lead firms, either directly as a first-tier supplier (or subaltern), or indirectly as a second-tier supplier. 


\subsubsection{Theoretical background}

The concept of value chain is based on Porter's (1985) idea of manufacturing (or service) as an organization system comprising subsystems that involve inputs, transformation processes and outputs. The activities carried out in the value chain determine the costs which have effects on the organization's profits. The activities are classified into primary and supportive. The primary activities are those that enable the firm to fulfil its role in the value and to satisfy customers' desires. The supportive activities are the necessary activities that are aimed at improving business performance over time and at the same time add values indirectly (OECD, 2008). Value chain can be defined as the process which is required to bring a product or service from its conception, through the intermediary phases of production, then delivery to the final consumers and to finally be disposed off after use (Kaplinsky, 2000 , p. 12I). OECD (2008, p. 9) argues that an organization can gain a competitive advantage over its competitors if it can manage effectively the entire value chain. A value chain can be contained within a single firm or divided among different firms which can be contained within a single geographical location or spread over wider areas. The GVC concerns value chains that are divided among multiple firms and spread across wide geographic space (Humphrey and Schmitz, 2000). How to reduce uncertainty has been the most critical aspect of GVCs. To reduce uncertainty in the entire value chain system, there is a need for value chain governance'. Governance in this context implies all efforts directly or indirectly that are aimed at reducing any form of uncertainty in the system. The major objective of the governance in the GVC is to maintain an effective cooperation among the key actors in the chain. Firms or groups of firms can define and enforce the parameters for the operations in the value chains such that sustainability of transactions within the chains can effectively be maintained (OECD, 2008, p. 9).

There is a conceptual difference between the global value chains and global commodity chains. The GCC consist of sets of interorganizational networks clustered around one commodity or product, linking households, enterprises and states to one another within the world economy (Gereffi and Korzeniewicz, 1994, p. 2). GVC analysis focuses on cross-border linkages between firms in global production and distribution systems. It also laid emphasis on governance through non-market relations which is an important factor that aids generation, transfer and diffusion of knowledge for firms to improve their performance and to upgrade (Humphrey and Schmitz, 2004, p. 97). Both GVCs and GCCs emphasize the importance of product quality upgrading (Kaplinsky and Readman, 20oI, p. 29; Gereffi and Memedovic, 2003, p. 4). GVCs proponents argue that for SMEs in the developing countries to maintain increased income as globalization pressure persists, they must upgrade by increasing the skill content of their activities 
(Humphrey and Schmitz, 2002, p. 1018). The role by governance in the upgrading of local firms is to coordinate the economic activities through non-market relationships with the aim to facilitate relations with the external world (Humphrey and Schmitz, 2002, p. 1018). Under the GVCs framework, upgrading can occur through learning by doing or by allocation of new tasks by the chain's leading firm.

Inserting African SMEs garment producers in the global value chain requires an institutionalized framework that encourages learning. Such a framework requires measures geared towards creation of awareness and understanding the structure and dynamics of GVCs across firms and sectors. GVC is a complex configuration and SMEs in Africa have limited information about how the value chain operates: there is a need for effective GVC 'brokers'. The main functions of the brokers are to identify the sectoral and branch specific positions, the capability level for African SMEs participation and the structure of the linkages. Moreover, African SMEs lack the financial resources, in-house technological capability to upgrade and the managerial capability necessary in complex global production networks. It is the function of the value chain brokers to source the funds, and initiate and organize measures to reduce the capability gaps in the SMEs. Furthermore, effective participation in GVCs requires effective government intervention in the area of skill upgrading and regulatory framework on intellectual property rights (IPRs).

\subsection{Global value chains and the challenges in upgrading African small and medium enterprise garment producers}

Upgrading along the value chain can be, for example, in the form of moving from cotton production to textile manufacturing or garment manufacturing. In the garment industry, upgrading can follow a systematic process in terms of moving from ordinary equipment manufacture (OEM) to ordinary design manufacture $(\mathrm{ODM})$, or from ODM to ordinary brand manufacture (OBM). OEM is full package production in which the supplier takes on a broader range of manufacturing functions, including sourcing of inputs and logistics, while the buyer is responsible for designing and marketing. In ODM the supplier carries out parts of the design process, possibly in collaboration with the buyer. Upgrading to OBM implies that the supplier undertakes designing and producing, as well as marketing its own products under its own brand (Humphrey, 2004, p. 7). The idea of upgrading refers to how to improve and make better products more efficiently or move into more skilled activities as put forward by literature on competitiveness (Porter, 1990; Kaplinsky, 2000). In general, upgrading is strictly related to innovation which involves process, product and organizational innovation. Upgrading as innovating can be defined as to increase value added. Enterprises may achieve 
this in various ways, for example by entering higher unit value market niches, by entering new sectors, or by undertaking new productive (or service) functions (Humphrey and Schmitz, 2002, p. I018). This requires gradual improvement of products and processes, and continued and consistent investment in technological capabilities (Lall, 1992, p. 9; Pietrobelli, 1998, p. 16). Innovation is relative in the sense that a firm or a cluster of firms upgrade when they innovate faster than their competitors. This involves reorganizing activities, products and sectors in order to sustain higher value added and enforce higher entry barriers (Humphrey and Schmitz, 2000, p. 3).

Process upgrading is the process of transforming inputs into outputs more efficiently by reorganizing the production system or introducing superior technology (Humphrey and Schmitz, 200o, p. 3). The transformation that took place in footwear producers in Sinos Valley, Brazil, can be taken as an example. The firms in the cluster reorganized their production system that adopted a just-intime production system in terms of reliability and faster production. The firms overcome competitive pressure and market their products quicker than the competitors (Schmitz, 1999, p. 1628). Product upgrading is moving into more sophisticated product lines in terms of increased unit values (Humphrey and Schmitz, $2000, \mathrm{p} .4$ ). For example, the apparel commodity chain in Asia was upgraded from discount chains to department stores (Gereffi, 1999, pp. 6-7). Functional upgrading is acquiring new, superior functions in the chain, such as design or marketing or abandoning existing low value-added functions to focus on higher value-added activities (Humphrey and Schmitz, 2000, p. 4). For example, Torreon's blue jeans industry was upgraded from maquila (in bond plants) to 'full-package' exportoriented apparel production (Bair and Gereffi, 200I, p. I892).

Figure 4.I shows the annual cotton production output in four selected African countries. As shown in the figure, the output in Egypt declined drastically from $2428 \mathrm{lb}$. bales in 1980 to $920 \mathrm{lb}$. bales in $2003(62.1 \%)$ but increased from $920 \mathrm{lb}$. bales in 2003 to $1050 \mathrm{lb}$. bales in 2007 (12.4\%). In Mali, the second largest producer of cotton in Africa after Egypt, cotton production output increased from $37 \mathrm{lb}$. bales in 1967 to $775 \mathrm{lb}$. bales in 1995 . The production output declined from $775 \mathrm{lb}$. bales in 1995 to $480 \mathrm{lb}$. bales in $2000(38.1 \%)$ and subsequently increased from $480 \mathrm{lb}$. bales in 2000 to $\mathrm{I} 200 \mathrm{lb}$. bales in 2003 ( $150 \%$ ) but fell from $\mathrm{I} 200 \mathrm{lb}$. bales in 2003 to $475 \mathrm{lb}$. bales in 2007. In Cameroon, the production output has shown a dynamic growth from 1960 to 2004 , which represents the turning point. The annual production output declined from $500 \mathrm{lb}$. bales in 2004 to $275 \mathrm{lb}$. bales in 2007 (45\%). In Nigeria, the cotton production output is not relatively stable. Between 1960 and 1975 the output declined from $260 \mathrm{lb}$. bales in 1960 to $180 \mathrm{lb}$. bales in $1970(30.8 \%)$ but increased from $180 \mathrm{lb}$. bales in 1970 to $280 \mathrm{lb}$. bales in $1975(55.6 \%)$ and declined to its lowest of $46 \mathrm{lb}$. bales in 1985. 
Figure 4.1 Cotton production in some selected African countries, lb. Bales

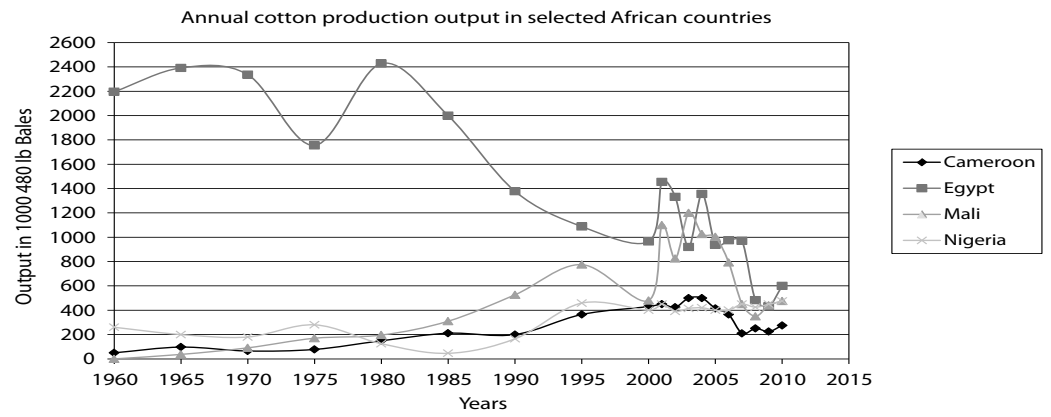

Source: USAD, 2009

As shown in Figure 4.2, the cotton export followed the same pattern of production output with Egypt losing its export position to Mali between 1990 and 2006. Nigeria on the other hand recorded zero export in the cotton subsector between 1975 and 1995. Several factors led to the decline in output of cotton in Africa. In Mali, the devaluation of the currency produced a positive impact on the production and export of cotton. This was jeopardized by a world price drop in 2000-200I, as well as increasing the subsidization of local production in USA and China. Consequently, the cotton price plunged from 9i cents per pound on average in 1994-1995 to 52 cents per pound in 2004-2005 (USDA, 2005).

Figure 4.2 Cotton export volume in some selected African countries, Ib.bales

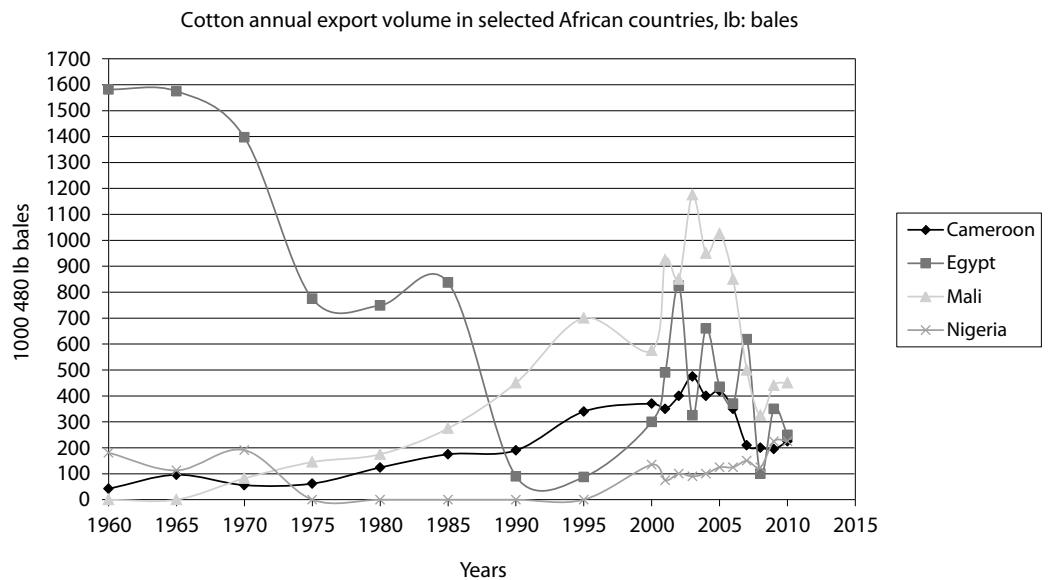

Source: USAD, 2009 
Nigeria has lost its competition and comparative advantage in cotton production and export arguably due to overdependency on the oil sector. The challenge $\mathrm{Ni}$ geria is facing is how to upgrade and insert its SME garment manufacturer in the GVCs. It is imperative for Nigeria to redirect its industrial development strategies towards upgrading the garment industrial subsector and take advantage of its labor surplus. As argued by Krugman (1996), countries are bound to benefit economically from international specialization, provided that it is consistent with their pattern of comparative advantages.

Furthermore, Nigerian government trade policies can affect the aims of GVCs. For example, the structure of tariffs indicate the level of protection or the level at which competition is stimulated in the economy. The I995-200I tariff structure in Nigeria was designed to stimulate competition and efficiency by reducing tariffs on consumer goods items relative to tariffs on raw materials and intermediate and capital goods. The aim of the government to reduce tariffs was to expose domestic manufacturers to import competition (World Bank, 2002, p. I0). The relatively higher tariffs on raw materials were aimed at encouraging investment into raw materials and intermediate goods production. This was counter-productive because the Nigerian government failed to encourage investment in raw material research. However, the level of protection in Nigeria has reduced to a certain degree but generally, the tariffs are still high compared to world averages (World Bank, 2002, p. I0). In 2005, the tariff binding coverage was $19.2 \%$ of total imports. ${ }^{2}$ The simple average of ad valorem duties for Most Favored Nation (MFN) applied in 2006 for all goods and agricultural goods were I2 and 15.6\% respectively, while the tariff for non-agricultural goods was 1 II. $4 \%$ (Trade Policy Review, 2005). The implication of high tariffs above the world averages in a GVCs framework is that the cost of inputs for locally manufactured commodities will rise, thereby affecting the competitiveness of the garment products in the chain negatively.

\subsection{The capabilities of small and medium enterprises in garment producers in Aba}

\subsubsection{Historical background}

Garment manufacturing in Aba is directly linked to migrants from Bende communities and has a history dating back to colonial times. Bende is a colonial district in the eastern region of Nigeria located in the present northeastern part of Abia State, Nigeria. The formation of a garment manufacturing cluster in Aba town began when migrants with specialized skills in weaving and tailoring expanded in the area that was settled by Bende indigenes. The workshops were 
located within the residential areas of the entrepreneurs which later formed the nucleus of the cluster (Meagher, 2005, p. 8). ${ }^{3}$ Vocational training in weaving and sewing initiated by early missionaries for women in the Bende provided the background skill development in tailoring. The traditional cotton-producing areas in the northwestern subregion of Nigeria are Kaduna, Katsina, Zamfara, Sokoto and Kebbi states. The cotton production in the northern states of $\mathrm{Ni}$ geria is the main supplier of yarns to the traditional 'Akwete' women weavers in Aba since the early 1900s. By 1946 about 668 women weavers were producing high-grade cotton cloth in the southeastern region of Nigeria (Chuku, 2005, p. 138). Other weaving centers in the then eastern provinces were located at Nsukka, Udi and Abakilki (Chuku, 2005, p. I4I). The imported high-quality yarns reduced the demand of locally produced yarn from northern Nigeria. Increased demand of western-style garment production led to a decline of the Akwete weavers' products.

\subsubsection{Competitive factors in Aba small and medium scale garment enterprises cluster}

Economists consider competitiveness based on a macroeconomic framework in terms of real exchange rate, full employment, and persistent current account position. The measure of competitiveness in this context is the relative price or cost indices expressed in tradable currencies (Boltho, 1996, p. 3). The second consideration is based on the well-being of the citizens of a country (human capital stock) which has an effect on medium- and long-term economic performance (Fagerberg, 1996, p. 40). The latter can be referred to as a competitive lag which Lall and Kraemer-Mbula (2005, pp. 55-56) considered a problem in African garment manufacturing. Firm upgrading as a result of innovative performance depends on the educational attendance level of workers and the entrepreneurs. Education is extremely important for innovation and growth because human capital plays an important role in technology diffusion (Baumol, 2004). This is also fundamental in GVC's operation in terms of the level skill development. As shown in Table 4.I, the educational level of enterprise heads did not change significantly with firm size. $67.2 \%$ of workers and enterprise heads of the total sample had attained primary education while $31.8 \%$ had attained secondary education. 
Table 4.1 Educational level of entrepreneurs and workers expressed in percentage of sample number across firm size

\begin{tabular}{|c|c|c|c|c|}
\hline Sample objects sample no. & $\begin{array}{l}\text { Primary } \\
\text { education }\end{array}$ & $\begin{array}{l}\text { Secondary } \\
\text { education }\end{array}$ & $\begin{array}{l}\text { Post } \\
\text { secondary } \\
\text { education }\end{array}$ & $\begin{array}{l}\text { Formal } \\
\text { skilled tailors }\end{array}$ \\
\hline Enterprise heads & No. (\%) & No. (\%) & No. (\%) & No. (\%) \\
\hline Micro 34 & $24(70.5)$ & $8(23.5)$ & $1(2.9)$ & $24(70.0)$ \\
\hline Small 20 & $12(60.0)$ & $7(35.0)$ & $2(10.0)$ & $13(65.0)$ \\
\hline Medium 6 & $2(33.3)$ & $4(66.7)$ & & 0 \\
\hline \multicolumn{5}{|l|}{ Manager } \\
\hline Micro 34 & $24(70.6)$ & $10(47.1)$ & 0 & $20(58.8)$ \\
\hline Small 20 & $14(70.0)$ & $6(30.0)$ & 0 & $12(60.0)$ \\
\hline Medium 6 & $1(16.7)$ & $5(83.3)$ & 0 & 0 \\
\hline \multicolumn{5}{|l|}{ All workers including manager } \\
\hline Micro 92 & $60(65.2)$ & $32(35.6)$ & 0 & $64(69.6)$ \\
\hline Small 48 & $32(66.7)$ & $16(33.3)$ & 0 & $24(54.2)$ \\
\hline Medium 74 & $54(73.0)$ & $20(27.0)$ & 0 & $46(62.2)$ \\
\hline Sample Total 274 & $184(67.2)$ & $87(31.8)$ & $3(0.7)$ & \\
\hline Total skilled tailors & $132(71.7)^{*}$ & $57(65.5)^{*}$ & 0 & \\
\hline $\begin{array}{l}\text { Including managers } 191 \\
\text { and enterprise heads }\end{array}$ & $(48.2)^{* *}$ & $(20.8)^{* *}$ & & $191(69.7)$ \\
\hline
\end{tabular}

Note: ${ }^{*}=$ expressed as percentage of the total number of those that had primary or secondary education; ${ }^{* *}=$ expressed as percentage of sample total.

Source: Uzor, 2009

Only $2.9 \%$ of enterprise heads in microenterprises were educated beyond secondary school. Table 4.1 also shows that $70 \%$ and $65 \%$ of entrepreneurs in micro and small enterprises respectively had vocational training in tailoring.

Over the sample, $69.7 \%$ of the workers and entrepreneurs are trained tailors. The scenario however portrayed a different picture when the educational level of skilled tailors including the entrepreneurs and workers were considered. The total number of skilled tailors (including entrepreneurs and managers) expressed as a percentage of the total number of those who attained primary and secondary education is $71.7 \%$ and $65.5 \%$ respectively. Expressed as a percentage of the total sample, $48.2 \%$ of the skilled tailors attained primary education while $20.8 \%$ received secondary education.

Table 4.2 shows the technological base and linkages in and nature of innovative activities in the Aba garment enterprises cluster. The use of old and outdated machines as opposed to new machines results in financial limitations for the firms. Low investment in modern technology has led to high internalization of production and weak firm linkages in the sector, as well as poor product output. 
This suggests that firms in the cluster lack the required technological capability for effective operation as required in the GVC. The process of innovation identified in the sector is such that entrepreneurs and traders organize and control the distribution of garment products within established market channels to reduce excess production. In general, the process innovation in the clusters is associated with problems similar to 'around the edges' and 'black box' syndrome. The former suggests that the authorities only perceive the entrepreneurship talent (outcome) but ignore the problems faced by the entrepreneurs. The latter means that authorities fail to understand the details of the innovative process in the clusters or what to do in order to upgrade the subsectors. Product innovation in the cluster is such that new product designs are introduced in the market using new raw materials. The innovative activity can be regarded as a survival strategy that keeps prices low in order to withstand competitive pressure. The firm tried to reposition their survival strategy with a low degree of technical change which resulted in slow growth. The competitiveness in the Aba garment industry is based on a strategy that focuses on sales maximization through closed networks. The implication here is that government policy should focus on factors that will increase productivity of the firms and access to technology to upgrade the sector for possible integration of the firms in the GVCs.

Table 4.2 The level of technology and linkages in clusters in the Aba garment industrial cluster

\begin{tabular}{lll}
\hline Upgrading variables & Characteristics & Remarks \\
\hline $\begin{array}{l}\text { Nature of } \\
\text { technology }\end{array}$ & Old and outdated & $\begin{array}{l}\text { Low investment on modern } \\
\text { technology }\end{array}$ \\
\hline $\begin{array}{l}\text { Nature of } \\
\text { linkages }\end{array}$ & $\begin{array}{l}\text { Very weak linkages and } \\
\text { internalization } \\
\text { Absence of institutional } \\
\text { support } \\
\text { and technology linkages }\end{array}$ & $\begin{array}{l}\text { Absence of linkages with } \\
\text { external buyers }\end{array}$ \\
\hline $\begin{array}{l}\text { Innovative activity } \\
\text { (Process) }\end{array}$ & $\begin{array}{l}\text { Different methods of } \\
\text { supplying the market }\end{array}$ & $\begin{array}{l}\text { 'Around the edges' and 'black } \\
\text { box' syndrome }\end{array}$ \\
\hline $\begin{array}{l}\text { Innovative activity } \\
\text { (Product) }\end{array}$ & $\begin{array}{l}\text { New product designs and use } \\
\text { of new materials }\end{array}$ & $\begin{array}{l}\text { Cost reduction and } \\
\text { repositioning }\end{array}$ \\
\hline $\begin{array}{l}\text { Competitive } \\
\text { strategy }\end{array}$ & Closed networks & $\begin{array}{l}\text { Low degree of technical } \\
\text { change }\end{array}$ \\
\hline
\end{tabular}

Source: Own field survey 
The weak competitive capability in Nigeria's garment manufacturing industry has implication for the general well-being and economic growth. Improved employment rates in the sector would have served as a means to reduce poverty. Nigeria will continue to experience the Dutch Disease since crude petroleum continues to be the dominant industrial output at the expense of manufacturing and other sectors. Nigeria has failed to diversify the economy from its overdependence on the capital-intensive oil sector which provides $20 \%$ of the country's GDP, $95 \%$ of foreign earnings and about $65 \%$ of budgetary revenue. The share of the non-oil sector in total export has never been stable and currently lies below 6\% (CBN, 2007). The foreign earnings from the oil sector have resulted in raising incomes and inflation, which have a negative effect on the exchange rate and arguably has weakened the manufacturing sector.

\subsubsection{The multinational corporations and growth in the Aba garment industry: A global value chain approach}

The growth in the Aba garment industry can be measured in terms of higher wages and an employment increase. MNCs can impact growth in the subsector through linkages in respect to international subcontracting and joint venture activities. Table 4.3 highlights the income situation in Aba small enterprises garment production. There are no differences in wage earnings in micro and small enterprises in the subsector. Over the sample, the average cash earnings in garment enterprises are below the minimum wage of USD 50 for the private sector in Nigeria. Low wages in the garment industry suggests that the subsector cannot sustain employment and there is a need to upgrade the GVCs approach. Lack of internationalization of the Nigerian SMEs in the garment sector has resulted in poor product quality and improved value added. Several factors are responsible for the lack of internationalization of the sector. The major constraint is the limitation of access to modern technology. The entrepreneurs failed to develop explicit strategies on how to access technology through international collaboration. Lack of technological development and diffusion in the subsector is a result of the absence of governmental and institutional support. The local institutions in the region have limited knowledge regarding international issues, on how to support firms, their marketing strategies on a global scale and how to be integrated in international subcontracting. Moreover, the SMEs in the region lack the financial capacity to engage in GVC processes because the cost of internationalization is relatively high. 
Table 4.3 Average monthly wage earnings of entrepreneurs and workers in Aba's small and medium scale garment enterprises (in USD) ${ }^{4}$

\begin{tabular}{lrcc}
\hline Variables & Micro & Small & Medium \\
\hline Average wage earning of enterprises heads & 77.52 & 77.52 & 116.27 \\
Paid skilled workers & 31.01 & 31.01 & 34.88 \\
Paid unskilled workers & 23.26 & 23.26 & 27.13 \\
Apprentices allowance & 7.75 & 7.75 & 0.0 \\
Average cash earnings & 34.89 & 34.89 & 44.57 \\
\hline
\end{tabular}

Source: Uzor, 2009

Apart from the barriers and challenges associated with internationalization, the SMEs face infrastructural and other growth constraints. Government and donor support play an important role in facilitating GVC. The growth problem in Aba's small and medium scale garment enterprises is not only due to internal constraints but also due to several external factors facing the sub-sector. Entrepreneurs were asked to name the major factors that hinder production activities. The responses indicated common problems but divergent in perceptions. Figure 4.3 shows that $89 \%$ of the entrepreneurs interviewed linked the problem of poor infrastructure to the case of neglect by the government authorities. The dilapidated nature of the access roads and frequent power failures essential for production are often cited as examples. More than $96.4 \%$ of the interviewees gave government trade policy as the reason for shortage of raw materials. They argued that import restrictions on foreign inputs have paralyzed the production activities in Nigeria's apparel industry. Most of the local textile industries were forced out of production due to the low quality of products that can no longer compete in current Nigeria's fashion industry.

Figure 4.3 Distribution of interviewees' perceptions of their major constraints in Aba SME garment enterprises cluster expressed in \%

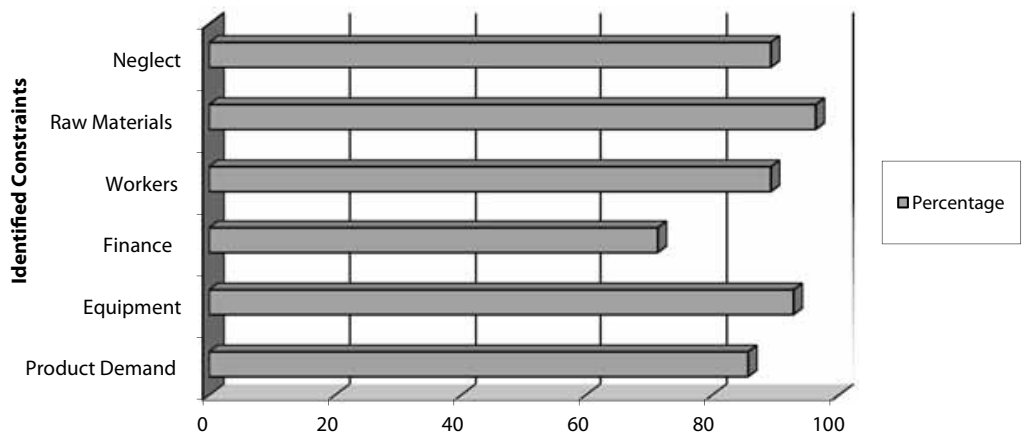

Source: Own field survey 
The interviewees were asked if liberalization measures had any effect on their firm performance. $92.9 \%$ of the interviewees insisted that the nature of technological application had been the major problem in the subsector. They argued that since their financial situation could not afford modern equipment, they had to rely on old secondhand equipment. $89.3 \%$ of the interviewees considered the shortage of skilled workers and the educational level of the skilled workers as a major problem. $85.7 \%$ of the entrepreneurs interviewed linked local demand of their products to price and quality such that those consumers who could not afford foreign products resorted to locally produced ones. $71.4 \%$ of the interviewees insisted that product upgrading in the subsector was limited, partly due to financial constraints to acquire modern equipment and partly due to the present low level of the skilled workforce.

\subsubsection{Integration of Nigerian small and medium enterprise garment producers in the global value chains}

Integration of SMEs in the GVCs can be feasible through linkages with larger firms and global buyers. This is a potential benefit for the SMEs in Nigeria and for the country in global trade. The Aba SME garment producers face two challenges in order to engage in subcontracting with global buyers. The first is understanding the impact of international competition and how to engage in GVCs. The second is to understand how to engage process and product innovation by improving capabilities. The GVC approach will help the garment producers in the region to understand how strategic relationships with key external actors function. Integrating the SME garment producers in the region in the GVCs not only shifts the emphasis from manufacturing but is also significant for marketing and logistics. This includes distributing and marketing the supply of goods and services which contributes to an increased total value added (Wood, 200I).

As put forward by McCormick (1997), engaging with global buyers will not only increase the international division of labor and facilitate the access to market information for local garment producers, but will also force the garment producers in the region to engage in process and product upgrading. The question is how to strengthen the product and process upgrading in the subsector and how to link the Nigerian garment producers to global buyers. The first step would be to address numerous internal and external obstacles that limit the capability of the garment producers to upgrade. The barriers include poor internal capabilities and resources, as well as difficulties in identifying foreign business opportunities and accessing export distribution channels, followed by the removal of the barriers to access the international market. Trade liberalization has increased the ability of well-established international manufacturers and retailers to penetrate the 
remote and underdeveloped market in Africa. Linking the local garment producers will compel them to conform to international standards. This requires investment technology in quality improvement and delivery which the GVCs demand. It also requires government provision of infrastructure and incentives that can induce FDI initiatives in the garment sector in Nigeria. Furthermore, network relationships that are not based on ownership serve as a mechanism of coordination between firms have gained importance in global value chains. Such networks where the lead firms act as governors in the chain help to set product and process standards, quality and terms of delivery (Humphrey and Schmitz, 2004, p. 104).

\subsection{Conclusions and recommendations}

The African garment subsector is dominated by micro- and small enterprises operating in the informal economy as is indicated in the literature review and empirical analyses. Policies should focus on how the capability gap in micro and small enterprises can be narrowed so that linkages with large firms and global buyers can be feasible. The garment enterprises have failed to identify market niches effectively and cannot maintain the quality standard with the changing test. The internal constraints identified in the subsector are low-skilled workers and technology problems. The firms use obsolete machines with a high energy consumption rate. The linkages in garment enterprises are not innovative enough in finding solutions to the market changes so that they fail to achieve economies of scale. The entrepreneurs have not been able to forge collective action in order to improve quality so that access to large external buyers can be feasible. The government has not come up with any articulated policy incentives aimed at promoting garment manufacturing in Nigeria. In general, the value chain starts from the primary activities supported by supportive activities, hence upgrading the production output in the cotton subsector. Investment in new technology and human capital development are the fundamental determinants of integration of African countries and SMEs in the region in the GVCs and GPNs.

New policy design is necessary to promote integration of African SME garment producers in the GVCs. Several policy options are open for policymakers in the region. Capability upgrading should come first because GVCs involve linkages with external buyers or foreign large firms. The policy strategy should focus on improving or upgrading the capabilities of SMEs. The aim here is to improve productivity and product quality. GVC enhances information filtering and compliance to standards, knowledge diffusion and structural flexibility, which are all very important for innovation and technological adaptation. Policies designed to promote linkages are indirect methods of enforcing compliance to standards 
and upgrading the entire economy. Promoting linkages or GVCs implies initiating projects that are aimed at encouraging interactions or relationships between firms across borders. Linkage will compel local SMEs in the garment production to learn how to improve quality standard as well as increase the capacity of firms to innovate.

Furthermore, strengthening the legal legislation is an essential factor in GVCs participation. Although firms use their linkages to enforce contract discipline, the development of the legal system is the only sufficient measure to install confidence in an economy. Social networks as shown by the Aba garment producers, lead to exclusion and limit competition. Strengthening the commercial law and legal institutions will serve as the basic instrument for protection enforcement of contractual relationship. Effective institutional mechanisms that are transparent and functional in terms of specifying and protecting investments are crucial for much needed confidence for FDI and GVCs as well as incentives for local investors.

\section{Notes}

I The capital stock includes level of education, workforce skills and attitude, and managerial talent. Other forms of capital stock are the quality of legal interventions, regulatory practices governing business as well as social capital that contribute to the quality of overall capital stock. Technology includes the technological knowledge embedded in the nation's scientific and technological institutions as well as those rooted in the firm (Lall, 200I, p. I509). In this study we considered two aspects of capital stocks, namely educational level, the skill of the workforce and the regulatory practices.

2 The tariff binding coverage corresponds to the number of the Harmonized System (HS) subheadings containing at least one bound tariff line.

3 This is confirmed by the author's field survey and an interview with Divine Heat, Secretary of the Aba garment producers cooperative union.

4 Workers' wages were computed on the basis of their monthly wages, the enterprise heads' incomes were calculated based on personal out-of-pocket weekly expenses, monthly expenditure on housing, family maintenance upkeep, plus average monthly savings. The Naira equivalent of USD is based on an exchange rate of USD i to N 129.00 (30 December 2007).

\section{List of references}

Bair J. and G. Gereffi (200I) 'Local Clusters in Global Chains: The Causes and Consequences of Export Dynamism in Torreon's Blue Jeans Industry', World Development 29(I), I885-1903. 
Baumol W.J. (2004) 'Education for Innovation: Entrepreneurial Breakthroughs vs. Corporate Incremental Improvements', National Bureau for Economic Research (NBER) Working Paper 10578, Cambridge, Mass.

Boltho A. (1996) 'The Assessment: International Competitiveness', Oxford Review of Economic Policy I2(3), I-I6.

CBN (2007) Statistical Bulletin, Financial Statistics State Bulletin I8, The Central Bank of Nigeria, Abuja.

Chuku G. (2005) Igbo Women and Economic Transformation in Southeastern Nigeria, 1900-1960, Routledge, New York.

Fagerberg J. (1996) 'Technology and Competitiveness', Oxford Review of Economic Policy I2(3), 39-5I.

Gereffi G. (1999) 'International Trade and Industrial Upgrading in the Apparel Commodity Chain', Journal of International Economics 48, 37-70.

Gereffi G. and M. Korzeniewicz (1994) Commodity Chains and Global Capitalism, Praeger, Westport.

Gereffi G. and O. Memedovic (2003) The Global Apparel Value Chain: What Prospects for Upgrading by Developing Countries, UNIDO, Vienna.

Giuliani E., C. Pietrobelli and R. Rabellotti (2005) 'Upgrading in Global Value Chains: Lessons from Latin American Clusters', World Development 33(4), 549-573.

Humphrey J. and H. Schmitz (2000) 'Governance and Upgrading: Linking Industrial Cluster and Global Value Chain Research', IDS Working Paper i2o, Institute of Development Studies, University of Sussex, Brighton.

Humphrey J. and H.Schmitz (2002) 'How Does Inserting in Global Value Chains Affect Upgrading in Industrial Clusters?' IDS, University of Sussex, Brighton.

Humphrey J. (2004) 'Upgrading in Global Value Chains', Working Paper 28, Policy Integration Department, World Commission on the Social Dimension of Globalization, International Labour Office, Geneva.

Humphrey J. and H. Schmitz (2004) 'Governance in Global Value Chains', in H. Schmitz (ed.) Local Enterprises in the Global Economy, E. Elgar, Cheltenham.

Kaplinsky R. (2000) 'Globalisation and Unequalisation: What Can Be Learned from Value Chain Analysis?', The Journal of Development Studies 37(2), I17-I46.

Kaplinsky R. and J. Readman (200I) Integrating SMEs in Global Value Chains: Towards Partnership for Development, UNIDO, Vienna.

Knorringa P. (1999) 'Agra. An Old Cluster Facing the New Competition', World Development 27(9), I587-1604.

Krugman P. (1996) 'Making Sense of the Competitiveness Debate', Oxford Review of Economic Policy 12(3), 17-25.

Kudi T.M., J.G. Akpoko and Z. Abdulsalam (2007) Assessment of the Cotton Industry Using the Global Commodity Chain Analysis Approach in Katsina State of Nigeria', Journal of Applied Sciences 7(222), 3557-3561. 
Lall S. (1992) 'Technological Capabilities and Industrialization', World Development $20(2), 165-186$.

Lall S. (200I) 'Competitiveness Indices and Developing Countries: An Economic Evaluation of the Global Competitiveness Report', World Development 29(9), 1501-1525.

Lall S. and E. Kraemer-Mbula (2005) Industrial Competitiveness in Africa. Lessons from East Africa, Schumacher Centre for Technology and Development, ITDG Publishing, Bourton Hall.

McCormick D. (1997) 'Industrial District or Garment Ghetto? Nairo's MiniManufacturing', in M.P. van Dijk and R. Rabellotti (eds.) Enterprise Clusters and Networks in Developing Countries, I09-130, Frank Cass, London.

Meagher K. (2005) 'Social Networks and Economic Ungovernance in African Small Firm Clusters', Queen Elizabeth House, Paper for the QEH 5oth Birthday Conference, www.qeh.ox.ac.uk/pdf/qehconf/meagher.pdf (Accessed in September 2006).

OECD (2008) Enhancing the Role of SMEs in Global Value Chains, OECD Publishing, Paris.

Pietrobelli C. (1998) Industry, Competitiveness and Technological Capabilities in Chile. A New Tiger from Latin America?, MacMillan, London.

Porter M. (1985) Competitive Advantage: Creating and Sustaining Superior Performance, Free Press, New York.

Porter M. (1990) The Competitive Advantage of Nations, Macmillan, London and Basingstoke.

Schmitz H. (1999) 'Global Competition and Local Cooperation: Success and Failure in the Sinos Valley, Brazil', World Development 27(9), i627-1650.

Trade Policy Review (2005) www.expot.com/profiledwn/Africa/Nigeria\%2o Trade\%2oProfile.pdf. (Accessed in March 2009).

UNCTAD (2007) Expert Meeting on Increasing the Participation of Developing Countries' SMEs into Global Value Chains, 18-19 October 2007, Geneva.

UNIDO (200I) Development of Clusters and Networks of SMEs, The UNIDO Program, Private Sector Development Branch, UNIDO, Vienna.

UNIDO (2004) Partnership for Small Enterprise Development, A joint UNIDO and UNDP Production, Prepared by Deloitte, UNIDO, Vienna.

USAD (2005) United State Department of Agricultural, Country Yearly Production Output and Export, www.indexmundi.com/agriculture/Country (Accessed in March 2009).

USAD (2009) United State Department of Agricultural, Country Yearly Production Output and Export, www.indexmundi.com/agriculture/Country (Accessed in March 2009).

Uzor O.O. (2007) 'Oil Palm Production in Nigeria and the Improved Export Chances: The Need for Upgrading', in K. Wohlmuth, M. Meyn, T. Knedilk, A. 
Gutowiski, J. Afeikhena C., Eboue, T. Mama and A. Schoname (eds.) AfricaCommodity Dependence, Resource Course and Export Diversification, African Development Perspectives Yearbook, 273-294, Lit Verlag, Hamburg.

Uzor O.O. (2009) Cluster, Networks and Innovation in Small and Medium Scale Enterprises (SMEs): The Role of Investment in the Development of SMEs in Nigeria, PhD Dissertation, May 2009, Institute for World Economics and International Management University of Bremen, Germany.

Wood A. (200I) 'Value Chains: An Economist's Perspective', IDS Bulletin, special issue 'The Value of Value Chains' 32(3), 4I-45.

World Bank (2002) Results of the Nigeria Firm Survey. Regional Program on Enterprises Development, The World Bank, Washington, DC. 



\title{
5 Mutual productivity spillovers and regional clusters in Eastern Europe
}

\author{
Some empirical evidence
}

Chiara Franco and Kornelia Kozovska

\section{5+I Introduction}

It is widely accepted that foreign direct investment (FDI) is beneficial for the economic development of nations as it introduces fresh capital, new knowledge and the possibility for spillovers (technology, production, knowledge) for the host country. This has led to the wide support and progressive use of policies for the attraction of larger amounts of FDI. At the same time, the empirical literature on the likely impacts of FDI has been largely inconclusive for developing countries and transition economies (for example Aitken and Harrison, 1999; Javorcik, 2004). Some conditions that may affect the process, such as firms' absorptive capacities or the relative technology gap, are traditionally taken into consideration in empirical analyses (see chapter I). However, not enough emphasis has been put on the industrial environment in which local firms operate, in particular, whether the presence and strength of links with other firms may encourage or discourage spillovers. With the increasing importance given to regional clusters and cluster policies as a tool for local and regional development, the relation that these have with FDI is evident. Regional clusters, in fact, present an interesting case for the study of spillovers from foreign firms as their essential characteristics - industrial specialization, higher concentration of specialized labor skills and geographical proximity - could favor the spillover effect due to the potential role they have in attenuating the importance of large productivity gaps or low absorptive capacity.

The literature on FDI spillovers has been traditionally focused on the possibility that the spillover effect runs in only one direction - from the foreign to the local firms. This approach is grounded in the OLI (Ownership, Location, Internalization) paradigm (Dunning, 1977) according to which foreign firms own firm specific assets such as a higher level of technology which is likely to spill over on local firms through various channels (labor mobility, demonstration effect, vertical linkages). The motivations which could drive such behavior have been 
categorized by the International Business literature in market-seeking, resourceseeking and efficiency-seeking FDI (Dunning, 1993). There is a growing strand of literature focused on understanding a further type of motivation, the so-called asset-seeking (for example Fosfuri and Motta, 1999). In this case, the foreign firm is investing abroad in order to have access to resources not available in its home country rather than to exploit an advantage that it already possesses. Only recently some papers, such as Driffield's (2006), have investigated whether this type of motivation may be a source of spillover effect.

Contrary to studies on direct spillover effect, empirical studies on reverse spillovers, or the so-called technology or knowledge-sourcing activities of multinational corporations (MNCs), have been less common, especially so for developing countries and transition economies which should theoretically have less potential for such reverse spillovers. In fact, positive evidence for technology sourcing has been mostly found for developed countries (see De Propis and Driffield, 2006 for a study on the UK) while very few attempts have been carried out for developing countries (see Wei et al, 2008). This is due to the fact that these types of spillovers are considered to be more likely in economies with a higher presence of technologically advanced sectors. However, foreign firms may need to have access not only to higher technology but also to local knowledge. In such a context, regional clusters are interesting cases for the analysis of the presence of reverse spillover as they potentially have a higher concentration of knowledge and expertise and, thus, could be a source of spillovers for the foreign firms as well. This chapter contributes to this discussion by showing some empirical evidence on the potential role regional clusters could have when considering FDI spillovers. By combining information on the existence of regional clusters with firm-level data we have created an original dataset to specifically address the problem of mutual spillovers between foreign-owned and clusters. We test two hypotheses: I) whether the overall effect of direct spillovers is greater for firms in clusters compared to non-clustered firms and 2) whether there is evidence for reverse spillover effects and whether clusters play a part in this.

The choice of studying the interplay between regional clusters and FDI in two new EU-member states - Romania and Poland - is driven by several considerations. In the first place, their experience in transition is an interesting example of economic integration and development. Furthermore, they are of comparable size, and are both new EU member states, implying similar membership benefits and constraints as well as similar potential attractiveness for foreign investors. However, the two countries present two different levels of advancement in economic development as well as different paths of FDI inflows.

The chapter is organized as follows: Section 2 reviews the literature on spillover effects from MNCs to domestic firms. Section 3 gives an overview of the recent literature on reverse spillovers, giving some insight in the possible occur- 
rence of spillover effects from domestic firms to MNCs. Section 4 extends and specifies under which conditions both types of spillover effects are likely to be verified by considering some mediating factors with a focus on the potential contribution of regional clusters. The methodology used for the empirical analysis is described in Section 5. Section 6 discusses the results, while Section 7 offers conclusions and possible policy implications.

\subsection{Foreign direct investment and spillovers: the direct effect}

During the transition period in Eastern Europe FDI has consistently been viewed as a general solution for achieving fast growth with the expectation that it would bring various benefits to the local economies, most importantly fresh capital and technological change. The figures below show the rate of FDI flows into Eastern European countries in the period 1990-2006. Differences in FDI are evident within Central European countries on the forefront, while Bulgaria and Romania have become recipients of higher inflows only in the last couple of years. The second figure isolates the inflows into Poland and Romania where we can note that Poland has been more successful in attracting larger amounts of FDI, while Romania has had a continuous and sharp progress in recent years.

Figure 5.1 FDI inflows into Eastern Europe (1990-2006)

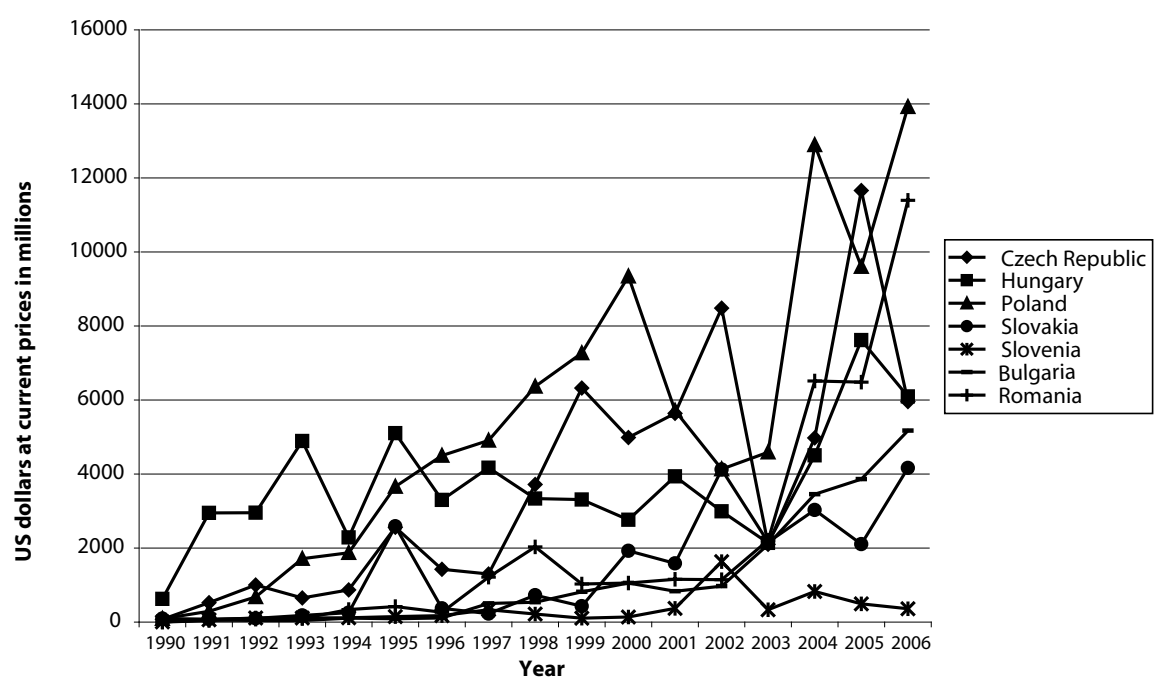


Figure 5.2 FDI inflows into Poland and Romania (1990-2006)

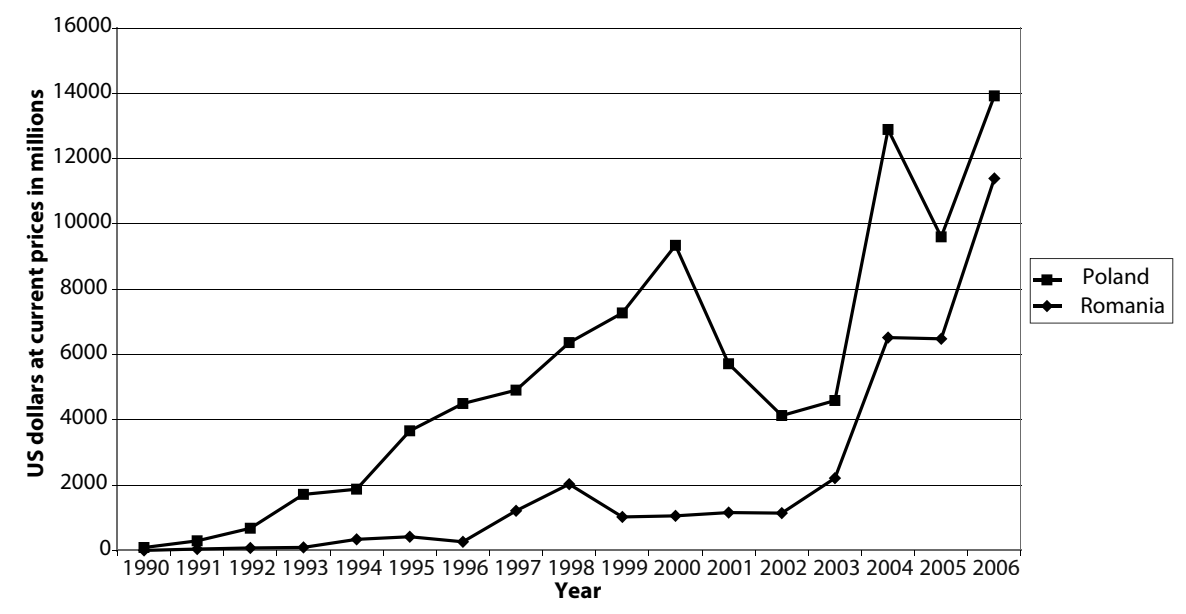

Source: FDI database, UNCTAD

Spillover effects coming from FDI have been extensively studied in the economics and international business literature. The usual definition of spillover given (see chapter I) is that of an externality: it takes place when the presence of foreign firms in the host country affects (both positively and negatively) the productivity of local firms without the possibility for MNCs to fully internalize those benefits. ${ }^{\mathrm{T}}$ The motivations for such effects to occur lie in the OLI paradigm mentioned above. It consists of three categories of factors which simultaneously motivate FDI: I) ownership-specific advantages (O) for firms to operate abroad (for example, intangible assets or property rights), 2) location-specific advantages (such as differences in natural endowments, transport costs, macroeconomic stability, cultural factors, government regulations) to invest in the host rather than the home country (L), and 3) benefits arising from internationalization-specific advantages (I), that is, exploitation of imperfections in external markets. According to this framework, MNCs are essentially asset-exploiting entities in that they own superior assets (technological, managerial and so on) allowing them to successfully invest abroad. At the same time, due to their nature of public goods (at least partially) some part of these superior assets could 'spillover' to local firms.

In our discussion we will call such spillover effects 'direct' because they run in only one direction, that is, from MNCs to domestic firms. However, as summarized by some authors (Görg and Greenaway, 2004; Smeets, 2008), evidence for the actual presence of spillover effects is not particularly clear, neither from a 
theoretical nor an empirical point of view. The estimated final impact on firms' productivity is influenced by various factors: the channels considered, some aspects influencing the behavior of local firms (for example, absorptive capacities, technology gap, geographical proximity), FDI motivations or the behavior of subsidiaries in the host country (see chapter I). Moreover, there are also a number of methodological issues, such as the use of cross-section rather than panel data (Görg and Strobl, 200I) or the way the externality term is specified (Castellani and Zanfei, 2007).

A further aspect is the categorization of spillovers according to the industrial sectors considered - intra-industry spillover effects or horizontal versus interindustry spillover effects or vertical. The search for intra-industry spillovers has often been more difficult in comparison to inter-industry spillovers, irrespective of the country considered. With regards to the former, they can occur through imitation, demonstration, acquisition of human capital from MNCs, or the so-called competition effects (see chapter I). The latter, on the other hand, can occur in the process of MNCs building relationships with local firms which may be their customers or suppliers. The usual motivation for positive vertical effects is that MNCs would prevent the leakage of knowledge to competitive firms in the same industry, while they would be more willing to share their knowledge and raise productivity of those firms which are their buyers or suppliers (see chapter I). For example, Javorcik (2004), analyzing the case of Lithuania, finds a positive vertical spillover effect due to backward linkages. Similar evidence is found by Blalock and Gertler (2004) with respect to Indonesia.

Another issue to be underlined is that according to the OLI paradigm and Dunning's taxonomy (1993) of FDI motivations, the case of direct spillover effect may be justified in the presence of asset-exploiting motivations. In particular, three categories of motivations, which could be potential sources of direct effects, have been identified. The first is relative to the market-seeking motivation, which considers that MNCs invest abroad in order to exploit the possibility of selling their product in a larger market with potential high demand. A second, resource-seeking FDI motivation, is determined by the desire to acquire resources (natural resources, raw materials, or low-cost inputs such as labor) at a lower cost not available in the home country. It involves the relocation of parts of the production chain to the host country. This type of FDI is often driven by the lower cost of labor in the manufacturing sector while availability of natural resources such as oil and gas drives resource-oriented FDI. Further motivation for FDI can be the so-called efficiency-seeking investment characterized by the desire to gain from the common governance of geographically dispersed activities in the presence of economies of scale and scope (Kinoshita and Campos, 
2003). ${ }^{2}$ Bevan and Estrin (2000) find proof for this kind of FDI in the first wave of EU-accession countries as the prospects of EU membership have assisted in the establishment of regional corporate networks. All these factors are also influenced by some more general aspects such as political stability and more concretely the frequency of changes in a country's legal policies and administrative barriers (OECD, 1994), as well as possible FDI incentives such as free economic zones, tax breaks, and so on.

Empirical studies on the direct spillover effect have shown mixed results for the case of transition economies. Djankov and Hoekman (2000) report negative spillovers in the case of the Czech Republic. Similarly, Konings (200I), examining three transition economies, finds negative spillovers for Romania and Bulgaria and no spillovers for Poland. Some authors distinguish between direct effects coming from horizontal and vertical spillovers, but mixed results remain. Some studies find positive results for vertical spillovers (Schoors and van der Tool, 2002; Damijan et al., 2003; Javorcik, 2004; Javorcik and Spatareanu, 2008). Other studies, such as Merlevede and Schoors (2005) for Romania or Yudaeva et al. (2003) for Russia, find no significant results for the vertical spillover effect.

\subsection{Foreign direct investment and spilloversः the reverse effect}

As discussed in the previous section, the usual spillover effect identified by the empirical literature is the direct one. In this framework, flows of knowledge may run in only one direction, that is, from MNCs to local firms. As predicted by the OLI paradigm, FDI will be carried out only if MNCs have ownership advantages to be exploited. However, recent papers are starting to challenge this position, suggesting that local firms may be the source of spillover effect for MNCs as well. This new stream of literature points out to the fact that MNCs do not search for places to invest only in order to exploit the existing assets at their disposal, but also in order to have access or to increase those already possessed at home. In the context of Dunning's taxonomy (1993), we are now considering the case of strategic asset-seeking motivations. This issue has been studied both on a theoretical as well as an empirical level (Neven and Siotis, 1996; Fosfuri and Motta, 1999; Niosi 1999; Le Bas and Sierra, 2002). Empirical papers estimate whether R\&D differentials between countries could stimulate the possibility for technology sourcing, or the so-called reverse spillovers (Kogut and Chang, 1991; Neven and Siotis, 1996). Recent empirical evidence by Driffield and Love (2003) and Driffield (2007) sheds some further light on this issue, even though neither of the papers finds any evidence of spillovers coming from similar asset-seeking 
motivations. Theoretical studies, on the other hand, underline the fact that even a laggard firm may engage in FDI by choosing the location on the basis of the possibility of benefiting from reverse spillovers due to the proximity to local firms. These types of studies are particularly linked to the role of agglomeration economies and spatial proximity. Agglomeration economies refer to the positive externalities and economies of scale associated with spatial concentration of economic activities and co-location of related production facilities (Smith and Florida, 1994). Agglomeration effects due to the presence of specialized service suppliers, skilled labor, location-related reputation effects and the development of clusters, in fact, could have an important role in the location attractiveness for foreign investments (Porter, 1990; Dunning, 1998). New investors tend to concentrate in locations with already established investors which can lead to positive externalities such as knowledge spillovers, specialized labor and intermediate inputs from the surrounding companies. Most of the empirical studies on the issue may be found for developed countries and specifically for the USA (Wheeler and Mody, I992; Head et al., I995) but only very few studies have been done on developing countries and transition economies. Kinoshita and Campos (2003) find that for Eastern European and Baltic countries institutions, agglomeration economies and the abundant natural resources are the main determinants for FDI, overriding the importance of other variables.

In all these cases, contrary to the direct spillover effect, the flows of knowledge between MNCs and local firms (whatever type we want to consider) may also be reversed. For this reason, such processes have been defined as reverse spillover effect. Reverse spillovers are considered more likely where the possibility of spillovers from local firms is greatest and this occurs mostly in cases where the technological level of the host country is higher. It is for this reason that only a few papers analyze the reverse spillover effect in developing countries and transition economies. One of the very few contributions trying to examine this issue is the paper by Wei et al. (2008) considering the case of China. It argues that local knowledge of the context contributes to the productivity increase of MNCs and finds evidence for mutual spillovers (both direct and reverse) between local Chinese manufacturing firms and foreign firms. No studies discussing reverse spillovers have been carried out with respect to transition economies. Transition economies have some peculiar characteristics distinguishing them from both developed and developing countries such as high-skilled labor, relatively developed infrastructure, favorable geographical position and improving institutional structures. These characteristics, in fact, could theoretically contribute to the creation of conditions for reverse spillover effects. 


\subsection{Foreign direct investment and spillovers: the mediating factors}

In the generation of the spillover effects three essential aspects should be taken into consideration. The first one is related to the MNCs which represent the spillover potential as without their investment no spillover effect could take place. The second are the local firms, the so-called receiving side as opposed to the supply side represented by MNCs. The third one consists of the local conditions that may hamper or favor the occurrence of the spillover effect. Examples are the industrial context in which both MNCs and local firms operate or the institutional context (such as for example the level of Intellectual Property Right (IPR) protection).

In considering the spillover effect we should point out that it can be influenced by some characteristics considered as internal (for example, the firm's resources or sector of activity) or external (for example, the local conditions mentioned above) to the firms. Such internal and external factors may be co-evolving and may influence each other reciprocally as well. Moreover, their importance may vary according to the mechanism through which the spillover effect occurs or the sector considered.

In the literature, the most debated internal characteristics influencing the occurrence of spillovers are those relative to the absorptive capacity or the technology gap. They are part of the firm's resources and contribute to differentiate the technological profile of each firm. In the current firm-level literature, absorptive capacity is measured with the firm's $R \& D$ expenses. Technology gap, the other variable used to measure the technological distance between firms, is usually measured with the Total Factor Productivity (TFP) differentials. With regard to the role of absorptive capacity, the evidence is mostly in favor of a positive relationship between its level and the level of spillover (see for example, Girma, 2005), implying that all firms need a minimum amount of absorptive capacity in order to be able to capture some spillover effect. The role played by absorptive capacity may result especially interesting in the case of transition economies because the presence of industries and industrial experience which differentiated transition economies from developing countries was found a misleading factor for higher expectations by some authors (Kornai, 1992; Poznanski, 200I). ${ }^{3}$

With regard to the role played by the technology gap between foreign and domestic firms, on the other hand, the 'technological accumulation' hypothesis of Cantwell (1989) and the 'catching-up' hypothesis of Findlay (1978) present two different positions. In the first case, a smaller gap leads to higher potential for spillovers towards local firms; in the second one, a larger gap is considered to have a higher potential for generating spillover effect (see chapter I).

There is a large debate in the literature on the role of these two factors for mediating the final spillover effect, as well as on the wide variety of ways to measure 
and interpret them theoretically. Other internal characteristics, not directly related to the technological intensity of the firms, are also taken into consideration by some contributions. Barrios et al. (2002), for example, consider how the presence in foreign markets as exporters may be crucial in helping firms reap the benefits of FDI. A similar point of view is taken by Kinoshita (200I), when analyzing the case of the Czech Republic, with evidence of positive spillover effects being more relevant when considering more $\mathrm{R} \& \mathrm{D}$ intensive sectors.

External characteristics or the local conditions in which firms operate can range from a macroperspective on the institutional and legal climate in a country to a more microperspective on the specific firm location conditions, such as spatial proximity to competitors, suppliers or customers. Some recent papers analyze the relationship between the spillover effect and spatial proximity ${ }^{4}$ (Girma and Wakelin, 2007; Resmini and Nicolini, 2007) and find that the spillover effect is positive only when a specification for the location of a firm inside or outside a region is made. This same effect is found, although at the sectoral level, by Driffield and Propis (2006). Our specific contribution is relative to the impact of the presence of regional clusters for spillover effects between foreign and domestic firms.

In this study, we have concentrated on regional clusters as both MNCs activity and absorptive capacity offer interesting implications when examined at the cluster level (Gugler and Brunner, 2007). The attention which clusters have received in recent years through the increased interest in the work of Porter (1998, 2000), as well as the proliferation of cluster initiatives around the world, shows a growing awareness of the localization factor in firm organization. The role of clusters may be worth exploring for many reasons. Regional clusters provide proximity benefits and they assist small and medium enterprises to compete in global markets (Brown and Bell, 200I), thus increasing the productivity and export capacity of local SMEs. As Belussi (2006) points out a growing strand in the international business literature links clusters to MNCs as FDI inflows and subsidiary development can be motivated by the competence and knowledge endowment created in clusters. This could then lead to direct spillovers to the domestic suppliers and other neighboring firms. At the same time however, MNCs in clusters could have the potential of benefiting from reverse spillovers, as even if the technology level of firms in a cluster might be lower, the geographical proximity and the concentration of well-qualified, specialized workers, good knowledge of the market and already established networks could still be factors from which the foreign firm can extract benefits. In fact, potentially due to the characteristics of clusters, firms which are part of a cluster should be able to have higher absorptive capacity than single firms which do not belong to similar agglomeration economies. In fact, a proof of the benefit of clusters for both direct and reverse spillovers can suggest that the usual hypothesis for the technology and R\&D difference as being 
essential for the possibility of benefiting from spillovers could be challenged by the presence of clusters and its importance could become less significant.

It is important to note that MNCs could be localized in proximity to clusters for reasons not necessarily related to the higher technological base, for example low cost labor, specialized labor resources, tax incentives and market presence. They can theoretically find a favorable environment in clusters and could also expect to benefit from reverse spillovers as clusters often possess unique knowledge, expertise and human resources, not necessarily always related to higher technology but for example also to knowledge of the local market. In fact, the main characteristics of clustering could offer benefits to foreign firms which go beyond the pure technological sourcing, and can thus be available also in countries which do not possess superior $R \& D$ endowment. This could add a further motivation for foreign firms to locate themselves in or close to clusters abroad, and especially so in less technologically-advanced or developing economies. In this context, we consider that transition economies present an interesting environment for testing such processes. The link between regional clusters and the absorptive capacity of host firms has not been examined in detail and this chapter tries to shed some light on this interesting and challenging argument, proposing the hypothesis that proximity and networking enhance the positive effects of FDI while, at the same time, creating favorable conditions for reverse spillovers as well. To our knowledge only one paper (Driffield and Propis, 2006), considering the case of the UK, tests the presence of both direct and reverse spillover effect inside and outside clusters. They reach the conclusion that being located inside a cluster makes a difference with regards to both direct and reverse spillover effects.

In this theoretical context, we hypothesize that both direct and reverse spillover effects are likely to be present and positive in regional clusters, compared to non-clustered firms. Furthermore, we believe that contrary to the current evidence in the literature on technology sourcing, reverse spillovers may be found even in the case of low-tech firms located in clusters. MNCs could be able to benefit from knowledge and competence endowments present in clusters which are not necessarily related to superior technology levels. In the following section we test these hypotheses.

\subsection{Empirical analysis}

\subsubsection{Description of datasets}

Our analysis draws on two sets of data: the first allows us to identify clusters in two Eastern European countries (Poland and Romania) using the European Cluster Observatory (ECO) database while the second, the Amadeus database, 
contains firm level data consisting of annual company accounts for all incorporated firms in the manufacturing sectors of the two countries for the time period 2000-2006.

The Cluster Observatory Mapping, made available at the end of 2007, presents a unique comparable database on the location of clusters across Europe and especially for Eastern European countries, where studies on clusters are still in their initial phase. As such, it is one of few sources of systematic data on the type and location of clusters in new EU member states. The Cluster Mapping database 5 is built through the intersection of regions and sectors in Europe, combining the two dimensions of geography and industry by statistically tracing agglomerations of employment in co-located industries, defined as statistical regional clusters, across Europe. Regions are considered at the NUTS 2 level while employment data is considered for the 4-digit industry level. The cluster definition used by ECO is based on the definitions ${ }^{6}$ developed by Porter in his similar analysis of the geographical distribution of economic activity across the USA. ${ }^{7}$ In order to evaluate whether the presence of employment in specific industries belonging to a cluster category in a specific region has a sufficient specialized critical mass to develop the linkages and spillovers which can lead to positive economic impacts, all clusters have been assigned from one (weak clusterization) to three (very strong clusterization) stars. For our sample of countries we have concentrated exclusively on clusters with two or three stars.

The Amadeus database, published by Bureau Van Dijk, includes firm-level accounting data in standardized financial format. Besides financial information, it also contains industry classification, the regional location of each firm and detailed ownership information, including the names and country of origins of all block shareholders which has allowed us to label each firm as domestic or foreign. We have used the accepted definition of foreign-owned firms as firms with a minimum ownership of at least Io\% of the shares by a foreign investor. ${ }^{8}$

For each country we have identified all 2 and 3 star clusters from the European Cluster Observatory database, aggregating them in low-tech and high-tech according to the Organisation for Economic Co-operation and Development (OECD) classification ${ }^{9}$ for a total of 8 I clusters. For Poland we have 25 low-tech and 12 high-tech clusters and for Romania 37 low-tech and 14 high-tech clusters (see annex for an overview). For each cluster, the relative firm level data for the period from 2000 to 2006 , available from the Amadeus database, has been identified, using the relative NACE codes and the respective country's geographical region. In order to be able to do a comparative study between firms in clusters and outside clusters, the information for all firms in the given country which do not belong to the respective clusters and geographical areas but are within the same cluster categories, as defined by the combination of NACE codes, have been 
extracted from Amadeus. The dataset provides information on a total of more than 5,000 firms in Poland and Romania for the period 2000-2006. The use of both databases gives systematic data across countries and allows for a comparative study. Many previous studies on clusters have been mainly done either with especially created ad-hoc datasets or with data available on national/regional level but not easily comparable with other countries. With this current study we attempt to fill in this gap. Table 5.1 gives an overview of our sample:

Table $5.1 \quad$ Data overview

\begin{tabular}{llccc}
\hline & MNCs & Domestic firms & \\
\hline Poland & No firms & No firms & Total \\
& clustered & 384 & 953 & 1337 \\
& non-clustered & 873 & 1901 & 2774 \\
& TOTAL & 1257 & 2854 & 4111 \\
\hline Romania & clustered & 433 & 507 & 940 \\
& non-clustered & 204 & 403 & 607 \\
& TOTAL & 637 & 910 & 1547 \\
\hline
\end{tabular}

Source: Authors' calculations based on data from Amadeus

\subsubsection{Methodology}

The baseline model usually employed to test the spillover effect is the following:

$Y_{\mathrm{ijt}}=a+\beta_{1} X_{j \mathrm{jt}}+\beta_{2} Z_{\mathrm{ijt}}+\varepsilon_{\mathrm{ijt}}$

where $\mathrm{Y}$ is some measure of productivity (for example, total factor productivity or labor productivity), $\mathrm{X}$ is the spillover variable (measured as the share of output of foreign firms on domestic firms at the sectoral ${ }^{10}$ level) and $\mathrm{Z}$ is a set of variables that takes into consideration some factors, the most important ones being the absorptive capacities and the technology gap.

In order to have some insights in the sign of the spillover effect (both direct and reverse), we estimate the benchmark model by only adding a $R \& D$ variable and interacting it with the spillover variable.

$\ln \operatorname{TFP}_{\mathrm{ijt}}=a+\beta_{1} \mathrm{SP}_{\mathrm{jt}}+\beta_{2} \Delta \operatorname{RDint}_{\mathrm{ijt}}+\beta_{3} \mathrm{RD}_{\mathrm{ijt}}{ }^{*}{ } \mathrm{P}_{\mathrm{jt}}+\eta_{\mathrm{t}}+\delta+\varepsilon_{\mathrm{ijt}}$ 
We measure Total Factor Productivity (TFP) as the residuals obtained by first estimating a log-linear transformation of a Cobb-Douglas production function with the Levinsohn and Petrin (2003) estimator.

$\ln Y_{i j t}=a+\beta_{1} \operatorname{lnK}_{i j t}+\beta_{2} \ln M_{i j t}+\beta_{3} \ln L_{i j t}+\varepsilon_{i j t}$

We preferred this estimator as it uses the value of intermediate inputs as a proxy for unobserved productivity shocks, taking for granted that firms will always use a certain positive amount of materials. An alternative, the Olley and Pakes (1996) estimation technique, considers investment as a proxy for the unobserved productivity. A shortcoming of this method, however, is that it assumes that the firm makes a positive investment every year, a condition which is often violated. We measure output $(\mathrm{Y})$ with sales, capital stock $(\mathrm{K})$ is proxied by the declared value of the firm's tangible fixed assets, material inputs $(\mathrm{M})$ are proxied by material costs, and labor $(\mathrm{L})$ is measured by the number of employees. Sales and material costs are deflated by the relative annual two digit NACE production price indices, while capital is deflated by the relative annual country GDP deflator. $R \& D$ expenditure at the firm level is proxied by the declared value of intangible assets. The subscript $\mathrm{i}$ and $\mathrm{t}$ refer to firm and year, respectively, while $\mathrm{j}$ refers to the sector.

We estimate the benchmark model distinguishing between both the location of firms (within or outside clusters) as well as the sector (high-tech versus lowtech). Our expectations for this benchmark estimation is that we find positive results for direct spillovers in both high-tech and low-tech clusters, even in the case where the level of absorptive capacity is not significant. This is motivated by the fact that we expect that flows of knowledge inside the cluster and spillover between and within firms, even though not directly observable, may contribute to enhance the productivity of domestic firms and the way the R\&D is 'used' to take advantage of the spillover effect.

In our analysis we go beyond this benchmark model, adding further control variables and exploring the role of both traditional spillovers as well as $R \& D$ spillovers in the following two models. In the first one we add as a regressor a skills variable for each firm, proxied by the ratio between the cost of employees and the number of employees ${ }^{\mathrm{II}}$, which could be a further element through which the spillover effect may be grasped more easily. In order to measure this effect, we interact the skills variable with the spillover variable.

$$
\begin{aligned}
& \Delta \ln \operatorname{TFP}_{\mathrm{ijt}}=a+\beta_{1} \Delta S P_{\mathrm{jt}}+\beta_{2} \Delta \operatorname{RDint}_{\mathrm{ijt}}+\beta_{3} \Delta \mathrm{RD}_{\mathrm{ijt}} * \mathrm{SP}_{\mathrm{jt}}+\beta_{4} \Delta \text { Skills }_{\mathrm{ijt}}+ \\
& \beta_{5} \Delta \text { Skills }_{\mathrm{ijt}} * \mathrm{SP}_{\mathrm{jt}}+\eta_{\mathrm{t}}+\delta+\varepsilon_{\mathrm{ijt}}
\end{aligned}
$$


In the third model we use a proxy of a firm's activities related to their technological activities and measured as the share of a firm's R\&D activities on the total $\mathrm{R} \& \mathrm{D}$ activities in each NACE 2 digit sector.

In TFP $P_{i j t}=a+\beta_{1}$ RDspjt $+\beta_{2}$ RDintijt $+\beta_{3}$ RDijt $^{*}$ RDspjt $+\beta_{4}$ Skills $_{\text {ijt }}+$

$\beta_{5}$ Skills $_{\mathrm{ijt}}{ }^{*} \mathrm{RDspjt}+\eta_{\mathrm{t}}+\delta+\varepsilon_{\mathrm{ijt}}$

We estimate the model using the residuals of the first step estimation as a dependent variable. We take into consideration time (nt) and sectoral dummies (nt) in order to account for possible business cycle effects and sectoral heterogeneity, respectively. The estimation method chosen at this stage is OLS using first difference in order to eliminate any unobservable firm specific effects. The following table gives an overview of the way all variables have been constructed.

Table 5.2 Description of variables

\begin{tabular}{lll}
\hline Variables & Definition & Source \\
\hline Sales & Log of sales & Amadeus \\
\hline Capital & Log of tangible assets & Amadeus \\
\hline Labor & Log of number of employees & Amadeus \\
\hline Material costs & Log of materials costs & Amadeus \\
\hline R\&D & Intangible assets & Amadeus \\
\hline Horizontal spillover (SP) & $\begin{array}{l}\text { The ratio of the share of foreign/ } \\
\text { domestic firm's output to the total } \\
\text { NACE 2 digit sector output }\end{array}$ & Amadeus \\
\hline Skills & $\begin{array}{l}\text { Proxied by wage intensity, } \\
\text { measured as the ratio of cost of } \\
\text { employees to number of } \\
\text { employees }\end{array}$ & Amadeus \\
\hline R\&D intensity (RDint) & $\begin{array}{l}\text { The ratio between a firm's investment } \\
\text { in R\&D, proxied by the declared value } \\
\text { of intangible assets, and its sales }\end{array}$ & Amadeus \\
& $\begin{array}{l}\text { The ratio of the share of foreign/ } \\
\text { domestic firm's intangible assets } \\
\text { to the total NACE 2 digit sector } \\
\text { intangible assets }\end{array}$ & Amadeus \\
\hline R\&D spillover (RDsp) & & \\
& & \\
& & \\
\hline
\end{tabular}




\subsection{Results}

\subsubsection{Direct spillovers}

When examining the results of the Polish clusters case, we have no statistically significant results for the spillover variable for any of the models, but the sign is consistently negative for both low-tech and high-tech sectors. Similar results are observed in Romania as well. This suggests that the productivity of domestic firms located within clusters is negatively influenced by MNCs. When looking at non-cluster firms, we have consistently positive and significant results in Poland, that is, MNCs are a source of positive productivity spillovers for domestic firms. Also in this case, the technology intensity of the sector is irrelevant for the sign and significance of the results. For the Romanian case, results are not significant statistically but they suggest that domestic low-tech firms benefit from positive productivity spillovers while domestic firms in high-tech sectors are influenced negatively by the presence of MNCs.

\subsubsection{Reverse spillovers}

With regard to reverse spillovers, for firms located within clusters in both Poland and Romania, our results are in most cases not statistically significant but the sign of the coefficients shows a clear pattern of a positive effect on foreign firms' productivity (with the exception of the high-tech benchmark model in Poland and the low-tech benchmark model in Romania). For firms located outside the cluster, the evidence from Poland is generally not statistically significant, but with a consistent negative sign. Similarly, in Romania negative and statistical significant results are present for high-tech sectors while positive, but not significant, for low-tech sectors.

\subsubsection{The role of research and development}

Interestingly, we find consistent negative and significant results for the role of $\mathrm{R} \& \mathrm{D}$ intensity on firms productivity, across sectors and independent of the location within or outside clusters. Our results show that a higher ratio of intangible assets to sales, used as a proxy for firm's $R \& D$, leads to lower productivity.

Looking into the R\&D spillover variable, the negative impact on domestic firms productivity persists in Poland even though not statistically significant for firms located in and outside of clusters. Romania shows mixed results, positive but not significant for high-tech domestic firms (negative for non-cluster firms) and negative for low-tech domestic firms (positive for non-cluster firms). For foreign firms, on the other hand, positive but not statistically significant impact is observed for both cluster and non-cluster firms. In Romania, positive influence 
on foreign firms' productivity is present for firms in clusters while outside of clusters, this is so only for high-tech sectors.

The R\&D spillover variable, in its interactions with a firm's own R\&D, generally affects negatively the productivity of firms. Although the coefficients are in most cases not statistically significant, the negative sign of almost all relative coefficients gives proof for a consistent trend. We can interpret these results as either the lack of ability of both domestic and foreign firms to internalize possible externalities caused by higher levels of $\mathrm{R} \& \mathrm{D}$ investment in the given sectors, or of the very insignificant role $\mathrm{R} \& \mathrm{D}$ spillovers have on firms' productivity. On the other hand, firms not located in regional clusters show some evidence of a positive role of R\&D, especially in the case of reverse spillovers, both for high-and low-tech sectors. This suggests that foreign firms with higher levels of $R \& D$ are influenced positively by R\&D spillovers and skills and firm level R\&D play a positive role.

\subsubsection{The role of skills}

When testing for the role of skills in explaining the productivity of firms, we find that higher wage intensity, taken as a proxy of skills, influences positively the productivity of firms, both in high-and low-tech sectors as well as in clusters and outside clusters. However, the role of skills for the ability of absorbing spillovers is much less clear. We see evidence that higher skill intensity in domestic firms, when interacted with the spillover variable, generally affects positively firms in Poland. However, the results are not statistically significant. In Romania, on the other hand, higher skills affect negatively the spillover effect in high-tech firms located in clusters. With regard to the reverse spillovers, we observe negative impact for high-tech firms in Poland, that is, higher skill intensity does not increase the possibility of benefiting for spillover, but, on the contrary, affects negatively the productivity of foreign firms. In Romania the evidence is contrary and higher skills contribute to positive spillovers. No particular difference is noted for firms located within and outside regional clusters. This confirms theoretical affirmations that domestic firms with higher skill levels are more capable of benefiting from direct spillovers and increasing their productivity. High-tech sectors, as shown by our evidence, are especially sensitive to such dynamics.

\section{$5+7$ Conclusion}

According to the literature on spillovers, the spillover effect should predominantly run in one direction, from foreign to domestic firms and this is the standard model tested in empirical specifications. Usually, the model is made more com- 
plex by taking into consideration the fact that there may be some conditionalities, such as absorptive capacities or the level of the technology gap, that may favor the process. However, the mixed results found in the literature suggest that some factors are not properly taken into consideration. First of all, the absorptive capacity may be enhanced by the fact that firms are clustered together. This is why we have investigated whether the spillover effect could be greater by using a dataset properly divided according to location within or outside regional clusters. Moreover, due to the higher attractiveness of Eastern European countries for FDI, we tested whether a reverse spillover hypothesis could be true in this case. Previous studies examining reverse spillover have been done in most cases for developed countries, but not for transition economies.

We go back to our initial hypotheses on the overall effect of direct spillovers for firms located in regional clusters compared to non-clustered firms and on the presence of reverse spillover effect and any potential role for clusters. With regard to our hypothesis on the presence of direct spillovers in cluster firms, our evidence shows that domestic firms located within clusters do not benefit from positive spillovers. Contrary to expectations, domestic firms not located within clusters do benefit from positive direct spillovers. In Poland the technological intensity of the sector does not make any difference while in Romania the productivity of domestic firms located in high-tech sectors is affected negatively by MNCs, suggesting that possibly the technology gap is too large for any positive productivity spillovers. Looking into the reverse effect, even though not statistically significant in many cases, our results suggest that foreign firms benefit from being located within clusters while in contrast their productivity is influenced negatively if located outside.

Our findings could have important implications for FDI and cluster policies. In fact, where foreign firms are located in clusters, it is likely that their productivity is greater and thus, they are likely to be more willing to collaborate with other domestic firms and organizations to support the cluster as they could benefit from such collaboration themselves. This suggests that clusters could be considered attractive for MNCs as foreign firms could be able to benefit from cluster-specific assets and as such the cluster could become a motivation for asset-seeking MNCs. In fact, our results suggest that it is MNCs which could actually benefit more from locating within regional clusters in terms of productivity gains. On the contrary, domestic firms experience negative spillovers when located in clusters.

The potential role of regional clusters as a mediating factor, in general, finds mixed proof in our results. A possible explanation is the lack of tradition in networking and creating linkages among firms in transition economies due to the previously centrally planned system. This could lead to domestic firms being part 
of regional clusters which are still not able to effectively create linkages and benefit from the various externalities which are present in clusters in order to transform this in a positive effect on their productivity. The evidence from Poland and Romania shows that the level of R\&D does not seem to be essential for the ability of benefiting from spillovers, while a much more important role is played by skills.

Cluster and FDI policies should in any case be perceived as mutually reinforcing in their design and allow exploiting and creating synergies between the ownership advantages of the MNCs and the competitive advantage of the location. However, cluster policies which extensively encourage FDI, motivated by perceiving MNCs as a source of significant spillovers, should take into consideration that there is no robust evidence showing that MNCs indeed are a source of direct spillovers for domestic firms.

\section{Notes}

I In this chapter, we consider spillover effects as those coming from both knowledge and pecuniary externalities.

2 We should note that in most empirical studies the definition used for efficiency-seeking motivation mainly overlaps with that of resource-seeking.

3 In fact, the socialist system was structured in such a manner that growth was a result of central resource transfers and not of entrepreneurial efforts. This led to almost absent local innovation and technological change, any technological innovation for most of the socialist period arrived generally via the acquisition of machinery. As there was no price premium and no free entry into the economy, underinvestment in new industries and services was a common phenomenon. Some authors question the advantages which transition countries were supposed to have in comparison to other developing countries as most of these advantages, inherited firm-specific assets, inherited accumulated human capital, have proven unsubstantial. Konings (200I) and Jensen (2004) find that transition countries experience similar difficulties in successfully benefiting from FDI.

4 It should be pointed out, however, that the literature on localized knowledge spillover is more extensive than the literature related only to the spillover effect coming from FDI.

5 The European Cluster Observatory database can be found under Cluster mapping on the website of the project www.clusterobservatory.eu. The project offers a unique compilation of data on geographical patterns of specialization across cluster categories, national and regional portfolios of clusters, cluster organizations, and national and regional policies and programs related to innovation and clusters.

6 Porter identifies geographic distribution of employment, relates it to the appropriate definition of geographic regions (NUTS 2 level for the EU), obtaining employment data at the highest available level of industry granularity (mostly NACE 4-digit level).

7 It should be noted that cluster definitions do not always reflect the true underlying linkages between industries in the new member states as trade barriers and other political interferences could have significantly influenced current location patterns. 
This is the standard definition provided by the Organisation for Economic Co-operation and Development (OECD) and the International Monetary Fund (IMF).

9 See Hatzichronoglou (I997).

Io The term 'sector' is intended as the aggregation of all high-tech or low-tech sectors, respectively, in the given country and according to the division cluster/non cluster.

I I A better proxy for skills would be a variable which directly measures the skill training intensity (that is, the expenditure devoted to training) or the skills intensity of employment (that is the number of employees directly involved in production, as a proportion of total employment). Such measures are used, for example, by Marin and Bell (2006) and Girma et al. (2009). However, due to data constraints we only employ a measure that accounts for wage intensity calculated as wage per employee expenditure. Hence, results involving this variable need to be interpreted with caution.

\section{List of references}

Aitken B. and A. Harrison (1999) 'Do Domestic Firms Benefit from Direct Foreign Investment? Evidence from Venezuela', American Economic Review 89(3), 605-618.

Barrios S. and E. Strobl (2002) 'Foreign Direct Investment and Productivity Spillovers: Evidence from the Spanish Experience', Weltwirtschaftliches Archiv I38(3), 459-48I.

Belussi F. (2006) 'In Search of a Theory of Spatial Clustering, Agglomeration vs. Active Clustering', in B.T. Asheim, P. Cooke and R. Martin (eds.) Clusters in Regional Development, Critical Reflections and Explorations, Routledge, London.

Bevan A. and S. Estrin (2000) 'The Determinants of Foreign Direct Investment in Transition Economies', William Davidson Institute Working Paper 342, University of Michigan, Ann Arbor.

Blalock G. and P. Gertler (2004) 'Learning from Exporting Revisited in a less Developed Setting', Journal of Development Economics 75(2), 397-416.

Brown P. and J. Bell (200I) 'Industrial Clusters and Small Firm Internationalisation', in J. Taggart, S. Young and N. Hood (eds.) The Multinational in the Millennium, Companies and Countries, Changes and Choices, Palgrave, Basingstoke.

Cantwell J.A. (1989) Technological Innovation and Multinational Corporations, Basil Blackwell, Oxford.

Castellani D. and A. Zanfei (2007)'Multinational Companies and Productivity Spillovers: Is There a Specification Error?', Applied Economic Letters I4, I047-I05I.

Damijan J., M. Knell, B. Majcen, and M. Rojec (2003) 'Technology Transfer through FDI in Top-Io Transition Countries: How Important Are Direct Effects, Horizontal and Vertical Spillovers?' William Davidson Working Paper 549, University of Michigan, Ann Arbor. 
De Propis L. and N. Driffield (2006)'The Importance of Clusters for Spillovers from Foreign Direct Investment and Technology Sourcing', Cambridge Journal of Economics 30, 277-29I.

Djankov S. and B. Hoekman (2000) 'Foreign Investment and Productivity Growth in Czech Enterprises', World Bank Economic Review I4(I), 49-64.

Driffield N. (2006) 'On the Search for Spillovers from Foreign Direct Investment with Spatial Dependency', Regional Studies 40(I), I07-II9.

Driffield N. and J.H. Love (2003) 'Foreign Direct Investment, Technology Sourcing and Reverse Spillovers', Manchester School 71/6, 659-672.

Driffield N. and J.H. Love (2007) 'Linking FDI Motivation and Host Economy Productivity Effects, Conceptual and Empirical Analysis', Journal of International Business Studies 38(3), 460-473.

Dunning J.H. (1977) 'Trade, Location of Economy Activity and MNEs. A Search for an Eclectic Approach', in P. Ohlin, O. Hesselborn and P.S. Wijkmaneds (eds.) The International Allocation of Economic Activity, Macmillan, London.

Dunning J.H. (1993) Multinational Enterprises and the Global Economy, Wokingham, Addison-Wesley, UK.

Dunning J.H. (1998) 'Location and the Multinational Enterprises: A Neglected Factor?' Journal of International Business Studies 29, 45-66.

Findlay R. (1978) 'Relative Backwardness, Direct Foreign Investment and the Transfer of Technology: A Simple Dynamic Model', Quarterly Journal of Economics $92(\mathrm{I}), \mathrm{I}-\mathrm{I} 6$.

Fosfuri A. and M. Motta (1999) 'Multinational Without Advantages', Scandinavian Journal of Economics IOI(4), 617-630.

Girma S., Y. Gong and H. Görg (2009) 'What Determines Innovation Activity in Chinese State-owned Enterprises? The Role of Foreign Direct Investment', World Development 37(4), 866-873.

Girma S. and K. Wakelin (2007) 'Local Productivity Spillovers from Foreign Direct Investment in the U.K. Electronics Industry', Regional Science and Urban Economics 37(3), 399-412.

Görg H. and E. Strobl (200I) 'Multinational Companies and Productivity Spillovers: A Meta-Analysis', Economic Journal (III), 723-739.

Görg H. and D. Greenaway (2004) 'Much Ado about Nothing? Do Domestic Firms Really Benefit from Foreign Direct Investment?', World Bank Research Observer I9(2),I7I-I97.

Gugler P. and S. Brunner (2007) 'FDI Effects on National Competitiveness: A Cluster Approach', International Advances in Economic Research 13, 268-284.

Habuda J. and A. Szalavetz (2000) Technology Transfer, Innovation and Modernisation. The Example of German-owned Hungarian Engineering Firms, Weltforum Verlag. 
Hatzichronoglou T. (1997) 'Revision of the High-Technology Sector and Product Classification', STI Working Paper 1997/2, OECD, Paris.

Head K., J. Ries and D. Swenson (1995) 'Agglomeration Benefits and Location Choice. Evidence from Japanese Manufacturing Investments in the United States', Journal of International Economics 38(3-4), 223-247.

Javorcik B.S. and M. Spatareanu (2008) 'To Share or Not to Share:, Does Local Participation Matter for Spillovers from Foreign Direct Investment?', Journal of Development Economics 85, 194-217.

Javorcik B.S. (2004) 'Does Foreign Direct Investment Increase the Productivity of Domestic Firms? In Search of Spillovers Through Backward Linkages', American Economic Review 94(3), 605-627.

Jensen C. (2004) 'Localized Spillovers in the Polish Food Industry: The Role of FDI in the Development Process', Regional Studies 38, 535-550.

Kinoshita Y. (200I) 'R\&D and Technology Spillovers through FDI: Innovation and Absorptive Capacity', Centre for Economic Policy Research (CEPR) Discussion Paper 2775, London.

Kinoshita Y. and N. Campos (2003) 'Why Does FDI Go Where it Goes? New Evidence from the Transition Economies', William Davidson Institute Working Paper 573, University of Michigan, Ann Arbor.

Kogut B. and S.J. Chang (199I) 'Technological Capabilities and Japanese Foreign Direct Investment in the United States', Review of Economics and Statistics 73(3), 40I-413.

Konings J. (200I) 'The Effect of Direct Foreign Investment on Domestic Firms: Evidence from Firm Level Panel Data in Emerging Economies, Economics of Transition 9(3), 619-633.

Kornai J. (1992) 'The Post-Socialist Transition and the State, Reflections in the Light of Hungarian Fiscal Problems', American Economic Review 82(2), I-2I.

Lankes H. and A. Venables (1996)'Foreign Direct Investment in Economic Transition. The Changing Pattern of Investments', The Economics of Transition 4(2), 331-347.

Levinsohn J. and A. Petrin (2003) 'Estimating Production Functions Using Inputs to Control for Unobservables', Review of Economic Studies 70, 317-334.

Le Bas C. and C. Sierra (2002) 'Location versus Home Country Advantages in R\&D Activities, Some Further Results on Multinationals' Location Strategies', Research Policy 3I(4), 589-609.

Marin A. and M. Bell (2006) 'Technology Spillovers from Foreign Direct Investment: An Exploration of the Active Role of MNC Subsidiaries in the Case of Argentina in the I990s', Journal of Development Studies 42(4), 678-697.

Merlevede B. and K. Schoors (2005) 'Conditional Spillovers from FDI Within and Between Sectors, Evidence from Romania', Department of Economics and CERISE, University of Ghent. 
Neven D. and G. Siotis (1996) 'Technology Sourcing and FDI in the EC: An Empirical Evaluation', International Journal of Industrial Organization I4(5), 543-560.

Nicolini M. and L. Resmini (2007) 'Productivity Spillovers and Multinational Enterprises: In Search of a Spatial Dimension', DYNREG Working Paper ı,, Economic and Social Research Institute, Dublin.

Niosi J. (1999) 'Fourth-Generation R\&D: From Linear Models to Flexible Innovation', Journal of Business Research 45(2), III-II7.

OECD (1994) Assessing Investment Opportunities in Economies in Transition, OECD, Paris.

Porter M. (1998) 'Clusters and the New Economics of Competition', Harvard Business Review 76(6), 77-90.

Porter M. (2000) 'Location, Competition, and Economic Development: Local Clusters in Global Economy', Economic Development Quarterly I4(I), 15-34.

Poznanski K. (200I) 'Building Capitalism with the Communist Tools. Defective Transition in Eastern Europe', East European Politics and Societies 15(2), 317352.

Resmini L. (2000) 'The Determinants of Foreign Direct Investment in the CEECs. New Evidence from Sectoral Patterns', Economics of Transition 8(3), 665-689.

Schoors K. and B. van der Tol (2002) 'Foreign Direct Investment Spillovers within and between Sectors. Evidence from Hungarian Data', Working Paper 157, Department of Economics, Ghent University, Belgium.

Siotis G. (1999) 'Foreign Direct Investment Strategies and Firms' Capabilities', Journal of Economics and Management Strategy 8(2), 251-270.

Smeets R. (2008) 'Collecting the Pieces of the FDI Knowledge Spillovers Puzzle', The World Bank Research Observer 23(2), 107-138.

Smith D. and R. Florida (1994) 'Agglomeration and Industrial Location: An Econometric Analysis of Japanese-Affiliated Manufacturing Establishments in Automotive-Related Industries', Journal of Urban Economies 36, 23-4I.

Wei Y., X. Liu and C. Wang (2008) 'Mutual Productivity Spillovers between Foreign and Local Firms in China', Cambridge Journal of Economics 32(4), 609-63I.

Wheelern D. And C. Mody A. (1992) 'International Investment Location Decisions. The Case of US Firms', Journal of International Economics 33, 57-76.

Woodward D., R. Rolfe, P. Guimaraes and T. Doupnik (1997) 'Taxation and the Location of Foreign Direct Investment in Central Europe', University of Southern Carolina Working Paper, University of South Carolina.

Yudaeva K., K. Kozlov, N. Melentieva and N. Ponomareva (2003) ‘Does Foreign Ownership Matter? The Russian Experience', Economics of Transition II(3), 383-410. 


\section{Annex: Tables}

Table 5.3 Descriptive statistics - Poland

\begin{tabular}{|c|c|c|c|c|c|c|c|c|}
\hline & & & Capital & Sales & $\begin{array}{c}\text { Material } \\
\text { costs }\end{array}$ & $\begin{array}{c}\text { Emplo- } \\
\text { yees }\end{array}$ & Skills & RDint \\
\hline \multirow{4}{*}{ 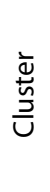 } & Domestic & mean & 53,70 & 225,07 & 113,64 & 322,04 & 7,01 & 0,01 \\
\hline & firms & std.dev & 148,04 & 743,62 & 191,03 & 325,20 & 16,65 & 0,05 \\
\hline & MNCs & mean & 156,11 & 511,21 & 267,77 & 429,12 & 9,36 & 0,02 \\
\hline & & std.dev & 733,82 & 1237,51 & 746,28 & 746,60 & 5,53 & 0,28 \\
\hline \multirow{4}{*}{ 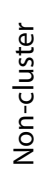 } & Domestic & mean & 51,94 & 187,77 & 80,50 & 319,89 & 7,44 & 0,02 \\
\hline & firms & std.dev & 161,25 & 687,56 & 244,34 & 357,70 & 13,02 & 0,28 \\
\hline & MNCs & mean & 127,69 & 467,67 & 285,39 & 418,37 & 9,68 & 0,02 \\
\hline & & std.dev & 331,15 & 1422,04 & 927,76 & 605,22 & 9,26 & 0,26 \\
\hline
\end{tabular}

Table 5.4 Descriptive statistics - Romania

\begin{tabular}{|c|c|c|c|c|c|c|c|c|}
\hline & & & Capital & Sales & $\begin{array}{c}\text { Material } \\
\text { costs }\end{array}$ & $\begin{array}{c}\text { Emplo- } \\
\text { yees }\end{array}$ & Skills & RDint \\
\hline \multirow{4}{*}{ 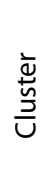 } & Domestic & mean & 12,33 & 26,69 & 16,02 & 479,71 & 2,57 & 0,01 \\
\hline & firms & std.dev & 50,49 & 82,87 & 65,09 & 641,47 & 3,14 & 0,11 \\
\hline & MNCs & mean & 29,95 & 63,62 & 40,42 & 467,58 & 4,61 & 0,10 \\
\hline & & std.dev & 243,77 & 412,14 & 295,03 & 1287,15 & 51,79 & 3,99 \\
\hline \multirow{4}{*}{$\begin{array}{l}\bar{\Phi} \\
\bar{U} \\
\bar{U} \\
\frac{1}{L} \\
\frac{1}{Z}\end{array}$} & Domestic & mean & 16,72 & 31,87 & 20,55 & 411,82 & 2,97 & 0,03 \\
\hline & firms & std.dev & 43,87 & 58,97 & 44,66 & 620,70 & 2,26 & 0,38 \\
\hline & MNCs & mean & 49,80 & 107,86 & 76,29 & 558,78 & 5,18 & 0,14 \\
\hline & & std.dev & 232,97 & 247,72 & 201,68 & 1020,83 & 13,26 & 1,84 \\
\hline
\end{tabular}




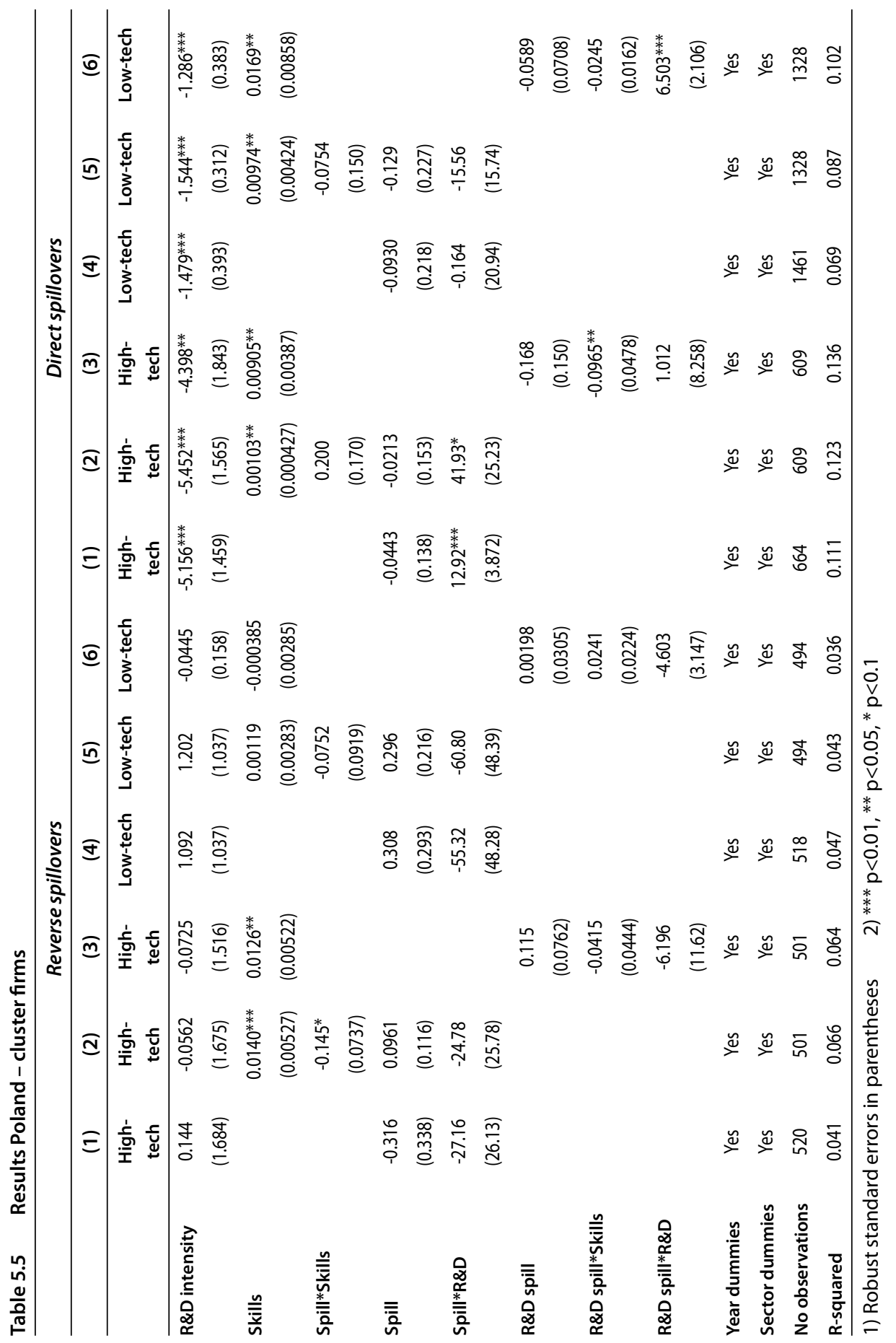




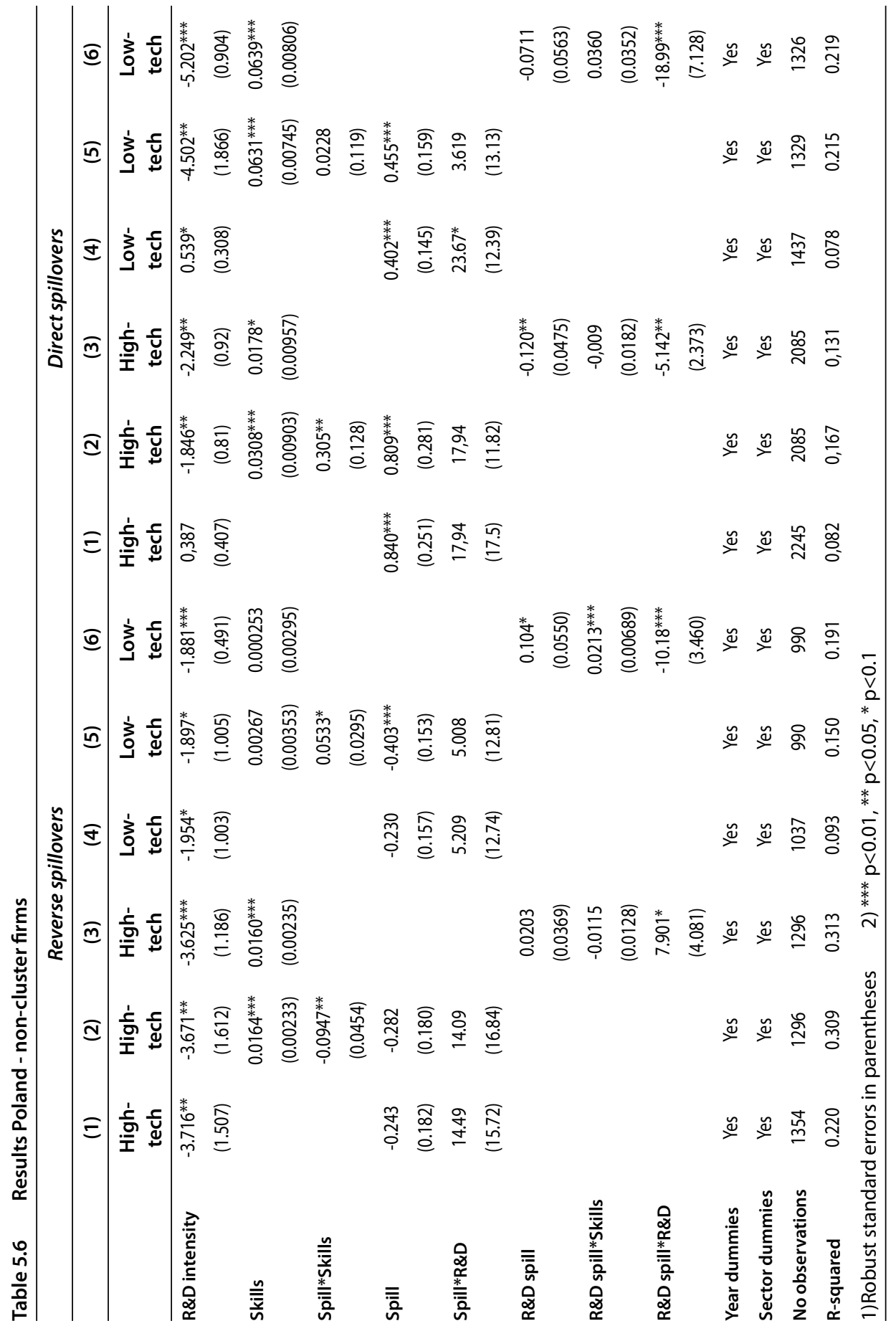




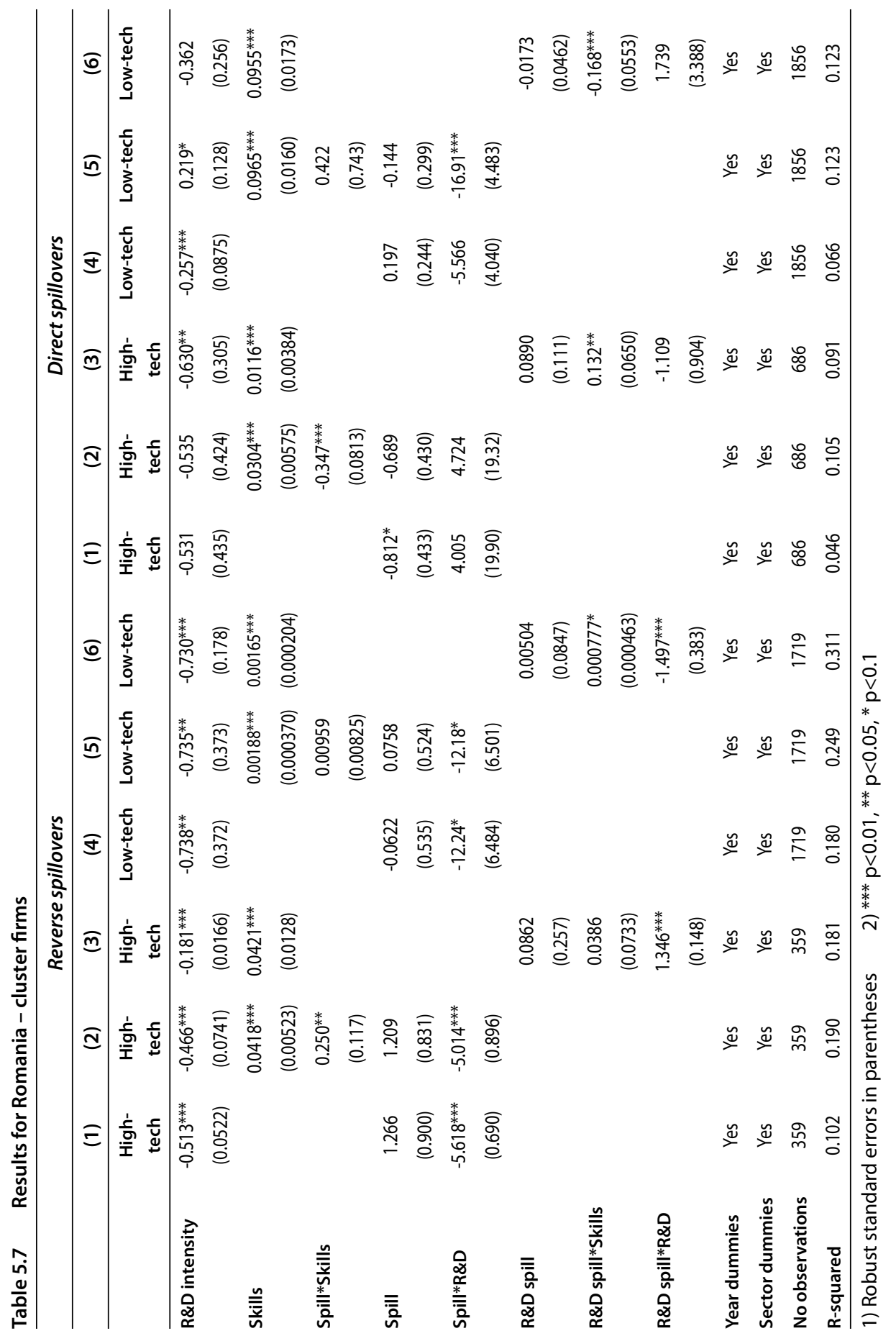




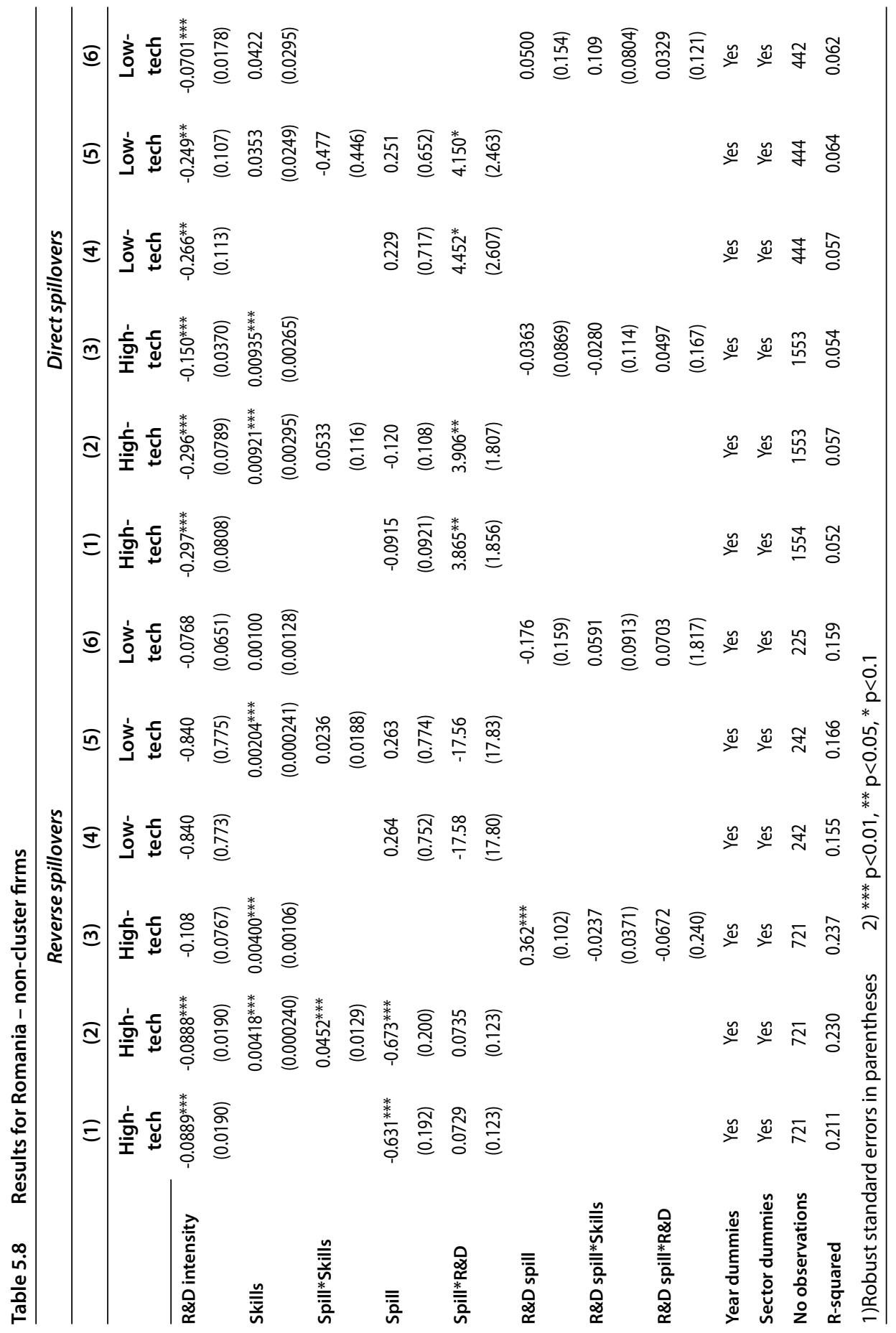


Table 5.9 Clusters in Romania

\begin{tabular}{|c|c|c|}
\hline Region & Cluster category & High-tech/Low-tech sector \\
\hline Vest & Apparel & Low-tech \\
\hline Sud - Muntenia & Apparel & Low-tech \\
\hline Nord-Est & Apparel & Low-tech \\
\hline Sud-Est & Apparel & Low-tech \\
\hline Nord-Vest & Apparel & Low-tech \\
\hline Centru & Apparel & Low-tech \\
\hline Bucuresti - Ilfov & Apparel & Low-tech \\
\hline Sud-Vest Oltenia & Apparel & Low-tech \\
\hline Sud - Muntenia & Building fixtures & Low-tech \\
\hline Nord-Est & Building fixtures & Low-tech \\
\hline Nord-Vest & Building fixtures & Low-tech \\
\hline Centru & Building fixtures & Low-tech \\
\hline Vest & Building fixtures & Low-tech \\
\hline Vest & Footwear & Low-tech \\
\hline Nord-Vest & Footwear & Low-tech \\
\hline Bucuresti - Ilfov & Footwear & Low-tech \\
\hline Centru & Footwear & Low-tech \\
\hline Nord-Vest & Forest & Low-tech \\
\hline Nord-Vest & Furniture & Low-tech \\
\hline Centru & Furniture & Low-tech \\
\hline Nord-Est & Furniture & Low-tech \\
\hline Vest & Leather & Low-tech \\
\hline Bucuresti - Ilfov & Leather & Low-tech \\
\hline Centru & Leather & Low-tech \\
\hline Nord-Est & Leather & Low-tech \\
\hline Sud - Muntenia & Oil and gas & Low-tech \\
\hline Sud-Vest Oltenia & Oil and gas & Low-tech \\
\hline Sud-Est & Oil and gas & Low-tech \\
\hline Nord-Est & Oil and gas & Low-tech \\
\hline Centru & Oil and gas & Low-tech \\
\hline Sud - Muntenia & Textiles & Low-tech \\
\hline Centru & Textiles & Low-tech \\
\hline Nord-Est & Textiles & Low-tech \\
\hline Nord-Vest & Textiles & Low-tech \\
\hline Vest & Textiles & Low-tech \\
\hline Bucuresti - Ilfov & Textiles & Low-tech \\
\hline Sud-Est & Textiles & Low-tech \\
\hline Sud - Muntenia & Automotive & High-tech \\
\hline Sud-Vest Oltenia & Power & High-tech \\
\hline Centru & Power & High-tech \\
\hline Sud - Muntenia & Power & High-tech \\
\hline Sud-Vest Oltenia & Heavy machinery & High-tech \\
\hline Vest & Heavy machinery & High-tech \\
\hline Centru & Heavy machinery & High-tech \\
\hline Sud - Muntenia & Heavy machinery & High-tech \\
\hline Sud-Est & Metal & High-tech \\
\hline Sud - Muntenia & Metal & High-tech \\
\hline Bucuresti - Ilfov & Aerospace & High-tech \\
\hline Sud-Vest Oltenia & Chemical & High-tech \\
\hline Vest & Communications & High-tech \\
\hline Vest & Constr. materials & High-tech \\
\hline
\end{tabular}


Table 5.10 Clusters in Poland

\begin{tabular}{lll}
\hline Region & Clustercategory & High-tech/Low-tech sector \\
\hline Lodzkie & Apparel & Low-tech \\
Wielkopolskie & Apparel & Low-tech \\
Kujawsko-Pomorskie & Apparel & Low-tech \\
Lubelskie & Apparel & Low-tech \\
Warminsko-Mazurskie & Apparel & Low-tech \\
Slaskie & Building fixtures & Low-tech \\
Warminsko-Mazurskie & Building fixtures & Low-tech \\
Swietokrzyskie & Building fixtures & Low-tech \\
Lodzkie & Textiles & Low-tech \\
Wielkopolskie & Lighting & Low-tech \\
Wielkopolskie & Food & Low-tech \\
Mazowieckie & Food & Low-tech \\
Slaskie & Food & Low-tech \\
Lodzkie & Food & Low-tech \\
Kujawsko-Pomorskie & Food & Low-tech \\
Podkarpackie & Food & Low-tech \\
Lubelskie & Food & Low-tech \\
Warminsko-Mazurskie & Food & Low-tech \\
Podlaskie & Food & Low-tech \\
Lubuskie & Food & Low-tech \\
Opolskie & Food & Low-tech \\
Wielkopolskie & Furniture & Low-tech \\
Warminsko-Mazurskie & Furniture & Low-tech \\
Kujawsko-Pomorskie & Furniture & Low-tech \\
Lubuskie & Furniture & Low-tech \\
Slaskie & Heavy machinery & High-tech \\
Dolnoslaskie & Heavy machinery & High-tech \\
Wielkopolskie & Heavy machinery & High-tech \\
Podkarpackie & Aerospace & High-tech \\
Lodzkie & Constr. materials & High-tech \\
Slaskie & Construction & High-tech \\
Opolskie & Construction & High-tech \\
Slaskie & Metal & High-tech \\
Slaskie & Production tech. & High-tech \\
Opolskie & Production tech. & High-tech \\
Podkarpackie & Automotive & High-tech \\
Mazowieckie & Biopharma & High-tech \\
\hline & & \\
& & \\
\hline & &
\end{tabular}





\section{Part III}

Policies to Promote SPILlOVERS

AND LINKAGES 



\title{
6 Scope and effectiveness of foreign direct investment policies in transition economies*
}

\author{
Črt Kostevc ${ }^{\star \star}$, Tjaša Redek ${ }^{\star \star \star}$ and Matija Rojec ${ }^{\star \star \star \star}$
}

\section{I Introduction}

Basic questions related to government actions in attracting foreign direct investment (FDI) in general, and specifically actions related to spillover effects and knowledge transfer via FDI are: Is there a rationale and scope for specific FDIrelated government intervention and, if yes, what should it look like and how efficient it is? We will tackle these issues by analyzing the existing theoretical considerations and empirical evidence on the subject, as well as experiences of selected transition countries.

In theory, the rationale for investment incentives seems to be quite limited; economics of investment incentives are largely based on the possibility of (positive) spillovers (knowledge and technology) from foreign-owned subsidiaries to domestic firms. But, in practice, governments have created numerous policy measures to attract foreign capital and reap the benefits of both their direct impact on employment, income and growth, as well as benefits from spillover effects. Although specific foreign-investor-friendly policies cannot compensate for the lack of 'basic attractiveness' of a country or for an inadequate and/or business unfriendly legal, institutional and policy framework, research does show a positive link between FDI incentives and the amount of foreign capital attracted to a country, as well as the subsequent behavior of foreign investors. FDI incentives become especially important in the case of competition between similar potential investment locations. Data show that competition for FDI has increased strongly in the past two decades and so did the provision of fiscal and financial incentives for foreign investors.

The focus of the chapter is on analyzing the investment incentives policies in transition countries from the perspective of recent trends in incentives policies and their effectiveness in attracting more and better FDI. Existing studies on incentive policies of transition economies will be reviewed and their effective- 
ness from the point of view of policy objectives, type and size of incentives, and delivery practice will be studied. Investment incentives policies of the following countries will be analyzed in a comparative perspective: Croatia, Czech Republic, Estonia, Hungary, Romania, Slovak Republic, and Slovenia. The focus will be on the behavioral incentives, targeting specific goals, like export propensity, transfer of technology, R\&D activity, engaging of local suppliers and so on.

The structure of the chapter is as follows. First, the scope of the FDI regime and policy in determining a country's attractiveness as investment location is analyzed. Second, we look at the economics of investment incentives, and, third, we analyze the main issues and trends in incentives policies. Then, the focus turns to transition economies. Section four overviews the existing studies on the effectiveness of incentives policies in transition countries, and in section five we look at incentives policies of selected transition countries. The chapter concludes with some policy suggestions.

\subsection{The scope of foreign direct investment regime and policy in determining a country's attractiveness as investment location}

Key elements of a country's attractiveness as investment location are its basic structural characteristics, that is to say market characteristics (market size and per capita income, market growth, access to regional and global markets), and availability/quality/costs of factors of production (labor, raw materials and other inputs, technological, innovatory and other created assets, physical infrastructure). These are followed by general regulatory and policy frameworks, which define an investment climate in its broadest sense. They include elements such as economic, political and social stability, privatization policy, trade regime and policy, tax rates and tax structure, labor market and product markets regulations and policies, and so forth. Only if these basic preconditions are in place, can specific FDI regimes and policies become relevant for attracting foreign investors (see for instance, Dunning, 1993; UNCTAD, 1998; Creditanstalt, 1992; A.T. Kearney, I998; Meyer, I998).

OECD intercountry variations in inward FDI stocks show that slightly over one half of the variation is explained by countries' structural characteristics and slightly less than half by policy factors. The most important among the policy factors are labor market policies, explaining more than $25 \%$ of the intercountry variations, followed by other border barriers, FDI restrictions and product market policies. The latter three combined account for approximately $20 \%$ of the variations in inward FDI stocks (OECD, 2003). Although the investment climate and FDI policy factors are in a certain sense of secondary importance, 
they undoubtedly have a crucial impact on the decision of a foreign investor whether or not to go ahead with the realization in line with his primary motivation determined with structural factors. In short, an inadequate investment climate and regulatory and policy framework could turn away a foreign investor who would otherwise choose to invest as far as market, resource/asset or cost considerations are concerned.

Specific FDI policy is only one element of the investment climate; not the most important one, because even the best and most friendly policy towards foreign investors could not compensate for an inadequate regulatory-administrative and economic policy framework. What, then, is the scope and what are the policy considerations in favor of specific FDI policy? In the last two decades, we have witnessed two processes of relevance for the perception and features of FDI policies. The first is that intercountry competition for FDI has increased considerably which resulted in an overall liberalization of FDI regimes. The second is increasing convergence among countries in many aspects of economic systems, regulatory and policy framework. The more liberal FDI regimes are, the more similar to each other countries are, and the more similar their regulatory frameworks and economic policies are, the more important are other specific intercountry differences for location decisions of foreign investors. Specific FDI policy is the most obvious way for a country to make a positive differentiation from competitive locations. Countries are, thus, tempted to apply increasingly aggressive FDI policies and to offer increasingly generous investment incentives. This is especially so for member countries of the EU, which have a highly harmonized system, regulatory and policy frameworks.

In this context, FDI policy has become an increasingly important determinant of creating a good investment climate. If a country does not offer some additional benefits, and when other primary and secondary FDI relevant factors in two countries are more or less equal, foreign investors may choose to invest in another country with 'similar' basic conditions yet which offers additional benefits. These benefits simply become the norm, expected by foreign investors when looking for a suitable investment location. Activities to attract FDI can be grouped into: I) investment incentives, 2) image building, 3) direct acquisition of FDI and 4) provision of certain services for investors. There is a consensus among experts that image building of a host country, direct acquisition of FDI and providing certain services for foreign investors may be useful in attracting more and the right kind of FDI. Still, it is investment incentives, which are the core of FDI policy and whose pros and cons are repeatedly a matter of theoretical and policy discussions. 


\subsection{Economics of investment incentives}

FDI policies are a form of government intervention and this is justified when markets are characterized by either some distortions, such as externalities or the presence of market power, or because they are incomplete, which both lead to a socially inefficient outcome in competitive markets. The key arguments for government intervention are: I) presence of knowledge spillovers (see Griliches, 1979; 1992) and dynamic scale economies; 2) coordination failures; and 3) information externalities (Pack and Saggi, 2006; Rodrik, 2006). FDI is a typical source of spillover effects, which occur due to implementation of new technologies and other organizational knowledge and skills transfer, which are usually at a higher level than in domestic companies. Knowledge spillovers via FDI result from the inability of multinational corporations (MNCs) to fully internalize the benefits of superior knowledge. The presence of foreign subsidiaries can consequently increase the rate of technology improvements and technological learning in a host economy (Javorcik, 2004).

The rationale for policy intervention with respect to FDI has, thus, usually been associated with the potentially positive effect of FDI on the productivity of domestic firms via knowledge spillovers and linkage effects (UNCTAD, 2003). Spillover effects justify the incentives schemes to the point where private benefits equal broader social benefits. Incentives schemes are also economically justified when: I) their use attracts one or more leading foreign companies, which leads to other investors being interested in entry, 2) potential benefits of economies of scale and learning by doing, 3 ) when they compensate other costs investors might incur due to government intervention (Blomström, 2002; UNCTAD, 2002).

There are also reasons for care when designing an incentives package, especially when these are aimed solely at foreign investors. Governments must carefully weigh the costs against benefits in order to avoid certain situations (UNCTAD, 2002; Blomström, 2002):

- Offering of incentives to investors that would have invested anyway;

- Difficulties in calculating the value of externalities ex ante to the investment, problems of picking winners;

- Reduction of fiscal revenues (in the case of fiscal incentives) and/or increase of fiscal expenditure (in the case of financial incentives) reduce the amount of fiscal resources for other purposes (such as the improvement of infrastructure, education and training);

- Administrative costs related to managing incentive schemes;

- Potential efficiency losses if firms are induced to locate where incentives are the most generous and not where location factors might otherwise be the most favorable (UNCTAD, 2003, p. 124); rent-seekers behavior; 
- Competition among governments to attract FDI may create problems because there is a tendency to overbid and the subsidies may surpass the level of the spillover benefits.

The most important argument against investment incentives aimed only at foreign firms is the fact that spillover effects are not an automatic consequence of FDI, but depend on the absorption capabilities of domestic firms. The potential spillover will not be realized if domestic firms do not have the capacities or the motivation to learn from MNCs and to invest in new technology. This also implies that the effectiveness of incentives aimed at spillover benefits could be inefficient unless appropriately accompanied by measures to increase the learning capacity in domestic firms and measures aimed at strengthening competitiveness (Blomström, 2002; Damijan et al., 2008).

\subsection{Issues and trends in investment incentives policies}

Governments use three main categories of investment incentives to attract FDI and benefit more from it: I) financial incentives (for example, grants and loans at concessional interest rates), 2) fiscal incentives (for example, tax holidays and reduced tax rates) and 3 ) other incentives (for example, subsidized infrastructure of services, market preferences and regulatory concessions, including exemptions from labor or environmental laws). Among the latter, industrial, technological and science parks are an increasingly popular form of investment incentive aimed at both domestic and foreign investors, providing infrastructure, services and even location management to potential investors (see Kelleher and Thompstone, 2000). Incentives can be used for attracting new FDI to a particular host country (locational incentives) or for stimulating foreign subsidiaries to undertake functions regarded as desirable such as exporting, local sourcing, R\&D, and transfer of knowledge (behavioral incentives). Most incentives do not discriminate between domestic and foreign investors, but they sometimes implicitly target one of the two (UNCTAD, 2003, p. 123).

The use of locational incentives to attract FDI has considerably expanded both in volume or frequency as well as value. The widespread and growing incidence of both fiscal and financial incentives is well documented (Charlton, 2003; OECD, 2003, p. 124; UNCTAD, 1996; Moran, 1998; Oman, 2000; Blomström, 2002). In general, developed and transition countries frequently employ financial incentives, while developing countries (which cannot afford a direct drain on the government budget) prefer fiscal measures (OECD 2003, p. I24). Within the EU, investment incentives are, as a rule, directed to domestic and foreign investors alike but there 
can be measures within the incentives programs that are: I) not formally, but by their nature more oriented towards foreign investors (individually designed contractual regimes for large projects, special incentive packages for strategic investors, high-tech investments, regional hubs), 2) to some extent positively discriminative towards foreign capital, because they are trying to attract capital that would otherwise not enter a country (high-tech, not available domestically). Grants linked to R\&D investments - either by domestic or non-domestic firms - in particular have been on a rising trend in both developed and developing countries (European Commission, 2006; for detail see UNCTAD, 2005, chapter 7).

In creating an investment incentives policy, policymakers should tackle the following issues: I) kind/type of incentives, 2) level of incentives, 3) explicit or implicit incentives policy, 4) performance requirements, 5) diversification of investment incentives, and 6) delivery of incentives. More aggressive investment incentives policies are characterized by giving more accent to financial incentives, the possibility of differentiated treatment of foreign investors, and a need for a stronger role of investment agency. Recent trends in investment incentives policies speak in favor of the following principles and practices:

- Incentives policy should not be determined solely by the desire to attract FDI; it should be well incorporated into the national development strategy. In other words, investment incentives should be considered a part of an economy's development strategy and policies, rather than a policy area that is only of relevance to foreign investors.

- Investment incentives should be available on equal terms to all investors irrespective of industry and nationality of investor. The motivation for supporting foreign investors - including existing investors that may consider expanding their activities - is to equalize social and private returns to investment. The reason for subsidizing local firms is to strengthen their capacity to absorb foreign technology and skills (European Commission, 2006).

- Less general incentives and more incentives targeted at specific purposes, such as the introduction of new technologies, exports promotion, R\&D activities, employment, in particular of highly skilled labor, and environment friendly projects. Incentives should not be of an ex ante type that is granted prior to the investment, but they should instead promote those activities that create potential for spillovers. In particular, these include education, training, and R\&D activities (UNCTAD, 2005) as well as linkages between foreign and local firms (UNCTAD, 200I). An advantage of performance-based incentives is that they may affect the entire stock of investments, rather than just the flow of new investment.

- Also numerous experiences speak in favor of diversification and improvement of investment incentives structure. This can help to reach the same goals as an increased level of incentives, obviously at a lower cost. Numerous incentives are 
offered primarily by countries, aiming at attracting export-oriented FDI. Potential investors are also in favor of more diversified incentive schemes, because they can find a mix best suited for them. Therefore, it is often the case that a special incentives package is created for an important project, best suited to the needs of a particular investor. Such a 'case by case' approach raises the effectiveness of incentives programs and lowers their costs. A negative consequence of increasing diversity of incentives schemes is a decrease of their transparency.

- Within factor (financial and fiscal) incentives the share of grants and subsidies has been reduced, while the share of various repayable types of incentives has increased.

- Transition from automatic to selective/discriminatory/criteria-based awarding of incentives and stricter, frequently project-related monitoring of the effectiveness of incentives granting and sanctions in the case of not fulfilling the expected results have been increasingly applied.

To increase R\&D activities of MNCs in economies in transition and to strengthen knowledge spillovers from MNCs to local companies, Narula (2009) suggests several policy considerations for host countries. First, they should reduce the emphasis on cost advantages and increase the emphasis on specialized locationspecific assets, which implies developing and fostering specific industries and technological trajectories, such that the location advantages they offer are less 'generic' and more specific, highly immobile and conducive to 'locking' mobile investments into these assets. Second, attempts should be made to create clusters around MNCs, requesting from host countries to focus on attracting the kinds of FDI projects that provide the greatest opportunity for embeddedness and linkages between domestic and foreign firms. Third, MNCs should be helped to create linkages with local firms as the main driver of knowledge spillovers from FDI. Apart from that, he also has more general suggestions, specifically to improve opportunities for start-ups and small and medium enterprises (SMEs), to improve human resource capabilities, to build research capacities in the public sector, and to use all the available policy tools to promote R\&D.

\subsection{Effectiveness of investment incentives in transition countries in view of policy objectives, type and size of incentives and their delivery}

Effectiveness of investment incentives is no doubt a relevant issue for transition countries, as FDI has been a rather important factor of the transition process, and the growth and development of these countries in the last two decades (see 
for instance, Meyer, 1998; Hunya, 2000; Damijan et al., 2008). The level of foreign penetration in transition countries being the new member states of the EU is generally higher than in the old member states; in 2007, inward FDI stock to GDP ratio was $92.3 \%$ in Bulgaria, $78.0 \%$ in Estonia, $70.5 \%$ in Hungary, $57.7 \%$ in the Czech Republic, 53.6\% in Slovakia, 38.3\% in Lithuania, 37.5\% in Latvia, 36.7\% in Romania, 33.8\% in Poland and 27.7\% in Slovenia (UNCTAD, 2008).

Effectiveness of investment incentives could only be assessed within their potential scope to attract FDI. As claimed, empirical research has shown that investment incentives play only a secondary role in determining the international pattern of FDI (Blomström and Kokko, 2003). Incentives are important only when primary conditions of host country attractiveness - structural factors (market, factors of production) and investment climate - have been deemed satisfactory, that is to say, when two locations are closely matched in terms of the primary conditions (Guisinger et al., 1985; Rojec, 1994; UNCTAD, 1998; Oman, 2000). If the expected regulatory, business and institutional environment is not compatible to those in competing locations, no incentives can make a location attractive to FDI. Consequently, investment incentives for FDI can only be successful in the context of a broader strategy of improving the investment climate in a host country, which includes the creation of investment friendly economic policies (OECD, 2005).

Empirical studies for transition countries broadly confirm the limited effectiveness of investment incentives. Antaloczy and Sass (200I) claim that neither general nor econometric studies found any proof that incentives significantly impacted the direction or size of FDI in the Czech Republic, Estonia, Hungary, Poland, Slovakia and Slovenia. Among ten studies surveyed by Clausing and Dorobantu (2005), and those analyzed by Bevan and Estrin (2000), Bevan et al. (2004), and Garibaldi et al. (200I) only one found FDI incentives to play a significant role. Morriset (2003), who analyzed the functioning of 58 investment promotion agencies in transition and developing countries, finds that the effects of investment incentives without the necessary investment climate in the country can even be negative.

Within the limited scope of the overall impact of investment incentives on FDI flows and structure, there is, however, room for making incentives policy more or less efficient. Further on, we analyze the existing literature on incentives effectiveness with regards to different features of incentives policy. We put the effectiveness of incentives policy in the context of its objectives, types and structure of incentives, and delivery of incentives and operational capabilities of investment agencies. 


\subsubsection{Effectiveness of incentives and objectives of incentives policies}

Investment incentives policies have two main objectives: the quantitative objective of increasing FDI inflows or the number of new jobs created by FDI (locational incentives), and the qualitative objective, which aims to encourage certain behavior of foreign investors (behavioral incentives). Qualitative objectives usually focus on issues like investing in priority sectors or less developed regions, providing high-quality new jobs, export-oriented activity, engaging of domestic suppliers, transfer of technology, or R\&D in foreign subsidiaries. Here, two issues are especially relevant:

I It is difficult to evaluate the effectiveness of an incentive program without taking into account its objectives. If the incentives aim at increasing the inflow of FDI, then the indicator of effectiveness is an increased inflow of FDI or an increase in employment stemming from FDI, and not export propensity or technology transfer.

2 In practice, governments rarely pursue only quantitative or qualitative objectives. Usually, they pursue a set of different objectives, whereby the weight attached to various objectives is quite different in different countries. A government should never consider only how to increase FDI inflows, but also how to improve the quality of FDI and the links between foreign subsidiaries and domestic firms.

OECD (2003, p. I26) claims that incentives can be effective in attracting and influencing the location and behavior of foreign investors. But the economic desirability of locational incentives is not really clear. In fact, theory tends to suggest that, in principle, behavioral aspects of FDI incentives should have priority over the increase of FDI inflows as a policy objective (see for instance, Lall, 1996; Narula and Dunning, 2000). The case for incentives at the site, activity and behavioral level is stronger, but only when the setting is appropriate. Behavioral incentives are more likely to be effective in inducing benefits from FDI when complemented with other policy measures aimed, for example at enhancing the level of skills, technology and infrastructure quality.

Empirical analyses generally fail to find evidence of a positive impact of investment incentives on FDI inflows (see for instance, Morriset and Pirnia, 2000; Oman, 2000). Beyer (2002) employs a panel analysis of transition countries to find that the announcement of FDI promotion programs have little effect on FDI after other determinants are controlled for. An earlier study of transition countries by Holland and Ownes (1996) similarly only finds a marginal role for incentives in attracting FDI. Semihradsky and Klazar (20or) even found a negative correlation between investment incentives and FDI for the Czech Republic, 
Hungary and Poland, which they attribute to competition for FDI amongst similar locations in Central Europe.

Mallya, Kukulka and Jensen (2004) analyze the effectiveness of the Czech FDI promoting policies in attracting new inflows of foreign capital, the quality of incoming FDI and the cost-benefit aspect of FDI promotion. After the introduction of FDI promotion policies annual inflows of FDI into the Czech Republic more than doubled. Mallya, Kukulka and Jensen claim that most of the increase cannot be attributed to the incentives schemes as only some 10\% of additional FDI resulted from the incentives programs. Only a small number of investors decided on investing based on the incentives offered. A survey indicates that the program was successful in directing sectoral FDI as the sectoral structure of subsidized FDI differs greatly from those that were not subsidized. Findings also indicate that the incentive criteria used by Czechinvest have been successful in raising the quality of FDI (size, attracting greenfield projects and avoidance of cost-based investors).

According to Mallya, Kukulka and Jensen (2004), the Czech case points to a close interconnection between the inflow-increasing and behavioral objectives of FDI policies. If one realizes the behavioral objectives then the achievement of inflow-increasing objectives is less important. On the other hand, if the incentives program succeed to attract additional FDI, but at the same time lead to a 'lower quality' FDI, one may easily come to a conclusion about a negative costbenefit result of the program. The main conclusion of the Czech case is that governments should concentrate on FDI incentives programs that would in the first place improve the desired behavior of foreign investors and foreign-owned firms, rather than to set some inflows related goals. Apart from that, the governments should use instruments, which would stimulate additional domestic investment and spillover effects.

Explicitly or implicitly, integration of foreign subsidiaries in a host economy should probably be the main objective of any FDI policy; the higher the integration the higher the knowledge and other spillover from foreign subsidiaries to local firms. In the past, governments frequently attempted to 'force' foreign-owned companies into linkages with local companies by local content requirements, foreign equity ceilings and joint ventures, sometimes even by direct requests to transfer technology from abroad. This kind of approach has mostly proved to be unsuccessful. That is why requirements about specific behavior of foreign-owned companies have been mostly swapped by more flexible systems, in which foreign investors are offered incentives if they fulfil certain requirements about linking with local companies. In principle, investors can always decide not to take these requirements into considerations and, thus, not to get the incentives. With such a 'positive' linking of incentives and requirements, some countries successfully pro- 
mote interlinking of foreign-owned and local companies. The most often quoted successful cases are Singapore's Local Industry Upgrading Programme and Irish National Linkage Programme (Barry, 1999; UNCTAD, 200I, 2005).

\subsubsection{Effectiveness of incentives with regards to their type and structure}

The type and structure of investment incentives also contribute to their effectiveness. In principle, investors are supposed to prefer financial and other incentives (infrastructural assistance), especially subsidies and grants because these are usually obtained in the process of investing (building process, purchase of machinery) or at the start of business process. Fiscal incentives, alternatively, depend on the success of the project and they cannot be obtained unless the project is successful. On the other hand, host countries are usually more in favor of fiscal than financial incentives; while financial incentives are direct budget expenditures, fiscal incentives are only a renouncement of a potential budget income. The prevailing type of incentives also indicates a more or less aggressive character of incentives policy. The more the incentives scheme uses financial incentives, the more aggressive it is. Small economies, in which FDI is an important category and which strive to get export-oriented FDI, usually opt for more aggressive incentives schemes.

Empirical studies, especially those of a more recent date, do not really fit in the above theoretical predictions, at least as far as the impact on the volume of FDI inflows is concerned. Lower corporate profit tax rates and various tax exemptions seem to have a stronger impact on inward FDI than financial and other incentives. Taxes have been one of the most widely discussed incentives measures lately. The impact of taxes on investment behavior has been confirmed by numerous studies and the majority of them confirm that taxes do have a large and significant negative impact on investment (see for instance, Benassy-Quere, Fontagne and Lahreche-Revil, 2003; Billington, 1994; de Mooij and Ederveen, 2003; Pain and Young, 1996; Stöwhase, 2005). Studies which specifically include new EU member states are Bellak and Leibrecht (2007) and Vandenbussche (2005). The conclusion is that reduction of tax rates should have a positive impact on FDI. For policymakers these results indicate that tax policy can impact both the decision to target a specific location (country) as well as the decision about the size of investment.

Unfortunately, empirical analyses of the effectiveness of financial and other incentives are quite rare; for transition countries they do not exist at all. Mayer and Muchinelli (1998) analyze the impact of grants, subsidies, effective corporate tax rate, wage subsidies and structural funds on the Japanese FDI in the EU. Their results neither confirm nor reject the impact of the aforementioned incentives on 
Japanese FDI in the EU. Ferrer (1998) finds that the amount of funds from EU regional structural funds had a negative impact on the number of employees in the subsidiaries of French MNCs. The high level of government assistance was supposed to give a signal of 'underdevelopment' and thus caused the regions to be less attractive to investors. Hubert and Pain (2002) analyze the impact of the shares of gross public investment, state subsidies, structural European Regional Development Fund and effective corporate tax rate on FDI in EU. They find a positive and significant impact of public investment and corporate tax rate on the level of inward FDI.

\subsubsection{Effectiveness of investment incentives with regard to delivery of incentives and operational capabilities of investment agencies}

Selectivity in granting investment incentives has become a norm in many countries. Targeted investment support has a number of advantages in terms of minimizing costs and maximizing potential benefits of attracting FDI. Still, there is no consensus about the use of criteria in granting incentives. EBRD (2002) and other international institutions believe that incentives programs have to be combined with a 'hands-off' approach in targeting/selecting, in order to avoid the attempts to pick up the winners. UNCTAD (2002; 2003), on the other hand, favors the targeting of qualitative benefits through attracting export-oriented FDI, which helps further upgrade comparative advantages of recipient countries. OECD encourages incentives programs on a rules-based rather than competition-based approach (Oman 2000).

Morriset (2003), who analyzed investment promotion agencies in 58 transition and developing countries, lists the following findings with respect to their efficiency and guidance in attracting FDI:

- Agency efficiency is related to the general investment climate in the recipient country. Agencies in countries with poor investment climates will not be efficient in attracting FDI.

- Agencies that devote more funds to policy advocacy are more efficient as these activities benefit both foreign and domestic investors. On the contrary, investment-generating and investor-targeting activities are expensive and risky specifically in countries where the investment climate is poor.

- Agencies that have clearly established reporting mechanisms with channels to the highest government organs are systematically more successful in attracting FDI. Such institutional links are the key in strengthening the government's commitment, and reinforcing the credibility and visibility of the agency in the business community. 
Best-practice analysis of investment promotion agencies points to four principles crucial for efficient investment promotion and incentives policies:

I Predictability. Predictability is required in a clear policy and legal framework for investment, predictable rules and regulation and their just and consistent application.

2 Accountability. Public officials' accountability and efficiency can be improved by establishing clear standards and monitoring, which also reduces the chances of corruption.

3 Transparency. Initial contact and relations between a government and potential investors are best when necessary information is available on time, when it is easily attainable and when help for investors is well organized.

4 Participation. Open dialogue with the interested parties contributes to the evolution of incentives policies and their implementation (UNCTAD, 2004, p.4).

\subsection{Overview of knowledge-transfer related investment incentives in selected transition countries}

Empirical studies for transition countries broadly confirm the limited effectiveness of investment incentives. They tend to suggest that, in principle, behavioral aspects of FDI incentives should have priority over the increase of FDI inflows as a policy objective. Contrary to theoretical predictions, empirical studies, especially those of a more recent date, suggest that lower corporate profit tax rates and various tax exemptions seem to have stronger impact on inward FDI than financial and other incentives. Also, selectivity in granting investment incentives has become a norm in many countries. The aim of this section is to look the investment incentives programs of selected transition countries - Croatia, Czech Republic, Estonia, Hungary, Romania, Slovak Republic and Slovenia - from the perspective of the above findings. In doing that we concentrated on behavioral incentives, especially those related to knowledge transfers (incentives for investing in high-tech and R\&D activities), technology transfer, and training for industrial, technological and scientific parks.

\subsubsection{Investing in bigh-tech activities, RED activities, technology transfer, training}

Investments in high-tech industries are promoted within the context of nationaldevelopment strategies and there is no differentiation between foreign and domestic investors. Investments in these activities are promoted in the first place by tax incentives. 
The Hungarian Investment and Trade Development Agency focuses its support on high value-added investment projects, including a one-stop-shop service with a VIP treatment and comprehensive information about available subsidies for investment projects. For R\&D developments, investors are eligible for individual subsidies for projects of at least EUR io million or ten potential new job openings. The size of the direct subsidy is decided by the government. R\&D projects of at least EUR 400,000 are also eligible for 'development tax subsidy'. Other incentives are the same for other manufacturing projects above EUR io million or 50 new jobs, which include the following options: I) cash subsidy decided individually by the Hungarian Government, 2) development tax allowance ${ }^{3}$, 3) training subsidy $\left.{ }^{4}, 4\right)$ job creation subsidy $y^{5,6}$.

Croatia offers investment incentives for projects in the manufacturing sector, technology centers and strategic business support services in the form of tax and employment incentives, training incentives and additional incentives for large projects (EUR I5 million and Ioo new jobs), which also includes technological developments. For the projects related to technology and innovation centers a non-repayable grant of $5 \%$ of the actual eligible costs of investment in fixed assets is available. Also, in the case of the purchase of equipment for the technology and innovation center in question the maximum aid amount will not exceed EUR 500,000 , if the purchased equipment for the technology and innovation center is high-tech equipment. But the recipient of incentives 'must retain his eligibility status and maintain the investment and new employment linked to the investment during a minimum period of five years which shall not be shorter than the period in which it makes use of the incentive measures.'

The Czech Republic offers investment incentives for manufacturing projects (automotive, aerospace, electrical engineering and electronics, high-tech engineering, medical devices), services (medical services, IT and software development) and R\&D. According to the 2007 Investment Act, incentives span from corporate tax relief in the form of full tax relief for five years for new establishments and partial tax relief for expanding companies, regional incentives in the form of job creation grants of CZK 50,000 per employee and 35\% cost refund for training and retraining costs in the regions most affected by unemployment. But the total received funds must not exceed $40 \%$ (50\% in the case of medium enterprises, $60 \%$ in the case of small enterprises) of the investment made into long-term tangible and intangible assets, with the expectation of training and retraining funds. Eligibility of incentives depends on size of investment (CZK 50 million in least developed regions, CZK I00 million in most), minimum 50\% coverage by own equity and minimum $60 \%$ of total investment in mechanization. ${ }^{8}$

Investments in $\mathrm{R} \& \mathrm{D}$ and innovations (technology centers) and business support services centers are promoted and supported through several programs and 
are a constituent part of a strategy to support projects in progressive technologies and activities with high added value and strong export potential. In the last program, valid since April 2007, subsidies for training and retraining and subsidies for business activity are available (estimation based on sum for wages). But the investment must be at least CZK Io million and must open from 20 (Software development centers, ICT expert and solution centers) to roo new job posts (Customer contact centers). Investors must fulfill these conditions within three years after the support has been allocated and must keep eligibility for five years. International orientation of the project is also important. ${ }^{9}$

Estonia offers numerous programs and incentives schemes for different sectors. All projects can apply for the general start-up support (2008 plan) which offers start-up and development funds to help develop various activities. ${ }^{\text {Io }} \mathrm{A}$ Start-Up Grant, targeted at entrepreneurs that are ready to offer a product or service needed by the market, but that are not oriented to rapid growth, can be applied for in the amount of up to EEK 50,000. The maximum share of the grant in the cost of the project is $75 \%$. A Development Grant, targeted at entrepreneurs who are ready to offer a product or service needed by the market and that are oriented to rapid growth or who have already proven their competitiveness and need support for speeding up growth, can be applied in the amount of up to EEK 200,000. The maximum share of the grant in the cost of the project is $50 \%$.

For the R\&D sector, Estonia attempts to provide opportunities to launch new or improved products and services. The program creates a premise for the advancement of business competitiveness by introducing new and improved products and services to the market and implementing new technologies. The government participates by offering financial support through the program and sharing in the technological and marketing risks related to the projects. ${ }^{\text {II }}$ Estonia also offers grants for implementing applied research projects, the results of which can be used in the development of new or existing products, technologies or services. It provides up to $60 \%$ of the total costs directly related to a project, up to $75 \%$ of the costs directly related to a project where the project is in accordance with EU directives for $\mathrm{R} \& \mathrm{D}$ and where the project involves international cooperation between several parties, or even up to Ioo\% of the costs directly related to a project if its results are available to all enterprises and individuals on an equal basis and where the project is implemented for industrial purposes in cooperation with enterprises. ${ }^{12}$

Romania provides incentives for investments in the following sectors: activities of agro-industrial processing, top sectors in the manufacturing industry, electric and thermal energy production and delivery; production of equipments for increasing energetic effectiveness and use of renewable energy resources, environ- 
mental quality protection and improvement, water distribution, waste management, informatics and communications, research, development and innovation activities or new products development, and activities providing work force services. Incentives are of three types: granting nonrefundable funds for purchasing material and immaterial assets, granting state-budget financial contributions for newly created jobs, granting interest discounts for contracting credits, as well as other types of incentives provided by the legislation in force. The eligibility conditions depend on the investment (regional differences, potential spillover effects, technological characteristics, $\mathrm{R} \& \mathrm{D}$, environmental aspects) and the investors (business performance of firms in the past is taken into account). ${ }^{13}$

Slovakia ${ }^{14}$ offers the following types of investment assistance: investment aid to support initial investment and creation of jobs, which is provided in the form of: a subsidy for the acquisition of material assets and immaterial assets, an income tax relief under a separate regulation, a contribution for created new jobs under a separate regulation, and the transfer of immovable property or exchange of immovable property at a price lower than a general asset value. ${ }^{15}$ Slovakia offers incentives for industrial sectors, technology centers, centers of strategic service and tourism. For industry, grants are available for projects between EUR 6 million (in regions with unemployment at least 50\% higher than the Slovak average) and EUR 24 million (in regions with unemployment lower than the Slovak average). Technology centers investment must be at least EUR I.3 million, strategic services EUR I million and tourism between EUR 3.2 million and EUR 16 million, depending on the regional development, similar to the industrial projects.

Slovenia ${ }^{16}$ offers fiscal, financial and other incentives to potential investors. Investors can reduce the corporate tax base for a certain percentage of the values of: investments in research and development projects, for employment of disabled persons, training costs, costs of voluntary supplementary pension insurance, and donations. Slovenia also offers certain financial incentives, cost-sharing grant schemes. Grants are available for investments in: industry, strategic services (Customer Contact Centers, Shared Services Centers, Logistics and Distribution Centers, Regional Headquarters), and R\&D. The government FDI Cost-Sharing Grant Scheme can cover costs/expenses of the creation of new jobs, arising directly from the investment project, calculated for the period of two years (costs of gross salaries and compulsory contributions for social security); costs/expenses of material/tangible investments; costs of intangible long-term investments. There are also other incentives, especially those agreed individually on a regional basis and incentives for employing unemployed workers. 


\subsubsection{Industrial, technological, and science parks}

Increasing intercountry convergence of tax and financial incentives for foreign investors has led to the introduction of new types of incentives. One of the most promising types, with no discrimination between foreign and domestic investors, are industrial, technological and science parks ${ }^{17}$ Industrial parks, as a rule, include spatial planning with necessary road and other infrastructure. Building plots of different sizes are available to buy or hire, and standardized industrial premises are also available (Kelleher and Thompstone, 2000). Science and technological parks are usually closely interlinked with universities in the respective country. In the neighborhood of larger towns or outside big urban conglomerates the parks are managed by private companies, public organizations, such as local authorities (for example, the industrial park in Kolin, Czech Republic) or state-owned enterprises for the development of industrial parks (for example, IDA in Ireland). These kinds of parks act as an incentive for foreign investors, because they enable foreign investors to begin with their activities in a rather short period of time (they can buy or hire the prefabricated premises immediately or, alternatively, immediately begin to construct premises on the land, which they buy or hire) and, at the same time, offer a rather pleasant working conditions/environment to the employees. Transition countries are quite intensively involved in these kinds of attracting foreign investors.

Hungary offers a great number of industrial parks, which typically provide basic infrastructure (energy, water, waste-water treatment), a wide range of quality business services, including banking, consulting, security and office services, as well as customs administration and assistance in the creation of a supplier network. The projects are very successful ${ }^{18}$ : industrial parks contribute to $32 \%$ of the Hungarian GDP, companies located in industrial parks produce $31.4 \%$ of industrial exports and of the 50 largest MNCs present in Hungary, more than half are in industrial parks.

Croatia in its 2006-2013 development strategy especially outlines the importance of developing knowledge-intensive industries as the core of future development. Development of science and technology parks and business incubators are its key element. There are several technology centers and entrepreneurship and business incubators in Croatia. The collaboration between universities and businesses is also stimulated by TEMPUS supporting the formation of Entrepreneurship and Technology transfer offices in Zagreb, Split and Rijeka. Also important is the Business Innovation Center in Croatia, BICRO, a governmental run center, which runs several programs (RAZUM, TEHCRO, VENCRO, IR$\mathrm{CRO}, \mathrm{KONCRO}$ ) focusing on funding the development of innovations and new technologies based on entrepreneurship, increasing local competitiveness and increasing spillover absorption capacity. ${ }^{19}$ 
In the Czech Republic, promotion of development of technological centers and supporting business services is one of the most interesting incentives schemes. Almost 50 science and technology parks, innovation centers and business incubators are offered to investors and are at various stages of development. They are promoted as suitable for both larger $\mathrm{R} \& \mathrm{D}$ investments and small innovation projects. Technological centers intended for the development of innovations in production, centers for the development of software equipment, high-tech service centers, call centers for the support of customers, regional headquarters, and related high value-added services are eligible for incentives in the amount of 50\% of the project costs in the form of investment in fixed assets and/or salaries. Domestic and foreign investors are treated equally. ${ }^{20}$

Enterprise Estonia in its support measures for business, innovation and R\&D development for 2007-2013 focuses on the development of 'competence centers', which are established in cooperation between the industry and academic sector and carry out the research for developing products. In 2004, five competence centers were established with the help of Enterprise Estonia, working in the fields of cancer diagnostics and treatment, nanotechnology and sensory materials, designing and testing embedded systems, food and fermentation technologies, and healthy food products. ${ }^{21}$

Slovakia has also developed several industrial parks in the following regions: Banska Bystrica, Bratislava \& Trnava, Košice, Nitra, Prešov, Trenčin and Žilina. The parks offer accounting, marketing services, loans, investments, development and legal advisory services. The parks also attempt to create favorable conditions for development of SMEs. While applying modern technologies in production and concentrating on the production of high-tech products, they also offer innovation support, development of local scientific research activities and assistance with their result application in production and support export growth. ${ }^{22}$

Romania developed numerous industrial parks, which focus on a specific type of activity (for example, Dej park in the northwestern region of Cluj focuses on automotive parts, $\mathrm{UTA}_{2}$ industrial park in the western region of Arad focuses on logistics and light industry). The country also opened several free zones (for example, Curtici Arad free zone) focusing on promoting export-oriented production. PHARE assisted in creating some industrial zones (for example, Arad Vest industrial zone). ${ }^{23}$

Slovenia has gone through several stages of incubator and technology parks development. After the initial enthusiasm in 1992-1996, the Business Incubators Group (BIG) opened two technology parks (Ljubljana and Maribor). Due to a lack of consensus on the type of SME support and lack of financing, the 1996200 I period was marked by a downturn in this field, but from 2001 onwards, with the assistance of the PHARE program, the interest for business infrastructure 
has revived and also a law on SME support, clarifying the financial background for the projects, was adopted. Nowadays, Slovenia offers several technology parks (for example, Ljubljana, Maribor), business incubators and university incubators. ${ }^{24}$

\subsection{Conclusions and policy suggestions}

The focus of this chapter is on analyzing the investment incentives policies in transition countries from the perspective of the recent trends in investment incentives policies and their effectiveness in attracting more and better FDI. Specific FDI policy is only one element of the investment climate, but not the most important one. Even the best and the friendliest policy for foreign investors could not compensate for an inadequate regulatory-administrative and economic policy framework. Still, overall liberalization of FDI regimes and increasing convergence among countries in many aspects of economic systems, regulatory and policy framework, has made FDI policy an increasingly important determinant of a good investment climate. Nowadays, if a country does not offer some additional benefits, and when other primary and secondary FDI relevant factors in two countries are more or less equal, foreign investors may choose to invest in another country with 'similar' basic conditions yet which offers additional benefits. These benefits simply become infrastructure expected by foreign investors when looking for a suitable investment location.

Empirical studies for transition countries broadly confirm the limited effectiveness of investment incentives for inward FDI. Their finding is that, in principle, behavioral aspects of FDI incentives should have priority over the increase of FDI inflows as a policy objective. Contrary to theoretical predictions, empirical studies, especially those of a more recent date, suggest that lower corporate-profit tax rates and various tax exemptions seem to have a stronger impact on inward FDI than financial and other incentives. Selectivity in granting investment incentives has become a norm in many countries.

The overall impression from a brief overview of incentives schemes of selected economies in transition - Croatia, Czech Republic, Estonia, Hungary, Romania, Slovak Republic, and Slovenia - is that, apart from stimulating the creation of new jobs and investments in less developed regions, investment incentives are predominantly of the behavioral type, targeted to high-tech sectors, transfer of technology, R\&D, and training. In principle, incentives are equally available for foreign and domestic firms, but implicitly most of them seem to target foreign investors. Increasing attention is also devoted to the delivery of incentives, that is to say, to the assurance that the incentives granted will really bring the expected 
results. Overall, this is in line with what theoretical considerations and empirical evidence on incentives policies would suggest.

What then, are possible policy suggestions for transition countries with a view to attract more and better FDI? Conceptually, FDI-related policies should mainly be regarded in terms of potential spillover effects, meaning that the increasing of the local firms' absorption capacity is of paramount importance if FDI is really to become an agent of development (Damijan, Rojec, Majcen and Knell, 2008). The priority for action must be growth and stability-oriented macroeconomic frameworks, improvement of general framework conditions (reduction of rigidities and barriers on labor and product markets, adequate competition policies, availability of locations and premises, infrastructure), plus adequate innovation, $R \& D$, education and related policies. These are preconditions for attracting businesses and FDI. As far as investment incentives policy in the narrow sense is concerned, it should develop in the following directions: $\mathrm{I}$ ) to attract the right kind of FDI is more important than the amount of FDI, that is to say, there should be less general incentives and more incentives targeted to specific purposes, such as the introduction of new technologies, export promotion, $R \& D$ activities, employment, in particular of highly skilled labor, environment-friendly projects; 2) incentives policy should be well incorporated into the national development strategy and policies; 3 ) investment incentives should be available on equal terms to all investors irrespective of industry and nationality of investor, but some types of incentives will be implicitly more targeted to foreign investors; 4) allowing of individualized treatment of major projects and individually-tailored incentive packages which are more effective and less costly; 5) allowing investment agencies competent dealing with foreign investors; 6) delivery of incentives and monitoring of the results are important.

\section{Notes}

* This paper was prepared within the Sixth Framework Program project Understanding the Relationship between Knowledge and Competitiveness in the Enlarged European Union (U-know).

** Faculty of Economics, University of Ljubljana, crt.kostevc@ef.uni-lj.si.

*** Faculty of Economics, University of Ljubljana, tjasa.redek@ef.uni-lj.si.

$* * * *$ Faculty of Social Sciences, University of Ljubljana, and Institute of Macroeconomic Analysis and Development, matija.rojec@gov.si.

I Also, efforts to better inform foreign-owned firms on potential local suppliers have been intensified; for instance creation of electronic data bases on local suppliers, organizing of events where foreign-owned firms meet potential local suppliers, and so on.

2 ITD Hungary; http://www.itdh.com/engine.aspx?page=investment_incentives.

3 Development tax subsidy exempts the investor from paying $80 \%$ of the payable corporate tax for ten years following the completion of the project, but it is additionally conditional regarding size of the project and job openings. 
Training subsidies granted individually by the government depend on the size of the company and type of training and can reach up to $70 \%$ of costs with additional bonuses for training of disadvantaged employees and regional bonuses.

The incentive job creation subsidies reaching up to EUR I,04 million are regionally based programs for companies that open $50 \mathrm{I}$ new jobs in less developed regions or $20 \mathrm{I}$ in the least developed ones. But among new employees at least 50\% must be previously unemployed in less developed regions or at least $30 \%$ in the least developed ones. http://www.itdh.com/engine.aspx?page=logistics_facilities.

7 http://www.apiu.hr/Home.aspx?PageID=69.

8 http://www.czechinvest.org/en/investment-opportunities.

9 http://www.czechinvest.org/en/program-valid-from-april-I8th-2007-to-july-9th-2008.

Io These are: I) the acquisition of fixed assets required for implementing a business project (including transport and adjustment costs related to the acquisition); 2) creation and development of a website with information about the enterprise; 3 ) acquisition of applied software connected to the basic activity of the enterprise; 4) activities necessary for developing industrial design solutions and trademarks, and development-related activities; 5) acquisition of a patent, useful model, trademark or license for industrial design solution; 6) compliance assessment of the product produced by the enterprise.

I I For example, Enterprise Estonia's feasibility study grant has been designed for the purpose of preparing the development of new products, technologies and services in enterprises. It provides up to $70 \%$ of the expenses of a feasibility study for applied research and up to $50 \%$ of the expenses of a feasibility study for product development (maximum EEK 300,000 ). The total cost of a feasibility study may account for up to $25 \%$ of the project that follows the study.

I2 http://www.investinestonia.com/.

I3 http://www.arisinvest.ro/en/General-Framework.

I4 www.sario.sk; http://www.economy.gov.sk/index/go.php?id=2 I 3 I \&lang=en.

I5 http://www.sario.sk/swift_data/source/dokumenty/Investicie/pravidla/Act_Investment_Aid_eng.pdf.

I6 http://www.investslovenia.org/incentives/.

I7 They differ from traditional industrial zones by the very concept of organization. The basic difference between an industrial zone and an industrial park is that the latter is managed as a whole by the management who takes care of all the supporting aspects of relevance for the normal functioning of a park, that is to say security, cleaning, catering, bus transport, playground, etc. Organizational, business, spatial, environmental etc. standards in the parks are rather high. The ratio between construction and non-construction land is $30-40 \%: 60-70 \%$ for industrial parks of lower standards, and 25-30\%: 70-75\%, for industrial parks of higher standards. In the latter, there is also a greater accent on adequate architectural and landscape aspects (Kelleher and Thompstone, 2000). www.itd.hu.

I9 http://www.apiu.hr/Home.aspx?PageID =84.

20 http://www.czechinvest.org/en/r-d.

2 I http://innomet.ttu.ee/daaam/EnterpriseEstonia\%2oDAAAM\%202008\%2oplenary\%20 session_Vooras.pdf.

22 http://www.sario.sk/?industrial-parks.

$23 \mathrm{http}: / /$ arisinvest.ro/en/locations/industrial-parks-and-other-zones/.

24 http://www.erenet.org/papers/download/pres9.pdf. 


\section{List of references}

Antaloczy K. and M. Sass (200I) 'Greenfield Investments in Hungary: Are They Different from Privatization FDI?', Transnational Corporations Io(3), 39-59.

A.T. Kearney (1998) 'FDI Confidence Index', Global Business Policy Council I(2), December.

Barry F. (1999) 'FDI and Industrial Structure in Ireland, Spain, Portugal and the UK: Some Preliminary Results', University College Dublin Working Paper, University College Dublin, Dublin.

Bellak C. and M. Leibrecht (2007) 'Corporate Income Tax Competition and the Scope for National Tax Policy in the Enlarged Europe', in K. Andersson, E. Eberhartinger and L. Oxelheim, (eds.) National Tax Policy in Europe: To Be or Not to Be, Springer, Berlin.

Benassy-Quéré A., L. Fontagné and A. Lahreche-Revil (2003) 'Tax Competition and Foreign Direct Investment', Centre d'Etudes Prospectives et d'Informations Internationales (CEPII) Working Paper 2003-I7, Paris.

Beyer J. (2002) 'Please Invest in our Country' - How Successful Were the Tax Incentives for Foreign Investment in Transition Countries?', Communist and Post-Communist Studies 35, I9I-21I.

Bevan A. and S. Estrin (2000) 'The Determinants of Foreign Direct Investment in Transition Economies', Working Paper 342, William Davidson Institute, Ann Arbor.

Bevan A, S. Estrin and K. Meyer (2004) 'Foreign Investment Location and Institutional Development in Transition Economies', International Business Review I3, 43-64.

Billington N. (1994) 'The Location of Foreign Direct Investment: An Empirical Analysis', Applied Economics, 62, 1988-1997.

Blomström M. (2002) The Economics of International Investment Incentives, OECD, Paris.

Blomström M. and A. Kokko (2003) 'The Economics of Foreign Direct Investment Incentives', Working paper 168, Stockholm School of Economics, Stockholm.

Business International, Creditanstalt. 1992. East European Investment Survey, Vienna.

Charlton A. (2003) 'Incentive Bidding for Mobile Investment: Economic Consequences and Potential Responses', Working Paper 203, OECD Development Centre, Paris.

Clausing K. and C. Dorobantu (2005) 'Re-entering Europe: Does European Union Candidacy Boost Foreign Direct Investment?', Economics of Transition I3(I), 77-IO3. 
Damijan J.P., M. Rojec, B. Majcen and M. Knell (2008) 'Impact of Firm Heterogeneity on Direct and Spillover Effects of FDI: Micro Evidence from Ten Transition Countries', Centre for Institutions and Economic Performance (LICOS) discussion paper 218/2008, Katholieke Universiteit Leuven, Leuven.

Dunning J.H. (1993) Multinational Enterprises and the Global Economy, AddisonWesley, Wokingham.

Economic Commission (2006) Foreign Direct Investment and Innovation, ECFIN/EPC(2006)REP/53314, Economic Policy Committee, Working Group on Globalisation Brussels.

Ferrer C. (1998) 'Patterns and Determinants of Location Decisions by French Multinationals in European Regions', in J-L. Mucchielli (ed.) Multinational Locations Strategy, Research and Global Strategic Management, JAI Press, London.

Garibaldi P., N. Mora, R. Sahav and J. Zettelmeyer (200I) 'What Moves Capital to Transtion Economies', IMF Staff papers 48, Special Issue, IMF, Washington, DC.

Griliches Z. (1979) 'Issues in Assessing the Contribution of R\&D to Productivity Growth', Bell Journal of Economics 10, 92-116.

Griliches Z. (1992) 'The Search for R\&D Spillovers', Scandinavian Journal of Economics $94,29-47$.

Guisinger S.E. and Associates (1985) Investment Incentives and Performance Requirements, Praeger Publishers, New York.

Holland D. and J. Owens (1996) 'Taxation and Foreign Direct Investment: The Experience of the Economies in Transition', Bulletin for International Fiscal Documentation, 50(2), 46-66.

Hubert F. and N. Pain (2002) 'Fiscal Incentives, European Integration and the Location of Foreign Direct Investment', The Manchester School 70(3), 336-363. Hunya G. (2006) Integration through Foreign Direct Investment: Making Central European Industries Competitive, E. Elgar, Cheltenham and Northampton.

Kelleher T. and K. Thompstone (2000) 'Property Based Incentives for Foreign Direct Investment', Interno gradivo Urada RS za gospodarsko promocijo Slovenije in tuje investicije, TDI, Dublin.

Lall S. (1996) Learning from the Asian Tigers, Macmillan, Basingstoke.

Mallya T.J.S., Z. Kukulka and C. Jensen (2004) 'Are Incentives a Good Investment for the Host Country? An Empirical Evaluation of the Czech National Incentive Scheme', Transnational Corporations I3(I), I09-148.

Mayer T. and J-L. Mucchielli (1998) 'Agglomeration Effects, State Policies and Competition in the Location of Japanese FDI in Europe', in J-L. Mucchielli (ed.) Multinational Locations Strategy, Research and Global Strategic Management, JAI Press, London. 
Meyer K. (1998) Direct Investment in Economies in Transition: Making Central European Industries Competitive, Edward Elgar, Cheltenham.

Mooij R.A. de, and S. Ederveen (2003) 'Taxation and Foreign Direct Investment: A Synthesis of Empirical Research', International Tax and Public Finance io, 673-693.

Moran T.H. (1998) Foreign Direct Investment and Development. The New Policy Agenda for Developing Countries and Economies in Transition, Institute for International Economics, Washington, DC.

Morriset J. (2003) 'Does a Country Need a Promotion Agency to Attract Foreign Direct Investment? A Small Analytical Model Applied to 58 Countries', World Bank Policy Research Working Paper 3028 (April), World Bank, FIAS, Washington, DC.

Morriset J. and N. Pirnia (2000) 'How Tax Policy and Incentives Affect Foreign Direct Investment: A Review, Policy Research Working Paper 2509, World Bank, Washington, DC.

Narula R. (2009) Multinational Firms, Globalization and Innovations for New Member States of the EU, Paper presented at the workshop Innovation for Competitiveness INCOM Prague, 22-23 January.

Narula R. and J.H. Dunning (2000) 'Industrial Development, Globalization and Multinational Enterprises: New Realities for Developing Countries', Oxford Development Studies 28(2), I43-167.

OECD (2003) Checklist for Foreign Direct Investment Incentive Policies, OECD Publishing, Paris.

OECD (2005) A Policy Framework for Investment: Investment Promotion and Facilitation, OECD Conference Investment for Development: Making it Happen, 25-27 October, Rio de Janeiro.

Oman C. (2000) Policy Competition for Foreign Direct Investment: A Study of Competition among Governments to Attract FDI, OECD, Paris.

Pack H. and K. Saggi (2006) 'Is There a Case for Industrial Policy? A Critical Survey', World Bank Research Observer 2I(2), 267-297.

Pain N. and G. Young (1996) Tax Competition and the Pattern of European Foreign Direct Investment, Mimeo, National Institute of Economic and Social Research, London.

Rodrik D. (2006) 'Goodbye Washington Consensus, Hello Washington Confusion?', Journal of Economic Literature 44(4), 973-987.

Rojec M. (1994) Tuje investicije v slovenski razvoj, Znanstveno in publicistično središče, Ljubljana.

Sedmihradsky M. and S. Klazar (200I) 'Tax Competition for FDI in Central European Countries', Working Paper, University of Economics, Department of Public Finance, Prague. 
Smarzynska B.K. (2003) 'Does Foreign Direct Investment Increase the Productivity of Domestic Firms? In Search of Spillovers through Backward Linkages', William Davidson Working Paper 548, University of Michigan Business School.

Stöwhase S. (2005) 'Tax Rate Differentials and Sector Specific Foreign Direct Investment: Empirical Evidence from the EU', Working Paper, Ludwig-Maximilians-Universität, Munich.

UNCTAD (1996) Incentives and Foreign Direct Investment, Current Studies, Series $\mathrm{A}_{3} \mathrm{O}$, United Nations, New York.

UNCTAD (1998) World Investment Report 1998, United Nations, New York.

UNCTAD (200I) World Investment Report 2001, United Nations, New York.

UNCTAD (2002) World Investment Report 2002, United Nations, New York.

UNCTAD (2003) World Investment Report 2003, United Nations, New York.

UNCTAD (2004) Good Governance in Investment Promotion, TD/B/COM.2/ EM.15/2, 15 August. Trade and Development Board.

UNCTAD (2005) World Investment Report 2005, United Nations, New York.

UNCTAD (2008) World Investment Report 2008, United Nations, New York.

Vandenbussche H. (2005) Corporate Taxation in a European Perspective and the Position of Slovenia, Mimeo, Catholic University of Leuven, Leuven. 



\title{
$7 \quad$ Policies for attracting foreign direct investment and enhancing its spillovers to indigenous firms
}

\author{
The case of Hungary
}

Katalin Antalóczy*, Magdolna Sass ${ }^{* *}$ and Miklós Szanyi ${ }^{* * *}$

\section{7+1 Introduction}

Since 1989, Hungary has been among the leading Central and Eastern European (CEE) countries in attracting foreign direct investments (FDI). It was always the priority of various governments to attract FDI into the country, partly because of the specificities of the country's heritage from the socialist-communist period. This stance was translated into various policy measures, which were favorable - in some cases discriminatory - towards foreign investors, especially for those who undertook large projects in the country. This friendly approach to foreign investors has become a common feature of capital-lacking Central and Eastern European economies, with the possible exception of Lithuania, Poland and Slovenia. This rather descriptive chapter, after briefly describing the main characteristics of FDI in Hungary, presents in detail policies which tried to attract higher volumes of FDI and which have been aimed at increasing their positive impact on the domestic economy by promoting backward linkages. Two short company case studies, both on affiliates receiving substantial policy support, illustrate how companies may impact the domestic economy in different ways. A brief review of the literature provides the basis for evaluating the FDI policies of Hungary. In the following section, we try to extend our analysis by discussing the direct and indirect impacts of the global financial crisis on FDI and Hungary's policy responses to this crisis. The concluding section summarizes our main findings.

\subsection{Foreign direct investment in Hungary}

Hungary is a small open economy, which started the transition process from socialism to the market economy in 1989 . Compared to its neighbors it was more 
open to foreign investments even before 1989. At the beginning of the transition, it had a close to USD 400 million stock of FDI (Csáki, 200I), mainly in the form of joint ventures (JVs), due to the fact that the establishment of JVs was allowed by law since 1972. More significant volumes of FDI started to arrive to the country in I99I, reaching a peak point of the decade in 1995, connected mainly to privatization in the profit of foreigners. Since $1995^{\mathrm{I}}$, the annual inflow fluctuated in the range of USD 2 to 6 billion. While up till 1998 , new investments (equity) dominated the annual inflow, after that, additional investments of affiliates already present in Hungary in the form of reinvested earnings and other investments became more important. ${ }^{2}$

Hungary has been one of the leading countries among the East Central European countries (together with the Czech Republic and Estonia) in attracting FDI in per capita terms. At the end of 2007, the stock of FDI in Hungary was USD 97.4 billion, which represents around $0.65 \%$ of the world FDI stock; ${ }^{3}$ this is higher than the share of the country in world trade. Hungary is host to more than $22 \%$ of the stock of FDI invested in countries which joined the EU in 2004, which is higher than the country's share in the total population or GDP of the country group.

Figure 7.1 FDI stock per capita (2007, USD)

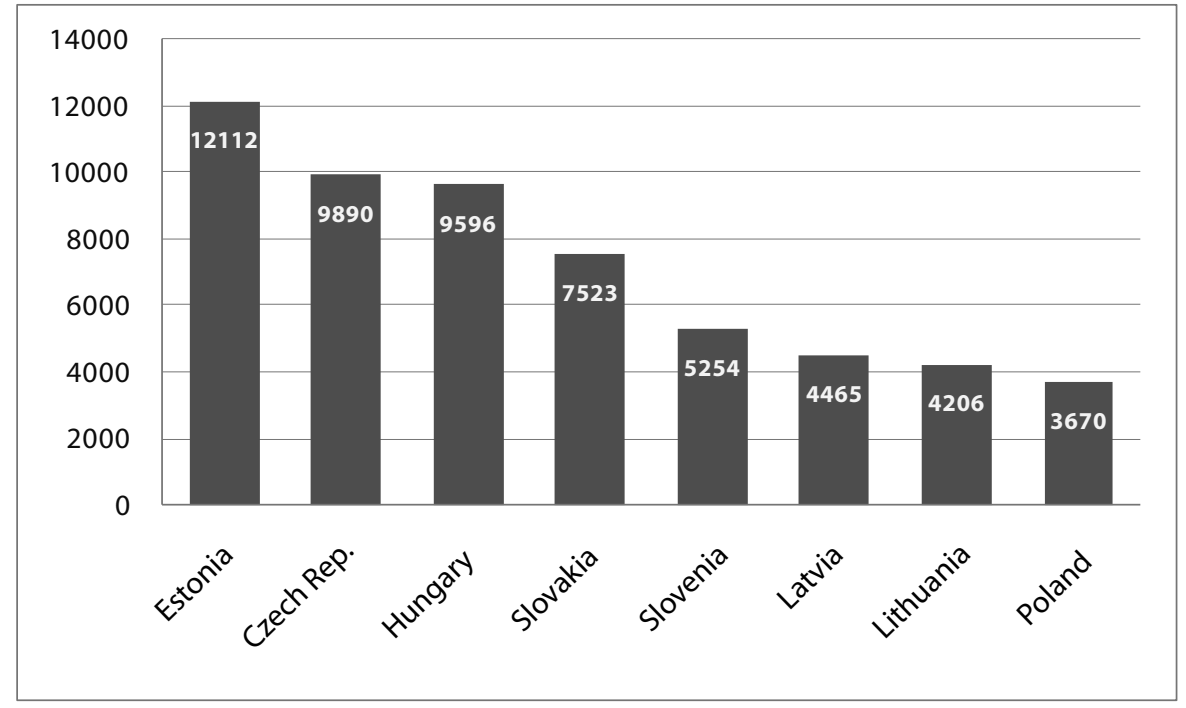


In terms of the absolute value of stock, Poland is the leader, and Hungary - taking turns with the Czech Republic - is second, similarly to per capita terms, where Estonia is the leader. The annual inflow represents a relatively high share of annual gross fixed capital formation (GFCF) in Hungary (on average around one third). The role of companies with foreign participation is high in the Hungarian economy, even in European comparison (for example in 2007, according to the data of the Hungarian Tax Authority, they accounted for $45 \%$ of gross value added, $46 \%$ of sales, $78 \%$ of exports, and employed around one fourth of workers.)

The most important foreign investor countries have been Germany, the Netherlands and Austria, ${ }^{4}$ which represented more than half of the overall stock of FDI basically in every analyzed year. Geographical and cultural proximity explains their dominance. While besides big multinational corporations (MNCs), also smaller-sized German and Austrian companies invested in Hungary, Dutch, British and especially US investors are mainly big MNCs.

The sector composition of investments changed considerably during the two analyzed decades. While in the first half of the I990s, the manufacturing sector was the most important target of foreign investors, after 1995, reflecting the timing and sequence of the privatization of public services and banks, these latter sectors started to gain shares in the overall stock of FDI. In 2007, the share of manufacturing FDI in total was $36 \%$, which is similar to other Visegrad countries (Czech Republic, Poland and Slovakia). Inside manufacturing, production of vehicles attracted the most FDI with its $30 \%$ share in 2007 , followed by electronics ( $17 \%)$. As an illustration, it is enough to name a few big MNCs present in Hungary with significant projects, such as Audi, Suzuki, Opel/GM in vehicle manufacturing or IBM, Flextronics, Nokia, Philips, or Samsung in electronics. Other important manufacturing branches are manufacture of petrol (Io\%), food, beverages and tobacco $(8.2 \%)$ and metalworking $(7.8 \%)$. These reflect partly the relative abundance of the country in relatively cheap and relevantly skilled workers (vehicles, electronics), its comparative advantages (food) and in metalworking, foreign-owned suppliers following their main clients.

Horizontal projects dominated in the first half of the I990s. Starting from 1995, more and more vertical investments appeared, mainly in manufacturing, and from 2000 on, vertical services FDI also appeared and gained importance, mainly in the form of shared service centers of big MNCs and independent business service vendors, such as EDS or IBM.

The regional distribution of FDI is usually determined by geographical considerations, transport facilities, other elements of the infrastructure and characteristics of labor endowment. Due to geographical considerations, companies with foreign participation are concentrated in and around Budapest, ${ }^{5}$ in the west- 
ern part of the country, along the Austrian border, and in the northwestern part of the country, especially in the town of Székesfehérvár. Emerging locations are Miskolc, Kecskemét, Debrecen and so on, in the eastern part of the country, due to the newly built motorways providing good connections to them and their good endowment with (semi-) skilled workers.

\subsection{Foreign direct investment policies in Hungary}

\subsubsection{Theoretical background}

Government policies influence the locational advantages (' $L$ ' in the OLI-framework of Dunning, 1993) of the given country through various channels. The general state of the host economy, its economic, legal and political stability, and its size, its geographical location and its relative factor endowment, that is FDI-incentives in a broader sense, are the most important factors for attracting foreign investors. On the other hand, FDI-incentives in the narrow sense consist of those elements of the economic policy that are aimed at the improvement of the return on FDI, and/or a reduction of its risks and/or costs. They do not include those non-discriminatory elements of policies, which provide for a 'normal, usual' business environment for investors. Incentives can be fiscal (tax-related), financial (grants) and other incentives (OECD, 1989). The FDI enhancing role of incentives in the narrow sense is widely discussed in the literature and empirical evidence is inconclusive concerning the impact of incentives on FDI flows, though there is more and more evidence on the impact of incentives on locational choices of investors (see for example Hassett and Hubbard, 1997; Wells and Wint, 2000; Clark, 2000; Taylor, 2000; Hubert and Pain, 2002; Morisset and Andrew-Johnson, 2004; Charlton and Davis, 2006; Bobonis and Schatz; 2007). Incentives in the narrow sense may certainly play a role in choosing between locations inside a region, ${ }^{6}$ which are otherwise performing similarly in terms of FDI incentives in a broad sense. This consideration can be valid for similar locations among the East Central European countries and/or inside Hungary. Here we analyze the evolution of the Hungarian FDI policy along these lines; first of all, we present the changes in the incentive system (in a narrow sense) together with changes in other elements of the economic policy, which influenced the overall FDI environment to a great extent (especially privatization policy). We present details about the most important elements of the economic and policy background, which determined or at least shaped changes in the FDI policy. 


\subsubsection{Foreign direct investment policies in Hungary: Increasing the volume of foreign direct investment}

In Hungary, overall, economic policies have been favorable for foreign investors during the two decades of the transition period. Hungary was the first country in the region which made possible the establishment of companies with foreign participation in 1972; however, 'real' FDI policy has been operated only since I988. In this period lasting more than two decades, there were many changes introduced in the FDI policy of Hungary. On the basis of the content (measures), uniformity, and level of transparency, three periods of FDI policy can be distinguished. The first one started in 1988 and lasted until around the mid-I990s, the second one lasted until the end of 2003, and the third one until now (Antalóczy and Sass, 2003). However, because of the financial crisis, a fourth period could be in the making at present.

\section{THE FIRST PERIOD OF FOREIGN DIRECT INVESTMENT POLICIES,} I989-I995

In the first period, at the beginning of the reform process, risks for foreign investors were exceedingly high, because a country started to allow the inflow of FDI, in which the share of state ownership was overwhelming. Moreover, the country could be characterized by acute lack of capital, grave problems of indebtedness, structural problems, institutional-regulatory 'chaos' and insecurity. Moreover, compared to other transition economies, there was less resistance to the market economy in Hungary both on the part of economists and on the part of the population, partly due to previous reform steps, which were introduced starting from 1968. In the risky environment of an underdeveloped market, instable budget, and high debt burden and in an era in which competition for FDI in the world economy became more and more acute, FDI policy evolved as follows. Hungary liberalized capital flows and built up the legal framework for FDI earlier in regional comparison. A big change in the regulatory environment for foreign investors came in 1988 , starting from when foreign investors were granted national treatment in all economic branches except for the financial sector. A $50 \%$ share could be obtained without prior permission, for shares above that, permission was needed. The 1988 law allowed the repatriation of all profits, granted duty free status for contribution in kind, and depending on foreign share, volume of investment and the sector of investment, it granted tax allowances and tax holidays. Thus, the most important elements of FDI policy were fiscal incentives, as in other less developed countries. The government gave up those incomes, which it did not have: future tax and duty revenues. On the other hand, in order to attract 
FDI in the sharper competition, the government tried to attract big, well-known MNCs, granting them one-off, tailor-made and generous incentives in the form of substantial tax holidays (for example for ten years) and other types of incentives (for example the possibility of operating in a free trade zone, see Box 7.2). These well-known companies, such as Suzuki, GE, General Motors and Ford, provided a kind of 'green light' for other investors. As a third element, which was different from the policies applied in other countries of the region, in Hungary, where there was an urgent need for currency for debt repayment, privatization policy was centered around selling state-owned companies for cash. In a country which was characterized by lack of capital, in most of the cases this meant privat-

\section{Box 7.1 Privatization and FDI}

Privatization and FDI are closely related in the period of transition (Kalotay and Hunya, 2000). In Hungary, a substantial amount of FDI was connected to strategic privatization projects until 1998. Since the start of the process, unlike in other competitor countries in the region, cash sales had prevailed over other privatization methods. However, the share of privatization-related FDI declined substantially, 1997 was the last year when a significant amount was registered in that respect.' Other countries in the region started to sell stateowned companies to foreigners later compared to Hungary. The share of privatization revenues in FDI became substantial only after 1995 in Poland, after 1998 in the Czech Republic and after 2000 in Slovakia (Chart 2).

The share of privatization related FDI in the total inflow of FDI follows the same pattern in the three countries with a time lag. There are many problems in determining the share of privatization - related FDI in total (see for example Sass, 2005 for the list of data problems and the 'underreporting' of privatization-related FDI), but even incomplete data show a clear and diverging pattern for the period 1996-2002 for the three countries, for which data are available. Besides different timing of privatization of state-owned companies, involvement of foreign investors in capital-intensive infrastructure projects and privatization of public services to foreigners also happened at different times, Hungary being a clear forerunner in that respect.

Thus, the FDI performance of economies in transition cannot be judged without taking into account the share of privatization-related FDI. The large inflows of FDI to Hungary can partly be attributed to privatization deals until around 1997, that is in the first period of FDI policy. However, privatization-related FDI itself also had an impact on further inflows, first, due to creating a more market-like environment through its presence in the country and giving a good signal to other potential investors, second, because these projects attracted further FDI: suppliers, service providers, competitors and so on started to invest in the country, third, because the regulatory environment had to be adapted to the requirements of these companies, that is by creating and enforcing market economy laws and regulations. However, after 1998, privatization-related FDI has been negligible in Hungary, partly because the government 'run out of' suitable companies, while in other Visegrad countries their share still has been significant. 
Figure 7.2 Share of privatization-related FDI in total FDI (\%)

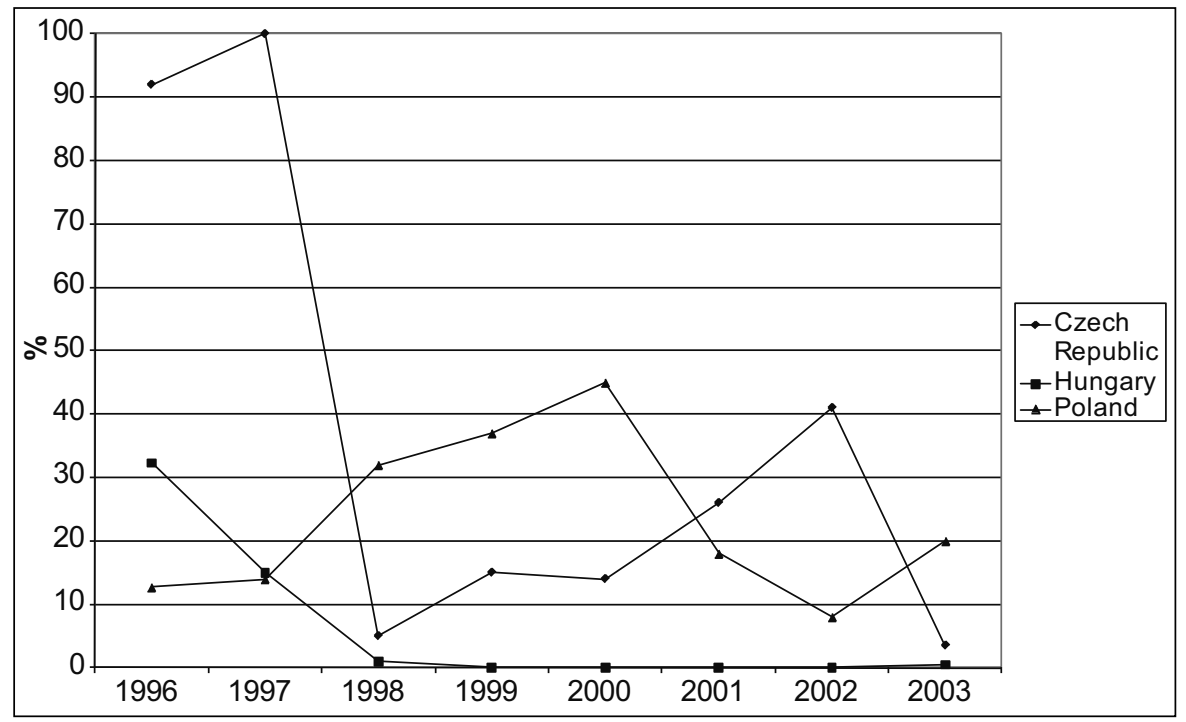

Source: Sass (2005)

izing to cash-rich foreigners. In some cases, even (quasi-)monopoly positions, (temporarily) protected markets were sold to foreign investors. As a fourth element, FDI in certain sectors was preferred, while the regional element (trying to divert investments to more backward regions) was not present at all. Until 1993, a positive discrimination towards foreign investors was introduced where preferences were given only to companies with foreign participation. After the abolishment of this discriminatory regulation in 1993, other elements of the system of incentives (for example high minimum investment requirement) secured the survival of the preferential treatment of foreign investors. In 1993, the national institution of FDI promotion, ITDH, was established.

THE SECOND PERIOD OF FOREIGN DIRECT INVESTMENT POLICIES, 1996-2003

In the second period, starting from 1996, the economic and political environment of FDI promotion had changed substantially. The institutional and regulatory background of the market economy was more or less present and functioning, the macroeconomic environment was much more stable. The economy grew at positive rates (at relatively high rates until 200I). The reduction of the profit 
tax to $18 \%$ resulted in a favorable environment for all the investors (domestic and foreign alike). Compared to other transition economies, the stock of FDI was already high in Hungary, and certain regional 'hubs' of FDI were established (namely in the northwestern and central parts of the country). Not only the environment changed, but also certain obligations, taken up in international organizations (mainly in the WTO), induced changes in FDI policy. Moreover, negative experiences connected to tailor-made incentives and concerning certain foreign investors also induced the government to change the system. The FDI policy of this period could be characterized as more transparent and more normative. It became also more active in terms of targeting: it tried to divert FDI to certain sectors, regions, activities, and applied more performance requirements as prerequisites for getting the fiscal, financial and other incentives. FDI policy was also used to attain other policy aims (for example, as a tool of industrial policy, regional policy, trade policy, R\&D policy, labor policy). One of the focuses of FDI policy was to attract export-oriented large investments (in manufacturing). Big investments were clearly preferred: it can be shown by the fact that the number of enterprises enjoying the greatest benefits of a $\% \%$ company tax was less than 50 in 1999 (Antalóczy and Sass, 2003). There was also attention paid to the enhancement of spillovers from companies with foreign participation to the local/domestic economy, because a special supplier program was launched. ${ }^{8}$ Fiscal elements still dominated, but financial incentives gained importance. Other incentives, especially industrial free trade zones (IFTZs), were also important. This second period of the FDI policy can be characterized as the 'heydays' of IFTZs because more than a hundred companies operated there. There was an important change in this second period in the neighboring countries of Hungary in terms of FDI policies: a kind of regional FDI competition started, when in 1998, the Czech Republic and in 2000, Slovakia introduced very generous systems of incentives for foreign investors and privatized companies by selling them to foreigners. The incentives offered by these countries were in some cases more generous than those provided in Hungary (for example, lower minimum investment requirements), which, as these countries became more and more similar as investment sites, probably affected locational choices of investors (Sass, 2003).9

\section{THE THIRD PERIOD OF FOREIGN DIRECT INVESTMENT POLICIES}

The third period of FDI policies started in 2003, and its main content was the transformation and operation of FDI policies alongside EU rules. Competition and investment incentive policies have always been in conflict with each other in the EU regulations. During the previous enlargements, partly due to spe cial economic-policy circumstances, catching up of the new member states was 


\section{Box 7.2 Industrial free trade zones}

The regulation concerning IFTZs was introduced first in 1982 with the objective of attracting export-oriented, high technology FDI to Hungary. International examples of similar schemes can be found in the export processing zones of developing countries, the customs-free zones of Ireland and the United States. At the same time, another objective was to integrate the companies operating in IFTZs as much as possible into the host economy, and eliminate the risk of a dual economy evolving. This risk is usually present with such regulations, for example, on the basis of the experience of developing countries.

The regulation of IFTZs was unique in Hungary. Any company could set up its own zone without geographical restrictions of any kind under license by the customs and finance authorities. IFTZs were considered as being extraterritorial for purposes of duties, foreign exchange and other legislation. The dutiable goods and means of production (excluding building and auxiliary material) were not subject to customs duties and value-added tax. Why is that regulation especially attractive for (export-oriented) greenfield investors? Since 1996 , contribution-in-kind could be transferred to the country duty- and VAT-free only for investments realized in IFTZs. For these large-sized investments, paying the duties and VAT would have meant high additional costs. Another reason for the growing number of companies in IFTZs was that companies operating there could buy their inputs from the domestic economy with a special permission and up to a certain amount duty free. Thus, traditional suppliers following their buyers to Hungary established their affiliates in an IFTZ as well. Moreover, these companies operating on an IFTZ did not face a currency risk, because they could keep their accounts in foreign currency. This was an extremely attractive regulation for assembly companies using only local labor as it enabled them to bring in high-value equipment free of duty for their own use.

Starting from 1990, there have been more and more IFTZs established in Hungary. First, a number of MNCs carried out greenfield investment in Hungary in an IFTZ (for example General Motors, Suzuki, and Philips). Later their competitors or suppliers followed them and established their Hungarian affiliate in an IFTZ (Ford, Audi, IBM, Nokia, LEAR Corp., United Technologies, Sony, Zollner) as well as companies, which identified East Central Europe as an attractive investment location around that time (like Benetton).

At the end of 2001, there were more than a hundred IFTZs established in Hungary. Philips (computer monitors, telecommunication products) operated more than one IFTZ, as well as the LEAR Corp. (producing car seats and other car parts). According to one estimation, based on company interviews, of the 115 IFTZs operating in Hungary in 2001, about 70-75 were established through greenfield investment (Antalóczy and Sass, 2001). The share of foreign capital exceeded $90 \%$ in all the base capital of IFTZ companies.

With the EU-accession of Hungary, all companies operating in a customs-free zone became part of the customs territory of Hungary, thus IFTZs ceased to exist.

Source: Antalóczy and Sass (2001)

considered to be more important, thus competition policy aspects were pushed in the background, characterizing the last two rounds of enlargements by the priority of competition policy aspects concerning state aid. This can partly be 
explained by the intenser incentive and tax competition and partly by the increasing importance and incidence of relocations from Western to Eastern part of Europe (Hunya and Sass, 2005) and as a consequence, losses of unskilled jobs occurring in Western Europe. Countries joining the EU in 2004, had to change their incentive systems alongside EU lines. One side effect of that change has been that regional incentive competition became limited, by the rules which put a cap on aid intensity according to the level of development of the affected region, and there is a set of accepted forms of aid. Moreover, new member states had to 'streamline' their incentive systems, to define clear targets and priorities, concerning the type of activities, regions or even sectors. Those areas, where there is a greater maneuvering room in terms of incentives, are favorable from the point of view of a catching-up country aiming at higher growth rates $(R \& D$, education-training, preference for less developed regions), however, they limit the possibilities for an active industrial policy. On the other hand, those elements of the FDI policy in a broader sense are allowed, which try to improve the overall business environment, such as lower taxes, infrastructure developments, establishment of industrial parks. As a consequence of the change of the incentive system, emphasis is put on financial and other incentives, and fiscal incentives are less important. In the Hungarian case, preference is given to big (job-creating) projects, to export-oriented service sector investments, and (both Hungarian and foreign) investments realized in preferred sectors. Exceptionally big investments creating a high number of jobs in less developed regions can receive a ten-year tax holiday. Financial incentives are confined to education, training and job creation. Special financial incentives can be offered to big (above EUR io million) investments, which create a high number of jobs. Companies can apply for financial support in the framework of EU co-financed operative programs (shared service centers, R\&D, tourism and so on). As far as other incentives are concerned, ITDH provides institutional support, there are industrial parks and accredited clusters, infrastructure developments, and special incentives can be offered by local municipalities (for example, tax reductions or holidays from local taxes).

\subsubsection{Programs for enhancing the local impact of foreign direct investment: Supplier programs}

As was already mentioned, starting from the second period of FDI policies, special attention was paid to enhance local spillovers of FDI in terms of backward linkages. Here we present the related programs in detail since Hungary was the first to introduce this kind of program among the East Central European countries. 
Already in the second period of FDI policies, the majority of Hungarian manufacturing production capacities became foreign-owned. A high level of productivity was achieved through the application of state-of-the-art production systems and a high level of specialization. Most Hungarian affiliates were integrated in international production networks. However, this kind of specialization, as well as the sudden and effective technological upgrading of production equipments did not favor Hungarian-owned companies to join as equal or even as lower-level suppliers. Hungarian firms largely remained outside of the international production networks, since they were small, technologically and financially weak, and in this early phase they also lacked sufficient managerial expertise in organizing their work according to the tight rules and delivery schedules of large MNCs. An important split of the economy evolved, namely an ownership-specific duality (see for example, Pavlinek, 2004; Antalóczy and Sass, 2005; Fink, 2006; Ellison, 2007;). Due to inherited financial, technological and managerial bottlenecks but also because most medium-sized or large companies were sold to foreign investors, Hungarian-owned firms were simply too small, weak and inexperienced to become partners. Another main reason was, however, that typical activity areas of Hungarian and foreign firms were largely different. They could not become partners simply because they were in different businesses. As is described by several studies (for example ITDH, 2002; Szanyi, 2002) main local suppliers of large MNCs in the automotive or electronics sectors were usually facility management, catering, cleaning and other services firms. These companies were of course not linked to the MNCs technologically; they did not participate in the actual production process.

The first explicit supplier-promotion policies were aimed at strengthening Hungarian firms and enabling them to become production partners of large MNCs. Efforts were also made at carrying out competence mapping among potential Hungarian suppliers, and government agencies started to carry out matchmaking between local and foreign-owned firms. MNCs' needs were registered, but even more important was gathering information about their supplier selection policies and practices. Government agencies provided information about the types of products, technical requirements and parameters of deliveries that large firms were looking for. This information was completed with practical guidelines about how these needs were actually fulfilled and how potential suppliers could successfully apply.

Starting in 1998 a number of explicit supplier-promotion policies were applied by Hungarian governments. Later these policy tools were inserted into broader development policy projects, and the special promotion agencies were also amalgamated into other enterprise promotion agencies like the Regional Development Plc. and International Trade Development Agency. The explicit focus on 
supplier development vanished however; this topic became a long-term preference of many Hungarian development programs instead, including the National Development Plan.

\section{THE SUPPLIER TARGET PROGRAM OF 1998}

The Supplier Target Program (STP) recognized that the major bottleneck of increasing Hungarian contributions was weaknesses of local small- and mediumsized companies (SMEs). It aimed at the creation of direct links between foreign investments enterprises (FIEs) and Hungarian firms in selected industries: automobile, electronics and rubber and plastics. In doing so it focused on providing information and matchmaking, as well as training and consulting to SMEs, the would-be suppliers. Hungarian firms, especially SMEs, were set in the center of the program. It wished to support preparations of SMEs to fulfill requirements. Main partners of the program were the local chambers of commerce, the Hungarian investment promotion agency (ITD Hungary), the Hungarian Foundation of Enterprise Development (HFED) with regional networks and the STP Program Office. HFED and the chambers organized training programs for SMEs to learn in general what MNCs looked for and how to cooperate with them. They also provided advisory support and supported the audit of SMEs' books. ITD Hungary managed a large-scale database with files of some 250,000 entrepreneurs (many of them quasi-entrepreneurs) and provided information for matchmaking. The main forum for matchmaking was a series of business meetings and suppliers' fairs, where the two parties were to meet where SMEs were expected to receive specific information about requirements. State mediators of the program wished to support SMEs' specific needs in the preparation process for the qualification.

These focuses did not prove to be efficient. The program did not take into account two important factors: first, FIEs had differing interests; second, there already were Hungarian mediators (first-tier suppliers) present in the market. A very critical evaluation of the STP from 2000 deemed the program a failure (MVKHT, 2000). Almost all the activities carried out in the program failed to bring the expected results. Most striking was the fact that a full-scale questionnaire survey reported only a couple of dozen of new contracts resulting from the program. Deepening of the pool for contracting was not successful either. Only relatively few SMEs could sufficiently improve activities to succeed in the program. On the other hand, the program was not able to attract the interest of FIEs either. This was partly because sourcing decisions in FIEs were not taken locally and the contacts of FIEs sourcing personnel needed higher level involvement (Út-Eurocon, 200I; Réthi, 200I; GM, 200I). 


\section{THE SUPPLIER INTEGRATOR TARGET PROGRAM OF 2000}

The Supplier Target Program was reconsidered in 2000, and the new Integrator Supplier Target Program (ISTP) was launched the same year. The new Program focused on existing supplier networks in the targeted industrial branches. In the center of these was the core company, the Integrator. The Integrator firm was the primary partner of the state agent. The first chosen Integrators were Suzuki, General Electric, Audi, Opel and Rába. The Integrators actively contributed to the planning and creation of a cooperation network, a business cluster. Cluster meant in the concept the cooperation of suppliers, innovative companies, $R \& D$ centers and local development agencies. The development of business clusters was also supported by the Széchenyi Plan (the predecessor of the National Development Plan). The state partner of the Integrators was the local office of the Regional Development Corporation (RDC). The RDC's activity was expanded with the management of both the ISTP funds, and the cluster development funds of the Széchenyi Plan. Beside RDCs, new Supplier Agencies were to be established based partly on the network of the Hungarian Enterprise Development Foundation, but also other local institutions (chambers of commerce, offices of ITD Hungary, and so on) applied for the status.

The basic idea of the new Program was that existing supplier networks could be further developed as a nucleus of a bigger and complex cooperation network, a local cluster. It changed the direction of the promotion activity to the opposite: it started with the needs and requirements of FIEs and other integrator firms. The primary purpose of the program was to increase local suppliers' share from the actual estimated $10-20 \%$ to $30-40 \%$ of MNCs' value added. Matchmaking events were continuously organized, and there were plans to update the established database and even expand it to 4,000-5,000 records. Training and advising SMEs still remained on the agenda, qualification and auditing of supplier members of the program were also foreseen (with financial support from the program sources). Long-term finance for necessary investments in supplier firms was also planned by the new Program. This should have included both loans and equity participation (venture capital function). Support of quality insurance programs also remained in place. A new state support agency regularly monitored the system and kept continuous contact with the participants.

The new program's main contradiction was its conflict with general economic policy. While it was aimed at decentralizing supplier promotion, simultaneously strong centralization efforts in economic policy were done by the government. Many of the tasks of ministries and development agencies were reallocated to the Prime Minister's Cabinet. Support of industrial clusters and innovation, as well as the general framework of the Széchenyi Development Plan were all allo- 
cated to the Cabinet. Supplier promotion was more and more integrated in more general policy programs, thus the decentralized institutional structure soon lost influence (Szanyi, 2002). Centralization tendencies remained strong until 2007, when a new shift in policy focus occurred that strengthened the role of regional development agencies.

\section{THE SUPPLIER PROGRAM OF 2005}

Supplier network promotion remained top priority of the Hungarian development policy, and the government decided to give new impetus to this policy. Basic principles and institutions of decentralized organization (based on regional development agencies), ITDH's role as matchmaker and data provider remained. Focus also remained on the strengthening of existing supplier linkages, rather than creating new ones. As a new element of the program, the government re-established a separate financial support scheme for supplier network development. While other development projects remained open for the task, HUF 25 billion (around EUR 90 million) was allocated in the framework of the 'Successful Hungary' Credit Program to be used by Hungarian SMEs for technology up-grading and product development necessary for becoming FIEs' suppliers.

In 2002 RDC established a new financial institution, the Supplier Investment Co. This institution worked as a venture capital fund concentrating on investments in some government priority business areas like biotechnology, waste management and logistics. This fund was charged in 2005 with the task of extending the supplier development credits. The credit was provided by the Hungarian Development Bank. Other tasks of the Supplier Program were the establishment of operating forums with the participation of suppliers and FIEs, extension of the database of ITD Hungary, and the creation of supplier competence centers that would deal with training and advising of potential suppliers. These tasks were by no means new. Their incorporation in another development project can be regarded as a strong criticism of the previous approach. Promotion of local cooperation networks need local coordination and platforms. Centralized policy tools could not efficiently promote this task. The new Supplier Program intended to rely very much on the experiences of the so called 'Suzuki pilot project', which was launched at the start of the Program in June 2005. Suzuki has always been one of the most interested FIEs' in local supplier networks. This is due to the local content requirements of the EU towards overseas companies. In this project I8 Suzuki suppliers (later 29) were monitored for their bottlenecks and development needs to improve or increase supplies. Suzuki evaluated the companies and organized on-site training in Japan. ITD Hungary drew conclusions after 
completing the project asking participants in a questionnaire about their experiences. The follow-up study reported that supplier capabilities were substantially improved. Firms carried out new investments (HUF 6.38 billion) and created 533 new jobs in the following two years. The new capacities were mainly used for supplies to Suzuki.

Using the experiences of the Suzuki pilot project, ITDH and the government decided to approach further integrator firms with the aim of launching similar supplier development programs. In a 2007 paper ITDH estimated the number of OEMs and final assemblers present in Hungary to reach 600. They may rely on the supplies of some 8,000 potential suppliers (ITDH, 2007). As a second step ITD Hungary wanted to repeat the Suzuki project with five to ten further main integrator FIEs each year. Negotiations were started with FAG, Claas, National Instruments, DANA, Electrolux and Bosch. The third leg of the Supplier Program is the Services Module which includes basically the same services that also previous projects performed: consulting, training, auditing, supplier information platforms, and database. These are coordinated and in many cases also performed by ITD Hungary's staff. As a new element, a supplier e-market and supplier competence center is to be developed, and a nationwide supplier forum is to be organized.

\subsection{How efficient are foreign direct investment policies? Overview of the empirical literature}

There are no studies and calculations available on the effectiveness of Hungarian FDI policies. These are lacking in other East Central European countries as well, and even if they exist, they are burdened with many methodological problems. The existing empirical analyses in most of the cases examine the impact of (effective) tax rates, that is, of only one element of FDI policies. Bellak et al. (2005), for example, summarizes the results of papers dealing with the link between tax rates and FDI in the analyzed region, which could not find a link between these two. However, the above-mentioned authors put into question these results, calling attention to methodological problems in terms of using nominal instead of effective tax rates and the differing impact of these tax rates on the three components of FDI inflows. Lipsey (2006) also calls the attention to methodological problems of these analyses, and he suggests that instead of FDI inflows, output, sales or employment data should be used as dependent variables.

Specifically for Hungary, a questionnaire-based study shows that exceedingly big FDI projects in Hungary received generous government support at the beginning of the I990s, which played an important role for the investors in choosing 
Hungary over other CEE locations ${ }^{10}$ (Antalóczy and Sass, 2003). Similar cases are cited in another article on the basis of case studies of FDI choosing locations in Poland, the Czech Republic or in Slovakia (Mah and Tamulaitis, 2000, pp. 236-237).

Empirical evidence is similarly inconclusive for the (positive) impact of FDI on the local economy in a group of or individual CEE countries (see for example Knell, 2000; Damijan et al., 2000; 2003; Campos and Kinoshita, 2002; Javorcik, 2004; Javorcik and Sparateanu, 2003; Kosová, 2005; Gorodnichenko, Svejnar and Terrell, 2007). Results are similarly inconclusive for Hungary (see for example Bosco, 2001; Schoors and van der Tol, 2002; Novák, 2003; Halpern and Muraközy, 2007). There are no specific analyses on the effectiveness of supplier programs in terms of raising the level of local value added or raising the number of local (domestic) suppliers. Understandably, there are no analyses on the cost effectiveness of FDI policy and supplier programs in terms of weighing the costs of incentives and programs against the benefits accrued.

\subsection{Two company case studies}

Empirical studies could give only a hint of the efficiency of Hungarian FDI policies. In this section, we present in detail two company case studies. Both are affiliates of well known MNCs, establishing a substantial capacity in Hungary, receiving significant government support (financial, fiscal and other incentives) and following completely different strategies in terms of their contacts with the local economy, which can partly be explained by the specificities of the products and partly by the differences in the strategy and organizational structure of the MNCs. With these two case studies we would like to illustrate that FDI incentive government policies favoring foreign investors may have completely different outcomes in terms of benefits for the host economy. ${ }^{\text {II }}$

\subsubsection{Electrolux-Lehel}

The Lehel Company was established in 1952. It employed 4,600 workers in I991 in Jászberény, and produced 470,000 refrigerators, of which 300,000 were sold on Western markets - though under the brand names of Western companies (HVG, I9 October, 1991, p. 87). It was privatized by the Swedish Electrolux in March 199I. The Swedish company paid USD 83 million for the Hungarian company (HVG, 5 October 199I, p. 79). However, because the surroundings of the company plants were contaminated by dangerous wastes, as part of the privatization deal, the Swedish Electrolux took up the responsibility of cleaning up the 
area, though they could deduce the related costs from the price paid for the company. According to HVG, in October 1992, the magnitude of related cleaning costs was determined as close to half of the total price paid for the Hungarian company (Páczi and Eörsi, 1993).

Further investments were carried out later by the company, when - after restructuring the acquired company - they extended the production capacities, and established new capacities (for example, for the production of vacuum cleaners or freezers) on the original site in Jászberény and established a new plant in Nyíregyháza. These investments, however, were connected to the offset contract of Grippen fighters, so they can not be taken as results of 'independent' business decisions. Altogether, between 1991 and 2007, the company invested around HUF 75 billion (around EUR 300 million) in Hungary, employing at the end of $2007,4,800$ workers. ${ }^{12}$ The company belonged to the group of top companies in Hungary: it was the I8th biggest employer in 2006, 35th according to its annual sales, and the 19th biggest exporter (based on data of HVG, 5 January 2008, pp. 52-7I).

The information is very scarce about fiscal, financial and other incentives offered to Electrolux Lehel. The following information could be collected in this regard. For building the Nyíregyháza factory in the industrial park, the company received a two-year holiday from local tax and reduction in the following two years. While information is not available, it is probable, that for its investments and research and development activities, the company could receive reductions from the profit tax. Information is available from a previous study (Antalóczy and Sass, 2002), in which we collected incentives given to companies in Hungary for one year (1999), comparing pre-tax and after-tax profits. According to that list, the Electrolux Lehel Company was among those receiving a significant tax reduction.

Impacts on the local economy can take many forms, as is obvious from the literature. Due to the lack of information, here we concentrate on three channels through which the company has significant impact on the host economy, and for which some data are available.

One of these channels can be its impact on the performance of the acquired company. Productivity in the domestic affiliate of Electrolux grew at a very high pace, sales especially, although exports also grew very quickly. Expansion of capacities and further investments were financed partly by the parent company, and partly from reinvestments of profits of the affiliate. Number of employees has been gradually reduced from 4,500 in 1991 to $3,500-3,600$ by 2005 . However, through employment in suppliers, an additional 2,500 workers' employment is provided by Electrolux Lehel. ${ }^{13}$ Moreover, due to further investments, the overall number of employees jumped back to 4,500 by $2007 .{ }^{14}$ 
As Caves (2007) puts it 'The gains that host countries enjoy from taxing foreign investment have been sorely neglected in debates over MNEs.' The second channel through which the local economy can be impacted upon is payment of taxes. The Electrolux Lehel Company is a key taxpayer. The company is among the top taxpayers in the Jász-Nagykun-Szolnok county, and its largest company based on net sales and own capital (Heröcziné, 2006). In 2007, it paid more than HUF 6 billion (more than EUR 24 million) in taxes, of which HUF 870 million (approximately EUR 3.5 million) were local taxes. ${ }^{15}$

A third channel, through which the company's impact on the local economy could be traced, is the 'use' of local suppliers. The Electrolux Lehel Company operates a large network of domestic suppliers, and partly due to that, reached an exceedingly high share of local value added. In the case of certain goods, for example vacuum cleaners, more than $70 \%$ of the total value of the final product is produced by local suppliers, and overall, the share of local suppliers is between 40-50\%. This share is among the highest in Hungary (Bakács, Czakó and Sass, 2006). The reason for this high share of local suppliers lies in many, in some cases interrelated, factors. At the time of privatization, most of the parts and components were produced inside the company, and there was a relatively limited network of suppliers. A few years after privatization, starting from 1996-1997, the production of certain parts and components, not belonging to core activities, started to be outsourced to local suppliers. Because of the technological characteristics of the sector (high specific transport costs for the majority of parts and components), the management looked for local suppliers. This outsourcing process provided the base for the establishment of a large local supplier network. The process itself was well timed from the point of view of local companies: foreign suppliers did not move to Hungary at that time to carry out these activities, which can be proven by the fact that the number of foreign-owned local suppliers is very low. The process was helped by the strong local tradition in machinery, metalworking and plastics industry, and related to these, the presence of strong local human and physical capacities. Because the affiliate was relatively independent in selecting its suppliers, and because of sector specificities (high specific transport costs, seasonality, need of quick reactions to changes in demand and tastes, and the need to reduce warehousing costs), this resulted in a relatively large number of local suppliers.

Indigenous firms may benefit from the presence of a foreign-owned firm in many ways. Thus, becoming a supplier of an affiliate of a MNC for a domestic company means not only the 'simple' possibility of selling products to another company, but there may be additional advantages. Through vertical linkages MNCs may increase the productivity of their domestic suppliers, for example by providing technical assistance to enable suppliers to raise the quality of the 
required spare part or component, or provide high quality standards for local inputs and thus induce technology upgrading in the indigenous company (Görg and Greenaway, 2004). According to Lall (1980), local affiliates of MNCs can contribute to raising the productivity and efficiency of local companies in less developed countries in many ways: by helping prospective suppliers to set up their own production facilities, by providing technical assistance and/or advice on raising the quality of products, on organizing and managing production, by reducing the price or increasing the availability of raw materials and intermediary products for production by helping the suppliers in buying them (for example, by organizing common purchase of inputs for a group of suppliers), and by helping suppliers to find other customers ${ }^{16}$ In the case of Electrolux Lehel, (potential) suppliers are, for example, helped by technical advise, by common purchase of inputs (thus attaining lower prices), by selling the machinery of the company to (potential) suppliers during the outsourcing process, by carrying out common development and adaptation activities with the suppliers. This latter even elevates the relationship between Electrolux-Lehel and its suppliers to a higher level. It also helps from the point of view of networking and clustering, that Electrolux Lehel requires its suppliers to rely on more than one source, namely, the share of Electrolux Lehel can not dominate in total sales of a supplier. On the other hand, in the supplier strategy of Electrolux Lehel, there must be at least two suppliers of a certain component or part. However, an element of instability is introduced from the point of view of the suppliers due to the fact that Electrolux Lehel concludes supplier contracts for relatively short time periods. There were also cases when the Electrolux Lehel Company got rid off established local suppliers from one year to another, causing big losses to the affected SMEs.

\subsubsection{Nokia Komárom Ltd.}

Nokia Komárom Ltd. was established in 1999 through a greenfield investment by the Finnish corporation Nokia, which is the biggest producer of mobile phones and mobile network appliances in the world. The most important location factors were the following: geographical proximity to the main European markets, good experiences with the country (previous production plant), and competitive wages. The city of Komárom itself competed with other Hungarian towns, and it was chosen on the basis of logistics aspects (on the Budapest-Vienna motorway and railway, closeness to the border with Slovakia), large stock of suitably skilled workers and closeness to universities. Up till now, Nokia invested around EUR 250 million in Komárom.

The Hungarian affiliate is one of the centers of mass production of mobile phones. At the end of 2008 , there were ten affiliates in nine countries. On the 
basis of production capacities, the Hungarian affiliate can be the third biggest after the Indian and Finnish ones. ${ }^{17}$ According to our estimation, the Hungarian affiliate represented around one tenth of the global revenues of Nokia Corporation (based on Nokia Corporation Annual Report and HVG TOP 500, 3 January 2009). On the basis of its net sales and exports, the Nokia Komárom company has become the third largest company of Hungary starting from around 2005 (HVG TOP 200, 2008, 5 January 2008 and TOP 500 2009, 3 January 2009). Its exports represented more than $7 \%$ of total Hungarian exports in 2007. It has a high export intensity; its export/sales ratio is $98 \%$ (own calculations based on HVG TOP 500, 3 January 2009). Its main export markets are Europe, the Far East and Africa. The company employed more than 3,000 workers in 2008. Together with 'rented' employment and service providers, this number is more than $6,000.90 \%$ of workers are employed in production and 10\% carries out management and engineering activities.

The company received substantial incentives from the government - similar to other big projects. At the end of the I990s, as we saw, Hungarian FDI promotion was not EU-conform, though it was transparent and normative. Incentives were connected to the volume of the investment, number of employees, and the location of the plant. Nokia received a ten-year tax holiday from profit tax and a five-year tax holiday from local tax. In the Industrial Park of Komárom, the local government provided the area and infrastructure free of charge for the investment. In the framework of various incentive schemes, the company received an additional state aid of HUF 200 million.

Nokia was the first investor in the Industrial Park of Komárom, and it was followed by various suppliers of the company. Part of them was encouraged by Nokia, others by the prospects of selling parts and components to Nokia. This allowed Nokia to reduce logistics risks to the minimum and to 'manage' supplies. There are II suppliers, all of them in foreign ownership (Finnish, Japanese, US, Swedish, Korean and Taiwanese), which altogether employ almost I0,000 additional workers. They are all global partners of Nokia, fulfilling very strict quality requirements. The increasingly intense competition induces Nokia to cooperate more closely with suppliers and to ask for ever greater production, technology and transport flexibility from them. However, in certain cases Nokia provides them with technical help, advice and support for technology development plans.

The investment of Nokia changed the economic landscape of the city and the county. It became the leading location in FDI attraction, industrial output, investment and exports. It changed the structure of employment in the region, the wealth of locals and local governments. The unemployment rate went down from $17.5 \%$ in 1993 to below $6 \%$ (pre-crisis). Its employment impact affected a larger re- 
Table 7.1 Foreign investments in manufacturing in Komárom, mid-2008

\begin{tabular}{|c|c|c|c|c|c|}
\hline $\begin{array}{l}\text { Name of } \\
\text { company }\end{array}$ & Activity & Nationality & $\begin{array}{l}\text { Year of } \\
\text { establish- } \\
\text { ment }\end{array}$ & $\begin{array}{l}\text { Entry mode and } \\
\text { share of foreign } \\
\text { ownership }\end{array}$ & $\begin{array}{l}\text { Connected } \\
\text { to Nokia? }\end{array}$ \\
\hline $\begin{array}{l}\text { Nokia } \\
\text { Komáromi } \\
\text { Ltd.. }\end{array}$ & $\begin{array}{l}\text { Production of mobile } \\
\text { phones }\end{array}$ & Finnish & 1999 & $\begin{array}{l}\text { Greenfield, } \\
100 \%\end{array}$ & - \\
\hline $\begin{array}{l}\text { Perlos Plastics } \\
\text { Ltd.. }\end{array}$ & $\begin{array}{l}\text { Production of } \\
\text { electronics and } \\
\text { telecom part and } \\
\text { components }\end{array}$ & Finnish & 2000 & $\begin{array}{l}\text { Greenfield, } \\
100 \%\end{array}$ & Yes \\
\hline Excel Ltd.. & $\begin{array}{l}\text { Production of } \\
\text { electronic products }\end{array}$ & Finnish & 2000 & $\begin{array}{l}\text { Greenfield } \\
\text { (inside Nokia's } \\
\text { site) } 100 \%\end{array}$ & Yes \\
\hline Schwöler Ltd. & $\begin{array}{l}\text { Production of } \\
\text { pelmets }\end{array}$ & $\begin{array}{l}\text { Austrian- } \\
\text { Hungarian }\end{array}$ & 2002 & Greenfield, n.d. & No \\
\hline $\begin{array}{l}\text { Sunarrow } \\
\text { Hungary Kft }\end{array}$ & $\begin{array}{l}\text { Production } \\
\text { of electronic } \\
\text { components }\end{array}$ & Japanese & 2002 & $\begin{array}{l}\text { Greenfield, } \\
100 \%\end{array}$ & Yes \\
\hline $\begin{array}{l}\text { SAVCOR } \\
\text { Komárom Ltd. }\end{array}$ & Metalworking & Finnish & 2003 & $\begin{array}{l}\text { Greenfield, } \\
100 \%\end{array}$ & Yes \\
\hline $\begin{array}{l}\text { Kayser } \\
\text { Automotíve } \\
\text { Hungária Ltd. }\end{array}$ & $\begin{array}{l}\text { Production } \\
\text { of electronic } \\
\text { components for cars }\end{array}$ & German & 2003 & $\begin{array}{l}\text { Greenfield, } \\
100 \%\end{array}$ & No \\
\hline $\begin{array}{l}\text { Foxconn } \\
\text { Hungary Ltd. }\end{array}$ & $\begin{array}{l}\text { Production } \\
\text { of electronic } \\
\text { components }\end{array}$ & Taiwanese & 2003 & $\begin{array}{l}\text { Greenfield, } \\
100 \%\end{array}$ & Yes \\
\hline ICHIA Ltd. & $\begin{array}{l}\text { Production } \\
\text { of electronic } \\
\text { components }\end{array}$ & Taiwanese & 2004 & $\begin{array}{l}\text { Greenfield, } \\
100 \%\end{array}$ & Yes \\
\hline $\begin{array}{l}\text { RR Donellei } \\
\text { Hungaria Ltd. }\end{array}$ & Printing activity & US & 2004 & $\begin{array}{l}\text { Greenfield, } \\
100 \%\end{array}$ & Yes \\
\hline $\begin{array}{l}\text { Hansaprint } \\
\text { Ecender Ltd. }\end{array}$ & Printing activity & $\begin{array}{l}\text { Swedish- } \\
\text { Finnish }\end{array}$ & 2005 & $\begin{array}{l}\text { Greenfield, } \\
100 \%\end{array}$ & Yes \\
\hline $\begin{array}{l}\text { MIRAE } \\
\text { Hungary Ltd. }\end{array}$ & $\begin{array}{l}\text { Production of plastic } \\
\text { products }\end{array}$ & Korean & 2005 & $\begin{array}{l}\text { Greenfield, } \\
100 \%\end{array}$ & Yes \\
\hline $\begin{array}{l}\text { STORA ENSO } \\
\text { Packaging } \\
\end{array}$ & $\begin{array}{l}\text { Production of } \\
\text { packaging material }\end{array}$ & Swedish & 2005 & $\begin{array}{l}\text { Greenfield, } \\
100 \%\end{array}$ & Yes \\
\hline $\begin{array}{l}\text { LK Products } \\
\text { Ltd. }\end{array}$ & $\begin{array}{l}\text { Production } \\
\text { of electronic } \\
\text { components for } \\
\text { mobile phones }\end{array}$ & Finnish & n.d. & $\begin{array}{l}\text { Greenfield, } \\
100 \%\end{array}$ & Yes \\
\hline
\end{tabular}

Source: Local government of Komárom 
gion: not only the city and the county, but even the neighboring parts of Slovakia, from where employees are commuting daily (about $35 \%$ of the employees come from Slovakia).

In terms of taxes, the ten-year profit tax holiday expired in 2009. On the other hand, local taxes have been paid by the company in the last four years, and according to the representative of the local government, Nokia is the biggest taxpayer of the city. Understandably, during its operations, the company paid all other (for example, wage related) taxes. Overall, in terms of tax payments, the contribution of the company is quite limited, compared to the Lehel Electrolux case, for example.

As far as the spillover effects of the investment are concerned, one of its most important channels is the use of local supplies. In that respect Nokia Hungary represents a case when the greenfield foreign investment 'attracts' its traditional suppliers to the new site. The first tier suppliers are partners of Nokia on the basis of global agreements, all around the world. Thus the Komárom Industrial Park is basically a closed 'network' of companies, which operates as an island in the area. No Hungarian company could get into this system or network as a first or second tier supplier. ${ }^{18}$ Nokia started to organize the entry of its second tier suppliers in the mid-200os, into a new industrial park close to Komárom. Besides its suppliers in Komárom Industrial Park, another ten suppliers are operating in Hungary, among these there are a few Hungarian companies which supply Nokia with less complex products (like batteries). Besides these, services provided in the industrial park by Hungarian-owned companies (including catering, waste management, transport of persons, gardening, and security) are used by Nokia. It indirectly impacted upon the development of its larger surroundings. In the city of Komárom for example, since around 2002, a quicker development of services can be experienced, and due to the growth in purchasing power, a large supermarket is opened. Nokia has concluded cooperation agreements with universities and secondary schools with the aim of ensuring future employment. Due to the relatively large employment from the other side of the border, cooperation between the two local governments has improved; they center their common development strategy plan on the activities of the local Nokia affiliate.

However, besides the positive impacts, it is still true that companies in the industrial park function as an island, separated to a great extent from the local economy. There is little information about the company and the power of the MNC and the local government cannot be compared. Locals feel defenseless at the mercy of a big MNC.

The two case studies indicate different types of local impacts of the supported companies. In Electrolux's case, followers' FDI (in terms of traditional suppliers investing in Hungary) is negligible, follow-up investments by the company 
are significant (besides capacity extensions, establishing a completely new plant in Nyíregyháza). Moreover, there is a substantial increase in the number of local suppliers and local value added, reaching a high level even in international comparison. In the case of Nokia, while the volume of FDI is increased through investments by traditional suppliers and by additional investments of Nokia, in terms of local contacts, this project remains an 'island' in the local economy. While their direct impact for example in terms of tax generation, increased productivity and export is similar, their indirect impact on the local economy differs quite substantially. FDI policies seem to influence the local impact only to a very limited extent, sector specificities including 'networkedness' (the degree of value chain integration) play a determining role. Our illustration calls the attention to a paradox: attracting state of the art technology usually goes together with the globally integrated nature of the new affiliate which may result in a very low level of local linkages. On the other hand, 'less high-tech' affiliates may be more prone to create (or maintain) local linkages and may become more embedded in the local economy.

\subsection{The impact of the crisis}

Completely new circumstances have emerged for the Hungarian (and other countries') FDI policies starting from the second half of 2008. Strikingly low invested amounts and high repatriations show the lack of 'free' capital, available for direct investments in the region. While the focus of the Hungarian economic policy still seems to be on FDI, responses and reactions of the government do not reflect the new realities. They still try to attract investments in the same (pre-crisis) sectors, with the same tools and mechanisms.

As we saw, Hungary is very 'dependent', even in international comparison, on the performance of FIEs. Moreover, links of these companies with the domestic sector remains below the expectations, thus they could not act as a kind of 'pulling' factor for domestic enterprises for various reasons. Moreover, FDI in Hungary is concentrated in those manufacturing sectors, which are especially hard hit by the crisis: automotive and electronics. Some companies close down their operations in Hungary completely; many of them reduce their operating capacities. Moreover, they tend to repatriate more profits, according to the latest balance of payments information, in order to compensate their home/parent companies' losses. Fiscal stimulus programs of developed countries, one (explicit) aim of which is to keep investments and production at home, are also not favorable for affiliates producing in Hungary. Hungary's special situation, where domestic economic policy mistakes and postponement of restructuring of the 
fiscal system deepen the impacts of worldwide recession, act also as a deterrent to FDI. On top of that, lack of investable capital induces more acute competition for resources, including a sharper incentive competition, in which Hungary's means, compared to its most important competitors, are very limited. In these circumstances, a complete reappraisal and restructuring of FDI (and overall economic) policy would be needed. In the absence of that, we see only the competitiveness of the country gradually decreasing.

\subsection{Conclusion}

Hungary was the first to open up to FDI in the EEC region, forced partly to do so by its heritage from the socialist period and by economic and political circumstances. The country started to establish the legal framework already in the I970s, the regulatory framework at the end of the 1980 s. It was the first to start to privatize by selling companies to foreigners on a large scale. In Hungary, the domestic accumulation of capital was minimal, thus the main engine behind economic changes and growth was FDI. The country operated an FDI policy, which became increasingly transparent and normative and gradually gave equal treatment to all investors, foreign and domestic alike. The incentive policy became growingly complex, and reflected to a growing extent the priorities of the government. It tried to target investors, which establish more complex activities in Hungary. Recognition soon dawned of the lower than expected linkages and connections of affiliates with the local economy, which hindered the realization of the potential beneficiary impacts of MNCs on the local economy. Hungarian FDI policy very early tried to address this problem with various supplier programs. While in volume terms, Hungarian FDI policy can be evaluated as successful; in terms of the level of local embeddedness of affiliates it could not reach its aim.

\section{Notes}

* Senior research fellow, Finance Research Ltd., email: antaloczy.katalin@helka.iif.hu

** Senior research fellow, Institute of Economics of the Hungarian Academy of Sciences, email: sass@econ.core.hu

*** Senior research fellow, Institute for World Economics of the Hungarian Academy of Sciences, and professor, Debrecen University, email: mszanyi@vki.hu

I Data complying with the OECD/IMF recommendations are available for the year 1995 and onwards, and data on reinvested earnings have been published since I998.

2 Some years are exceptions due to larger privatization-related inflow.

3 Based on the data presented in UNCTAD, 2008. 
4 However, registered countries of origin do not always correspond to the country of the parent of the multinational company because in many cases foreign affiliates realize the investments due to tax, strategic, geographical or cultural reasons. This is the case for some important Hungarian investments (for example German Siemens invested through its Austrian subsidiary, the US GM and IBM through its German and the Italian Feruzzi through its Belgian or French affiliate). Accordingly, official statistics may underestimate the share of those countries, which are registered homes of big multinationals, especially that of the US (and maybe German) investors.

5 Data are somehow distorted, because many companies have their headquarters registered in Budapest, and conduct (production) operations in plant(s) in the countryside (see for example Antalóczy and Sass, 2005).

6 A region can be a group of countries, a country or inside a country; it is the geographic area inside of which the multinational wants to invest.

7 After a five-year break, in 2003 the privatization process has been restarted, putting up for sale state-owned banks and companies. However, the share of privatization-related FDI in total FDOI has never again reached the pre-I998 level.

8 Details of the program will be presented in the next section.

9 Company cases, for example IBM's choice of the Czech Republic over Hungary due to more generous incentives are presented in Antalóczy and Sass (2002).

Io Usually companies deny even the limited role of incentives in influencing their investment decisions. The reason why in this questionnaire survey companies 'admitted' that incentives are important for them, was that it was taken in a historical moment: before the EU accession of the country, when it seemed like these companies would be 'ripped off' of the incentives.

I I The choice of these two companies can be explained by the availability of data and information. Both companies are of Scandinavian origin, which may help reducing the home country effect.

I2 http://www.fn.hu/cegek/20081008/3_5_milliardos_electrolux_beruhazas/.

I 3 http://www.partnerinfo.eu/text.aspx?id=ELEKTROLUX.

I4 http://www.fn.hu/cegek/20081008/3_5_milliardos_electrolux_beruhazas/.

I5 http://www.fn.hu/cegek/20081008/3_5_milliardos_electrolux_beruhazas/.

I6 The empirical literature is lacking of inconclusive evidence for the existence of this kind of spillovers, partly due to methodological and data shortcomings. (Girma, Görg and Pisu, 2007) However, there are a few papers that indicate the importance of vertical (rather than horizontal) linkages, see for example Javorcik (2004).

I7 Annual Report 2008, www.nokia.com.

I8 See Table I.

\section{List of references}

Antalóczy K. and M. Sass (2002) 'Greenfield investments in Hungary', Transnational Corporations 200I(3), 39-60.

Antalóczy K. and M. Sass (2002) A nagybefektetői adókedvezmények közvetlen és tovagyürüzö hatásai a befektetésekre és az üjra-befektetésekre (The direct and spillover impact of tax allowances for big investors on investments and re- 
investments), Manuscript, prepared for the Ministry of Economics, Financial Research Insitute, March 2002.

Antalóczy K. and M. Sass (2003) 'Befektetésösztönzés és Magyarország csatlakozása az Európai Unióhoz' (FDI incentives and Hungary's EU accession), Külgazdaság XLVII, 2003(4), 4-29.

Antalóczy K. and M. Sass (2005) 'A külföldi működőtőke-befektetések regionális elhelyezkedése és gazdasági hatásai Magyarországon' (Regional distribution of foreign direct investments and their economic impacts in Hungary), Közgazdasági Szemle LII, 494-520.

Antalóczy K., M. Sass and G. Varga (2006) Stratégia megalapozása és kidolgozása a hazai gazdaság regionális egyenlőtlenségeinek csökkentésére, versenyképességének javítására, a sikeres uniós integrációra (Elaborating a strategy for reducing regional disparities in Hungary, improving the regions' competitiveness, and successful integration in the EU), Pénzügykutató Rt, Mimeo, Budapest.

Bakács A., V. Czakó and M. Sass (2006) 'Beszállítók és hálózatosodás: az Electrolux-Lehel Kft. Példája' (Suppliers and networking: the case of Electrolux Lehel company), Külgazdaság L. July-August, 7-8, 44-59.

Bellak, C., M. Leibrecht and R. Römisch (2005) 'New Evidence on the Tax Burden of MNC Activities in Central- and East- European New Member States', Discussion Paper 2, www.wu-wien.ac.at/sfb-itc.

Bobonis G.J. and H.J. Schatz (2007) 'Agglomeration, Adjustment, and State Policies in the Location of Foreign Direct Investment in the United States', The Review of Economics and Statistics 89(I), 30-43.

Bosco M.G. (200I) 'Does FDI Contribute to Technological Spillovers and Growth? A Panel Data Analysis of Hungarian Firms', Transnational Corporations IO(I), 43-68.

Campos N.F. and Y. Kinoshita (2002) 'Foreign Direct Investment as Technology Transferred: Some Panel Evidence from the Transition Economies', William Davidson Institute Working Paper 438, University of Michigan, Ann Arbor.

Caves R.E. (2007) Multinational Enterprise and Economic Analysis, Third Edition, Cambridge University Press, Cambridge.

Charlton A. and N. Davis (2006) Does investment promotion work?, London School of Economics, Mimeo, London.

Clark W.S. (2000) 'Corporate Tax Incentives for Foreign Direct Investment (Main Types, Potential Effects and Design Considerations)', Paper, prepared for the Seminar on Foreign Direct Investment and Privatization Policies, Vienna, 5-9 June.

Csáki G. (200I) 'Some Critical Issues of Economic Transition', in G. Csáki and G. Karsai (eds.) Evolution of the Hungarian Economy 1848-2000, Volume III, 
Hungary: From Transition to Integration, 171-405, Columbia University Press, New York.

Damijan J.P., B. Majcen, M. Rojec and M. Knell (200I) 'The Role of FDI, R\&D Accumulation and Trade in Transferring Technology to Transition Countries: Evidence from Firm Panel Data for Eight Transition Countries', Working Paper 10, Institute for Economic Research, Ljubljana.

Damijan J.P., M. Knell, B. Majcen and M. Rojec (2003) 'Technology Transfer Through FDI in Top-Io Transition Countries: How Important are Direct Effects, Horizontal and Vertical Spillovers?', Working Paper 549, William Davidson Institute, University of Michigan, Ann Arbor.

Dunning J.H. (1993) Multinational Enterprises and the Global Economy, AddisonWesley, Wokingham.

Ellison D. (2007)'A Political Economy of Subnational Regionalism in a Supranational Context: The case of Hungary', Paper, 48th Annual Conference, International Studies Association, Chicago.

Fink Ph. (2006)'FDI-led Growth and Rising Polarisations in Hungary: Quantity at the Expense of Quality', New Political Economy II(I), 47-72.

Girma S., H. Görg and M. Pisu (2007) 'Exporting, Linkages and Productivity Spillovers from Foreign Direct Investment', CEPR Discussion Paper 6383, CEPR, London.

GM (200I) Magyar beszállitók helyzete az autóipari és elektronikai multinacionális cégeknél (The position of Hungarian suppliers in vehicle industry and electronics MNCs), Ministry of the Economy, Mimeo, Budapest.

Gorodnichenkou Y., J. Svejnar and K. Terrell (2007) 'When does FDI Have Positive Spillovers? Evidence from 17 Emerging Market Economies', Michigan Ross School of Business Working Paper 1101, University of Michigan, Ann Arbor.

Görg H. and D. Greenaway (2004) 'Much Ado about Nothing? Do Domestic Firms Really Benefit from Foreign Direct Investment?', World Bank Research Observer 19, I7I-197.

Halpern L. and B. Muraközy (2007) 'Does distance Matter in Spillover?', Economic of Transition I5(4), 78I-805.

Harding T. and B. Smarzynska-Javorcik (2007) 'Developing Economies and International Investors: Do Investment Promotion Agencies Bring them Together?', CEPR Discussion Paper 6418, London.

Hassett K.A. and R.G. Hubbard (1998) 'Are Investment Incentives Blunted by Changes in Prices of Capital Goods?', International Finance I, I03-I25.

Herőcziné Bodori Éva (ed.) (2006) TOP 50 - J-NK-Szolnok Megye 50 legjelentösebb cége (Top 50 companies of Jász-Nagykun-Szolnok County) APEH, J-NK-Szolnok Megyei Igazgatóság - J-NK-Szolnok Megyei Kereskedelmi és Iparkamara, Szolnok. 
Hubert F. and N. Pain (2002) Fiscal Incentives, European Integration and the Location of Foreign Direct Investment, National Institute of Economic and Social Research, March, London.

Hunya G. and M. Sass (2005) Coming and Going: Gains and Losses from Relocations Effecting Hungary, WIIW Research Reports 323, November 2005, WIIW, Vienna.

ITDH (2002) Automotive Industry in Hungary 2002. www.itd.hu

ITDH (2007) Beszállitói Program Hálózatépitési Modul Stratégiája (Supplier Program Network-building Module Strategy), February, Budapest.

Javorcik-Smarzynska B. (2004) 'Does Foreign Direct Investment Increase the Productivity of Domestic Firms? In Search of Spillovers through Backward Linkages', American Economic Review 94(3), 605-627.

Javorcik B. and M. Sparateanu (2003) 'To Share or Not To Share: Does Local participation Matter for Spillovers from Foreign Direct Investment?', Policy Research Working Paper Series 3118, The World Bank.

Knell M. (2000) 'FIEs and productivity convergence in Central Europe', in G. Hunya (ed.) Integration through Foreign Direct Investment. Making Central European Industries Competitive, 28-49, WIIW, Vienna.

Kosová R. (2005) Do Foreign Firms Crowd Out Domestic Firms? Evidence from the Czech Republic, University of Michigan Business School, PhD Dissertation.

Lall S. (1980) 'Vertical Interfirm Linkages in LDCs: An Empirical Study', Oxford Bulletin of Economics and Statistics 42, 203-226.

Lipsey R.E. (2006) 'Measuring the Impacts of FDI in Central and Eastern Europe', NBER Working Paper Series 12808, NBER, December 2006.

Mah J.S. and D. Tamulaitis (2000)'Investment Incentives in the Central and Eastern European Transition Economies', The Journal of World Investment I(I), 225-24I.

Morisset J. and K. Andrews-Johnson (2004) 'The Effectiveness of Promotion Agencies at Attracting Foreign Direct Investment?’, Foreign Investment Advisory Service (FIAS) Occasional Paper 16, World Bank, Washington, DC.

MVKHT (2000) Az 1999, évi beszállitói célprogram hatásvizsgálata (Impact study of the 1999 Supplier Target Program), Magyar Vállalkozásfejlesztési Kht, MIMEO, Budapest.

Nokia Corporation (2009) Annual Report, www.nokia.com/NOKIA_COM_I/ About_Nokia/Financials/form20-f_o8.pdf.

Novák Cs. (2003) 'A külföldi müködőtőke és a technológiai tovagyürüzés Magyarországon' (FDI and technology spillovers in Hungary), MTA VKI Mübelytanulmányok, 50, October.

OECD (1989) International Investment and Multinational Enterprises: Investment Incentives and Disincentives. Effects on International Direct Investment, OECD publications, Paris. 
Páczi E. and J. Eörsi (1993) Környezetvédelem és privatizáció (Environment protection and privatisation), Európa Fórum 12, 67-78.

Pavlinek P. (2004) 'Regional Development Implications of Foreign Direct Investment in Central Europe', European Urban and Regional Studies II(I), 47-70.

Réthi S. (200I) A háttéripar szerepe az átrendezödés folyamatában (The role of background industry in the restructuring process), Floreno Kft., Mimeo, Budapest.

Sass M. (2005) 'Tőkevonzás és privatizáció. A visegrádi országok példája' (Attracting FDI and Privatization: The Case of the Visegrad Countries), Gazdaság és Statisztika 6, 3-20.

Sass M. (2003) 'FDI in Hungary: The First Mover's Advantage and Disadvantage', European Investment Bank Papers 9(2), 62-90.

Schoors K. and B. van der Tol (2002) 'Foreign Direct Investment Spillovers within and between Sectors. Evidence from Hungarian Data', Ghent University Working Paper 157, Ghent University.

Szanyi M. (2002) 'Spillover Effects and Business Linkages of Foreign-Owned Firms in Hungary', Hungarian Academy of Science Working Paper 126, Budapest.

Taylor Ch. (2000) 'The Impact of Host Country Government Policy on US Multinational Investment Decisions', World Economy 23(5), 635-648.

Út-Eurocon Bt. (200I) A bazai tulajdonú vállalatok beszállitóvá válása (Becoming a supplier of domestically owned firms,) Mimeo, Institute for World Economics, Budapest.

Wells L.T. and A.G. Wint (2000) 'Marketing a Country', Occasional Paper 13, Foreign Investment Advisory Service World Bank, Washington, DC. 



\title{
8 Policies and institutions on multinational corporation-small and medium enterprise linkages
}

\author{
The Brazilian case
}

Delane Botelho* and Mike Pfister**

\section{I Introduction}

What can host countries expect from foreign corporations entering their market? Effects such as increased employment and exports certainly are important, but the development of domestic industries through the potential positive spillovers of multinational corporations' (MNCs) activities, notably via the avenues of transfer of technological and management expertise and sustained economic growth, are among the foremost expectations. Social and economic development depends on several factors, such as investments from the private and public sector in education, health, safety, infrastructure, and technological innovation, and private companies. MNCs as well as local Small and Medium Enterprises (SMEs) have a crucial role to play in this regard. However, having companies set up in a given area in itself is not a guarantee for fostering development. A MNC, for instance, may be attracted to a developing country due to tax incentives, lower labor costs and easy access to natural resources only, whilst importing qualified labor and buying from foreign suppliers and barely contributing to local development.

One important source of development and technology in-flow in developing economies is related to the externalities resulting from the Business Linkages (BL) that local suppliers can forge with the foreign affiliates of MNCs. BLs between MNCs and SMEs can allow small local producers to benefit from an exchange of relevant information and technical knowledge, promote production efficiency, productivity growth and market diversification, among other benefits. Also, there is evidence (UNCTAD, 2005) that the more MNCs are intertwined with local companies through supplier or other linkages the more likely they are to maintain their operations in the country in the long term. While MNCs have strategic interests in forging links with domestic suppliers, public policies and institutions (such as Investment Promotion Agencies - IPAs), can play a crucial 
role in promoting such linkages (UNCTAD, 200I). Assuming that the promotion of linkages is part of the industrial policy framework, and that they can be promoted by IPAs on the federal as well as on the state level, the aim of this chapter is to evaluate the current situation of such policies and programs of BL in Brazil, the largest recipient and source of foreign direct investment (FDI) in Latin America. The chapter aims to: I) analyze actions and programs developed by public and private institutions to foster BL in Brazil; 2) identify the participants' benefits from such actions and programs; and 3) highlight the opportunities for the public sector in promoting BLs.Our empirical analysis is based on several research trips and more than forty semi-structured interviews with experts from different organizations in Brazil and in Europe. The units of analysis in this chapter refer to the programs that foster BLs in Brazil, and key representatives of the following organizations were interviewed from May 2007 to July 2008: IPAs, to comprehend how the development funding agencies work and the extent of their relationship with the public authorities; institutions that promote BLs, including industry associations of eight states in Brazil, representatives of Projeto Vinculos (states of Pernambuco, Bahia, Ceará, Amazonas and São Paulo), consulting firms, representatives of Supplier Development Programs (SDPs) in four states; representatives of the state and federal government, including the Ministry of Development, Industry and Foreign Trade (MDIC) and the Brazilian Trade and Investment Promotion Agency (APEX); and managers from MNCs and SMEs acting in different sectors (chemical, electronics and mining) involved in linkage programs for at least three years. Our research was motivated by the growing attention in the literature (Ivarsson and Alvstam, 2004) given to the relation between economic development levels and the ability of companies and countries to absorb and disseminate competencies. As BLs may promote local development, they may be of interest in the perspective of the state government, as of an economic regulation agent and social development supporter, especially when suppliers from well-developed areas or from overseas take over the role of local ones.

The chapter is structured as follows: this introduction presents the purposes, relevance and method of the empirical work. We move on to present the theoretical background to the research emphasizing the buyer-supplier relationship. Then we describe the Brazilian investment and SME environment and efforts to develop companies by implementing public policy programs. The chapter concludes by discussing the implications of our results for public policy and development, especially in emerging markets. 


\subsection{Conceptual framework of business linkages}

Linkages are defined as non-equity based relationships between foreign affiliates and domestic firms that have the potential for spillovers (Kennel, 2007). They may be horizontal, occurring through competition effects; collaborative, with domestic partners for strategic, technological or managerial purposes or vertical, with domestic suppliers, agents or customers, licensees or franchises. Horizontal linkages create the competition effect that can prompt innovation, efficiency and technical improvements in domestic firms. Collaborative linkages involve affiliate-domestic firm alliance and other non-equity agreements involving an ongoing collaboration between firms. Vertical linkages generate demand for, and add to the supply of, locally produced goods and services. Foreign affiliates may contribute to raising the capabilities of domestic suppliers or customers by improving quality standards and efficiency of production, as well as providing assistance and resources relating to procurement, design, quality control, training, or market information. Those vertical linkages may be backward (with suppliers and subcontractors), which is the focus of this chapter, forward (with customers and agents) or contractual (with domestic franchisees and licensees) in nature (Kennel, 2007). Different types of affiliates can, via different linkage combinations, have different impacts on domestic firms. Typologies of BLs also include symmetry of linkages, considering that companies involved in linkages differ in terms of power resources (power relationships can be more or less symmetric, for example, depending on the size of suppliers and buyers). BLs are not only understood as business transactions among companies, but also include collective efforts by groups of companies aiming at creating competitive advantage, such as in the case of cluster initiatives (geographic concentrations of interconnected businesses, suppliers, and associated institutions in a particular field).

Some factors may explain the effort to develop backward linkages in host economies from a MNC perspective:

- The sector in which the foreign firms operate: foreign affiliates making standardized products with mature, non-proprietary technologies have many suppliers to choose from, and it is not necessary to develop special capabilities in any supplier. Where products are specialized and technologically advanced, on the other hand, affiliates tend to prefer in-house production or to retain relationships with a few selected strategic suppliers (UNCTAD, 200I).

- The firms' characteristics, such as I) selected entry mode: FDI taking the form of a joint venture leads to more local linkages than FDI in the form of a wholly owned subsidiary because investors that intend to spend more resources on 
building local relationships are more likely to choose a joint venture over a wholly owned subsidiary (although fully owned subsidiaries still need local linkages to operate in the local environment); 2) ownership form: local firms acquired by foreign MNCs, rather than subsidiaries or branches established as greenfield sites by the MNCs, tend to be more integrated into the local economy; 3) age of the plant, which may explain the embeddedness into the local economy; 4) autonomy of the affiliate: the greater, the more likely the affiliate is to try and identify local suppliers and to create relationships with them; size of the affiliate may also affect sourcing and linkages (UNCTAD, 200I; Giroud, 2006); 5) relationship between country of origin of the affiliate and local linkage formation, as proposed by Kennel (2007). In particular when MNCs are purely market-seeking, rather than aiming at exporting their products, they need a strong link with local companies to be able to adapt their products and eventually their research and development $(\mathrm{R} \& \mathrm{D})$ activities to the local conditions. Efficiency seeking firms normally have less incentive to form local linkages (although when they do they tend to be deeper).

Linkages may generate possible spillovers, such as externalities that arise when the entry or presence of foreign affiliates leads to improvements in the capacity, productivity or efficiency of domestic firms. Spillovers from FDI are typically classified into two categories according to their direction: horizontal (intraindustry spillovers), and vertical (interindustry spillovers) (Kneller and Pisu, 2007). Those spillovers are seen as having indirect development impact on host economies that can be attributed to the local industry as a result of the foreign affiliates' activities, so they are less documented in the linkage's literature. On the other hand, the direct developmental impact of MNCs in developing economies is well documented (UNCTAD, 2005), and includes tax revenues, exports, R\&D and employment generated by their affiliates. Even relatively very small companies with limited technological capabilities may in some cases benefit enormously from contracts with MNC or large buyers.

Giroud (2006) lists three key groups of factors conditioning the choice between host country and foreign sourcing. These are related to the MNCs' overall strategy and characteristics (as explained above), but also the host country policy framework and economic climate. Economic growth and the investment climate are important, as well as the quality of infrastructure, the capabilities and the size of local components industry. 


\subsection{Supplier development programs}

The buyer-supplier relationship is the subject of many discussions in business administration, such as in the areas of supply and value chains, operations and marketing. Industrial marketing, for example, seeks to understand how companies relate with one another when it comes to purchase and sale of products and which are the best strategies to make business ties profitable to both buyers and suppliers (Coviello and Brodie, 1998). The 'value chain' is a fundamental concept in this chapter, since it refers to the set of activities performed by an organization, from the relationship with suppliers, through the production and sale cycles, to the final distribution phase (Bornstein, 2003). According to the value chain theory, and from the perspective of buyer companies, improvements to the chain performance are expected to be possible only when long-term commitments are set with their key suppliers (Krause, 2007).While cluster initiatives, defined as concentrations of firms of a given sub-branch of industry within a delimited region in search for competitive advantage (Meyer-Stamer and Seibel, 2002), tend to have a local focus, the value chain concept tends to look at bigger spatial aggregates. Producers, and local clusters of producers, are usually part of a bigger value chain that encompasses the various transformation activities that ultimately lead to a final product. Therefore, an effort to connect local producers in developing economies to global markets often needs to involve lead firms in global value chains. MNCs generally have highly demanding consumers when it comes to quality and process control, acting in the world's most competitive environments (Shen, 2008). Such companies aim at reducing the number of suppliers and increasing their efficiency, and many SMEs are not always equipped to meet their demands. Therefore, many MNCs provide their own suppliers with managerial and technical training, developing programs to improve their overall capabilities in the value chain context. Such supplier development programs (SDPs) may allow companies to change a conflicting buyer-supplier relationship, based on power and bargain, into a partnership based on trust and cooperation (LangfieldSmith and Greenwood, 1998). The transfer of organizational abilities from the buyer to its supplier entails not only funds and resources, but also a dedicated organizational and governance structure to promote knowledge accumulation in the long run (Sako, 2004). Technology transfer not only includes the technical support and training activities, but also means informing and educating suppliers regarding product and process standards, and possibly assisting them in obtaining certification to meet global standards.

There are many studies on the buyer-supplier relationship in developing economies. Kumar and Bergstrom (2008), for instance, have analyzed a pattern of a long-term buyer-supplier relationship in South Africa, India, and Pakistan, 
concluding that the more developed the buying market was, the better the local supplier was treated by the MNC, and the stronger the relationship was between both. Jeppesen and Hansen (2004) depict the standards of management technology transfers from MNCs to their suppliers in developing economies, divided into three main patterns: I) identification of standards; 2) control and monitoring; and 3) technical collaboration. Such patterns portray a continuum ranging from low (determination of standards) to high (technical collaboration) interaction between companies. Client companies require products certified by internationally recognized authorities when determining standards, forcing suppliers' technological development. Control and monitoring fall under client-imposed standards, bringing several control mechanisms, such as the 'Michelin Certificate' provided to distributors that meet the quality standards required by such companies in Brazil. Technical collaboration occurs when large companies offer technical support to their suppliers so that they reach the standards required by the former, usually featuring the visit of specialized technical staff to the supplier to tighten the relationship between these two companies.

Ivarsson and Alvstam (2004) have also investigated the technology transfer in emerging markets, obtaining the following results: I) technology transfer is essentially based on BL, especially in the manufacturing sector (rather than in $R \& D$ ); 2) the assistance was not the same for each supplier the MNC supported, which proves that such benefits depend on suppliers' initial technological capacity, and their ability to learn and absorb technology; 3) long-term relationships based on trust are important to the collaboration and learning between companies, bringing benefits to suppliers, even in short-term relationships, while improving their technological capacity and exploring prospective markets.

While, in general, in developing economies the public sector is responsible for creating and developing SDPs and BLs, in developed ones the private sector is the most important promoter (Shen, 2008). But in Brazil there are examples of MNCs forging and investing in strategic linkages with suppliers: I) the French retailer Carrefour developed the program 'Guarantee of Origin', a product certification introduced in Brazil in 1999. The certificate ensures that products are produced and processed according to the company's global standards of quality, environmental and social responsibility at all stages. Since 'Guarantee of Origin' was introduced in the north of Brazil in 2005, many products that were formerly imported from richer states such as São Paulo are now produced locally with the same level of quality, and available at lower prices due to lower costs of distribution; 2) Bosch's Fit for Global Approach (FFGA) used to identify Brazilian suppliers and to bring them up to international standards in terms of product quality, delivery fidelity, management practice and client relations. The FFGA approach has been extended to Bosch's operations in China. 


\subsection{Public policies and the Brazilian effort to develop companies}

In Latin America, the state government has played an important role in the assurance of attracting FDI, reflected also in the recent nationalization processes of MNCs in Bolivia in 2006 (oil and gas fields) and in Venezuela in 2007 and 2008 (cement and telecommunications), that have reduced the companies' trust in investing in countries with greater commercial instability and/or high political risk. MNCs are important sources of income and development, but their employment generation potential is not proportional to their size. In 2008, although $420 \mathrm{MNCs}$ out of the world's top 500 had affiliates in Brazil, they accounted for only $2 \%$ of the jobs $(\mathrm{Ob}$ servatório Social, 2005). However, SMEs accounted for 17.2 million legal Brazilian jobs, compared to 8.8 million from large-sized companies (companies with over 500 employees in the industry sector or roo employees in the service sector) (Brazilian Micro and Small Business Support Service, 2008). Hence, it is not only a matter of attracting investment through the attraction of MNCs, but taking advantages of their role in the overall productive system. Most countries have national or local IPAs not only to attract more foreign investors, but also to focus on creating jobs, exports, and technological transfers related to the flow of investments. Some Brazilian IPAs include APEX (at the federal level), INDI (Minas Gerais Institute of Integrated Development) and INVESTE-São Paulo (Agency for Investments and Competition Promotion of the state of São Paulo). Brazilian governmental actions to attract investments started late in the I980s and early in the I990s. The country's structure to promote investments is complex, including federal institutions, IPAs from state development banks, IPAs arising from partnerships between government and private organizations, and nonprofit private organizations, as shown in Table 8.I.

Table 8.1 Examples of investments promotions agencies (IPAs) in Brazil (or development institutions with investment promotion roles)

\section{Federal institutions}

- Brazilian Trade and Investment Promotion Agency (APEX)

- System for the Promotion of Investments and Transfer of Technology to Companies (SIPRI)

IPAs arising from partnerships between government and private organizations

- Pernambuco Economic Development Agency (AD Diper)

- Minas Gerais Industrial Development Institute (INDI)
IPAs from state development banks

- Goiás Development Funding Agency (GoiásFomento)

- Rio Grande do Norte Development Funding Agency (AGN)

\section{Non-profit private organizations}

- Rio Grande do Sul Development Agency (Pólo-RS) 
MDIC is in charge of coordinating business promotion policies, a mandate that got reconfirmed in 2007 with the reinforcement of the Permanent Forum of Micro and Small Companies (created in 2000), through the Brazilian Statute for Micro and Small Companies. The Brazilian Constitution provides a differentiated treatment to those companies, enforceable by law, with actions applying to administrative, tax, social security and labor matters. Brazil has also the Micro and Small Company General Act to join the federal, state and municipal taxes levied on SMEs, reducing the tax rates in most cases. It also enables an easier registration of companies, access to credit and technology. In 2007, the Brazilian government enacted the first policy for the single payment of taxes from the three government levels (federal, state and municipal). In the country there is no difference in treatment of foreign companies, from a legal standpoint, in all matters relating to tax, labor rights, social security, or civil and commercial law, which helps to improve the investment climate. The regulation in place ensures the FDI access to the market and practically unrestricted national treatment in the area of goods. Such national treatment is firmly entrenched in administrative and legal practice. More than $13,000 \mathrm{MNCs}$ have established affiliates in the country.

There are numerous Brazilian institutions that seek to foster the improvement of the business environment and, indirectly, to promote BLs. Two important ones are: Brazilian Development Bank (BNDES) and Brazilian Micro and Small Business Support Service (SEBRAE). SEBRAE was created in 1972 as a nonprofit private entity aimed at fostering competitiveness and sustainable development of micro and SMEs. Its main income source is the mandatory contribution made by the private sector to the Brazilian Institute of Social Security (INSS). Development programs and IPAs, as potential sources of BL, are more efficient than the activities related to only providing financial incentives, and large companies' demand is not enough to set sustainable BLs, since building them also requires commitment from the relevant companies and the participation of all stakeholders: governments, IPAs, chambers of commerce, development funding banks, business associations, non-governmental organizations, media, universities, and research institutes.

The Brazilian overall scenario seems to create opportunities for BLs: the country has a great number of micro and small companies (in 2008 they were $99.2 \%$ of the total number of officially registered companies), and the Brazilian environment has been attractive to international companies as well: the last decade has been a period of unprecedented economic stability, when compared to the two previous decades, with inward FDI reaching USD 45.I billion in 2008, the highest amount since Brazil began keeping records in 1947 (Brazilian Central Bank, 2009). 


\subsection{Policy orientation for small and medium enterprises in Brazil}

The policy type to promote micro and small companies in Brazil is law. The first legal measure that established special treatment for micro and small enterprises was defined in 1984 by Law 7.256/84. It institutionalized the 'Estatuto da Microempresa', concerning the administrative, fiscal and social security system and labor rights. The General Law for Micro and Small Enterprises, starting in 2007, is the first national public policy (valid for all states in Brazil) that determines the unified payment of federal, state and municipal taxes. Nine different taxes are combined in a single payment, whose value is determined based on total revenues and activity sector. Also, other benefits are included: micro and small businesses have a preference on government bids up to $\mathrm{R} \$ 80,000$ (approximately USD 40,000) and do not have to pay export taxes. With this law in practice, it is expected that the time to open a new company decreases from 152 days to 15 days on average, as already is happening in some regions.

MDIC has the main responsibility in the country to coordinate the competitiveness policies to assist companies in general, although in practice other ministries, such as those of finance, science and technology and national integration, share such duties. The Permanent Forum of Microenterprises and Small Businesses, created in 2000 and strengthened in 2007 with the Estatuto Nacional da Microempresa e da Empresa de Pequeno Porte, is coordinated by MDIC, and its role is to guide and assist the formulation and coordination of the national policies that promote development for micro and small businesses. 48 institutions from the government and 47 entities that represent the interests of small business in Brazil participate in the forum.

The government fosters technological and scientific development through the Ministry of Science and Technology, although it is not yet experienced in promoting micro and SMEs (MSMEs)' technological capacity, given the few instruments created for such purposes. The main types of support to technological diffusion of MSMEs are the availability of information and technological assistance through articulations between enterprises and research institutions. Other initiatives are towards the development of companies of technological basis, through incentives to start incubators, to support feasibility studies or venture capital. The Brazilian government established a new policy for competitiveness in 2004, the Politica Industrial, Tecnológica e de Comércio Exterior - PITCE. The lines of directions involve both horizontal policies (for all sectors of the economy) and vertical ones (for four specific sectors considered strategic for the development of the economy and international insertion of the country: pharmaceutical, software, capital goods and semiconductors). Those are capital-intensive sectors structured by large enterprises, rather than labor-force sectors (which is the case of SMEs). The instruments 
of PITCE include mechanisms of credit access and investment attraction. Thus far this policy resulted in a broad array of initiatives, in various stages of planning and implementation. One of the actions PITCE has is the Local Productive Arrangements Program (Programa de Arranjos Produtivos Locais), in which there is the Program of Industrial Export Extension (Programa de Extensão Industrial Exportadora - PEIEx), driven to clusters of SMEs in any sector and value chain. The government provides consultants to companies based on local productive arrangements to help them solve management and technical challenges. In general, the PITCE programs targeting SMEs have as principal goals:

I to improve the firm's access to credit lines, through the introduction of new regulations to make feasible the financing with lower interest rates and additional charges; besides the creation or reinforcement of guarantee funds, for the financing of production capacity.

2 to increase the SMEs' participation in the national exporting, through sectored actions mainly related to segments of low technological intensity, aiming at their modernization, increasing product values, penetration in new markets and foreign market training.

\subsection{Analysis}

\subsubsection{Ongoing business linkages projects and programs in Brazil}

The BL project called Projeto Vinculos was created in 2004 as the result of collaboration between the German Cooperation for Development (GTZ), United Nations Conference on Trade and Development (UNCTAD), Ethos Institute, Fundação Dom Cabral and SEBRAE. It comprises a steering committee aimed at getting companies, professional associations, and organizations capable of building sustainable BLs mainly in the north and northeastern regions of Brazil. We analyzed, after semi-structured interviews with key respondents (from MNCs, SMEs and the representative of the project), three Projeto Vinculos subprograms: a supplier training program in Bahia, Projeto Vinculos Pernambuco and Projeto Vinculos Ceará. The Supplier training program is funded by large companies (MNCs) and suppliers, with monthly contributions, at a ratio of around $50 \%$ and $30 \%$, respectively, while the remainder is covered by the public partner institutions, such as SEBRAE. To focus on suppliers' development, each MNC designated target suppliers, some already supplying, while others with a strong potential, but still with weaknesses. In 2008 Projeto Vinculos had some 180 SMEs comprising about 2,500 employees participating in its qualification programs. Not only SMEs but also the participating MNCs have observed the positive impact of the project: they have been assuming greater responsibility for their local suppliers as they have been recognizing the benefits of 
strengthening SMEs, as this in turn strengthens their supplier base. Most of the current supplier development programs (SDP) existing in Brazil were created from the partnership of companies, public authorities and specialized consultancies. The work model was first applied in 1995, in the state of Espírito Santo, by request of some MNCs. Several relevant sectors from Espírito Santo were brought together at that moment, such as the Trade Union of Companies from the civil construction and metallurgy industry. A similar program was developed in the state of Minas Gerais and was later deployed to other states. Today, there are three SDPs in the states of Espírito Santo, Maranhão and Pará, as really structured programs.SDPs such as Projeto Vinculos have as their main objective to train suppliers to better serve large companies based on their requirements, and thus strengthen the local industry, especially the SME sector. Moreover, such programs bring together professional associations and business development service providers, such as SEBRAE and SENAI (National Industrial Training Service). While many SDPs have a structural focus connected to the base industry and open to every sort of SMEs willing to participate, Projeto Vinculos focuses on large companies' requirements and their supply needs. This in turn is expected to generate the appropriate knowledge and technology transfer to the SMEs involved. Most suppliers in both SDPs and Projeto Vinculos are service providers, and the goal of procurement divisions in MNCs is not only to obtain high-quality end-services, but also to certify that they were produced according to high-quality process, as mentioned by an MNC's manager: '... SMEs suppliers provide state-of-the-art services, but may fail to pay the employees' social security mandatory taxes. We do not want this scenario... a state-of-the-art work would not be possible if part of the workforce had occupational health problems. So, this is the purpose of the training program.'

The typology proposed by Gereffi et al. (2005) was employed to analyze the relationship between companies, classifying the purchase and sale relationship standards on three dimensions: $\mathrm{I}$ ) information complexity levels (information required throughout the value chain, especially concerning product process specifications); 2) codification ability: whether the information on a specific transaction can be coded, decoded, and transmitted, at low costs (depending not only on the information complexity, but also on the companies' effort to code such information); 3) suppliers' capacity (whether suppliers are able to meet the requirements dictated by MNCs in their transactions).

\subsubsection{Training and technology transfer}

As far as company relationship and technology transfer standards are concerned, information was proven to be of low complexity, as most transactions refer to routine and maintenance operations. The interviews reveal a low technological 
complexity environment of goods manufacturing and service provision in serving MNCs, although specific technical knowledge and strict safety standards are required. The reliability of information from the programs analyzed may be ranked as both high and low, as some companies already have such ability, while others are less developed. The codification of products and procedures adopted by companies participating in the programs does not involve cutting-edge technology. We observed high capacity to perform technical activities, but low managerial ability, which is exactly the main point to be developed according to Projeto Vinculos' and SDPs' goals. As the complexity of transactions is product specific, complex transactions will only take place in existing companies as new types of transactions are developed. In view of the nature of the goods offered, partnerships in training, management and certifications offered, suppliers are very likely to reach high levels of codification ability.

The technology transfer standards (Jeppesen and Hansen, 2004) in the programs analyzed were primarily concerned with improvements to management practices and adjustment of minimum management quality requirements, not reaching the production technology frontier level. The programs did not present examples of MNCs' technicians working closely with suppliers. Instead, thirdparty organizations were subcontracted for suppliers in in-company training: ‘... all training programs are outsourced; we work with SENAI for environmental affairs; and SEBRAE assists us in business quality and management. As soon as a new supplier joins the program, it is assessed, and the company undergoes a training process, where it is evaluated under criteria based on the MNC requirements.'

With respect to the BL fostering programs, suppliers have reaped the following benefits: acquisition of management practices and techniques, knowledge on applicable law and later compliance with them, increase in business volume, easier access to professional associations, strengthening of business ties with neighboring clients and internal training at low costs. SMEs in general are hardly aware of the current law and certification requirements. Environmental license certificates, which are essential to do business with export companies, were, in some cases, unknown or ignored. The programs are an opportunity to provide such knowledge so that these companies meet legal requirements. The benefits of BLs mentioned by MNCs were: increased supplier reliability; long-term supply maintenance (avoiding the constant change of suppliers); relationship that makes suppliers more knowledgeable about MNCs' requirements and needs; assurance of relationship continuity, and making MNCs more confident about supply stability.

Spillovers, considered as direct and indirect benefits from BLs to local economy, were observed in the programs evaluated, although the literature (Girma et al,, 2008) is inconclusive on how to identify them and whether the benefits are related to BLs or are a consequence of other exogenous variables. Another benefit 
observed, for example, was the creation of supplier forums, where SMEs suppliers meet on a regular basis to discuss common issues and encourage interaction, which generates new business opportunities. Suppliers' admission to the program is not always easy or automatic, although they reap benefits and get training to improve their performance in the market. Companies have cultural factors that influence such admission. In Projeto Vinculos, companies join the program after a phase called 'engagement'. MNCs are first engaged, and, subsequently: '... the lessons learned in the projects point out that engagement meetings should be held in the MNCs premises, with their [suppliers] own invitation, as these meetings make clear that it is an opportunity for suppliers to be qualified and meet specific requirements from MNCs that generate business. Engaging SMEs in large companies is different from doing so in Industry Associations, or in SEBRAE, for example.'

Realizing that information should be shared in several ways is a challenge in the engagement phase. Suppliers may fear the loss of business autonomy, besides having their main internal weaknesses exposed to important business partners. As a preliminary status evaluation is performed at the beginning of the linkage, such weaknesses may be an initial barrier imposed by MNCs. That can be used as a weak point in the state's role as a direct leader in BL programs, since SMEs' weaknesses may represent evidence for punitive actions, such as fines. Therefore, one of the main aspects for BL programs to succeed is trust, both in the program as a whole, and among participating organizations.

\subsubsection{The role of the state government}

Most interviewees in BL programs were asked about the state role as a promoter of BL. SDPs had a number of actions jointly taken by institutions and public authorities, ranging from institutional and financial support to public-sector coordination (in SDP-Maranhão), where Projeto Vinculos has formal agreements with BDS institutions and certain departments of MDIC. We tried to identify successful practices or association opportunities between government and programs. One challenge we observed is the bad image the state has when it comes to its capacity of effectively managing private sector issues and programs. For example, when a supplier was asked about the government performance in the BL program, the following answer was given: ${ }^{\prime . .}$ government has the role of improving the overall business environment, but it is not skilled to directly manage a program like this, because they lack managerial capabilities.' The possibility of using the program for political purposes, and the consequent shift in focus, is another negative aspect observed concerning the role of the state: '.. one of the main grounds of this program is the apolitical aspect, benefiting companies and communities for their overall development, and not benefiting few people for political purposes.' 
However, good examples of close relationship with the government were also observed: '... the municipal government is one of our partners because our company is installed in the city industrial area, and we have a program for using local labor, bringing suppliers, and we somehow receive tax incentives. There is also an internal training, paid by the company, in partnership with universities and federal, state and municipal institutions.' Another positive example of the state came from the interview with SDP-Maranhão. As the MNC was privatized during the process, the business environment was impacted, and many suppliers were not prepared to face this new reality. After that, companies from other states, especially from the south and southeastern Brazil, with a greater degree of competitive edges, could be set up there. That was enough awareness that a supplier training program had to be created. Then, the state was the promoter of a process joining the interest of companies, suppliers and buyers, professional associations (created to support and maintain the companies) and the state: 'We released the program, identified the demands from these large-sized companies and realized that we had to attack the management issue, with partnerships with the Labor Department, SENAI and so on.'

Upon the creation of SDP-Espírito Santo, institutional support was more important than financial. It is presently administered by the Industry and Trade State Department, which delegates important decisions to a managing committee, where the government participates with the program partner companies.

\subsection{Conclusion}

Local suppliers' development can be supported by special programs, but their competitiveness is also dependent on a favorable enabling environment comprising broader policy, economic, social and cultural aspects. Therefore, the overall government policy of the country matters, not only industrial policy. Brazil seems to work on fostering micro and SMEs, but it still lacks public policies specifically focused on fostering BLs. A study by Almeida et al. (2007) mapping the status of BL-related activities in the country did not find any federal public policy specific to them, although policies and programs with other purposes could contribute somehow to generate BLs. Our field study also confirmed their conclusions. Generally, linkages between the domestic economy and foreign investors seem to be largely corporate-driven and not part of a national policy. Nevertheless, the country has a number of policies that exhibit great potential to contribute to strengthened BLs, such as the recent SME Law.The strength of the analyzed programs lies in the synergy among companies (MNCs and SMEs), public authorities (such as state development departments), third-sector organizations (such 
as non-governmental organizations), professional associations (such as industry associations), business development service providers (such as SEBRAE) and investment promotion agencies (such as APEX). No specific federal policies intended to forge BLs were identified in this research, occurring only at state level, such as in some SDPs. The programs developed in partnership with local governments worked properly, which means that while the state is not a key player in BL programs, its participation may bring broader benefits, as well as deeper and more structured impacts in local communities or in society itself. The public sector, therefore, can develop public policies and programs to foster BL, but should consider the following remarks, as identified in our analysis:

I Complementary policies should be targeted at creating linkages to strengthen local or regional industrial policies. The state of Maranhão, for example, in an attempt to strengthen its industrial basis, made use of more than tax incentives to attract companies. Complementing the industrial policy, a BLstrengthening program was conducted, since without high-qualified suppliers production costs would increase and business environment would be less attractive for MNCs. Also, by attracting business to a region, the government must make sure it provides minimum operating conditions, such as a strong base industry and basic service provision. Instead of restrictive policies (such as creating criteria to compel large companies to buy from local suppliers), there are alternatives that may encourage companies to participate in BL programs, such as incentives for workforce training and managerial development of suppliers.

2 Educational policy and capacity building is also part of the promotion of BLs. When a BL program is developed, it is possible to identify common problems within companies and form specific groups to target them, besides promoting the exchange of experience and knowledge among the several participating companies, which delivers economies of scale in training and qualification. The extent to which the local SME sector will benefit from technology and knowledge transfer will also depend on the SMEs' absorptive capacity.

3 MNCs are key players in technology transfer, and the state is capable of attracting them through its investment attraction policy. Such technology transfer may occur upon, for example, the outsourcing of MNCs production phases with local SMEs. The participation of research institutions and universities may also be promoted, intensifying the technology development and transfer to local companies.

4 The business environment should be developed, since bringing companies together may generate new business opportunities. Even though the programs were mainly intended to foster buyer-supplier linkages, supplier-supplier businesses were boosted. This is because SMEs are in different stages of produc- 
tion and some may supply goods and services to the others, and then to large companies or MNCs. Therefore, the state should encourage local dynamics, promoting forums for companies to discuss problems and deliver solutions.

Conflicts of interests may drive governments away from leading BL programs, as unveiling a company to governmental institutions may be seen with skepticism by the private sector, especially for companies with some kind of irregular status, which may not be uncommon for a micro or small company in less developed areas. A third institution is more reliable to intermediate companies' and government's interests: business development services providers may have more legitimacy to lead and operate a BL program. Also, although MNCs have technological know-how and administrative capacity, technological and managerial training are generally beyond their core business. BL policies may be important complements to local industrial and development policies. For the states sheltering the most qualified companies, BL may be forged with a special focus on technology transfer, together with the industrial policy. Successful policy and regulatory reform to improve the business environment require that the Government collaborates closely with the private sector. The success of SEBRAE and IPAs, such as INDI and Pólo-RS, may be attributable also to their constitution and participation of the private sector. Moreover, the Government should be aware that BLs can only be effective when companies recognize a vested interest in forging them.

Projects like Projeto Vinculos are seen by some MNCs to have great potential of rendering SMEs more concerned about environmental and safety issues. IPAs may help to provide such consciousness of new requirements, such as the green procurement concept and the Restriction of Hazardous Substances (RoHS) Directive (in manufacturing electronic and electrical equipments). Awareness is important since the majority of SMEs still understand those requirements as an obligation, and not as a competitive advantage. Their sustainability depends also on their insertion in new markets, and not on the dependence on one or some MNCs. Management skills are also needed, mainly in the areas of environmental and quality management. MNCs are not prepared to provide training for those SMEs, except for very specific issues, so this may be the role of IPAs, BDS providers such as SEBRAE, or business associations, such as 'Federação das Indústrias'. Training mechanisms are also available in the market, but many SMEs lack this information and resources. Many capacity-building programs fail because they lack maintenance and evaluation. It is necessary to keep reviewing the rationale and mechanisms of a linkage program to ensure that it remains relevant and effective. Most linkage programs evolve over time in order to meet changing market conditions. 
To conclude, the creation of MNC-SME linkages is, in fact, neither easy nor automatic. The existing levels of host country technological and structural development will determine what types of linkages will be the most appropriate. So, emerging markets need to identify the types of investments that are most likely to form the types of linkages best suited to the country's stage of development, and ensure that barriers to those types of linkages are minimized. Indeed, linkage programs are never the same, and local conditions are distinct, which demands a comprehensive investigation of the specific situation. The linkage programs are designed to meet specific region needs and, consequently, to promote development. This calls for a regional and subregional approach for a country the size of Brazil.

\section{Notes}

* EAESP-FGV, São Paulo, Brazil.

** Mike Pfister is contributing to this chapter in his private capacity. Authors are grateful to Milber Fernandes Morais Bourguignon from the Brazilian Development Bank (BNDES) for his insightful contribution.

\section{List of references}

Almeida A., G. Cretoiu, G.D. Mendonça, J.P. Rossetti and P.T.V. Resende (2007) The Brazilian Case on International Good Practices on TMC-SME Linkages, Research Report Projeto Vínculos, UNCTAD, New York.

Bornstein L. (2003) 'Management Standards and Development Practice in the South African Aid Chain', Public Administration and Development 23, 393-404.

Brazilian Central Bank (2009) Statistics Report, BACEN, Brasília.

Brazilian Micro and Small Business Support Service (2008) Anuário do Trabalbo na Micro e Pequena Empresa, SEBRAE, Brasília.

Coviello N.E. and R.J. Brodie (1998) 'From Transaction to Relationship Marketing: An Investigation of Managerial Perceptions and Practices', Journal of Strategic Marketing 6, I7 I-I86.

Gereffi G., J. Humphrey and T. Sturgeon (2005) 'The Governance of Global Value Chains', Review of International Political Economy 12, 78-104.

Girma S.G.H. and M. Pisu (2008) 'Exporting, Linkages and Productivity Spillovers from Foreign Direct Investment', Canadian Journal of Economics 4I, 320340.

Giroud A. (2006) 'Is Government Support Really Worth It? Developing Backward Linkages in Malaysia', in A. Tavares and A.C.T. Aurora (eds.) Multina- 
tionals, Clusters and Innovation: Does Public Policy Matter?, Palgrave Macmillan, Basingstoke.

Giroud A. (2007) 'MNEs Vertical Linkages: The Experience of Vietnam after Malaysia', International Business Review 16, 159-176.

Giroud A. and D. Botelho (2008) 'Policies Promoting MNEs Linkages in Host Economies: A Comparison Between Brazil and Malaysia, Global Forum on International Investment, OECD, Paris.

Ivarsson I. and C.G. Alvstam (2004) 'International Technology Transfer Through Local Business Linkages: The Case of Volvo Trucks and their Domestic Suppliers in India,' Oxford Development Studies 32, 241-260.

Jenkins B., A. Akhalkatsi, B. Roberts and A. Gardiner (2007) 'Business Linkages: Lessons, Opportunities and Challenges', International Business Leaders Forum of The Kennedy School of Government, Harvard University Press, Cambridge. Jeppesen S. and M.W. Hansen (2004) 'Environmental Upgrading of Third World Enterprises Through Linkages to Transnational Corporations: Theoretical Perspectives and Preliminary Evidence', Business Strategy and Environment I3, 26I-275.

Krause D.R., R.B. Handfield and B.B. Tyler (2007) 'The Relationships Between Supplier Development, Commitment, Social Capital Accumulation and Performance Improvement', Journal of Operations Management 25, 528-545.

Kumar S. and T. Bergstrom (2008) 'An Exploratory Study of the Relations Between the U.S. Manufacturers and Their Local Distributors in Developing Markets', Information Knowledge Systems Management 7, 30I-334.

Langfield-Smith K. and M.R. Greenwood (1998)'Developing Co-Operative Buyer-Supplier Relationships: A Case Study of Toyota', Journal of Management Studies 35, 331-353.

Meyer-Stamer J. and S. Seibel (2002) 'Cluster, Value Chain and the Rise and Decline of Collective Action: The Case of the Tile Industry in Santa Catarina, Brazil', Working Paper, Institute of Development Studies, Brighton.

Meyer-Stamer J. (2006) 'Good Practices in the Promotion of Businesses Linkages from an Operational Perspective: Evidence From the Field', UNCTAD Expert Meeting, United Nations, New York.

Observatório Social (2005) Os Investimentos das Multinacionais no Brasil, Panorama Histórico, Tendências Recentes e o Desafio do Desenvolvimento com Promoção de Direitos, Observatório Social, São Paulo.

Sako M. (2004) 'Supplier Development at Honda, Nissan and Toyota: Comparative Case Studies of Organizational Capability Enhancement', Industrial and Corporate Change 13, 281-308.

Shen X. (2008) Linking Local Suppliers to Multinationals: How Can Governments Play a Useful Role?, World Bank, Washington. 
UNCTAD (200I) World Investment Report 200I: Promoting Linkages, UNCTAD, New York.

UNCTAD (2005) Positive corporate contributions to the economic and social development of host developing countries, UNCTAD, New York. 



\title{
9 Is attracting foreign direct investment the only route to industrial development in an era of globalization?
}

\author{
The case of the clothing and textiles sector in South Africa
}

\author{
Soeren Jeppesen and Justin Barnes*
}

\section{I Introduction}

Staying competitive in the global economy in the present era is highly challenging. While some nations, industries and firms successfully manage this, others struggle; still others have difficulties in competing at all. The South African government is ranked as a leader in Africa, capable and well resourced, with in- and outbound levels of foreign direct investment (FDI) among the highest on the continent. The South African textiles and clothing industry is also well established, diverse and experienced. Nevertheless, both government and industry have been struggling to meet the challenges of global competition since the coming of democracy in South Africa in 1994, and FDI into the industry has been far behind the levels of other African countries (Lesotho, Mauritius, Kenya), not to mention Asian countries such as China and India. Major changes in the external environment have taken place since 1994 which have clearly had an impact on the industry's development. Asian firms, and particularly those operating in China, have become dominant over the last IO-I5 years, aggravated by the termination of the Agreement on Textiles and Clothing (ATC), and as such, the Multi-Fibre Agreement (MFA), which until its discontinuation had ensured a system of quotas among textiles and clothing producing countries until the end of 2004. Finally, in 2000 the African Growth and Opportunities Act (AGOA) allowed among other things, preferential access to African clothing producers entering the US market. This was, however, subject to certain conditions, resulting in South African firms struggling to take advantage of this agreement.

The South African state, both prior to and after 1994, has had an active and rather controlling role in the industrial development of the sector. While the state played a major role in building the textiles and clothing industry from the I930s to its peak in the 1980 s, it has also been party to the downturn it has experienced since. The South African textiles and clothing industry had grown to a consid- 
erable size by the mid-I980s, employing approximately 300,000 persons (Joffe et al,, 1995). Since then, the South African firms have been on a steep learning curve, having been forced to reconsider their business strategies and embark on development trajectories quite distinct from those traversed previously. All in all, the closure and downsizing of a substantial number of firms has led to a loss of thousands of jobs and today the industry 'only' employs about 127,000 persons (Barnes, 2008; 2009). The (new) South African government and its Department of Trade and Industry (DTI) have similarly faced difficulties with regard to the design and implementation of national programmes and policies since 1994. While attraction of FDI has been prolific in the automobile industry, the government has been inclined to rely on an export-oriented strategy for the domestic textiles and clothing manufacturers that is de-linked from FDI.

Among the many studies which have addressed the complexity of formulating and implementing industrial strategies and policies for the clothing and textile industry, three related factors have been emphasized over the last decade. Firstly, the 'one-size-fits-all' approach that existed previously as part of the Washington Consensus has been consistently criticized. Schulpen and Gibbon (2002), for example, have argued in favor of assessing the (real) private sector when formulating industrial policies. They emphasize the importance of understanding the dynamics of a particular country and how its private sector is uniquely configured. Secondly, in contrast to this static perspective embodied by the Washington Consensus, Rodrik (2004) has argued that industrial policies are about the process: the ability to adjust over time according to the changes taking place. He further suggests that while earlier viewpoints proposed the superiority of either the state or the private sector, more recent focus has been given to ensuring governmentto-business collaboration. Thirdly, Schmitz (2007) highlights the importance of formulating and implementing industrial policy in accordance with the strengths and weaknesses of a particular industry, with particular attention to the configuration of the key segments of the industry. That is while attraction of FDI might be appropriate for one industry in one situation, focus on export orientation might be appropriate for another industry in a different situation.

This chapter assesses the case of the textiles and clothing industrial policy of South Africa, vis-à-vis the perspective as outlined by Schmitz (2007). As such, it examines the feasibility of implementing strategies that emphasize the importance of either FDI, the pursuance of export strategies and linking to Global Value Chains, acquiring licences or using Joint Ventures, to achieve global competitiveness in the present era.

In light of these profound global shifts and with a focus on the cut-make-trim (CMT) and clothing manufacturing subsectors of the industry, we assess two questions: 
I Although theory suggests that the best option would have been to attract FDI and to facilitate its spillovers on indigenous (South African) firms, the South African government chose to follow a strategy of export orientation without FDI. What were the motivations for this (also seen in light of the South African government choosing to attract FDI in the automotive industry)?

2 What can we learn from this case in terms of policy recommendations for governments in other developing countries?

The chapter draws on primary and secondary data to complement its theoretical foundations. The primary data consists of information from the benchmarking programs of the Cape and KwaZulu-Natal Clothing and Textiles Clusters; two industry development initiatives receiving support from provincial and local government in South Africa. The firms belonging to these two programs constitute approximately $25 \%$ of the total South African clothing and textile industry's output and employment. The Clusters have been in place since 2004 and 2005 respectively, and the performance of participating manufacturers has been assessed annually during this period. This provides us with detailed information on recent developments in the industry, as well as the ability of the firms to adjust to the changing competitive environment and the challenges faced.

Secondary, data inputs are based on information from key stakeholders (government, trade associations, researchers) obtained through interviews conducted by the authors. A range of materials (articles and reports) on the industrial development of the country, on government policies, and on the textiles and clothing industry (domestically and globally) constitute another information source. Lastly, reference is made to academic assessments of development trends pertaining to the South African automotive industry.

The structure is as follows. This introduction to the chapter is followed by a discussion of the theoretical approaches outlining industrial policy implementation in developing countries, focusing on Schmitz's framework (2007). An indepth assessment of the case of South Africa is then undertaken, and the situation with regard to government and industrial initiatives in the textiles and clothing industry from the mid-I990s until present day is outlined. Two key issues - concerning the absence of FDI in the South African textiles and clothing industry, as well as current industry weaknesses - are raised herein. The government focus on export strategies - rather than one focusing on the attraction of FDI - is then discussed from an analytical viewpoint that favors the latter over the former. The reason for the failure of this industrial policy, which has plunged the industry into dire straits today, is therefore examined. Finally, we conclude by discussing the potential opportunities and weaknesses of a FDI-focused strategy, and outline a set of potential policy recommendations for the South African 
government, as well as other developing country governments and policymakers facing a similar scenario.

\subsection{Industrial development and policy: Theoretical positions}

Numerous and contradictory perspectives have been formulated on how to pursue industrial development in developing countries. The dominant industrial development theories of the 1950s, 1960s and I970s argued for developing countries to pursue a state-based development trajectory, coined as an import-substitutingindustrial (ISI) strategy. The neo-liberal revival in the late 1970 and I980s modified this argument in favor of more open economic policy; an export-orientatedindustrial (EOI) strategy; and a less pronounced role for the state. Today it is evident that industrial development is not about the adoption of one approach over the other, but rather about how both states and private firms (domestic and foreign) interact in order to support industry. In the best case scenario, public and private spheres interact with other actors such as unions, researchers, consultants, NGOs and civil society representatives. Pursuing national industrial strategies, devising appropriate policies, and implementing beneficiary programs successfully have become a complex and challenging matter facing developing economies. However, these remain important interventions, given the limited economic development and persisting issues of poverty and inequality that such countries have experienced over the last 40-50 years.

In addition, global (capitalist) economic conditions have provided ever-changing opportunities and challenges that complicate the pursuit of industrial development for developing country governments and industries. While the success of the Asian new industrialised countries (NICs) in the I970s and I980s has been linked to the pursuit of EOI-strategies, the same opportunities have not been open to countries that followed development paths later on (Rodrik, 2004; Schmitz, 2007). Presently, the BRICs (Brazil, Russia, India and China), and other emerging economies like Malaysia and South Africa, seem able to leverage the necessary capabilities required to exploit certain development options. However, the situation will most likely be different for other developing countries that attempt to do so in the near future.

As it has become clear that the pace and state of development differs among developing countries, and terms like 'middle income', 'low middle income' and 'less/least developed' have been employed to describe such countries in various stages of development, there has been a movement from the 'one-size-fits-all' approach towards a recognition of diversity among developing countries. The emphasis that theory places on the role of the developing country government in 
markets and in terms of industrial development has changed over time, as has the view of the role of the private sector. With regard to the main means of promoting industrial development, a set of options, policies and supporting arguments has been proposed:

- Export orientation as a means of providing the local industry with better market access, exposing it to competition.

- Attract FDI and Multinational Enterprises (MNEs), where the neo-liberal/ classical arguments in favor of foreign capital injections into the local industry promote the benefits of acquired capital, improved technology and hence support to the local industry in terms of knowledge and technical spillovers, as are associated with FDI (Lall, 1989; Blomström and Kokko, 2000).

- Promote and support cluster initiatives in order to upgrade local firms (McCormick and Pedersen, 1996; Nadvi and Schmitz, 1994).

- Enable local firms to link up with Global Value Chains (Gereffi, 1994; 1999; Humphrey and Schmitz, 2002) in order to facilitate access to markets, human and technological upgrading, skills development and learning.

- Support linkages between local firms (specifically SMEs) and MNEs, as FDI does not ensure the linkages for upgrading will necessarily occur: this implies intensive, long-term collaboration (Altenburg, 2002; UNCTAD, 200I; Giroud and Scott-Kennel, 2006).

This suggests an array of strategies and policy instruments which developing country governments can utilize in their efforts to enhance industrial development and, in particular, build and enhance developing country firms. In addition, Wad and Jeppesen (2006) argue that four generic, private sector strategies have, and can be, pursued by developing country governments in the quest for industrial development:

I State-led strategizing aimed at protecting and promoting indigenous industries and enforcing linkages between foreign investors and domestic companies.

2 Targeting strategies that emphasize clustering of foreign and domestic firms, as well as promotion of linkages in strategic industries and sectors, based on the stage of economic development of the relevant country or industry.

3 Open-door strategies in which advanced factors of production (for example education, business competencies) and supporting sectors (for example research and development) are promoted by the state while abstaining from direct and select interventions in favor of specific industries and sectors.

4 Passive, laissez-faire strategies in favor of market forces (Wad and Jeppesen, 2006, pp. 314-315). 
The above-mentioned industrial strategic and policy instruments are generic in nature, and are applicable to all sectors and firms, recognizing the specificities of the individual industry (Schulpen and Gibbon, 2002; Rodrik, 2004). ${ }^{\mathrm{I}}$ As mentioned above, several authors have argued in favour of founding industrial policy based on the particularities of each country, in contrast to the tendency of the Washington Consensus to a one-size-fits-all' approach (Mkandawire, 200I). The indication is that a major element in ensuring successful industrial development is a nuanced view of the actors involved, and in particular, of the real private sector' in a given developing country context. Instead of formulating policies on the backdrop of the normative position of how industries ideally' should be configured, Schulpen and Gibbon point out that a realistic assessment of the situation (strengths, weaknesses, structure and concentration) in a given private sector is more relevant (2002).

Rodrik has taken the 'developmental state' approach developed by Amsden (1989), Evans (1998) and Mathews (2006) a step further by arguing that, not only is it important to have active participation of the state, but it is as important to have close communication and interaction between the state and the private sector (or 'business community' as he terms it). This interaction is crucial in terms of ensuring that the right policies and programs are pursued, that undesirable or ineffective outcomes are avoided, and that constant adjustments and changes are undertaken to suit the changing needs of the industry. Rodrik argues that devising the right policy is less of an issue than ensuring that a process is in place by which continuous revision and adjustment happens (Rodrik, 2004, pp. 3, 16-19). Rodrik makes the additional points that industrial policy should be time-bound and focused on 'incentives to promote new activities' (Rodrik, 2004, p. 2I), where 'new' products or technologies may assist in diversifying the economy and support the generation of new areas of comparative advantage (Rodrik, 2004, p. 2I). As the surrounding environment and industry change, policies should be revised in order to reduce the risk of bureaucratic rent-seeking in outdated and irrelevant policies.

In line with Schulpen and Gibbon and Rodrik, Schmitz argues that the onesize-fits-all' approach is insufficient if industrial policies are to be effectively implemented. He proposes that industrial policies need to be accommodative of two key issues, namely the technology and the marketing gaps that developing country sectors often experience. The average developing country firm lacks the appropriate technology: often they are out of touch with the most recent sources of technology, they have difficulty accessing technology as a result of copyright clauses, and/or they are in an environment with little national support for innovation (Schmitz, 2007, p. 420). Furthermore, they lack knowledge of international markets and customer requirements given their distance from markets and a lack of the financial resources to establish brands (ibid). 
Schmitz argues that these gaps imply four strategic paths forward: I) attraction of FDI; 2) integration into global value chains; 3) licensing and Joint Venture agreements, and; 4) export of own-designed products, as shown in Table 9.I.

Table 9.1 Four strategies of integrating in the global economy

\begin{tabular}{|c|c|c|}
\hline & \multicolumn{2}{|c|}{ Technology gap } \\
\hline & Wide & Narrow \\
\hline \multirow{2}{*}{$\begin{array}{l}\text { Wide } \\
\text { Marketing gap } \\
\text { Narrow }\end{array}$} & $\begin{array}{l}\text { Access to technology and markets } \\
\text { are both severe challenges for local } \\
\text { firms. Foreign Direct Investment is } \\
\text { preferred strategy. }\end{array}$ & $\begin{array}{l}\text { Challenge is not technology, but } \\
\text { marketing. Integration into value } \\
\text { chains co-ordinated by global } \\
\text { buyers is most applicable. }\end{array}$ \\
\hline & $\begin{array}{l}\text { Challenge is not marketing, but } \\
\text { technology. Acquiring technology } \\
\text { through licensing seems best } \\
\text { option. Alternatively, pursue Joint } \\
\text { Venture. }\end{array}$ & $\begin{array}{l}\text { Technology and marketing gaps } \\
\text { are narrow. Local firms can export } \\
\text { own-designed, complete products } \\
\text { directly. }\end{array}$ \\
\hline
\end{tabular}

Source: Schmitz, 2007, p. 422

In agreement with Rodrik, Schmitz highlights that the process should necessarily occur in each industry supported by in-depth - or at least, sufficient - knowledge regarding the industry in order to devise the relevant programs and support initiatives applicable to the situation at hand. He further argues that this should occur at the subsector level, in line with Gibbon and Schulpen's perspective regarding the nuanced view of the actors in private sector groups of firms in a given industry (Schmitz, 2007, p. 422, 426).

Assessing the role of developing country governments in formulating and implementing industrial policies and programs is now a far cry from the one-sizefits-all' approach that dominated in the I960s through to the early I980s. Instead, successful formulation and implementation of industrial policy require the ability of government to engage with the private sector, set a process in motion, and devise targeted, time-bound, and hence highly diverse and locally adapted approaches to targeted problems. Based on Schmitz's framework and the four strategic options outlined above, we will investigate a scenario inherent to the South African textile and clothing industry. The relevance of this case is I) the apparent capability of the government in terms of designing and implementing industrial policies, 2) the changing competitive environment constantly challenging a wellestablished industry, and 3) sufficiently detailed data, which allows for a thorough assessment of the development over the last 15-20 years and of the extent to which the propositions of Schmitz have or have not been followed. 


\subsection{The South African case: The situation in the textiles and clothing industry}

The Republic of South Africa (hereafter South Africa) spans a geographical area of $\mathrm{I}, 2$ million square $\mathrm{km}$ at the Southern tip of the African continent and has a population of approximately 48 million people, divided into four major population groups (Black African, White, Coloured and Asian/Indian). It is the largest economy in Africa, equivalent to a GDP per capita of USD 2,500 in 2008, and ranks as a middle-income developing country that has a developed industrial base compared to many other developing countries. However, South Africa also has a high level of unemployment ranging from $25-30 \%$ depending on source, as well as one of the highest levels of inequality in the world. South Africa has the largest stock of inward-flowing FDI in Africa and had the highest level of outwardflowing FDI among African countries, given that it is the third largest investor in Africa in 2008, behind the UK and US (UNCTAD, 2008).

While minerals constitute an important part of the economy (ro\% of GDP) and are perceived to be the funding base of modern industrial development in the country - manufacturing and, increasingly, the services sectors are well developed sectors of the economy, constituting $20 \%$ and $70 \%$ of GDP respectively (Fine and Rustomjee, 1995; Marais, 200I). Among the mature and important manufacturing industries are the textiles and clothing industry and the automotive industry. The South African textile and clothing industry is a labor intensive industry employing a considerable percentage of the total manufacturing workforce, while the industry's contribution to the total GDP is relatively modest. The automotive industry is much more capital intensive, is also a major employer, and makes a more substantial contribution to GDP. However, while FDI has been a key element in the transformation of the automotive industry, it has been of minor importance to the development and recent changes in the textiles and clothing industry. Before we address the limited role of FDI since 1994, we briefly characterize the textiles and clothing industry and its strengths and weaknesses. Schmitz's point of departure is that we first take stock of the situation in a given industry with regard to whether 'technology gaps', or 'marketing gaps' or both exist. Then we can assess the appropriate strategy of integrating in the global economy.

\section{THE TEXTILE AND CLOTHING INDUSTRY IN SOUTH AFRICA BY 1995}

The industry developed in a protectionist environment aimed at 'self-reliance', where an ISI- strategy reined. This was further exacerbated by the isolation that was the result of international sanctions during the $1980 \mathrm{os}$. The limited foreign 
ownership in the industry diminished as a range of MNEs disinvested. Still, by the mid-199os, the South African textile and clothing industry was nonetheless diverse, of significant size and of major importance employment-wise, and was accordingly of central importance from an industrial development perspective.

The industry included the full range of firm operations - from very basic, non-diversified producers of raw material inputs, to yarn and textiles mills, cutmake-trim firms and clothing manufacturers - of both low-end and high-end quality garments, and finally a wide range of independent retailers. The industry employed slightly less than the 300,000 persons at its peak in the 1980 s and contributed around II\% of manufacturing output and $2 \%$ to $3 \%$ of total GDP (Statistics South Africa).

Approximately 3,000 firms were active in the sector, with approximately I0$15 \%$ being large and $85-90 \%$ being SMEs. Geographically, the industry was concentrated in the Western Cape and KwaZulu-Natal Provinces, where many firms were located in so-called 'homelands' (Bantustans), due to lower labor costs and generous governement incentives in the area. In South Africa the industry was highly formalized: almost all firms were registered and most employees (more than 200,000) were members of one or another union. ${ }^{3}$ CMT companies and clothing manufacturers mainly supplied to the domestic market (more than $90 \%$ of total output), while the remaining Io\% was exported: the value of clothing exports ZAR 490 million in 1995 . The main supplies came from other South African firms, though imports were increasing. The main customers were six major domestic retailers (constuting 75\%) and small independent shops.

While numerous firms were members of employers' associations (such as the Cape Clothing Manufacturers Association, and the Natal Clothing Manufacturers Association) and the South African Chamber of Business (SACOB), little organized collaboration took place among textiles mills, CMTs, clothing manufacturers and retailers. On the contrary, needs and demands differed vastly along the value chain in accordance with a participant's particular position. To this extent, much contention regarding government policies and the relevant measures to assist the industry regularly arose. While the textiles and clothing industry was a mature and well established, domestically-owned and domestically-oriented industry, it also had a number of weaknesses, given the new competitive environment which it had entered as a result of the liberalization of the economy that took place from 1994, and the lowering of tariffs and other trade barriers that accompanied this move. The isolated nature of the Apartheid economy and the almost total absence of FDI and hence of inputs from the global industry had led to an industry with a number of idiosyncratic features. The absence of external competition and of foreign MNEs, along with an inherent dependence on the domestic value chain, led to a 'South African style of relations in the industry'. Often 
orders were 'guaranteed' and with 'only' South African inspiration on style and fashion, limited design and innovation capacity existed. The level of investment had been low for many years and accordingly the technology used was outdated. Hardly any emphasis had been given to training and skills development among employees and management. The cocktail of outdated technology, a particular type of 'hierarchical' organization, and low skills level meant that productivity was low, too (Joffe et al., 1995; Hirschsohn et al., 2000). As such, the textiles and clothing industry faced a situation in which it experienced a 'marketing gap' in terms of lack of knowledge of foreign markets (both regarding customer/buyer requirements and fashion trends among end consumers) while being focused on the home market - in its own 'homegrown style', and a 'technology gap' operating with old and outdated technology compared to the global industry, due to the lack of investments (domestic and foreign), and a lack of skills development among managers and employees. In comparison with Schmitz's framework, the South African example therefore represents a rather clear situation in which the industrial policy should have focused on attracting FDI. What happened and why?

\subsection{Government responses and policy developments}

We start with a brief contextualization outlining the overall industrial development strategy of the government and then turn to the policies in the textiles and clothing industry. Then we outline what the situation is in the industry today.

\subsubsection{Content of industrial development strategies and textiles and clothing policies}

Following international sanctions of the 1980 s, South Africa had become fairly isolated prior to the advent of democracy in 1994 and the issue of how to reintegrate into the global economy was therefore a pertinent issue to the new government of national unity. While the industrial development strategy of South Africa during the Apartheid period 1948-I994 (and prior) resembled an ISI-strategy, the post-Apartheid period sought a new approach. Instead, an EOI-strategy was implemented through liberalization of imports and exports via the lowering of tariffs, along with growing deregulation and privatization of state-owned enterprises and public utility companies, for example in the water sector (similar to the Washington Consensus). While government lowered tariffs on imports to $22 \%$ on textiles (apparel) and to $40 \%$ on clothing, the main incentive for textiles and clothing firms was the introduction of an export subsidy, the Duty Certificate Credit Scheme (DCCS), which was targeted at providing exporters with 
duty certificates that allowed them to import fabrics and garments at significantly lower tariff rates.

The first overall development strategy (the Reconstruction and Development Program - RDP) initiated in 1994 contained substantial poverty reduction and redistributional elements (Government of South Africa, 1994). The redistributional elements were, however, downsized, when the government commenced a subsequent program; the Growth, Employment and Redistribution (GEAR) strategy in 1996 (Department of Finance, 1996). The neo-liberal inspiration was much more dominant compared to its predecessor, with export-orientation and macroeconomic stability seen as key objectives, following additional liberalization and privatization (Marais, 200I; Padayachee, 2008). ${ }^{4}$ On the other hand, the alliance among the government, headed by the ruling party ANC, the political left-wing and the trade unions, meant that the South African government was less inclined to deregulate the labor market and to pursue a fast-tracked privatization process. The Accelerated Shared Growth Initiative of South Africa (ASGISA) followed the GEAR strategy in 2006 and mainly reinforced the GEAR strategy emphasis on macroeconomic stability, continuation and prioritization of certain key sectors (business-process-engineering, like call centers, and biotechnology) (The Presidency, 2007). However, the ASGISA strategy also envisaged major governmental infrastructure projects and other investments aimed at generating employment in order to boost economic growth over time.

As important as the policies themselves are the capacity and power of the bureaucracy in implementing the strategies and policies. In contrast to most other African countries, the South African state administration was both powerful and well capacitated by the mid-I99os. The key ministries were the Department of Finance, Department of Trade and Industry (DTI), Department of Minerals and Energy (DME), Department of Labor (DoL) and the Department of Water Affairs (DWF). The main center of influence rested with the Department of Finance, which set up the EOI and managed macroeconomic factors of the economy, as well as to some extent with the DTI as it was in charge of policy formulation and implementation. However, the DME, DoL and DWF also had their respective shares of influence in the pricing of main inputs like electricity, labor and water. Overall, the new South African government continued to have a strong hand in industrial development affairs as during the Apartheid period. For example, the government controlled substantial investments through its development agency, the Industrial Development Corporation (IDC), which continued to play a major investment role in manufacturing. Within the overall EOI-type of strategy and the emphasis on macroeconomic stability by the Ministry of Finance, a number of sector-oriented policies and programs have been implemented by the DTI. The more successful ones have been within the automotive industry (see 
Barnes and Morris, 2008). From official sources, the South African government has frequently - at latest with the 'Rescue Plan' (DTI, 2009) - indicated that it is not prepared to see the demise of the South African Textiles and Clothing industry due to its importance as a job creator and the benefits the economy secures from its existing skills base. According to the DTI, the industry plays a vital role in ASGISA planning, as an important job creator for unskilled or semi-skilled workers (DTI, 2007, p. 20).

Following ASGISA, a so-called National Industrial Policy Framework (NIPF) was initiated in January 2007. The NIPF defines the government's approach to the aspects of industrialization under the ASGISA strategy. The NIPF includes strategies with an increased focus on export-oriented sectors and labor-intensive, job-creating industries, including the textiles and clothing industry (DTI, 2007, p. 2).

Furthermore, an Industrial Policy Action Plan (IPAP) was developed and implemented by the DTI in July 2007. The focus of the IPAP was to operationalize the industrial policies formulated under ASGISA and refined in the NIPF, by setting concrete action plans and time frames for the implementation of the strategies. The IPAP combines a set of general plans for the different South African industries and proposes a range of industry-specific strategies and activities in order to build and improve sustainable competitive advantages, among others in the textiles and clothing industry (see Appendix I). A key component to the textiles and clothing industry is the Customized Sector Program (CSP). The CSP was originally completed in June 2005. It was designed to modernize and develop the textile and clothing industry, enabling the rapid advancement of its competitiveness. Phrased differently, it was aimed at closing the technology gap which the industry experienced. However, the CSP was then delayed and revised - see section 5 below - before facing a similar fate to other DTI programs and proposals: either not having any effect on the industry or not having been implemented.Therefore, the main activities related to protecting the industry have partly rested on the aforementioned DCCS 5 , giving manufacturing exporters of clothes and textiles possibilities of certain levels of duty free imports, depending on their level of export (ITAC, 2004) and partly on imposing import restrictions on clothes and textiles from China (ITAC, 2006 - see section 5).

The national government has introduced various initiatives to support the regeneration of the industry's skills base. Regarding workers the support has been through the establishment of the Clothing, Textiles, Footwear and Leather Sector Education and Training Authority (CTFL-SETA), and also by supporting new investments in the industry through the Clothing and Textiles Desk of the IDC. Regarding management - based on the successful clustering models developed to support the South African automotive components industry - limited 
funds for cluster initiatives were secured from provincial and local government from 2004 leading to the establishment of the mentioned Western Cape and KwaZulu-Natal Clothing and Textiles Clusters. ${ }^{6}$

Finally, in an industry where price competition is central, the cost/price level of key inputs (water, electricity and wages) is highly important for competitiveness. The South African government has affected the industry in different ways, both in terms of the level of wages (where the lead ministry is DoL) and the price of water (lead ministry DWF) that have been relatively high, while electricity (lead ministry DME) has been relatively cheap, but recently problematic due to load shedding, supply problems and annual price increases of well over $25 \%$. Probably even more important has been the inability of the South African Revenue Service (SARS) to control the borders of the country, allowing illegal and undervalued imports to impact heavily on certain industries, including the textiles and clothing industry.

In a rapidly changing global environment, the government has seemingly tried to implement different policies with a variety of instruments aimed at I) promoting exports through the DCCS, 2) imposing quotas on Asian/Chinese imports, 3) renewing technology (through the CSP), 4) enhancing skill levels (the CTFLSETA), and 5) supporting clusters, among other initiatives. And yet the industry has continued to experience a substantial decline with thousands of firms closing and more than 150,000 jobs being lost. If we assess this development in the context of the analytical approach by Schmitz outlined earlier, what picture emerges?

\subsubsection{The situation in the South African textiles and clothing industry: Technology and marketing gaps}

Today, the South African textile and clothing industry continues to be an important industry in South Africa; it is still relatively labor intensive and a large employer of semi-skilled and unskilled labour. However, its relative importance has diminished dramatically as the industry today employs approximately 127,000 people (or II\%) of the total manufacturing workforce. The sector's contribution to the total GDP has dropped too, to only around $0.6 \%$.

As highlighted earlier, the strengths of the South African textiles and clothing industry were - and continue to be - the level of experience, in that it is well established, and by now aware of the 'new' competitive situation. In contrast to many African countries, the industry also has different opportunities; that is, a sizeable and growing domestic market, particularly since 2005. This provides the industry locational advantages and the possibility of serving their domestic customers quicker than foreign competitors, given an ability to meet the requirements of improved speed and reliability by the domestic retailers (the customers). 
The basic challenge for the South African textile and clothing manufacturers is to achieve global competitiveness in order to be able to compete, not only in the global market, but predominantly in the - main - domestic market, which is no longer protected to the same degree as in earlier periods. In other words, the South African textile and clothing manufacturers need to enhance their world class manufacturing standards (Barnes, 2008) - in particular leading to a closure of the technology gap, but also of the marketing gap. Social and environmental compliance play a more important role for end consumers both on the world market and increasingly the domestic market as well. This has made the retailers focus more on quality measurements, and securing product quality and working conditions for workers employed at the factories supplying the retailers.

Clearly, the industry as a whole has not so far been able to confront the challenges of reducing production costs, improving quality, efficiency and flexibility and furthermore encouraging specialization. Financial data shows that the turnover of the domestic manufacturers fell by $18 \%$ in the period from 2005-2008, while a comparative set of foreign manufacturers experienced growth of $26 \%$ over the same period (Barnes, 2008). Despite years of only limited investment, the ROI secured by South African clothing manufacturers was moreover only I0\% in 2008, revealing its poor performance.

A closer look at the development in sales volumes among major segments of the industry along with production and employment patterns since the mid-199os tells key parts of the story. The domestic industry continues to be concentrated primarily in the Western Cape and KwaZulu-Natal (KZN) regions, although some outlying activity also exists in the Gauteng area. An estimated I,035 firms are evenly distributed across the formal and informal sectors, of which $33.5 \%$ operate out of KwaZulu-Natal, and 29.1\% exist in the Western Cape (IDC, 2009, p. 4). The domestic textile industry is characterized by plants of varying technical ability, and while few regional differences exist, the greatest proportion of value added is purportedly concentrated in KZN (Barnes et al., 2007, p. 14). The KZN profile of firms is predominantly comprised of CMT firms, and is concentrated on mass market production of garment basics, relative to a Western Cape focus on larger operations servicing a more design-intensive and niche-market focus.

In I998, seasonally adjusted real values of sales of textiles and textile products, knitted or crocheted products and wearing apparel amounted to ZAR 42.9 billion. Io years later, this figure was a mere ZAR 34 billion in real terms (Statistics South Africa, 2009 (www.statssa.gov.za)). If we turn to the major customers, the local production of clothing is concentrated on high-quality items for the middle and high ends of the domestic market, with major retail chains (such as Truworths, Woolworths, Foschini and Edcon) commanding $70 \%$ of this share. Likewise, indexed production in volume has declined, as indicated in Figure 9.I. 
In addition, the increase in imports from 1996 to 2006 of which China's share went from $21.58 \%$ to $78.49 \%$, highlights that South African producers were unable to retain their domestic market share, while imported apparel goods from China and other low-cost producers have moved in strongly on the South African market.

Figure 9.1 Production performance of the South African industry since 1998

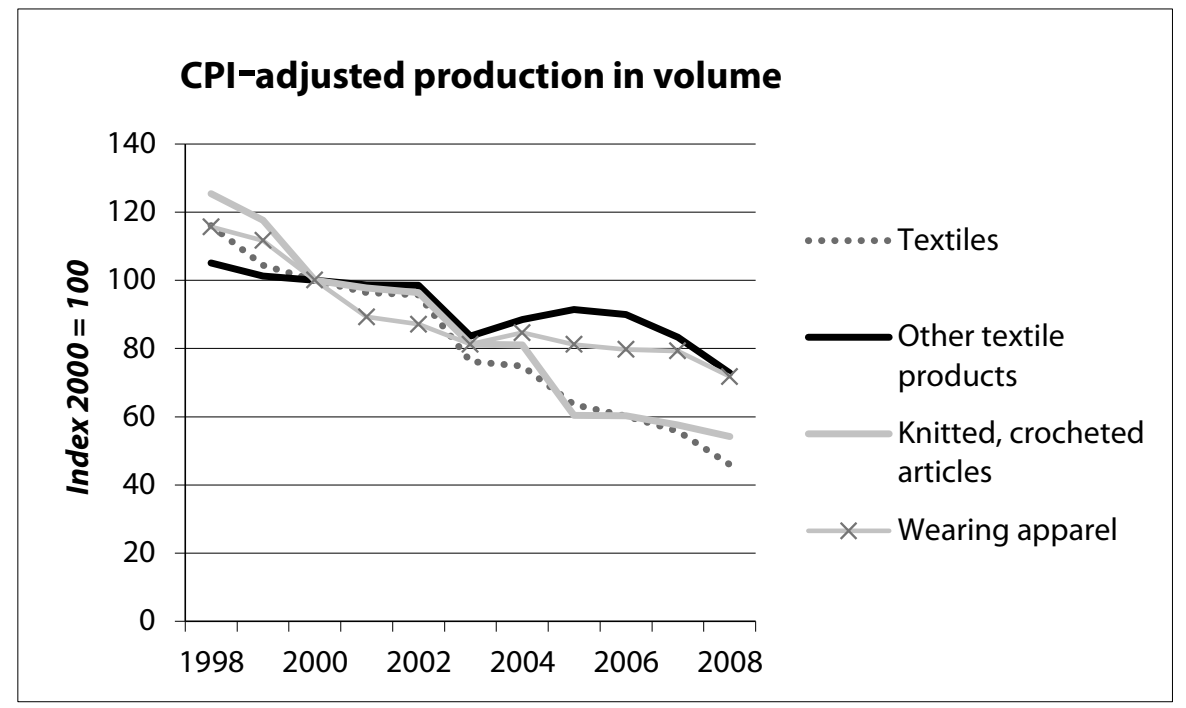

Source: Statistics South Africa (www.statssa.gov.za) ${ }^{8}$

Textiles production experienced a significant decline over the Io-year period, from a real value of ZAR 877 million in 1998 to ZAR 568 million in 2008 (see Figure 9.2). This has been less so for other textile products, which have actually experienced a slight increase in value from ZAR 804 million to ZAR 833.5 million in real terms over the same time span (see Table B in the Appendix). The clothing industry in South Africa contributes $7.2 \%$ of total manufacturing employment in the economy. Over the 2003-2008 period, clothing and textile employment decreased by annual averages of $4.8 \%$ and $3.5 \%$, respectively (IDC, 2009). From 2000 to 2006 the workforce employed in the clothing industry has fallen from 136,767 to 80,576 (Barnes, 2008), and as of June 2008 , to approximately 68,708 people. ${ }^{9}$ In addition, employment in the textile industry has fallen from $55,08 \mathrm{I}$ in 2000 to 46,947 in 2006 (Barnes, 2008, National Bargaining Council). ${ }^{10}$ 
Figure 9.2 Production performance of South African textiles and clothing segments in real sales values, 1998-2008

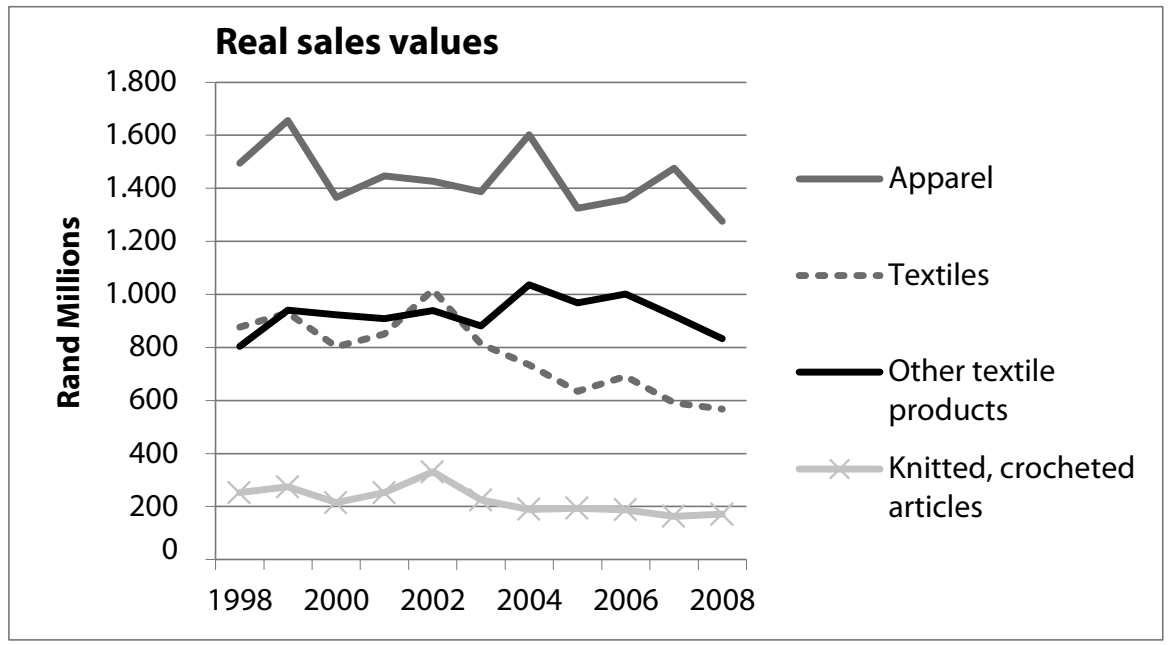

Data source: Statistics South Africa (www.statssa.gov.za) ${ }^{11}$

As another sign of the lack of ability to adjust to the present competitive situation (and reduce the marketing gap), the main customers - the domestic retailers - are generally unsatisfied with the performance of the domestic manufacturers and are therefore shifting to importing from international manufacturers. The main areas of dissatisfaction are; delivery reliability, as well as price and quality of the product. Therefore areas for improvement do exist. The problem is that the manufacturers are not operating on the levels that they should be and are not improving at the speed required to compete and catch up with international manufacturers. This places the industry in a vicious circle of decreased capabilities and lack of investments in the industry, compared to foreign competitors. The South African manufacturers and CMTs have invested an equivalent of less that $2 \%$ of total sales. This is far lower than the foreign manufacturers' average of $5.4 \%$. This means that the industry is using outdated technology and does not spend sufficiently on capability building among the staff. This leads to decreased competitiveness of domestic companies relative to their foreign-based competitors, both on the South African market and abroad. So, in spite of the EOI-policy, the value of exports in 2007 was ZAR 688.5 million, falling $17.5 \%$ from 2006 and to about a third of that in 2003 (ZAR 2 billion). ${ }^{12}$ The industry is clearly in dire straits.

Seen from both the domestic and foreign customers' side (and being the other part of the marketing gap), a major market/customer requirement is of adher- 
ence among retailers to 'fast fashion', lean retailing and manufacturers with short delivery time to the markets, and retailers are thereby heavily dependent on South African manufacturers' ability to deliver on this. Due to the fierce competition in the textile and clothing industry there is a focus on moving into nichemarket production, and to be able to focus on higher value-added products. This change has made research and development key to achieve the new goals and the demands of the retailing sector. While the clothing and textile industry has been changed by transformations in the IT sector and the increased bargaining power of large global retailers, the change process in the South African industry has been held back by the low level of investment, effecting both technology and skills.

We now turn to the South African government's industrial policy and take a look at the structure of relevant policies, why they failed, and why the South African government chose to focus on export-orientation rather than FDI (or one of the other options in Schmitz's framework) considering the large technology and marketing gaps that the industry experienced in the mid-I99os.

\subsection{The mismatch between government policies and the realities in the industry: Why did the South African government follow export orientation and not pursue foreign direct investment?}

We address five issues, I) the emphasis of government on the EOI-type of strategy and on macroeconomic policies (lowering of tariffs, free-floating exchange rate), 2) the quality of the industry-targeted policies, including the DCCS, and the late protection of local industry through quotas on import, 3) the impact of the input prices (electricity, water, wages) on production, and SARS' inability to control the borders, 4) the issues of coherence in government policies, the level of capacity in the DTI, and finally, 5) government-industry collaboration.

\subsubsection{An emphasis on EOI, lowering of tariffs, free-floating exchange rate and macroeconomic stability}

From an industrial development perspective, an EOI-strategy carries merit in aiming to enhance the effectiveness and competitiveness of a local industry. However, being able to make the transition from a closed, domestically-oriented economy to an open, globally-oriented competitive one rests on certain preconditions. Schmitz emphasizes that the local industry needs to have reached both a certain technological level of advancement and a good knowledge of foreign markets (of 
buyers and of end consumers), which the South African textiles and clothing industry did not have by 1995 (see above). The ambitions of achieving macroeconomic stability has been fulfilled which was part of the success in attracting FDI in industries like the automotive sector.

In a transition phase, various support measures and barriers to external competitors need to be in place, as they were in the successful East Asian countries during their transition - and as permitted by the WTO (Kaplinsky and Morris, 2008). However, while lowering tariffs is part of the macroeconomic stability package - which South Africa also has followed - the government decided to decrease the tariffs faster than needed, also within a WTO framework and accordingly limiting the breathing space of the industry. Furthermore, the government abstained from taking any additional measures, one of which might have been implementing a mechanism to assist the clothing exporters handle the impact of the fluctuation in the exchange rate. As a part of the macroeconomic package, the rand has been allowed to float freely against other currencies, which has led to considerable fluctuations and volatility. This is not unusual and numerous examples exist on how to bolster local industries against this effect. However, the South African government has not undertaken any of such initiatives, which in turn have had major implications on the industry, as the rand has moved from its lowest exchange rate of ZAR 5,50 to USD I, to over ZAR II at its highest point of trading. This has created highly unpredictable conditions for the industry, including substantial upturns - and downturns.

Finally, the government has rejected a number of proposals by the industry (see also the following section). For example, national government was unwilling to lobby for adjustment in AGOA requirements. Clotrade had highlighted the possibility of improving export performance by allowing local manufacturers to source fabric inputs from third-world countries and still be able to export to the US and the EU under the same conditions as other Sub-Saharan African (SSA) countries. But the South African clothing manufacturers have had to comply with an additional, three-stage conversion rule in order to access the US market, in addition to the normal conditions stipulated for exporters from other SSA countries, thus limiting AGOA-based exports.

In sum, the South African government chose to follow the Washington Consensus approach to industrial development rather strictly (focusing on macroeconomic stability and lower tariffs (even more than needed) and letting the currency float freely), while refraining from introducing WTO-approved supporting measures. 


\subsubsection{The quality of industry's targeted policies, including the Duty Certificate Credit Scheme and protection of local industry through quotas on imports}

The key policy instruments and the quality of policies targeting the textiles and clothing industry, as well as the goal of the EOI, present a picture of good intentions, but limited success in terms of implementation. In relation to Schmitz's approach and with regard to addressing the technology gap and the marketing gap as he suggests, a variety of alternate options appear to have been viable. On the technology side, if the option of offering incentives to provide FDI were considered too limited, support to local firms in acquiring license agreements and new technology with foreign firms could easily have been established. For instance, investment finance in textile mills is important given the capital-intensive nature of the process, and while this has happened in Swaziland since 2000, no investment has been made in South Africa for a very long period of time.

On the marketing side, the industry has clearly been scarred by the protectionist era of ISI-policies, the sanctions in the I980s, and the dominance of large retailers in the domestic market. However, concerted efforts to promote South African products in the EU and the US have not been attempted, and sensitizing the industry to the needs and demands of the same markets has not been tried either. Another option - of seeking to improve the sector's limited design capacity - has not been pursued in full, either. Building capacity at technical schools and/or setting up distinctive design schools has not been attempted.

While the DCCS has been a major instrument in the development of the industry and agreement has been reached on the need to reform/improve it, it should be highlighted that it is hard to have reforms of the DCCS because it is applied across the entire SACU region and is not South Africa-specific. Furthermore, Clotrade (the export council for the clothing industry) and the DTI could not and do not agree on how to reform the DCCS (see below).

Import quotas on fabrics from China were supposed to be another supporting instrument, but it has had a potentially counterproductive effect on the industry. While the value of imported clothing to the South African market fell by $8.7 \%$ in the period from 2006 to 2007 , from ZAR 6.9 billion to ZAR 6.3 billion, as the government hoped, the decline was more technical than real. In reality this decline in imports is not due to an overall decline in imports, but is the outcome of an amount of forward-buying at the end of 2006 in anticipation of the implementation of the quota system being enforced in the beginning of 2007, thus inflating the imports for 2006 higher than under normal conditions and reflecting a larger deflation of imports for 2007 than would have actually occurred (Clotrade, 2008a). If we were to take a slightly longer time perspective, the value of imports 
of clothing has increased more than $300 \%$ from 2000 to 2007 (Barnes, 2008). In spite of the quotas, China remained the main country of origin for imports into the domestic market in 2008, while the other main countries of import were India, Hong Kong and Mauritius. The figures indicate that the policy seems to have forced local producers down the value chain, competing with low price countries instead of focusing on core competencies, optimizing their competitive advantage of localization and ability to manufacture with shorter lead times to market and greater flexibility. The government-imposed industry strategies have therefore proved largely counterproductive to the local industry.

Therefore, since 1994 the major instrument of policy intervention has been the DCCS, and while other, minor support schemes have been in place, only the late introduction of quotas on Chinese apparel carries some weight. The intentions listed above (and in the Appendix) are extensive, but are marked by a lack of implementation. And again, the striking feature is the lead time associated with launching any such program, as has more recently been the case with the proposed establishment of a Government Rescue Package for the industry in 2009.

\subsubsection{Effects of input prices (electricity, water, and raw materials) and wages}

While levels of tariffs, quotas and the exchange rate constitute a sizeable portion of the competitiveness of the industry, other factors are of importance too. In a price-sensitive industry, clearly, relatively high wages (and relatively low productivity compared to other countries) matters, similarly the prices of other inputs like electricity, water and raw materials (in particular if coming in at undervalued prices due to illegal and/or undervalued imports) are of absolute importance, too.

South Africa has been renowned for its low electricity prices (Van Horen, 1997) both during the previous regime and under the current government. However, during the last couple of years, load shedding and uncertainty of electricity supply have occurred, creating problems and adding to levels of uncertainty in the industry in general. Similarly, water rates have been low in the past, but have risen due to the general scarcity of water (Bethlehem and Goldblatt, 1997). Ensuring that public water remains at an affordable level is obviously of concern, and while increasing prices can act as a means to encourage industry to switch to more efficient/'cleaner' technologies, it is important to have either a scheme in place to facilitate this (for example, favorable loans to the firms that undertake such investments) or to subsidize firms in vulnerable industries according to the loss of competitiveness that the firms might experience vis-à-vis main foreign competitors. None of these supportive measures have been pursued by the government.

Prices of raw materials have been lowered with the reduction of tariffs, par- 
ticularly in the case of yarn and fabrics, as opposed to clothes. This is another part of the EOI-package and in theory appropriate in pushing the industry to a transition, given that appropriate, time-bound measures are in place to assist the industry in overcoming the difficulties of a new and changing competitiveness environment. As mentioned, this has not been the case. And while the South African government lowered tariffs quicker than it was required by the WTO, SARS did not ramp up policing and control of illegal imports at the borders sufficiently. The consequences have been massive illegal imports of fabrics and garments, as well as massive import of inputs that have been undervalued. While this might be seen as an advantage for the part of the industry that is using the input, this has been devastating to the part of the industry producing the inputs leading to their closure. This has in turn lead to both a case of thinned competencies in the domestic manufacturing base - resulting in the industry eventually not being able to utilize the imposition of quotas (as explained above) - and the development of a new informal sector in the industry (based on the illegal imports).

While numerous elements of the South African government's macroeconomic stability initiatives resembled those of the Washington Consensus, few changes regarding wage rates and the labor market took place. In a globalized economy, this approach is by no means necessarily as problematic as, for example, the Nordic, German and/or Dutch model(s) show. However, if an economy's wages are relatively high, than they need to be compensated with higher levels of productivity, which can be secured from skills development, training and new technology and so on. The Sectoral Educational and Training Agencies (SETAs) established by the South African government are one such example, targeting the skills (human resource) gaps that many pointed out by the mid-I99os (Joffe et al., I995). However it was only in the late ig9os that the national system was established, and only within the last couple of years that it has gained any momentum, for example, with the working of the CFTL-SETA. While this very relevant activity might assist the industry in terms of technology and marketing issues, it has taken a long time to come into force and with limited resources when it eventually did. As this is a major component of the Rescue Package of 2009, it seems to add to a picture of the government assistance being 'too little, too late'.

In terms of addressing the need to upgrade the skills of management, these have been part of the cluster initiatives started in 2004 and 2005. Interestingly though, the CCTC and the KZN-CTC have been funded at the provincial and local government level, not by national government institutions as mentioned above. Instead of being a part of a national DTI scheme, the two 'local' government levels have had to initiate their own scheme. Again, though a highly relevant and important initiative aimed at addressing the 'homegrown' features of the industry, these are examples of initiatives coming rather late. 


\subsubsection{Coberence in government policies and the level of capacity in government}

The various policies have not been coherent as the discussions above demonstrate. While the Ministry of Finance has pursued the EOI-type of industrial development through the GEAR, and later the ASGISA strategy, the DTI has been both unsettled and indecisive regarding specific policies for the textiles and clothing industry. We will return to the reasons for this indecisiveness; however the result has been that the DTI has failed to commit to longer-term policy horizons and has delayed extensions of the DCCS and other important initiatives (like the quotas and Rescue Package).

Finally, the policies - in particular pricing policies - employed by the DME and DWF have only partly been aligned with the EOI and the DTI textiles and clothing policies, as only DME and the local electricity prices have been of support to the industry. More importantly - or rather, devastatingly over time - has been the inability of SARS to control the influx of imports and underinvoicing at border posts, which has only led to a more uneven playing field for the South African manufacturers. Given the historical situation with tight control of the borders and the later history of SARS being highly successful in collecting personal income tax revenues, it raises the question of the will of the government to address the well-known problem and hence to support the industry through ensuring a 'fair competitive environment'.

The lack of coherence both relates to increasing tensions between the Ministry of Finance and the DTI, while in addition, the level of capacity in government has decreased over time, in particular with the DTI. We will return to the issue of tensions below. From being a strong and capacitated Ministry in the mid-I99os, frequent changes in staff, ${ }^{13}$ and drainage of qualified staff, have left the ministry much weaker than it had been 15 years earlier. Furthermore, whether for reasons of diminishing capacity or for political motivations, the DTI has been aligned with the trade unions, which have had a considerable impact on its policies. $\mathrm{Nu}$ merous examples of fruitful interaction between government, industry and unions exist - although this has not been the case in the South African experience which in turn has been part of the problematic development since the mid-I99os (see below).

\subsubsection{Government-industry collaboration}

Rodrik and others have argued that it is of key importance that the relationship between government and industry is close and constructive. In the South African case this collaboration seems to have changed from good to bad and has been con- 
strained in various ways as the example of the imposed quotas show. ${ }^{\mathrm{I}}$ While the collaboration between government and industry followed the 'prescription' until 1994 (for particular reasons, due to the close links between a white government and the white business people running the South African private sector) $)^{15}$, this situation changed after 1994 .

As the new ANC-led government took office, the relationship cooled off. To the new government and its alliance partners, the predominantly white business class was seen as a co-conspirator with the Apartheid government and the previous regime. The South African government started to listen more to foreign advisors compared to industry representatives, so the level of engagement between government and industry decreased, as well as the ability to reach compromises on which policies to agree on. The lack of mediating measures following the implementation of the EOI/GEAR strategy is the first example of this. The power resting with the Ministry of Finance in contrast to the DTI and the lack of willingness to allow any industry supportive measure is another - very important - example.

Another example is the lack of implementation of Clothing and Textile CSP, which was a program intended to address the technology gap (and hence an indirect acknowledgement that a gap existed). While industry was in support of the first original proposal, the Southern African Clothing and Textile Workers Union (SACTWU) rejected it and instead demanded that labor market issues be included (to guarantee its hegemonic position in all government interventions), along with substantial financial commitments from South African retailers. Then the retailing sector withdrew its support for the 'new' CSP as proposed by SACTWU, resulting in the effective freezing of the initiative. ${ }^{16}$

A final, recent example took place in 2007, in which the South African government proposed the above mentioned quotas on imports from China to protect the domestic industry and give it time to restructure and become globally competitive (see ITAC, 2006). The objective of the South African government was to force the local retailers to source from local manufacturers and CMTs, and thereby regain the jobs lost over the last few years. However, while the logic appeared correct, the timing was wrong as many factories had already been closed or scaled down, making it impossible to supply the quantities of low cost products demanded by retailers in the domestic market (Clotrade, 2008b). Accordingly, implementation was enforced against the wishes of South African retailers and clothing manufacturers, who argued that the quotas were imposed too late and would not therefore have the desired effects: because many local producers used fabrics and finished garments sourced from China in their production. The result was that imports of textiles and clothing sourced from China increased in 2006 and then fell in 2007 (as mentioned above), but primarily because retailers 
had started to source low-priced clothing and textiles from other low-cost destinations, such as Mauritius, Indonesia, Malaysia and Vietnam, with no import quotas and efficient clothing and textile industries (Morris and Reed, 2008). So, instead of assisting local manufacturers, quotas first led retailers to push forward supplies and then, in the light of increased uncertainty about the future situation of China, some retailers started to source from other low-wage countries. All in all, the quotas came too late and had little or no effect in terms of boosting industry performance. Had the quotas been in place earlier - for example, from 1994 onwards - along with a concerted effort to control the borders against illegal and/or underpriced imports as well as a better assessment of the situation in the industry paired with the types of 'world class standard initiatives' that have been undertaken now, the chances of a different development seem fair.

The view from the government, in particular the DTI, has been that apart from these governmental actions taken to improve the conditions for the textile and clothing sector, further improvements need to be undertaken by the private sector and the industry itself, if the sector is to recover. We fully concur with this and have no doubt that the ability of the industry to change has been constrained, the speed of change has been low and internal issues concerning alignment of interest and industry collaboration have had an impact on the outcome. Difficulties in aligning the industry and establishing collaboration among all involved parties of the local value chain because of an inability to overcome opposing interests have certainly slowed the pace of change. However, from the industrial development point of view the Asian developmental states and the ability of these governments to undertake such changes, the record of the South African government is rather disappointing. Given the responsibility of the government to undertake economic development and secure employment and income for the population, it is difficult to defend not having a stake in the decline in employment from approx. 300,000 to 120,000 persons over $15-20$ years. The irony here is that the aggregated and sustained impact on the industry lately has made it obvious to the DTI that the downturn in number of employees, number of closures etc, has been too high. This finally led to the promulgation of the 'Rescue Package' in early 2009, including a large number of initiatives that earlier were not considered, or alternatively were considered likely to only have a limited impact (like the skills development issues).

In relation to Rodrik's views, and as noted in the main part of this chapter, the collaboration between the government (the DTI) and the industry has neither been close, constructive nor of mutual benefit. On the contrary, it has deteriorated over time and probably constitutes a major part of the explanation as to why the development has been as outlined above. The political relations have led the relations between government and its alliance partners, including the trade 
unions, to override the economic, industrial conditions. Instead of a constructive tripartite relationship, government and unions have sided against the industry. The losers have - ironically - been the employees and their families, as approximately 150,000 persons have lost their jobs and many of the currently employed are now working in poor conditions in informal businesses.

The South African textiles and clothing industry has experienced internal and external challenges since the mid-I99os, leading to a drop in employment levels to less than half of that in the mid-I980s. While generally being slow to react and having difficulties in aligning with the involved industry parties, some companies have fully adapted to the new competitive environment. Others are still attempting to make the transition, whilst many more have unfortunately been forced to close. Starting out as a formalized, coherent industry in the mid-I99os, the present situation of the industry is marked by a high level of value chain fragmentation and informalization. It is a development that has been affected by the significant changes in the external competitive environment where China has emerged as the textiles and clothing producer of the world. And numerous changes have taken place within international trade policies and frameworks with the GATT being phased out, the WTO being phased in, the ATC/MFA being phased out in 2004 and the AGOA being established in the late ig9os.

To a new and inexperienced government this raised numerous challenges, which the government has not been very successful in handling. Key issues have included a lack of coherence of policies aimed at remedying market failures (at the national government and industry level). Furthermore, while some policies at the national government level (like the EOI with emphasis on macroeconomic stability and so on) carry merit, the lack of understanding of the situation in the industry and accordingly, the unability to implement relevant supporting, timebound measures has been profound. In addition, an increasing lack of government and industry collaboration has compounded the situation. In competition with Asian countries where the governments have gone to lengths to assist the industry (or even as is the case of the aforementioned South African automotive industry), it poses severe challenges for the policies of the government that their decisions to a high degree have been taken without input from industry informants of the textile and clothing industry. The advantage of having the unions involved in the policymaking, as part of a well-functioning tripartite system has not materialized, as the political situation along with the DTI's decreasing capacity has led to a kind of capture of the DTI from the union's side. Or phrased differently: 'the unions won the policy battle, but South Africa lost the industry' - or at least a considerable amount of the employment. ${ }^{17}$ 


\subsection{Concluding remarks and implications for industrial policy}

If we assume that the issue is the alignment of government policies to the strengths and weaknesses of the textiles and clothing industry, relative to Schmitz's framework of 'technology and marketing gaps' (see above), the findings reveal a picture of inadequacy in terms of formulating and implementing appropriate industrial policies. Comparing Schmitz's proposals with the situation in the industry (where both technology and marketing are lacking), it appears government focus would have been better directed in terms of attracting FDI (as in the case of the automotive industry). If we accept the 'gap' to be only related to technology or marketing, then either a focus on securing licensing agreements, joint ventures or integration into global value chains would be the recommended policy. However, the fourth option, an export-oriented strategy, which was followed in the case of the South African industry, is the only option one would not go for - following the logic sequence as laid out by Schmitz (2007). As we outlined above, the South African government has, at face value, actively supported the textile and clothing industry. A closer assessment of this statement however, reveals a number of flaws. The government policies have been based on the basic structure established by the mid-I99os at the macroeconomic level (for example, EOI-strategies and macroeconomic stability), but the policies have not been stringent at the textiles and clothing industry level, failing to address the technology and marketing gaps, and have lacked a sufficient time horizon, often being implemented too late. Using Wad and Jeppesen's typology, the strategy of the South African government mostly resembles a 'laissez-faire strategy'.

While the historical and domestic reasons have been outlined, we also need to assess whether FDI is the magic solution. It has surely been of key importance to the transformation of the South African automotive industry (see for example, Barnes and Morris, 2008), however, other experiences tell us that FDI is not a guarantee for spillovers to domestic firms. And given the situation in the industry, what merits do the other two options carry?

In relation to Schmitz (and Schulpen and Gibbon), a key problem has been the lack of acknowledgment by the government of the size of and historical reliance on the domestic market. The domestic market could and should have been focused on as key to the survival of the textiles and clothing industry in the mid-199os. In the very least, a greater level of foresight would have identified the domestic market as a base on which to rely while changing the focus of the industry and allowing FDI to enter and assist in upgrading, as the situation in the South African automotive industry showed. The domestic market continues to operate as such, as it is still the key market constituting more than $95 \%$ of the industry's total turnover today. A domestic market, which moreover has grown 
since 2005 , and thereby provides extra opportunities for local manufacturers (see below). In addition, the challenges that the textiles and clothing industry faced technological-wise and marketing-wise should have pointed the South African government to any of the policy solutions other than the EOI-strategy adopted. If the EOI was of benefit to other major parts of the South African industry, mediating measures should then have been in place to assist the domestic textiles and clothing industry.

Important to note, though, is that not just any type of FDI would have benefited the South African textiles and clothing industry. As critics of the neoclassical and neo-liberal assumptions of FDI are quick to point out, it is crucial that FDI inflows are linked to the domestic industry in order to be of benefit to the local industry (Sumner, 2005, Rugraff et al,, 2009). Positive spillovers do not happen by themselves: they are the result of conscious efforts by the government seeking to link MNEs and local companies, ensuring deep, intensive and longterm types of collaboration (as Altenburg, 2002; Giroud \& Scott-Kennel, 2006 also have argued). Most of the FDI that has entered South Africa since 1994 has not been of such a kind, but on the contrary 'enclave' investments by Asian firms seeking to exploit the investment incentives provided by the government and low wages. The outcome has been temporary investments; capital that tends to leave as quickly when incentives cease to be offered (to neighboring Lesotho, Swaziland or Namibia or Asian countries like Vietnam and Cambodia), focusing on the bottom rungs of the industry, with no linkages as the government has carried out its 'laissez-faire type of policy'. The government has not even ensured proper enforcement of local legislations (see Bezuidenhout et al., forthcoming).

Similarly, the other policy options argued by Schmitz (either linking up to global value chains if marketing is the issue or promoting joint ventures between local firms and MNEs) entail the development of a proper framework if they are to lead to a positive outcome for the industry. Entering a global value chain requires investigation of which chains - and markets - are considered relevant or needed in terms of supporting the industry with appropriate measures. Skills development is one such form of support, if the local industry needs to improve its ability to add particular features to the products produced or is in need of design capabilities in order to respond to the trends in the foreign markets. Without such government initiatives, any effort will have been wasted, as the local companies risk being locked into global value chains with few options to alter their position. The story regarding the joint venture option resembles the FDI with additional demands attached. The bottom line being that the developing country government needs to have a well thought, flexible policy in place with a long-term vision which it concurrently assesses and adjusts as the industry (and the government) learns from experience. 
If we take the point of departure in Schmitz's framework, what are then the learning points for a developing country's government from the assessment of the development in the South African textiles and clothing industry? We find three learning points: I) time of adjustment to global competition; 2) the obstacles for collaboration between government and industry, and: 3) the importance of the capacity of government. The three points are related, but we will treat them separately for the sake of clarity.

First, a key observation is that the time of adjustment of an industry used to a protected competitive environment to 'global competition' is longer than anticipated (particularly if well formulated supply-side support is missing). This means that there is a need for 'protectionist/supportive policies' for longer than often anticipated. Government is required to respond quickly to industry needs with relevant policies and initiatives. A dividing line is whether the industry is well established and diverse (as the South African textiles and clothing industry was by the mid-1990s) or relatively young, inexperienced and unfocused (as evident in respect of the clothing industry in a number of African countries since 2000 and the initiation of AGOA). If the industry is diverse, then clearly the government will have to make a choice in terms of which party to support. As highlighted by Kaplinsky and Morris, liberalization and free market policies (such as EOI-strategies) are too limited in their scope to provide developing countries looking to sustain their textiles and clothing industries with support (2008).

On the other hand, given the new rules of the game, in particular the competition from China and other Asian countries, the question is whether the technology and marketing gaps have become too large making it nearly impossible for a 'solely' indigenous industry to survive the global competition. Accordingly, how can a developing country government capably attract FDI in a manner that not simply wipes out the domestic industry, but actually brings MNEs in and facilitates linkages, upgrading and so on? This similarly applies to other upgrading routes, whether in the form of a licensing agreement, building on joint ventures (and local content requirements) and/or the linking up to and learning from global value chains.

Secondly, the importance - and difficulty - of government-business collaboration is to be noticed. While the theoretical approaches and the East Asian experiences which, for example, Rodrik refers to, highlight the success of such collaboration, the South African experiences show that this is difficult to achieve. Different historical, political and cultural factors contribute to these difficulties. In particular, various types of mistrust may exist between the government and the business sector, as indicated in the situation in Ghana, Kenya and Uganda, to name but a few examples. While developing country governments are the ones 
that decide whether and how to collaborate with the business sectors, including which parts of the business sector, and need to assess the pros and cons of engaging with business, the importance of this collaboration to economic development, employment and income generation is high.

The third and final point relates to the fact that one cannot underestimate the importance of capacity in government. Yet, the South African approach to this dilemma has been limited to only indirectly providing skills upgrading opportunities in this field. It is an example of diminishing capacity, which - on top of the constrained relationship between government and business - impacts negatively on the ability of government to formulate and implement sufficient policies. Capacity of government includes a thorough understanding of the situation in the industry and an ability to focus on what the industry's development potential is. As mentioned under the first point, a major problem has been the lack of recognition of level of experience of the textiles and clothing industry and its domestic base. Unfortunately, similar developments have taken place in many African countries over the last 20-25 years (Mkandawire, 200I) probably with the same outcome. This points to a future, continued emphasis on building and/or developing capacity of developing country governments, particularly if the successes from Asia are to be repeated.

On an endnote, while the story of the South African textiles and clothing industry since the mid-I990s has mostly been a story of downturns, and the industry is clearly facing a crisis point at present, there is the possibility of an upturn going forward. In the South African case, the present situation is one which requires the resolving of the fracture point that exists between domestic retailers and producers, as well as substantial upgrading of both textiles and clothing capabilities with assistance from government and its ability to successfully implement appropriate policies.

However, in order to compete with Chinese imports, especially in the domestic market, it is essential that South African clothing manufacturers and CMTs are able to differentiate themselves and provide something that the Chinese competitors cannot. The recent emergence of 'lean manufacturing' and 'fast fashion' principles as two such innovations in the industry give the South African manufacturers and CMTs an opportunity to provide the local retailers with short lead times on orders, in-season tradability and other tenets of clothing and textiles manufacturing best practices (Morris and Reed, 2008). There is a need for adaptation to domestic retailer strategies of supplying 'fast fashion', a need to be able to counterbalance the increased uncertainty regarding the Chinese manufacturers and suppliers to the local retailers, and to be able to meet consumer demands for increased fashion variety and increased efficiencies in the manufacturing value chain. That is why it is important to develop a closer link between technology and 
marketing, in order to meet the increasing demand of the retailers. Furthermore, the use of information technology should enable a close alignment of manufacturers' and retailers' value chains (Barnes, 2008).

Making industrial policies work is a challenge, but it is not impossible. Whether the South African case develops into an upturn in the years to come or continues on its downturn will be dependent on numerous factors. The future will tell. Still, it is not too late to make a transformation, which puts more emphasis on the alternatives to the present route, whether FDI, license and joint venture or linking up to global value chains.

\section{Notes}

* B\&M Analysts and School of Development Studies, University of KwaZulu-Natal.

I This includes the industrial policies which are promoted via ODA, and the fact that donors (bi- and multilateral) often play an important role in LDCs. This is where industrial strategies increasingly tend to be formulated along the lines of 'private sector development strategies' (PSDPs) and/or Poverty Reduction Strategy Papers (PRSPs), with reference to the Millennium Development Goals (MDGs)). However, we focus on the interplay between the (developing country) state and the private sector.

2 Interview with Etienne Vlok, SACTWU, October 2008, Cape Town.

3 See for example DTI (2008) 'South Africa's Economic Transformation: A Strategy for Broad-Based Black Economic Empowerment', October, Johannesburg, South Africa.

4 The DCCS benefit is effectively a $14 \%$ to $25 \%$ export incentive for the South African clothing and textiles industry - depending on where firms source their fabrics. If sourced in South Africa the benefit is $25 \%$, but if imported then the benefit reduces on the basis of duties payable on imported fabrics.

5 The benchmarking program undertaken in the two mentioned clusters in Western Cape (consisting of 4I manufacturers and 5 retailers) and Kwazulu-Natal (consisting of 32 manufacturers and 2 retailers) have included focus on: I) Cost control (for example, Stock control), 2) Quality (for example, measured in customers product return and internal defect rate), 3) Value chain flexibility (for example, Logistics capabilities), 4) Value chain reliability, 5) Human resource development, and 6) Product innovation (see Barnes, 2008).

6 See Barnes 2008; 2009.

$7 \quad$ Figures are found in appendix $2 \mathrm{~A}$.

8 To put the decline into a firm perspective, I 3 I clothing firms have shut down in the last three years, mainly due to increased import penetration of Chinese products, while illegal imports have served to exacerbate the problem.

9 The associated socioeconomic effects for the country if employment levels are allowed to continue their decline are substantial, with this percentage decline equating an annual loss of over I0,000 jobs from the textiles and clothing industry since 2000 (IDC, 2009).

Io Figures are found in appendix $2 \mathrm{~B}$.

I I Jack Kipling, Executive Director, Clotrade, I 3 Oct 2008. 
I2 For example, I0-I 2 different persons being in charge of the textiles and clothing desk, according to Jack Kipling, Executive Director of Clotrade, I 3 November 2008.

I3 The information that we have acquired on this topic is somewhat limited, as several of the stakeholders have refrained from commenting. However, on the other hand, others like the trade unions and Clotrade have been straightforward and outspoken.

I4 One of the downsides of this was the poor conditions that the workers faced (poor working conditions, low wages, poor treatment from management and little space to voice critique).

I5 Eventually, only the activities concerning the Country of Origin labelling and the preface of the Replacement for the DCCS have been undertaken. And the latter, still not decided.

I6 To paraphrase the former president of the Danish National Labor Organisation (LO) Mr. Thomas Nielsen, when he concluded the achievements of the National Labor Movements and stepped down as president.

\section{List of references}

Altenburg T. (2002)'Transnational Corporations and Development of Local firms', in T. Narp and S. Jeppesen (ed.) The Partners in Development, Report from the FAU Conference 2002, March 7-9, Gjerrild, Denmark, FAU, Copenhagen.

Altenburg T. and C. von Drachenfels (2006) 'The 'New Minimalist Approach' to Private-Sector Development: A Critical Assessment', Development Policy Review 24(4), 387-4II.

Amsden A. (1989) Asia's Next Giant: South Korea and Late Industrialization, Oxford University Press, Oxford.

Barnes J., R. Stewart and D. Finlayson (2007) KwaZulu-Natal Clothing and Textile Industry Report, Research report compiled for Trade and Investment KwaZulu-Natal, January.

Barnes J. (2008) The South African Clothing Industry's Competitiveness Progress from 2005 to 2008: Lessons for Edcon, Firm Level Competitiveness Findings from the Cape and KwaZulu-Natal Clothing and Textile Clusters' 2008 Database, Report compiled for Edcon, Benchmarking and Manufacturing Analysts SA (Pty) Ltd, Hillcrest, South Africa.

Barnes J. (2009) Fast Fashion, Lean Retailing and Associated Supply Chain Management Principles and Practices. Evidence of Best Practices Adherence at South African Retailers: The 2008 Findings, Report to the Cape and KwaZulu-Natal Clothing and Textile Clusters, Benchmarking and Manufacturing Analysts SA (Pty) Ltd, Hillcrest, South Africa.

Barnes J. and M. Morris (2008) 'Staying Slive in the Global Automotive Industry: What Can Developing Economies Learn from South Africa about Linking into Global Automotive Value Chains?', European Journal of Development Research $20(\mathrm{I}), 3 \mathrm{I}-55$. 
Bethlehem L. and M. Goldblatt (eds.) (1997) The Bottom Line. Industry and Environment in South Africa, University of Cape Town Press, Cape Town.

Bezuidenhout A., S. Jeppesen and V. Winterfeldt (Forthcoming) More Than a Fashion? Codes of Conduct and their Impact on the Working Conditions in the Textiles and Clothing Industry in Southern Africa, University of Kwazulu-Natal Press, Durban.

Blomström M., A. Kokko and M. Zejan (200o) Foreign Direct Investment, Firm and country strategies, MacMillan, Basingstoke.

Clotrade (2007) Report and Analysis on the impact of Quotas, Clotrade, Cape Town.

Clotrade (2008a) Analysis of Exports of Apparel for the Year January to December 2007, Clotrade.

Clotrade (2008b) Analysis of Apparel Imports January-December 2007, Clotrade.

Department of Finance (1996) Growth, Employment and Redistribution Strategy, Republic of South Africa, Pretoria, www.info.gov.za/otherdocs/1996/gear. pdf (Last access: December 2006).

Department of Trade and Industry (2007) Industrial Policy Action Plan, Republic of South Africa, July.

Evans P. (1998) 'Transferable Lessons? Re-examining the Institutional Prerequisites of East Asian Economic Policies', Journal of Development Studies 34(6), 66-86.

Fine B. and Z. Rustomjee (1995) The Political Economy of South Africa. From Minerals-Energy Complex to Industrialisation, Hurst and Company, London.

Gereffi G. (1994)'The Organization of Buyer Driven Global Commodity Chains. How US-Retailers Shape Overseas production Networks', in G. Gereffi and M. Korzeneiewicz (eds.) Commodity Chains and Global Capitalism, Greenwood Press, USA.

Gereffi G. (I999) 'International Trade and Industrial Upgrading in the Apparel Commodity Chain', Journal of International Economics 48(I), 37-70.

Gereffi G., J. Humphrey and T. Sturgeon (2005) 'The Governance of Global Value Chains', Review of International Political Economy II(I), 78-104.

Giroud A. and J. Scott-Kennel (2006) 'Foreign-Local Linkages in International Business: A Review and Extension of the Literature', Working Paper Series 06/06, Bradford University School of Management, http://www.brad.ac.uk/ management/external/pdf/workingpapers/2006/Booklet_o6-06.pdf

Government of South Africa (1994)'White Paper: Reconstruction and Development Programme', Government Gazette 353/ı6085, Cape Town.

Hirschsohn P., S. Godfrey and J. Maree (2000) Industrial Policy-Making in the Auto, Textile and Clothing Sectors, Transformation 4I, 55-88. 
Humphrey J. and H. Schmitz (2004) 'How Does Insertion in Global Value Chains Affect Upgrading in Industrial Clusters?', Regional Studies 36(9), Ior7I027.

IDC (2009) Textiles and Clothing Prospects, Pretoria.

International Trade Administration Commission of South Africa (2004) Guidelines, Rules and Conditions to the Duty Credit Certificate Scheme, January, Pretoria.

International Trade Administration Commission (2006) Import Restrictions on Textiles and Clothing Originating from the People's Republic of China, Department of Trade and Industry, No. R.I056, 20 October 2006.

Jeppesen S. and J. Barnes (Forthcoming) 'Industrial Development Policy and Firm responses. The South African textiles and clothing industry', CBDS Working paper, Centre for Business and Development Studies, CBS, Copenhagen.

Joffe A., D. Kaplan, R. Kaplinsky and D. Lewis (1995) Improving Manufacturing Performance in South Africa. Report of the Industrial Strategy project, Industrial Strategy Project, International Development Research Centre, University of Cape Town Press, Cape Town.

Lall S. (1990) Building Industrial Competitiveness in Developing Countries, OECD Development Centre, Paris.

Marais H. (200I) South Africa. Limits to Change. The Political Economy of Transition, 2nd Edition, University of Cape Town Press, Cape Town.

Mathews J. (2006) 'Dragon Multinationals: New Players in 2ist-Century Globalization', Asia Pacific Journal of Management 23, 5-27.

McCormick D. and P.O. Pedersen (eds.) (1996) Small Enterprises: Flexibility and Networking in an African Context, Longhorn, Kenya.

Mkandawire T. (200I) 'Thinking about Developmental States in Africa', Cambridge Journal of Economics 25, 289-313.

Morris M. and L. Reed (2008) 'Review of the Impact of the China Restraint Agreement on the Clothing and Textile Industry in South Africa', PRISM School of Economics, University of Cape Town.

Nadvi K. and H. Schmitz (1994) 'Industrial Clusters in Less Developed Countries: Review of Experiences and Research Agenda', IDS Discussion Paper 339, Institute of Development Studies, University of Brighton, Brighton.

Padaychree V. (2009) 'Development Issues for the Future: A South African Perspective', European Journal of Development Research $2 \mathrm{I}(\mathrm{I}),{ }_{15-20}$.

Rodrik D. (2004) 'Industrial Policy for the Twenty-First Century', http://www. ksg.harvard.edu/rodrik (Last access: November 2008).

Rugraff, E., D. Sanchez-Ancochea and A. Sumner (eds.) (2009) Transnational Corporations and Development Policy. Critical Perspectives, Palgrave MacMillan, Hampshire. 
Schmitz H. (2007) 'Reducing Complexity in the Industrial Policy Debate', Development Policy Review 25(4), 417-428.

Schulpen L. and P. Gibbon (2002) 'Private Sector Development: Policy, Practice and Problems', World Development 30(I), I-15.

Sumner A. (2005) 'Is Foreign Direct Investment Good for the Poor? A Review and a Stocktake', Development in Practice 15 (3-4), 269-285.

The Presidency (2007) The Accelerated Strategy for Growth and Innovation in South Africa. A Summary, Republic of South Africa, Pretoria (www.info. gov.za/asgisa) (Last access: May 2009).

UNCTAD (200I) World Investment Report 2001. Promoting Linkages, United Nations, New York.

UNCTAD (2008) World Investment Report 2008, United Nations, New York.

Van Horen C. (1997) 'Cheap Energy - At What Cost? Externalities in South Africa's Electricity Sector', in L. Bethlehem and M. Goldblatt (eds) The Bottom Line. Industry and Environment in South Africa, 30-69, University of Cape Town Press, Cape Town.

Wad P. and S. Jeppesen (2006) 'Development Strategy, Industrial Policy and Cross Border Inter-firm Linkages', in M.W. Hansen and H. SchaumburgMüller (eds.) Transnational Corporations and Local Firms in Developing Countries - Linkages and Upgrading, 3II-338, Copenhagen Business School Press, Copenhagen.

Wade R. (2003) 'What Strategies are Viable for Developing Countries Today? The World Trade Organization and the Shrinking of 'Development Space,' Review of International Political Economy Io(4), 62I-644.

Weiss L. (ed.) (1993) States in the Global Economy. Bringing domestic institutions back in, Cambridge University Press, Cambridge. 


\section{Appendixes}

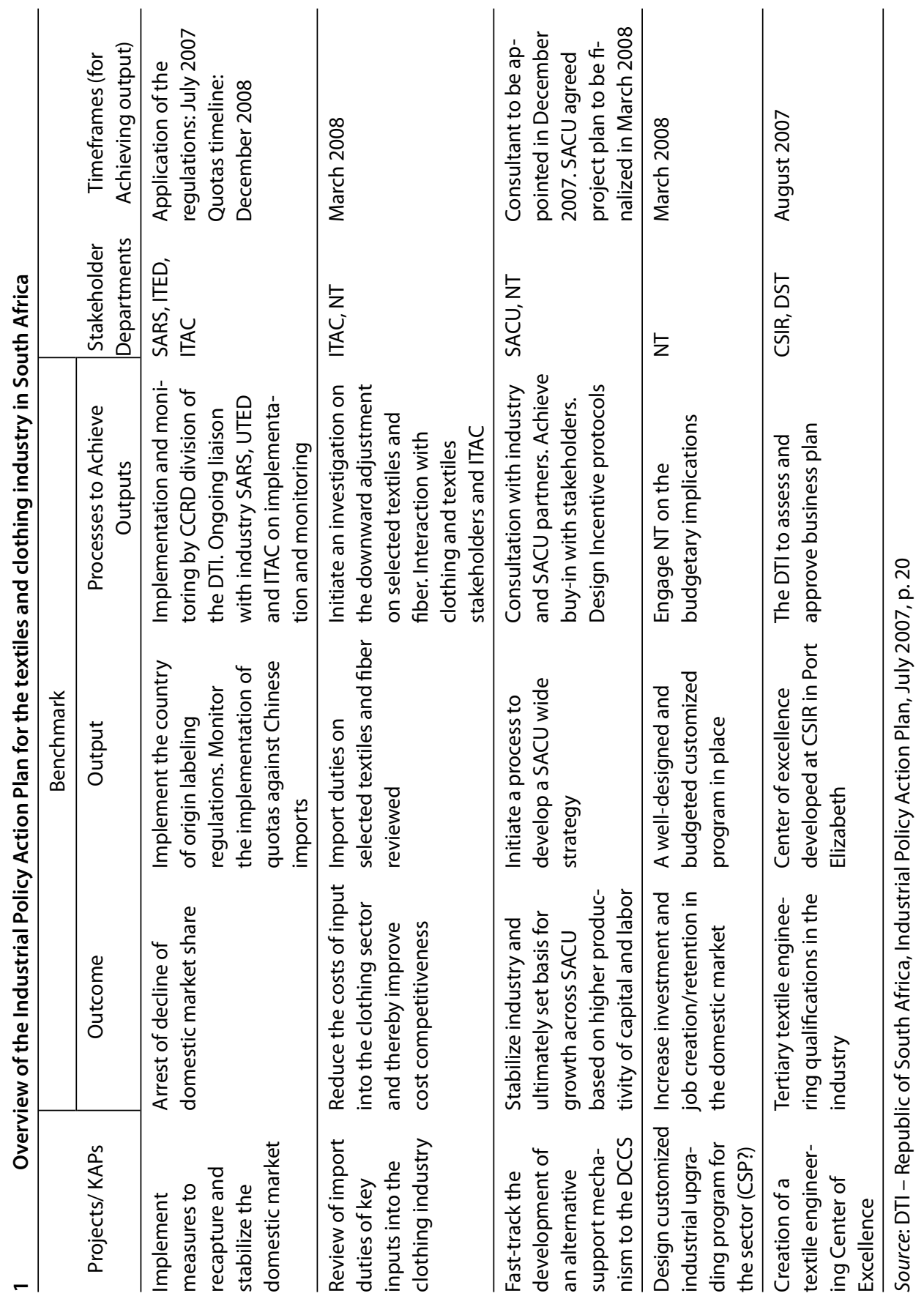


Table A Production performance of the South African industries since 1998 (index $2000=100$ )

\begin{tabular}{lccccccccccc}
\hline & 1998 & 1999 & 2000 & 2001 & 2002 & 2003 & 2004 & 2005 & 2006 & 2007 & 2008 \\
\hline Textiles & 104.7 & 99.1 & 100.0 & 102.0 & 110.4 & 93.1 & 92.7 & 81.3 & 80.6 & 80.0 & 73.5 \\
\hline $\begin{array}{l}\text { Other textile } \\
\text { products }\end{array}$ & 94.9 & 96.0 & 100.0 & 104.3 & 113.7 & 102.2 & 109.6 & 117.0 & 120.5 & 119.5 & 116.4 \\
\hline $\begin{array}{l}\text { Knitted, } \\
\text { crocheted } \\
\text { articles }\end{array}$ & 113.2 & 111.6 & 100.0 & 103.4 & 111.2 & 99.2 & 100.3 & 77.4 & 80.7 & 82.6 & 86.7 \\
\hline $\begin{array}{l}\text { Wearing } \\
\text { apparel }\end{array}$ & 104.4 & 105.9 & 100.0 & 94.4 & 100.5 & 99.2 & 104.8 & 103.9 & 106.7 & 113.8 & 114.9 \\
\hline
\end{tabular}

$\begin{array}{llllllllllll}\text { Total averaged } & 104.3 & 103.2 & 100.0 & 101.0 & 108.9 & 98.4 & 101.9 & 94.9 & 97.1 & 99.0 & 97.9\end{array}$ index

\begin{tabular}{llllllllllll}
\hline CPI-adjusted & 184.9 & 174.0 & 160.0 & 152.9 & 151.1 & 129.0 & 131.6 & 118.6 & 116.0 & 110.3 & 97.9
\end{tabular}

Source: Statistics South Africa data, adjusted for inflation (www.statssa.gov.za)

Table B Actual and real sales values (ZAR thousands)

\begin{tabular}{|c|c|c|c|c|c|c|c|c|c|c|c|}
\hline & 1998 & 1999 & 2000 & 2001 & 2002 & 2003 & 2004 & 2005 & 2006 & 2007 & 2008 \\
\hline Apparel & 1494525 & 1655359 & 1366077 & 1447041 & 1426186 & 1387066 & 1602035 & 1324474 & 1357786 & 1476142 & 1275054 \\
\hline Textiles & 876956 & 930437 & 802805 & 849874 & 1017883 & 813072 & 734364 & 634163 & 691087 & 590778 & 568090 \\
\hline $\begin{array}{l}\text { Other } \\
\text { textile } \\
\text { products }\end{array}$ & 804090 & 940619 & 923742 & 909097 & 939333 & 880641 & 1036307 & 968210 & 1001266 & 919373 & 833494 \\
\hline $\begin{array}{l}\text { Knitted, } \\
\text { crocheted } \\
\text { articles }\end{array}$ & 252431 & 274061 & 214776 & 252666 & 331112 & 224894 & 189521 & 194016 & 187939 & 163283 & 171451 \\
\hline $\begin{array}{l}\text { Total (CPI- } \\
\text { adjusted) }\end{array}$ & 447572.4 & 462159.7 & 343641.6 & 382247.6 & 459240.4 & 294749.46 & 244858.7 & 242520. & 224538.91 & $\begin{array}{c}182032 . \\
5152\end{array}$ & 171451 \\
\hline
\end{tabular}

Source: Textiles Sector Prospects, IDC, 2009 


\section{About the authors}

Katalin Antalóczy is college Professor/head of Department of Business Administration at the College for Modern Business Studies from 2007, and senior research fellow at the Financial Research Ltd Budapest from 1988. She obtained her PhD from the Hungarian Academy of Science in 1994. Her research activity is focused on the Globalization, Foreign Direct Investment and Foreign Trade.

Justin Barnes is the Chairman of a benchmarking and cluster facilitation company in South Africa, B\&M Analysts, as well as an Adjunct Associate Professor of Industrial Studies at the University of KwaZulu-Natal. Justin has worked primarily in the automotive and clothing and textiles industries over the last 15 years, both in South Africa and internationally. He has been responsible for compiling numerous local, regional and national industrial policies relating to these sectors over that time, and has also written a number of articles and book chapters on industrial policy issues more broadly. His primary academic interests relate to global value chains, regional and national industrial development, and firm-level and supply chain upgrading, particularly as these relate to emerging economies broadly, and Sub-Saharan Africa more specifically.

Delane Botelho is Associate Professor in International Marketing at São Paulo Business Administration School of Fundação Getulio Vargas (FGV-EAESP, Brazil), where he also obtained his doctoral degree in Business Administration. Before joining EAESP, he was assistant and associate professor in Marketing at the Brazilian School of Public and Business Administration (FGV-EBAPE), Rio de Janeiro. He was visiting scholar at Marshall School of Business, University of Southern California (USA) and research fellow at United Nations Conference on Trade and Development (UNCTAD). He participated in the first MGG (Managing Global Governance) program at the Deutsches Institut für Entwicklungspolitik (Germany). He has published internationally and participated in 
several conferences abroad. His research interests include macromarketing and implications of Marketing for regional development in emerging markets.

Chiara Franco is a post-doc research fellow at the University of Bologna since 2009. Her research activities focus on International Economics, especially FDI, and economics of innovation. She has a Bachelor's degree in Political Science, a Master's in Development Economics and Innovation and $\mathrm{PhD}$ in Law and Economics, all from the University of Bologna (Italy). She has been a visiting scholar at the SPRU (Science Policy Research Unit), University of Sussex, over the years 2008-2009.

Michael Wendelboe Hansen is Associate Professor in International Business at the Center for Business and Development Studies, Copenhagen Business School. His main research interest is related to MNC strategy and organization in developing countries, in particular India, and he has done extensive research on the linkage strategies of MNCs in developing countries.

Soeren Jeppesen is an Associate Professor at the Center for Business and Development Studies, Department of Intercultural Communication and Management, Copenhagen Business School, Denmark. He has worked on a range of issues relating to industrial development in Southern Africa, and in particular South Africa since 1998. His research interests include competitiveness and upgrading of developing country firms, strategies of developing country firms (with particular reference to the textiles and clothing industry in Southern Africa), CSR and SMEs, Youth, employment and entrepreneurship in African economies (Zambia, Uganda and Ghana).

Črt Kostevc is Assistant Professor of International Economics and has been employed at the Faculty of Economics, University of Ljubljana (FELU) since 2000. In 2003 he has obtained a Master's degree from the London School of Economics and a doctorate in Economics at FELU in 2005. Since joining FELU he has been a member of a number of international research syndicates in the Phare initiative as well as $6^{\text {th }}$ and $7^{\text {th }}$ Framework project of the European Union. In his capacity as a researcher he has also been involved in a number of research and consultancy projects related to international trade, innovation, productivity analysis in South-Eastern Europe and beyond. His work has been published in several peer reviewed international journals and has lectured (visiting lecturer) in Austria and Italy. He is a member of the European trade study group (ETSG) and International study group on exports and productivity (ISGEP). 
Kornelia Kozovska has been working as a policy analyst and researcher at the European Commission since 2008. Her research activities have focused on regional economics and development, competitiveness measures, labor economics and economics of education. She is a co-author of the first EU Regional Competitiveness Index (RCI) which came out in 2010 and has published on topics related to regional clusters and firm performance, employability and transition from education to work. She has a Bachelor's degree in Political Science from Bryn Mawr College (USA), a Master's in Development Economics and Innovation and a PhD in Law and Economics, both from the University of Bologna (Italy).

Mike Pfister is an international economist, currently at the Organisation for Economic Co-operation and Development (OECD). He previously worked for the United Nations Conference on Trade and Development (UNCTAD), as well as for consulting groups in the field of SME and investment policies and promotion. His work has covered Asia, Africa and Brazil.

Tjaša Redek is Assistant Professor at the Faculty of Economics, University of Ljubljana. She studied at FELU and at London School of Economics. She has been employed at FELU since 1999. Her research work focuses on topics from the field of economic growth and development, especially the link between institutions (especially labor market), competitiveness and development. Currently she also studies environmental issues and their current and future implications for growth. She has been also involved in several national and international research projects. The research work has resulted also in journal publications and books. She teaches Macroeconomics at an intermediate level, Emerging market economics and Economics of transition.

Matija Rojec is Research Professor at Faculty of Social Sciences, University of Ljubljana, and at the Center for International Relations of Faculty of Social Sciences, and Secretary at the Institute of the Republic of Slovenia for Macroeconomic Analysis and Development. His areas of expertise include FDI, transition economics, European integration, enterprise restructuring, innovation and technology transfer. He published books and numerous articles with journals like World Development, Transnational Corporations, Management International Review, Eastern European Economics, Post Communist Economies, Economic Systems, Industry and Innovation, International Relations and Development, Journal of East-West Business, Prague Economic Papers, Journal of East-West Economics and Business, Applied Economics Quarterly, Structural Change and Economic Dynamics, Ekonomicky casopis etc. M. Rojec coordinated and partici- 
pated in more than 25 international research projects. He has been consultant to various ministries and agencies of Slovenian government in various occasions related to FDI, EU, OECD and WTO accession processes. Recently he has been involved in South Eastern Europe in the field of FDI, transition strategies and EU integration processes.

Eric Rugraff is Associate Professor in International Economics at the University of Strasbourg and researcher at the Bureau d'Economie Théorique et Appliquée (BETA). His research concentrates on Transition economics and strategy of multinational corporations. He is co-convener of the European Association of Development Research and Training Institutes (EADI)-Working Group 'Transnational Corporations and Development'. He published books and numerous articles in international journals.

Magdolna Sass is a senior research fellow at the Institute for Economics of the Hungarian Academy of Sciences. She graduated from the University of Economics in 1988, and worked for the Institute for World Economics of the Hungarian Academy of Sciences until 1995. Then she joined the Institute of Economics. She obtained her PhD from the Hungarian Academy of Sciences in 1998. Between 1997 and 2000, she worked for the Organisation for Economic Cooperation and Development (OECD) in Paris. On return to Hungary she continued to work on the topics of foreign direct investments and foreign trade and related policies in the East-Central European countries, with special attention to developments in Hungary. Her present research was supported by the Hungarian research fund, OTKA (68435).

Miklós Szanyi (DSc) is research adviser of the Institute of World Economy of the Hungarian Academy of Sciences, and Professor of the University of Debrecen. His main research interest is comparative analysis of market economic institutions of transition economies as well as corporate performance and the role of multinational corporate networks in the modernization process of these countries. Miklós Szanyi is author of two books, several book chapters and over 150 scientific publications in leading Hungarian and foreign journals.

Tulus Tambunan is Professor of Economics at the Faculty of Economics, University of Trisakti, Jakarta. Currently he is also director of the Center of Industry, SME and the Business Competition Studies at the same university. His interest of research areas are particularly industrialization, small and medium enterprises (SMEs), poverty, and economic crisis. In the past few years he has published several books including Economic Crisis and Vulnerability: The Story from Southeast 
Asia (New York: Nova Science Publisher, 20II, forthcoming), Trade Liberalisation and SMEs in ASEAN (New York: Nova Science Publisher, 2010), SMEs in Asian Developing Countries (New York: Palgrave Macmillan, 2009).

Osmund Osinachi Uzor holds a $\mathrm{PhD}$ degree in Economics from the University of Bremen. Presently, he is research Associate in microeconomics of development at the Institute for World Economics and International Management (IWIM), University of Bremen, Researcher on African development in Bremen. His research interests cover economic development policies with special emphasis on industrialization policy, trade policy, supply and value chains, labor market in Africa and pro-poor development theory. 



\section{Index}

absorptive capacity $\mathrm{I} 3,20,28,4 \mathrm{I}, 47,78,89$, $93, \mathrm{I} 23, \mathrm{I} 30-\mathrm{I} 32, \mathrm{I} 35, \mathrm{I} 39, \mathrm{I} 43,225$

bargaining power $16,23,247$ BNDES (Brazilian Development Bank) 218,227

Brazil 36-37, 95, 108, 120, 21I-212, 216-221, $224,227-228,234$

business services $27,32,38,5 \mathrm{I}-59,62,64,67$, 70, 72, I7 $1-172$

capabilities I7, 28-29, 33, 77-78, 8I, 93, 97-98, IOI-IO2, IO5, IO8, IIO, II6-II7, I2O, I 43-I44, I59, I6I-I62, I66, I95, 213-2I5, 223, 234, $246,257,259-260$

captive offshoring $52-53$

Central Java $75,79,97-98$

cluster initiatives $\mathrm{I3}, 2 \mathrm{I} 3,2 \mathrm{I} 5,235,243,25 \mathrm{I}$

comparative advantage(s) 2I, 23, 56, 70, 8I, IIO, I66, I83, 236

competitiveness $42,47,62,72-73,75,91$, IO2, IO7, IIO-III, II3, II9-I20, I42, I59, I69, I7I, I74, I78, 204, 206, 218-219, 224, 232, 242$247,250-25 \mathrm{I}, 26 \mathrm{I}, 263,265$

Croatia I56, I67-I68, I7 I, I73

crowding-in $2 \mathrm{I}, 30$

crowding-out 2I-22, 58, 64

Czech Republic 26, 40, 6I, 69, I25, I28, I3I, I56, I62-I64, I67-I73, I82-I88, I96, 205, 208

developmental impact 3I, 39, 214

distributors $17,20-21,26,216,228$ economic development I3-I5, I9-20, 37, 4046, 96-97, I04, I23-I24, I44, 2II-212, 217 , $234-235,254,259$

economic growth $25,27,41,43,45,97,105$, II4, 2II, 2I4, 24I

Electrolux-Lehel 196, 199, 206

embedded 23, 38, II8, I6I, I72, 203-204, 214 embeddedness 32, 38, I6I, 204, 214

enclaves 30,78

entrepreneurs $33,40,57,92,97,102$, III-II , I69, I7 I, I92

equity participation 193

Estonia I56, I62, I67, I69, I72-I73, I75, I82-

I 83

export-orientation (of MNCs) I8, 24I, 247 export-oriented 37, 59, 6I-62, 64, 67-68, I6I, I63, I65-I66, I72, I88-I90, 232, 242, 256

financial sector $\mathrm{I} 85$ first-tier suppliers 192

global commodity chains I02, I04, I06, 262 global value chains $3 \mathrm{I}-38,43,46$, IOI, IO4IO7, II6-I2O, 215, 227, 232, 235, 237, 256$258,260,262-263$

government policy $28,113,209,224$

Greenfield investment I76, I99, 205 grants 68, I59-I6I, I65, I68-I70, I84

\section{horizontal}

FDI 57, 6I, 63, 70

linkages 20-2I, 205, 213

spillovers I7-I 8, 26 
human capital $37,39,78$, II 7, I27, I40

human capital stock III

Hungary 26, 32, 35, 37-38, 51-73, I25, I56, I62, I64, I67, I7 I-I76, I8I-207

incentive(s)

behavioral $156,159,163,167$

financial $155,158-160,165,170,188,190$, 218

fiscal 94, I58-I59, I6I, I65, I77, I85, I90, 208

locational 159,163

policy/policies 34, I55-156, I58-163, I65, I67, 173-174, 204

$\operatorname{tax} 132,167,176,206,211,224-225$

industrial free trade zones (IFTZs) I88-I89

industrial parks 35, I7 I-172, I75, I90

industrial policy/policies $98,178,188,190$, $212,224-226,232-233,236-237,240,242$,

$247,256,260,262-265$

innovation 28, 4I, 46, 7I, 84, 88, 96, 98-99, IO7-IO8, III, II3, II6-II7, II9, I2I, I40-I44, I68, 170-174, I77-I78, I93, 2II, 213, 228, 236, 240, 259-260, 264

integrator firms 193,195

Inti $32,37-38,8 \mathrm{I}-95$

investment

attraction 220, 225

location 34, I44, I55-157, 173, I76, I89 policy/policies 34, I55, I84-I85, I87-I88, 195, 208

promotion agencies $36,162,166-167,207$, 2II, 225

requirements $\mathrm{I} 88$

Japan 33, 38, 44, 76-79, 83, 95-97, I43-I44, I65-I66, I77, 194, 200-20I

joint venture(s) 19-20, 36-37, 6I, 78, IOI, II4, I64, I82, 213-2I4, 232, 237, 256-258, 260

knowledge $17,23-24,27-29,36,44,56,58$ $60,63-64,66,68,70,73,76,78,87-98$, IO5-IO6, II 4, II7-II 8, I23-I24, I28-I29, I3II32, I35, I40, I44, I55, I58-159, I6I, I64, I67, I7I, I74, 2II, 215, 22I-222, 225, 228, 235-237, 240, 247, 253

diffusion 23, 89-90, 117

Komatsu 33, 38, 83, 88, 95 large enterprises (LEs) 76, 94, 219

linkage effects 43,158

managerial expertise I9I

manufacturing sector $44,55,114,127,133$, I68, I83, 203, 216

Most Favored Nation (MFN) IIO

networks I4, 24, 33, 52, 73, 77, 89-90, IOIIO2, IO4-IO7, I13, II7-II 8, I20-I2I, I28, I3I, I9I-I94, 262

Nokia Komarom 199-20I

offshore outsourcing $32,52-56,70,72$

OLI paradigm 42, 126-I28

Ordinary Brand Manufacturing (OBM) 107

Ordinary Design Manufacturing (ODM) 107

Ordinary Equipment Manufacturing (OEM) 107, 195

ownership advantage(s) I9, 23, I28, I40

parks

industrial $35, \mathrm{I} 7 \mathrm{I}-\mathrm{I} 72, \mathrm{I} 75, \mathrm{I} 90$

science 159, I7 I

technology/technological I7I-I73

performance requirements $160,177,188$

plasma 32, 82-83, 87-95

Poland 26, 34, 38, 53, 69, I24-I26, I28, I32I34, I37-I40, I45-I47, I5I, I62, I64, I8I, I83, I87, 196

privatization $\mathrm{I} 9,35, \mathrm{I} 56, \mathrm{I} 76, \mathrm{I} 82-\mathrm{I} 87, \mathrm{I} 96$, 198, 204-206, 209, 240-24I

privatization-related FDI I86-187, 205

Projeto vínculos 212, 220-223, 226-227

PT Astra International 77

$\mathrm{R} \& \mathrm{D}$ 19-20, 31, 35, 45, 47, 52, 78, 89, I28, I30-I38, I40, I43-I49, I56, I59-I6I, I63, I67I74, 177, 188, 190, 193, 207, 214, 216

reverse spillovers 34, I24, I28-I29, I3I-I32, I37-I38, I 42, I 46-I 49

Romania 34, 38, 53, 56, 66, 69, 72, I24-I28, I32-I34, I37-I40, I43, I45, I48-I50, I56, I62, I67, I69, I72-173 
SEBRAE (Brazilian Micro and Small

Business Support Service) 218-227

Slovakia/Slovak Republic 68, I25, I56, I62, I67, I70, I73, I83, I86, I88, I96, I99, 202

Slovenia 26, I25, 156, I62, I67, I70, 172-173, I75, I79, I8I

South Africa 33, 36-37, 101, 215, 227, 23I267

state-owned companies I86

subcontractor/subcontracting $16-17,20,33$,

$37,76-96,98$, IOI, IO3, II 4, II6, 213

subsidies 29, I59, I61, I65-I66, I68-I69, I75

supplier

contracts 199

development programs 35, 195, 212, 215,

221

promotion policies 191

training program 220, 224

tax allowances 52, 185, 205

tax holidays I59, I85-186 technology transfer $25,31,33,37,40-42,47$, $58,63-64,75-79,82,84,88-89,93-94,96-$ 98, I4I-I42, I63, I67, I7 I, 206-207, 215-2I6, 22I-222, 225-226, 228

Tegal metalworking industry $23,33,75$, 79-83, 90

upgrading I4, 20, 30-3I, 33, 34, 37-39, 42-43, 64, 79, 88, 92, 98, IOI-I2O, I65, I9I, I99, 228, 235, 256, 258-259, 262-264

UPT 89,92

value chains I5, 3I, 33, 35-36, 38, 43, 46, IOI, IO4-IO6, II7, II9-I2I, 215, 227, 232, 235, 237, 256-263

vertical

FDI $69-70$

linkages $43,123,198,213,228$

spillovers I7, 26, 42, I28, I4I, 207

workshop $32-33,38,8 \mathrm{I}-97, \mathrm{IIO}, \mathrm{I7} 8$ 

- the European Association of Development Research and Training Institutes - is the leading professional network for development and regional studies in Europe (www.eadi.org).

PREVIOUSLY PUBLISHED

Andrew Mold (ed.): EU Development Policy in a Changing World: Challenges for the 21st Century (2007) ISBN 9789053569764

Gordon Crawford \& Christof Hartmann (eds.): Decentralisation in Africa: A Pathway out of Poverty and Conflict? (2008) ISBN 9789053569344

Meine Pieter van Dijk (ed.): The New Presence of China in Africa (2009) ISBN 9789089641366

Paul Hoebink (ed.): European Development Cooperation: In Between the Local and the Global (2010)

ISBN 9789089642257 
Multinational Corporations and Local Firms in Emerging Economies aims at contributing to the emerging literature on multinational corporation (MNC)local firm interfaces by providing a number of country studies from emerging economies of the spillover and linkage effects of multinational corporations on local firms. Moreover, the book takes the issue to the policy level by sharing and evaluating policy experiences from a number of countries on efforts to promote closer interaction between MNCs and local firms. The country studies are placed within a framework for analyzing MNC-local firm interfaces that integrates insights from the spillover and linkage literature.

The book's primary market is postgraduate students and researchers in economics, business studies, international relations, political science, development studies and area studies. However, because the book has a policy orientation, development practitioners and policy makers may also find insights and analyses that may inspire efforts to enhance spillover effects of multinational corporations in emerging economies.

Eric Rugraff is Associate Professor at the University of Strasbourg, France. Michael W. Hansen is Associate Professor at the Copenhagen Business School, Denmark.
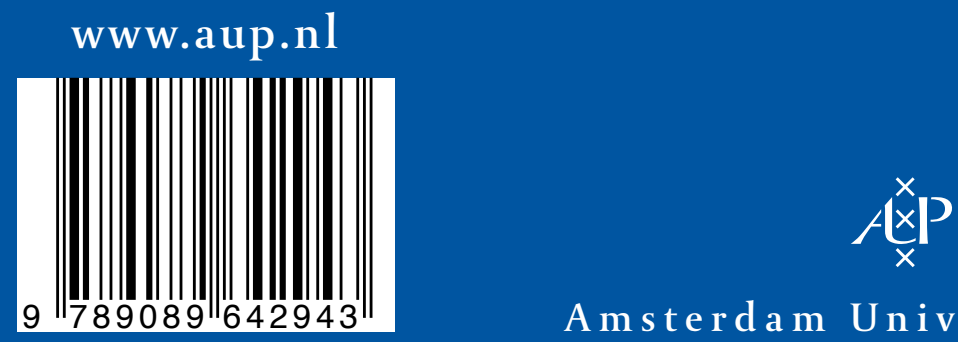

Amsterdam University Press 